US Army Corps

of Engineers 。

Prepared for the U.S. Army Corps of Engineers, Walla Walla District, under an Interagency Agreement with the U.S. Department of Energy Contract DE-AC05-76RL01830

\title{
Passage Distribution and Federal Columbia River Power System Survival for Steelhead Kelts Tagged Above and at Lower Granite Dam, Year 2
}

\section{Final Report}

AH Colotelo

RA Harnish

BW Jones

AC Hanson

DM Trott

MJ Greiner

GA McMichael
KD Ham

ZD Deng

RS Brown

MA Weiland

$X$ Li

$\mathrm{T} \mathrm{Fu}$

December 2014 


\title{
DISCLAIMER
}

This report was prepared as an account of work sponsored by an agency of the United States Government. Neither the United States Government nor any agency thereof, nor Battelle Memorial Institute, nor any of their employees, makes any warranty, express or implied, or assumes any legal liability or responsibility for the accuracy, completeness, or usefulness of any information, apparatus, product, or process disclosed, or represents that its use would not infringe privately owned rights. Reference herein to any specific commercial product, process, or service by trade name, trademark, manufacturer, or otherwise does not necessarily constitute or imply its endorsement, recommendation, or favoring by the United States Government or any agency thereof, or Battelle Memorial Institute. The views and opinions of authors expressed herein do not necessarily state or reflect those of the United States Government or any agency thereof.

\author{
PACIFIC NORTHWEST NATIONAL LABORATORY \\ operated by \\ BATTELLE \\ for the \\ UNITED STATES DEPARTMENT OF ENERGY \\ under Contract DE-AC05-76RL01830 \\ Printed in the United States of America \\ Available to DOE and DOE contractors from the \\ Office of Scientific and Technical Information, \\ P.O. Box 62, Oak Ridge, TN 37831-0062; \\ ph: (865) 576-8401 \\ fax: $(865) 576-5728$ \\ email: reports@adonis.osti.gov \\ Available to the public from the National Technical Information Service \\ 5301 Shawnee Rd., Alexandria, VA 22312 \\ ph: (800) 553-NTIS (6847) \\ email: orders@ntis.gov <http://www.ntis.gov/about/form.aspx> \\ Online ordering: http://www.ntis.gov
}

This document was printed on recycled paper. 


\section{Passage Distribution and Federal Columbia River Power System Survival for Steelhead Kelts Tagged Above and at Lower Granite Dam, Year 2}

\section{Final Report}

$\begin{array}{ll}\text { AH Colotelo } & \text { KD Ham } \\ \text { RA Harnish } & \text { ZD Deng } \\ \text { BW Jones } & \text { RS Brown } \\ \text { AC Hanson } & \text { MA Weiland } \\ \text { DM Trott } & \text { X Li } \\ \text { MJ Greiner } & \text { T Fu } \\ \text { GA McMichael } & \end{array}$

December 2014

Prepared for

the U.S. Army Corps of Engineers, Walla Walla District, under an Interagency Agreement with the

U.S. Department of Energy

Contract DE-AC05-76RL01830

Pacific Northwest National Laboratory

Richland, Washington 99352 


\section{Preface}

The study reported herein was funded as part of the Anadromous Fish Evaluation Program (AFEP), which is managed by the U.S. Army Corps of Engineers (USACE). The AFEP study code is ADS-W-12-1: Steelhead kelt passage distributions and Federal Columbia River Power System survival and return rates for fish tagged above and at Lower Granite Dam. Pacific Northwest National Laboratory (PNNL) was the prime contractor for the USACE Walla Walla District. The USACE technical lead was Chris Pinney. The PNNL project manager was Alison Colotelo (509-371-7248). Study data are archived at PNNL offices in Richland, Washington.

Suggested citation:

Colotelo AH, RA Harnish, and BW Jones, and 10 other authors. 2014. Passage Distribution and Federal Columbia River Power System Survival for Steelhead Kelts Tagged Above and at Lower Granite Dam, Year 2. PNNL-23051, prepared for the U.S. Army Corp of Engineers, Walla Walla District, Walla Walla Washington, by Pacific Northwest National Laboratory, Richland, Washington. 


\begin{abstract}
Steelhead (Oncorhynchus mykiss) populations have declined throughout their range in the last century and many populations, including those of the Snake River Basin are listed under the Endangered Species Act of 1973. The reasons for their decline are many and complex, but include habitat loss and degradation, overharvesting, and dam construction. The 2008 Biological Opinion calls for an increase in the abundance of female steelhead through an increase in iteroparity (i.e., repeat spawning) and this can be realized through a combination of reconditioning and in-river survival of migrating kelts. The goal of this study is to provide the data necessary to inform fisheries managers and dam operators of Snake River kelt migration patterns, survival, and routes of dam passage. Steelhead kelts $(n=487)$ were captured and implanted with acoustic transmitters and passive integrated transponder (PIT)-tags at the Lower Granite Dam (LGR) Juvenile Fish Facility and at weirs located in tributaries of the Snake and Clearwater rivers upstream of LGR. Kelts were monitored as they moved downstream through the Federal Columbia River Power System (FCRPS) by 15 autonomous and 3 cabled acoustic receiver arrays. Cabled receiver arrays deployed on the dam faces allowed for three-dimensional tracking of fish as they approached the dam face and were used to determine the route of dam passage. Overall, 27.3\% of the kelts tagged in this study successfully migrated to Martin Bluff (rkm 126, as measured from the mouth of the Columbia River), which is located downstream of all FCRPS dams. Within individual river reaches, survival per kilometer estimates ranged from 0.958 to 0.999 ; the lowest estimates were observed in the immediate forebay of FCRPS dams. Steelhead kelts tagged in this study passed over the spillway routes (spillway weirs, traditional spill bays) in greater proportions and survived at higher rates compared to the few fish passed through powerhouse routes (turbines and juvenile bypass systems). The results of this study provide information about the route of passage and subsequent survival of steelhead kelts that migrated through the Snake and Columbia rivers from LGR to Bonneville Dam in 2013. These data may be used by fisheries managers and dam operators to identify potential ways to increase the survival of kelts during their seaward migrations.
\end{abstract}




\section{Executive Summary}

Steelhead (Oncorhynchus mykiss) populations throughout the Pacific Northwest have declined during the last century and many populations, including Snake River steelhead, are listed as threatened under the Endangered Species Act of 1973. The causes of population declines are many and complex but include habitat loss and degradation, overharvesting, and dam construction. The 2008 Biological Opinion calls for a 6\% increase in Snake River B-run female steelhead abundance through an increase in iteroparity rates. Improving survival of post-spawn downstream migrants (known as kelts) through Federal Columbia River Power System (FCRPS) dams may contribute to an increase in iteroparity rates and improve population abundance and productivity. The goal of the study reported herein is to provide the data necessary to inform fisheries managers and dam operators of Snake River steelhead kelt migration patterns, survival, and dam passage routes. The data may be used to adaptively manage the configuration and operation of FCRPS dams to maximize kelt survival.

\section{Objectives}

In this report, we present demographic summaries, survival estimates, and passage metrics of Snake River steelhead kelts tagged with acoustic transmitters at Lower Granite Dam (LGR) and several tributary sites within the Snake River basin upstream of LGR. The field study period was from 11 April through 26 August 2013. The objectives were as follows:

- Estimate the proportion of kelts that passed through each dam passage route and estimate routespecific survival probabilities at each FCRPS dam where acoustic transmitter detection capabilities existed.

- Estimate the following passage metrics and timing of kelts implanted with acoustic transmitters:

- forebay residence time: travel time between the entrance to the forebay of the dam and passage through the dam. In this study, the forebay included the river reach $1 \mathrm{~km}$ upstream of the dam.

- tailrace egress time: travel time between passage through the dam and exit from the tailrace of the dam. In this study, the tailrace included the river reach 1 to $2 \mathrm{~km}$ downstream of the dam.

- project passage time: travel time between the entrance to the forebay and exit from the tailrace of the dam. In this study, the project included the river reaches $1 \mathrm{~km}$ upstream of the dam and 1 to $2 \mathrm{~km}$ downstream of the dam.

- Estimate the annual population abundance of kelts that arrived at and passed LGR in 2013.

\section{Methods}

The study area spanned the lower Snake and Columbia rivers as well as selected tributary sites within the Snake River basin upstream of LGR. Steelhead kelts were captured and tagged at the LGR Juvenile Fish Facility (JFF; rkm 695 measured from the mouth of the Columbia River) and at weirs located on Asotin Creek (rkm 761), Joseph Creek (rkm 800), the Potlatch River (rkm 836), and Fish Creek (rkm 944).

The objectives of this study were accomplished using the Juvenile Salmon Acoustic Telemetry System (JSATS), which enables researchers to monitor the movement of fish that are tagged with acoustic 
transmitters using a series of acoustic receivers. For this study, JSATS transmitters were surgically implanted into the coelom of each kelt. After they recovered from surgery, kelts were released into the LGR tailrace or downstream of the tributary weir where they could continue their seaward migrations. In 2013, tagged kelts could have been detected on up to 3 cabled and 15 autonomous receiver arrays that were deployed in the Snake and Columbia rivers. Cabled receiver arrays were located on the dam faces of LGR, Little Goose Dam (LGS), and Lower Monumental Dam (LMN) in the lower Snake River and allowed for three-dimensional tracking of fish as they approached the dam face and for determining the dam passage route. Autonomous receiver arrays were located in the forebays, tailraces, and reservoirs of these dams, as well as at strategic locations in the lower Snake and Columbia rivers, including downstream of Bonneville Dam (BON; the most downstream FCRPS dam).

Survival estimates were calculated for each river reach between acoustic receiver arrays and for each main dam passage route (i.e., spillway weir, traditional spill, turbine, juvenile bypass system [JBS]) using detections on downstream arrays. In addition, elapsed times for forebay residence (forebay to dam-face array), tailrace egress (dam face to tailrace array), and project passage (forebay to tailrace array) were calculated for each kelt tagged with an acoustic transmitter detected on both the upstream and downstream arrays.

\section{Results}

\section{Survival Estimates and Passage Proportions}

Overall, $27.3 \%$ ( $n=133$ of 487 ) of kelts that were tagged in this study successfully migrated to Martin Bluff (rkm 126), which is located downstream of all FCRPS dams. Within individual river reaches, survival probability estimates ranged from $0.657(\mathrm{SE}=0.042)$ to $0.978(\mathrm{SE}=0.013)$. Because river reaches varied in length, the survival per kilometer was also calculated and found to be lowest in the immediate forebay of FCRPS dams. The LGS forebay reach (rkm 636 to 635) had the lowest survival per kilometer (0.9580). Survival per kilometer was generally highest in the upstream- and downstream-most reaches of the study area (tributaries to LGS forebay [rkm 636] and Burbank [rkm 525] to Martin Bluff [rkm 126]).

Tagged kelts passed through the spillway routes (spillway weirs or traditional spill bays) in greater proportions during this study, whereas few fish passed through the powerhouse routes (turbines or JBS). Survival estimates of fish that passed via the spillway weir at LGS (0.936; SE = 0.016) and LMN (0.927; $\mathrm{SE}=0.018$ ) were high compared to other routes. Route-specific survival estimates were also high for kelts that passed through the JBS at LMN (0.938; SE = 0.061); however, very few fish passed through this route $(n=16$, or and $5.4 \%)$.

\section{Passage Times and Travel Rates}

Forebay residence and tailrace egress times were consistent among LGR, LGS, and LMN in 2013. Median forebay residence times were less than 2.00 hours at all dams and median tailrace egress times were approximately 0.50 hours. Median project passage time in this study ranged from 2.00 (LMN) to 3.06 (LGR) hours. Overall, passage times were lowest for fish that passed LMN.

Of the kelts captured and tagged in the tributaries, those released in Fish Creek, which migrated the greatest distance through fluvial habitats, travelled fastest to Red Wolf Bridge (rkm 743; median = 88.2 
$\mathrm{km} /$ day). Once kelts reached rkm 743, travel rates through river reaches tended to increase as tagged kelts moved downstream. Median travel rates were noticeably lower when kelts moved through the dam forebays (12.5 to $17.8 \mathrm{~km} /$ day), than through fluvial habitats such as dam tailraces (46.2 to 130.0 $\mathrm{km} /$ day). Overall travel time from the LGR tailrace ( $\mathrm{rkm} \mathrm{693)}$ ) to rkm 126 ranged from 7.3 to 23.5 days for the 133 tagged kelts that successfully migrated all the way through the FCRPS in 2013. These travel times represent travel rates that ranged from 24.2 to $77.7 \mathrm{~km} /$ day.

\section{Annual Kelt Abundance at LGR}

Two independent estimates of LGR kelt abundance were derived from the available data. Dividing the number of kelts sampled on the LGR JFF separator by the probability of tagged kelts passing LGR via the JBS produced a population estimate of 19,630 kelts that passed LGR. Calculating the population abundance separately for marked and unmarked kelts produced an estimated 7,819 marked and 11,811 unmarked kelts that passed LGR in 2013. Using the Lincoln-Petersen mark-recapture method on kelts marked at the tributary weirs and recaptured at the LGR JFF separator, an estimated 14,022 kelts were present at the time of tagging. Multiplying this estimate by the pooled survival probability from the tributary weirs to LGR, we obtained an estimate of 11,750 unmarked kelts that arrived at LGR. Agreement of these two independent estimates of the number of unmarked kelts leads us to believe they are relatively accurate and precise. These estimates indicate that $18 \%(n=19,630)$ of the 110,675 adult steelhead estimated to have passed LGR on their way to spawning grounds and hatcheries located upstream of LGR in 2012, survived the spawning event, and migrated back downstream to LGR as kelts in 2013.

\section{Conclusions}

The results of this study provide information about the route of passage and subsequent survival of steelhead kelts that migrated through the Snake and Columbia rivers from LGR to BON in 2013. Specifically, this study builds on information collected in 2012, which was the first to document these metrics since the installation of spillway weirs at many of the dams in the FCRPS. Similar to 2012, spillway weirs were the primary route of passage for steelhead kelts in the Snake River in 2013. Spillway weirs provided the highest estimated survival at LGS and LMN, which is also consistent with the results from the 2012 study. Overall, very few fish passed through the turbine and JBS routes at any of the dams. Therefore, estimates of turbine and JBS survival should be interpreted with caution. Mean river discharge was lower in 2013 compared to 2012 and likely contributed to differences in migration success, survival estimates, and travel rates between years.

Although the results of this study contribute to understanding the effect of dam configuration and operations on steelhead kelt migration in the FCRPS, future research is warranted. Future studies should focus on sampling throughout the full kelt emigration period, specifically prior to the opening of the spill bays, and on tagging a larger proportion of kelts in fair and poor condition. Such studies should also collect kelts from additional locations in the Snake River basin to acquire information that is applicable to a larger proportion of the Snake River steelhead population. 


\section{Acknowledgments}

Many people made valuable contributions to this study and deserve acknowledgment. Scott Everett (Nez Perce Tribe), Neil Graham (Columbia River Inter-Tribe Fish Commission), Mike Halter (U.S. Army Corps of Engineers, Walla Walla District), Brett Bowersox (Idaho Department of Fish and Game), Paul Kucera (Nez Perce Tribe), Ethan Crawford (Washington Department of Fish and Wildlife), Tim Copeland (Idaho Department of Fish and Game), Matt Corsi (Idaho Department of Fish and Game), and Jocelyn Hatch (Nez Perce Tribe) were very helpful in coordinating daily fish sampling at Lower Granite Dam (LGR) and tributary weirs. Seasonal staff of the respected agencies also assisted with fish sampling and tagging. Brenda James of Cascade Aquatics assisted with fish tagging. Rich Hilt, Ryan Bliss, and Rob Lustig (U.S. Army Corps of Engineers, Walla Walla District) were helpful in coordinating the

deployment and demobilization of cabled receivers at LGR. Darin Etherington, Tyler Mitchell, and Scott Carpenter (Pacific States Marine Fisheries Commission) contributed by maintaining arrays of autonomous acoustic receivers deployed in the lower Columbia River. Adam Seaburg (Columbia Basin Research) provided statistical support for the mark-recapture population estimate.

Advanced Telemetry Systems, Inc. manufactured the Juvenile Salmon Acoustic Telemetry System acoustic transmitters as well as the autonomous and cabled receivers.

Many Pacific Northwest National Laboratory (PNNL) staff assisted in many aspects of this study, including deployment and maintenance of acoustic receivers (Scott Titzler, John Stephenson, Bob Mueller, Kyle Larson, Brian Jeide, Ryan Klett, Eric Oldenburg, Evan Arntzen, James Hughes, Caleb Price, Eric Fischer, Brett Pflugrath, Jason Reynolds, and Brian Bellgraph), acoustic telemetry data processing (Jayson Martinez, John Ingraham, Huiying Ren, Yong Yuan, Tylor Abel, and Craig Swartout), and scientific permitting (Kris Hand). Susan Ennor, Kathy Neiderhiser, and Heather Culley provided editing and document production support for this report. Gayle Dirkes provided administrative support for this project. Dr. David Geist was the Ecology Group Manager at PNNL, and Michelle Johnson and Steve Schlahta were the Project Management Office Directors during this study. 


\section{Acronyms and Abbreviations}

\begin{tabular}{|c|c|}
\hline $3 \mathrm{D}$ & three-dimensional \\
\hline AFEP & Anadromous Fish Evaluation Program \\
\hline B2CC & Bonneville Dam second powerhouse corner collector \\
\hline $\mathrm{BiOp}$ & Biological Opinion \\
\hline BON & Bonneville Dam \\
\hline${ }^{\circ} \mathrm{C}$ & degree(s) Celsius or centigrade \\
\hline cfs & cubic feet per second \\
\hline $\mathrm{cm}$ & centimeter(s) \\
\hline CR & Columbia River \\
\hline CRB & Columbia River Basin \\
\hline DART & Data Access in Real Time \\
\hline ESA & Endangered Species Act of 1973 \\
\hline FCRPS & Federal Columbia River Power System \\
\hline $\mathrm{ft}$ & foot(feet) \\
\hline GPS & Global Positioning System \\
\hline IHR & Ice Harbor Dam \\
\hline JBS & juvenile bypass system \\
\hline JDA & John Day Dam \\
\hline JFF & juvenile fish facility \\
\hline JSATS & Juvenile Salmon Acoustic Telemetry System \\
\hline kcfs & thousand cubic feet per second \\
\hline $\mathrm{kg}$ & kilogram(s) \\
\hline $\mathrm{km}$ & kilometer(s) \\
\hline $\mathrm{L}$ & liter(s) \\
\hline LGR & Lower Granite Dam \\
\hline LGS & Little Goose Dam \\
\hline LMN & Lower Monumental Dam \\
\hline $\mathrm{m}$ & meter(s) \\
\hline $\mathrm{mm}$ & millimeters(s) \\
\hline MCN & McNary Dam \\
\hline mg & milligram(s) \\
\hline $\min$ & minute(s) \\
\hline MS-222 & tricaine methanesulfonate \\
\hline$N$ & population \\
\hline$n$ & sample \\
\hline NGVD29 & National Geodetic Vertical Datum of 1929 \\
\hline
\end{tabular}


NMFS

NPT

NOAA

PIT

PNNL

PTAGIS

RPA

rkm

SE

TDA

USACE
National Marine Fisheries Service

Nez Perce Tribe

National Oceanic and Atmospheric Administration

passive integrated transponder

Pacific Northwest National Laboratory

PIT Tag Information System

reasonable and prudent alternative

river kilometer(s)

standard error

The Dalles Dam

U.S. Army Corps of Engineers 


\section{Contents}

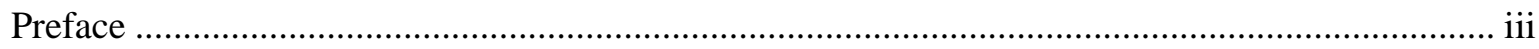

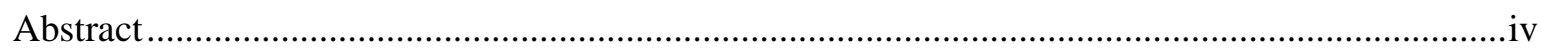

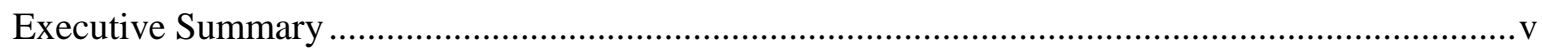

Acknowledgments.................................................................................................................. vii

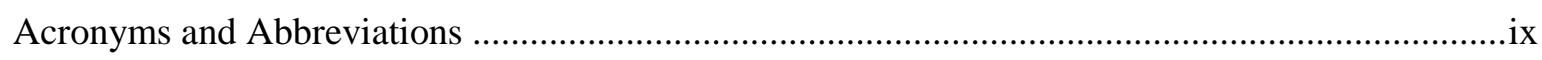

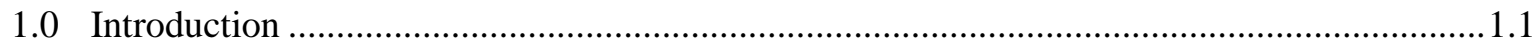

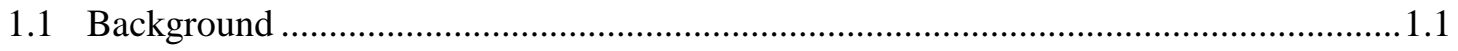

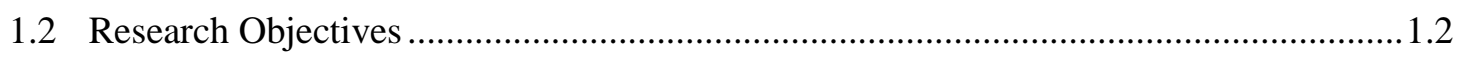

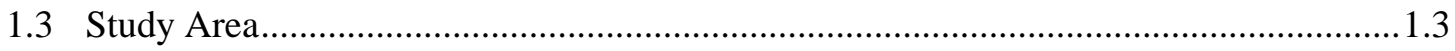

1.3.1 FCRPS Dams.......................................................................................... 1.3

1.3.2 Steelhead Kelt Capture Sites ..................................................................... 1.7

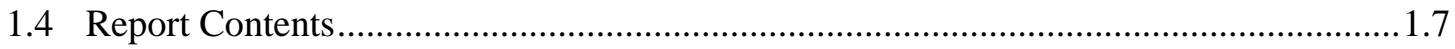

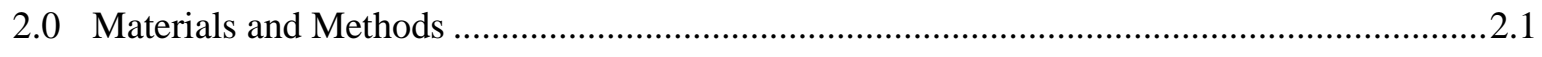

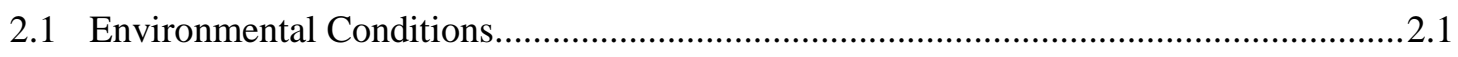

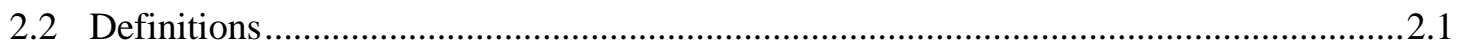

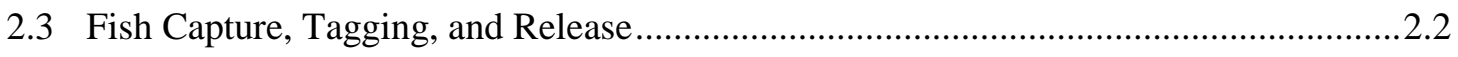

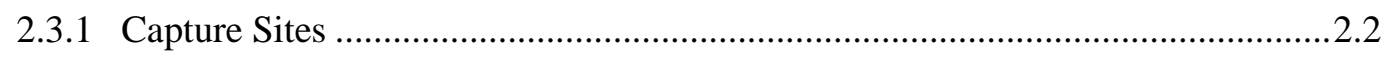

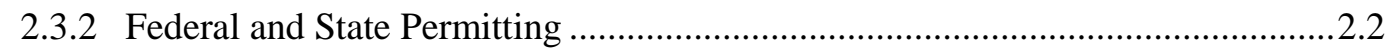

2.3.3 Sampling Methods........................................................................................... 2.3

2.3.4 Implantation of Passive Integrated Transponder Tags and Acoustic

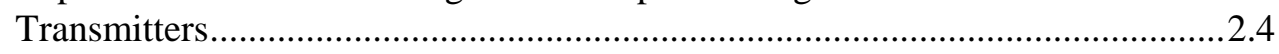

2.3.5 Recovery, Holding, and Release .................................................................... 2.5

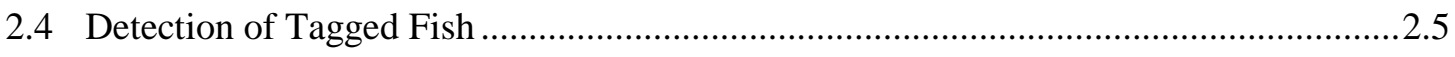

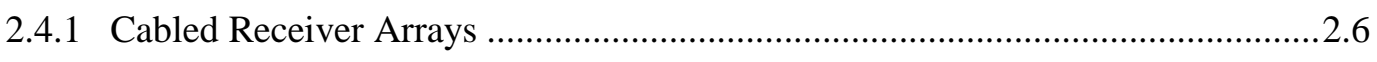

2.4.2 Autonomous Receiver Arrays ......................................................................... 2.7

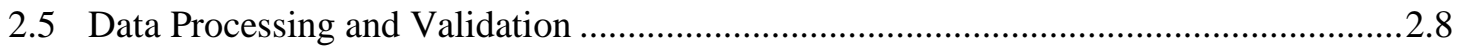

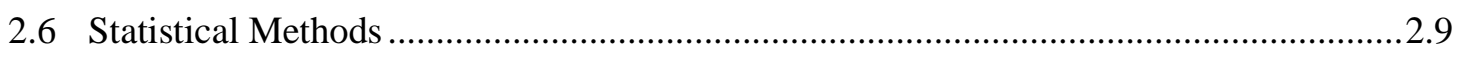

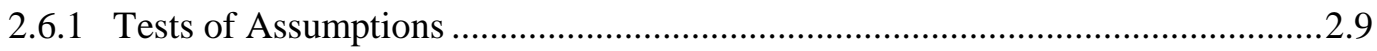

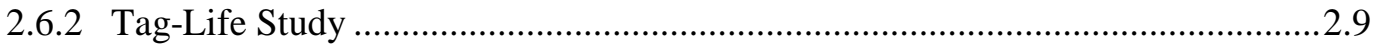

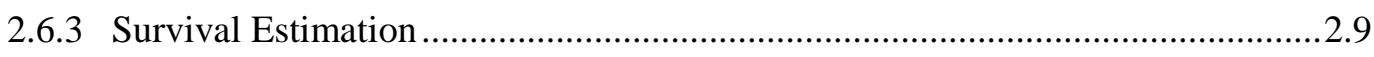

2.6.4 Determination of Passage Proportion................................................................2.11

2.6.5 Estimation of Passage Times and Travel Rates.................................................2.11

2.6.6 Estimation of Population Abundance Arriving at Lower Granite Dam ..............2.11

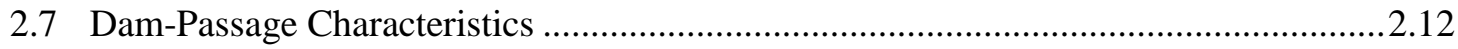

2.7.1 Dam Passage versus Flow ….......................................................................2.12

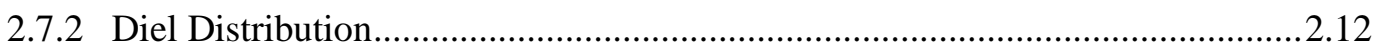

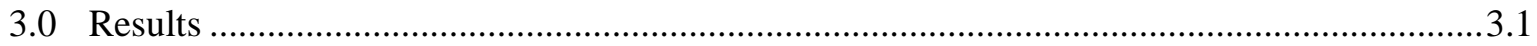




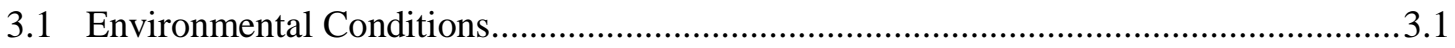

3.2 Kelt Migration Timing and Demographics ................................................................... 3.1

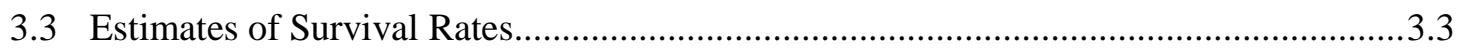

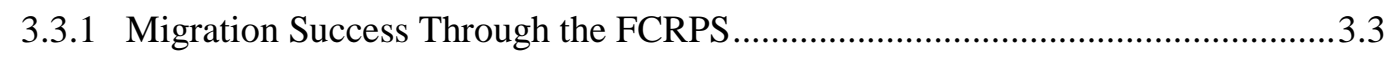

3.3.2 Survival Estimates Through the FCRPS ............................................................. 3.5

3.3.3 Passage Proportions and Survival Estimates Through Each FCRPS Dam ...........3.8

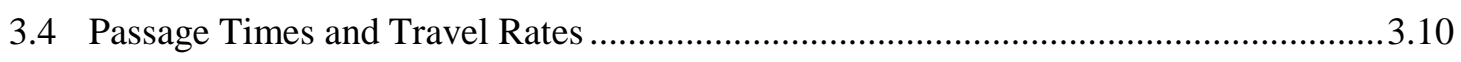

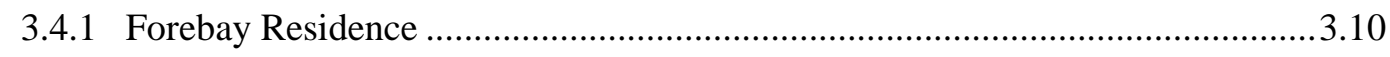

3.4.2 Tailrace Egress …........................................................................................ 3.12

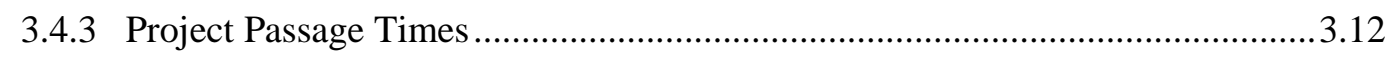

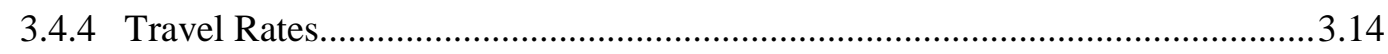

3.5 Estimation of Population Abundance Arriving at Lower Granite Dam .........................3.15

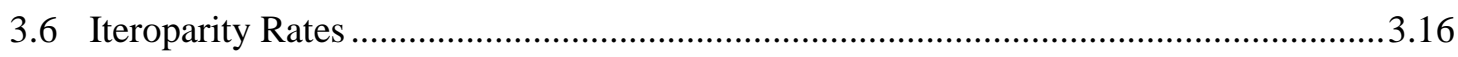

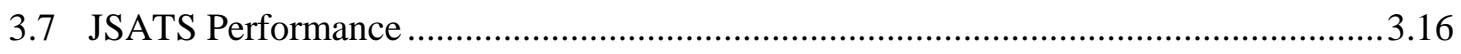

3.7.1 Detection Probabilities at Cabled and Autonomous Arrays .................................3.16

3.7.2 Multiple Detections on Autonomous Arrays........................................................16

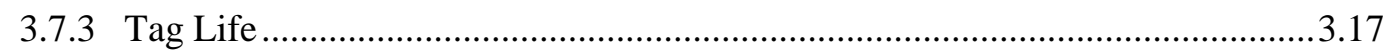

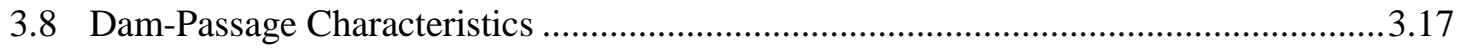

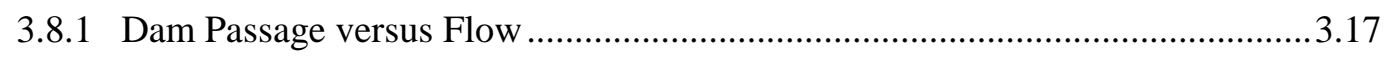

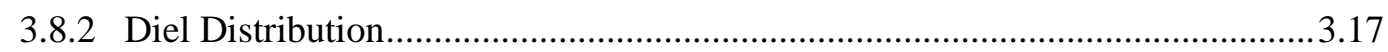

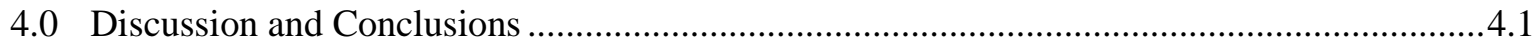

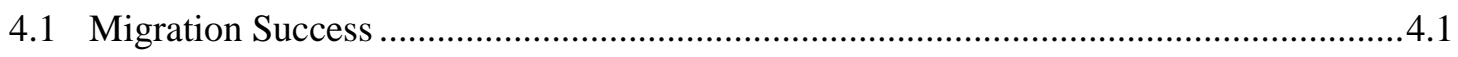

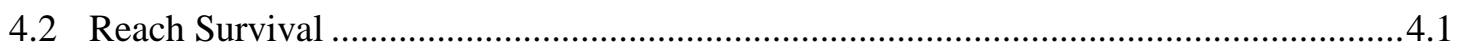

4.3 Passage Proportions and Route-Specific Survival .......................................................... 4.6

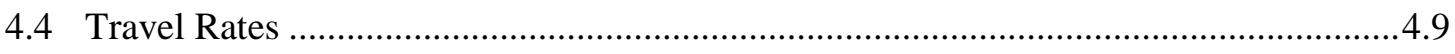

4.5 Population Abundance .............................................................................................

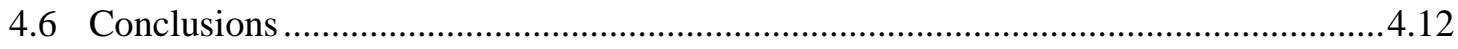

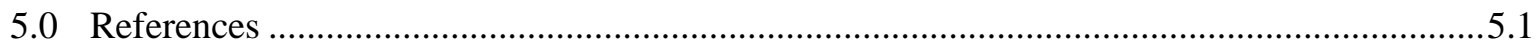

Appendix A - Hydrophone and Autonomous Node Deployment Tables and Locations of Fish

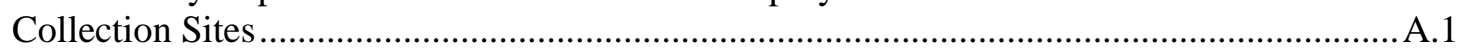

Appendix B - Steelhead Kelt Data Collected at Tagging.......................................................... B.1

Appendix C - Timing of Juvenile Salmon Acoustic Telemetry System-Tagged Kelts Passage

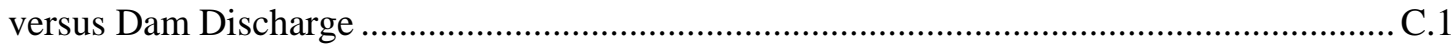

Appendix D - Discharge versus Spill at Each Dam .............................................................. D.1

Appendix E - Timing of Kelt Passage versus Temperature ....................................................... E.1

Appendix F - Timing of Kelts Captured and Tagged at Tagging Sites ............................................1

Appendix G - Juvenile Salmon Acoustic Telemetry System Performance......................................1

Appendix H - Juvenile Salmon Acoustic Telemetry System-Tagged Kelts Dam Passage versus

Flow 


\section{Figures}

1.1. Locations of acoustic telemetry receiver arrays used to detect acoustic-tagged steelhead kelts that migrated through the Federal Columbia River Power System in 2013.

1.2. Sites where steelhead kelts were captured and tagged with acoustic transmitters in 2013 including Lower Granite Dam, Asotin Creek, Potlatch River, Joseph Creek, and Fish Creek.

1.3. Aerial photograph of Lower Granite Dam............................................................................. 1.5

1.4. Aerial photograph of Little Goose Dam............................................................................... 1.6

1.5. Aerial photograph of Lower Monumental Dam. The spillway weir is located on the north side of the spillway.

2.1. Photograph of a steelhead kelt that was in good condition at the time of tagging ..................... 2.4

2.2. Photograph of a steelhead kelt that was in fair condition at the time of tagging

2.3. Photograph of the incision area of a female steelhead kelt implanted with an acoustic transmitter.

2.4. The autonomous acoustic receiver system used in 2013, including the hydrophone, acoustic receiver, acoustic release, and anchor.

3.1. Standardized reach survival probability estimates for all tagged steelhead kelts detected in the Federal Columbia River Power System in 2013.

3.2. Cumulative survival probabilities of steelhead kelts from the Little Goose Dam forebay array to rkm 126 by tagging location

3.3. Frequency distribution of forebay residence times for steelhead kelts that passed Lower Granite, Little Goose, and Lower Monumental dams in 2013.

3.4. Frequency distribution of tailrace egress times for steelhead kelts that passed Lower Granite, Little Goose, and Lower Monumental dams in 2013.

3.5. Frequency distribution of project passage times for steelhead kelts that passed Lower Granite, Little Goose, and Lower Monumental dams in 2013.

3.6. Median travel rates of steelhead kelts through various reaches of the Snake and Columbia rivers from rkm 743 to 113 in 2013.

4.1. Total daily discharge from McNary Dam in years that steelhead kelt telemetry studies occurred in the Federal Columbia River Power System.

4.2. Total daily discharge from Lower Granite Dam in years that steelhead kelt telemetry studies occurred in the Federal Columbia River Power System.

4.3. Daily temperatures recorded at McNary Dam in years that steelhead kelt telemetry studies occurred in the Federal Columbia River Power System.

4.4. Standardized reach survival probability estimates for all tagged steelhead kelts detected in the Federal Columbia River Power System in 2012 and 2013. 
4.5. (A) Cumulative survival estimates from release to the forebay of Little Goose Dam for good and fair condition kelts tagged in the tributaries of the Snake and Clearwater rivers in 2013. (B) Cumulative survival estimates from the forebay of Little Goose Dam to the forebay of Bonneville Dam for good and fair condition kelts tagged in the tributaries and at the Lower Granite Dam Juvenile Fish Facility in 2013

4.6. Tailrace egress time of steelhead kelts that passed Lower Granite, Little Goose, and Lower Monumental dams over time in 2013.

\section{Tables}

1.1. Distances between locations referenced in this study.

2.1. Total river kilometers from each acoustic receiver array to the mouth of the Columbia River, along with the description, location, name, and function of each array deployed in 2013.

2.2. Assumptions of the virtual single-release model and tests of the assumptions.

3.1. Mean, maximum, and minimum discharge values and percentage spill at Lower Granite, Little Goose, and Lower Monumental dams for the time period between the tagging of the first kelt and the last detection of a kelt at any acoustic array in the Snake River.

3.2. Dates of first and last kelt captured and tagged at Lower Granite Dam, Asotin Creek, Potlatch River, Joseph Creek, and Fish Creek, and the dates when 10\%, 25\%, 50\%, 75\%, and $90 \%$ of the kelt at each location had been tagged.

3.3. Dates that the first and last kelts implanted with an acoustic transmitters passed Lower Granite, Little Goose, and Lower Monumental dams and dates when 10\%, 25\%, 50\%, $75 \%$, and $90 \%$ of the kelt had passed each dam.

3.4. Sex ratios and total number of kelts tagged at Lower Granite Dam, Asotin Creek, Potlatch River, Joseph Creek, and Fish Creek along with total number tagged, median fork length, and weight of males and females tagged at each site.

3.5. Reach survival estimate for all steelhead kelts implanted with acoustic transmitters that were detected in 2013 throughout the Federal Columbia River Power System

3.6. Passage percentages and route-specific survival estimates of tagged kelts that passed through Lower Granite, Little Goose, and Lower Monumental dams during the 2013 season

3.7. Distance of travel and median forebay residence time for steelhead kelts implanted with acoustic transmitters at Lower Granite, Little Goose, and Lower Monumental dams in 2013.

3.8. Number of kelts last detected on the forebay array after detection on the dam-face cabled array at Lower Granite, Little Goose, and Lower Monumental dams.

3.9. Distance of travel and median tailrace egress time for steelhead kelts implanted with acoustic transmitters at Lower Granite, Little Goose, and Lower Monumental dams in 2013.

3.10. Distance of travel and median project passage time for steelhead kelts implanted with acoustic transmitters at Lower Granite, Little Goose, and Lower Monumental dams in 2013.. 
4.1. Summary of studies examining the downstream migration success of steelhead kelts in the Federal Columbia River Power System .

4.2. The percentage and route-specific survival estimates of tagged kelts that passed through Lower Granite, Little Goose, and Lower Monumental dams during the 2012 and 2013 seasons

4.3. The percentage and route-specific survival estimates of fair and good condition kelts that passed through Lower Granite Dam during the 2013 season. 


\subsection{Introduction}

This report documents the results from the second year of a steelhead kelt migration and FCRPS dam passage study conducted by Pacific Northwest National Laboratory (PNNL) for the U.S. Army Corps of Engineers (USACE), Walla Walla District, during spring and summer 2013. The goal of this study was to quantify migration patterns and estimate dam passage metrics of Snake River steelhead kelts passing through hydroelectric facilities in the FCRPS. These data may be used to understand sources of mortality and inform managers and dam operators of potential ways to increase the survival of kelts during their seaward migrations. The data presented here will allow for comparisons of kelt migration and survival with respect to annual differences in environmental conditions and a larger range of fish physical condition.

\subsection{Background}

Adult summer steelhead (Oncorhynchus mykiss) enter freshwater during the summer months and, once mature, spawn in the Snake River basin the next spring (March to May). Post-spawn kelts migrate downstream in an attempt to return to the ocean to restore their energy reserves (Busby et al. 1996). Steelhead sometimes exhibit iteroparity (i.e., repeat spawning), thus population fitness and reproductive success are highly dependent on survival between spawning events. Estimated annual iteroparity rates for Snake River steelhead range from 0.5 to $1.2 \%$, a lower rate compared to the 2.9 to $9.0 \%$ repeat spawners documented in the lower Columbia River (Keefer et al. 2008). Over the past few decades, steelhead populations in the Columbia River basin (CRB) have been greatly diminished and several stocks are listed for protection under the Endangered Species Act of 1973 (ESA; McClure et al. 2003; NMFS 2004). Causes for population declines are numerous and include overharvesting, loss and degradation of habitat, failed hatchery supplementation practices, predation, and various effects of dam passage (Lichatowich 2001; Budy et al. 2002; McClure et al. 2003; Brannon et al. 2004). However, the effect of these factors on steelhead iteroparity rates is not well understood. Reasonable and Prudent Alternative (RPA) 33 of the 2008 Biological Opinion (BiOp; NOAA 2008) identifies actions and requires measures to increase the survival of migrating kelts, with particular emphasis on B-run fish. B-run steelhead are primarily identified based on the timing of their upstream migration past Bonneville Dam (BON; late-August to October; Busby et al. 1996). Understanding sources of mortality and increasing the survival of kelts is an important step in improving iteroparity rates and potentially contributing to population recovery.

Repeat breeding can be advantageous and with higher adult survival the iteroparous life history strategy may be selected for genetically (Fleming and Reynolds 2004). Iteroparous species may have higher population abundance and productivity than semelparous (reproduce only once before dying) species because they are afforded multiple spawning opportunities in their lifetimes and, as a result, have increased lifetime fitness (Fleming and Reynolds 2004). Furthermore, Seamons and Quinn (2010) showed that steelhead repeat spawners produced more offspring during their second spawning run alone than did one-time spawners. Also, repeated breeding events allow for multiple breeding pairs across years, which may introduce greater genetic variability into a population. Variation in age-at-maturation and overlapping generations could reduce the risk of catastrophic population declines during years of low recruitment (Narum et al. 2008).

The energetic costs associated with migrations and spawning are high and past research suggests the probability of repeat spawning is reduced with greater migration distances (Keefer et al. 2008). During 
these large-scale migrations, post-spawn adult steelhead from the Snake River basin upstream of Lower Granite Dam (LGR) must also migrate downstream through eight Federal Columbia River Power System (FCRPS) dams in the lower Snake and Columbia rivers to reach the ocean. The effects of dam passage on iteroparity rates are currently not well understood. River impoundment may indirectly affect kelt migration by altering the environmental conditions (i.e., reducing flows, increasing water temperature), thereby causing delays in migration and additional physiological impairment when fish are already in an atrophied state. In turn, direct effects, such as mortality, may be a result of dam passage or an accumulation of factors such as long migration distances under unfavorable environmental conditions for kelts during their seaward-migration (Wertheimer and Evans 2005; Wertheimer 2007). There is a clear need for continued research to examine the effects of hydropower dam design and operation on iteroparous species (Kraabol et al. 2009).

Several studies have been conducted to evaluate the passage and survival of steelhead kelts as they migrated downstream through the FCRPS (Hatch et al. 2003; Boggs and Peery 2004; Wertheimer and Evans 2005). These studies were conducted nearly a decade ago, and since then several changes to the structure and operations of FCRPS dams have occurred, including installation of spillway weirs at most dams within the system, installation of the BON second powerhouse corner collector (B2CC), and implementation of a court-ordered spill program. These modifications, generally implemented to benefit salmonid smolt survival, may also have a significant positive effect on the survival and migration success of kelts, which tend to be surface oriented and have been shown to readily pass dams via surface passage routes (i.e., spillway weirs; Colotelo et al. 2013). Understanding how kelts respond to the recent changes at the dams will allow fish managers to focus efforts on providing feasible passage routes for outmigrating adults.

In addition to structural and operational modifications at FCRPS dams, annual variation in environmental conditions may also affect steelhead kelt migration through the FCRPS. In 2012, 37.0\% of the kelts survived seaward migrations through the FCRPS (Colotelo et al. 2013); this was a higher percentage than in previous studies where only $4.2 \%$ and $15.6 \%$ of kelts survived this migration in 2001 and 2002, respectively (Wertheimer and Evans 2005). Flow conditions in 2001 and 2002 were lower than average (47\% and 85\% of the 10-year average at LGR [1990-2000], respectively), while flows were above average in 2012 (109\% of 10-year average at LGR [2002-2011]), which highlights the need for additional behavioral studies that capture greater variation in annual flow regimes and may be useful for understanding kelt migration success. The physical condition of kelts may also affect migration success. Previous studies have shown that fish in good condition are more likely to successfully migrate to the ocean and return to spawn again (Boggs and Peery 2004; Keefer et al. 2008). Therefore, interpretation of results from various studies should account for the condition of kelts.

\subsection{Research Objectives}

In this report, we present demographic summaries, survival estimates, and passage metrics of Snake River steelhead kelts tagged with acoustic transmitters at LGR and several tributary sites within the Snake River basin upstream of LGR. The field study period was from 11 April through 26 August 2013. The objectives were as follows:

- Estimate the proportion of kelts that passed through each dam passage route and estimate routespecific survival probabilities at each FCRPS dam where acoustic transmitter detection capabilities existed. 
- Estimate the following passage metrics and timing of kelts implanted with acoustic transmitters:

- forebay residence time: travel time between the entrance to the forebay of the dam and passage through the dam. In this study, the forebay included the river reach $1 \mathrm{~km}$ upstream of the dam.

- tailrace egress time: travel time between passage through the dam and exit from the tailrace of the dam. In this study, the tailrace included the river reach 1 to $2 \mathrm{~km}$ downstream of the dam.

- project passage time: travel time between the entrance to the forebay and exit from the tailrace of the dam. In this study, the project included the river reaches $1 \mathrm{~km}$ upstream of the dam and 1 to $2 \mathrm{~km}$ downstream of the dam.

- Estimate the annual population abundance of kelts that arrived at, and passed, LGR.

\subsection{Study Area}

The CRB spans the majority of Washington, Oregon, Idaho, and southeastern British Columbia, and includes additional smaller portions in four neighboring states. Historically, the CRB was home to one of the largest runs of salmon and steelhead in the world (Chapman 1986; McClure et al. 2003). However, extensive hydroelectric development, habitat loss and degradation, overharvesting, and various other anthropogenic effects have caused many populations to decline (Nehlsen et al. 1991). Currently, 13 populations of salmon and steelhead within the CRB are listed under the ESA, including the Snake River steelhead evolutionarily significant unit, which is listed as Threatened (Busby et al. 1996). Hells Canyon and Dworshak dams completely block migration of Snake River steelhead to the upper Snake and North Fork Clearwater rivers, respectively. In addition, Snake River steelhead must pass up to eight FCRPS dams in the lower Snake and Columbia rivers during their migration.

This research study focused on the lower Snake and Columbia rivers from river kilometer (rkm) 944 (the location of the weir on Fish Creek as measured from the mouth of the Columbia River) to rkm 113 (near Kalama, Washington; Figure 1.1). Steelhead kelts were collected and tagged at four weir sites upstream of the detection area in tributaries of the Snake and Clearwater rivers (Figure 1.2), and at the LGR Juvenile Fish Facility (JFF). The distance from the mouth of the Columbia River for each of the FCRPS dams within the study area and tagging sites, as well as their distances from each other, are listed in Table 1.1.

\subsubsection{FCRPS Dams}

LGR is the fourth dam upstream from the mouth of the Snake River, $695 \mathrm{rkm}$ from the Pacific Ocean (Figure 1.3). It is the most upstream dam in the FCRPS that provides upstream fish passage. LGR consists of one powerhouse with six turbine units on the south side of the dam. The spillway has eight bays in the middle of the dam, and the southernmost bay is fitted with a spillway weir. An earthen-filled section also forms a portion of the dam. LGR is equipped with a juvenile bypass system (JBS) to route the portion of downstream migrants guided by in-turbine screens through the dam. Many of these fish are routed to monitoring and collection facilities for study and transportation. 


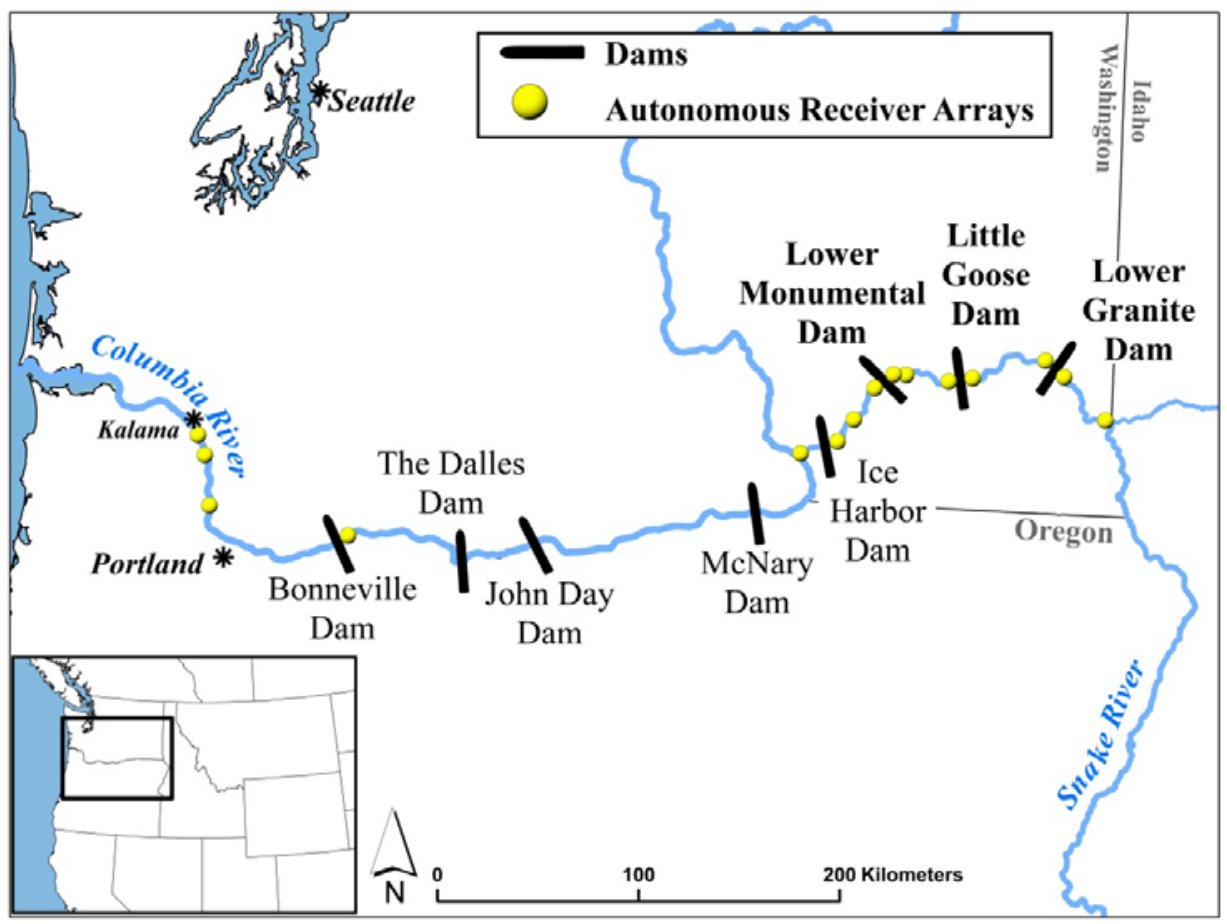

Figure 1.1. Locations of acoustic telemetry receiver arrays used to detect acoustic-tagged steelhead kelts that migrated through the Federal Columbia River Power System (FCRPS) in 2013. Cabled receiver arrays were located on the upstream dam-face of Lower Granite, Little Goose, and Lower Monumental dams (bolded text). Autonomous receiver arrays (yellow dots) were located in the forebay and tailrace of these dams and were used to estimate forebay residence, tailrace egress, and project passage times. In addition to cabled receiver arrays on the dams, autonomous receiver arrays were located at other locations in the Snake and lower Columbia rivers to detect fish for survival estimation.

Table 1.1. Distances (rkm) between locations referenced in this study.

\begin{tabular}{|c|c|c|c|c|c|c|c|c|c|}
\hline & Kilometers Upstream & LGR & LGS & LMN & IHR & $\mathrm{MCN}$ & JDA & TDA & $\mathrm{BON}$ \\
\hline Location & of CR Mouth & 695 & 635 & 589 & 538 & 470 & 349 & 309 & 234 \\
\hline Fish Creek & 944 & 249 & 309 & 355 & 406 & 474 & 595 & 635 & 710 \\
\hline Joseph Creek & 804 & 109 & 169 & 215 & 266 & 334 & 455 & 495 & 570 \\
\hline Potlatch River & 797 & 102 & 162 & 208 & 259 & 327 & 448 & 488 & 563 \\
\hline Asotin Creek & 761 & 66 & 126 & 172 & 223 & 291 & 412 & 452 & 527 \\
\hline LGR & 695 & 0 & 60 & 106 & 157 & 225 & 346 & 386 & 461 \\
\hline LGS & 635 & & 0 & 46 & 97 & 165 & 286 & 326 & 401 \\
\hline LMN & 589 & & & 0 & 51 & 119 & 240 & 280 & 355 \\
\hline IHR & 538 & & & & 0 & 68 & 189 & 229 & 304 \\
\hline MCN & 470 & & & & & 0 & 121 & 161 & 236 \\
\hline JDA & 349 & & & & & & 0 & 40 & 115 \\
\hline TDA & 309 & & & & & & & 0 & 75 \\
\hline BON & 234 & & & & & & & & 0 \\
\hline
\end{tabular}




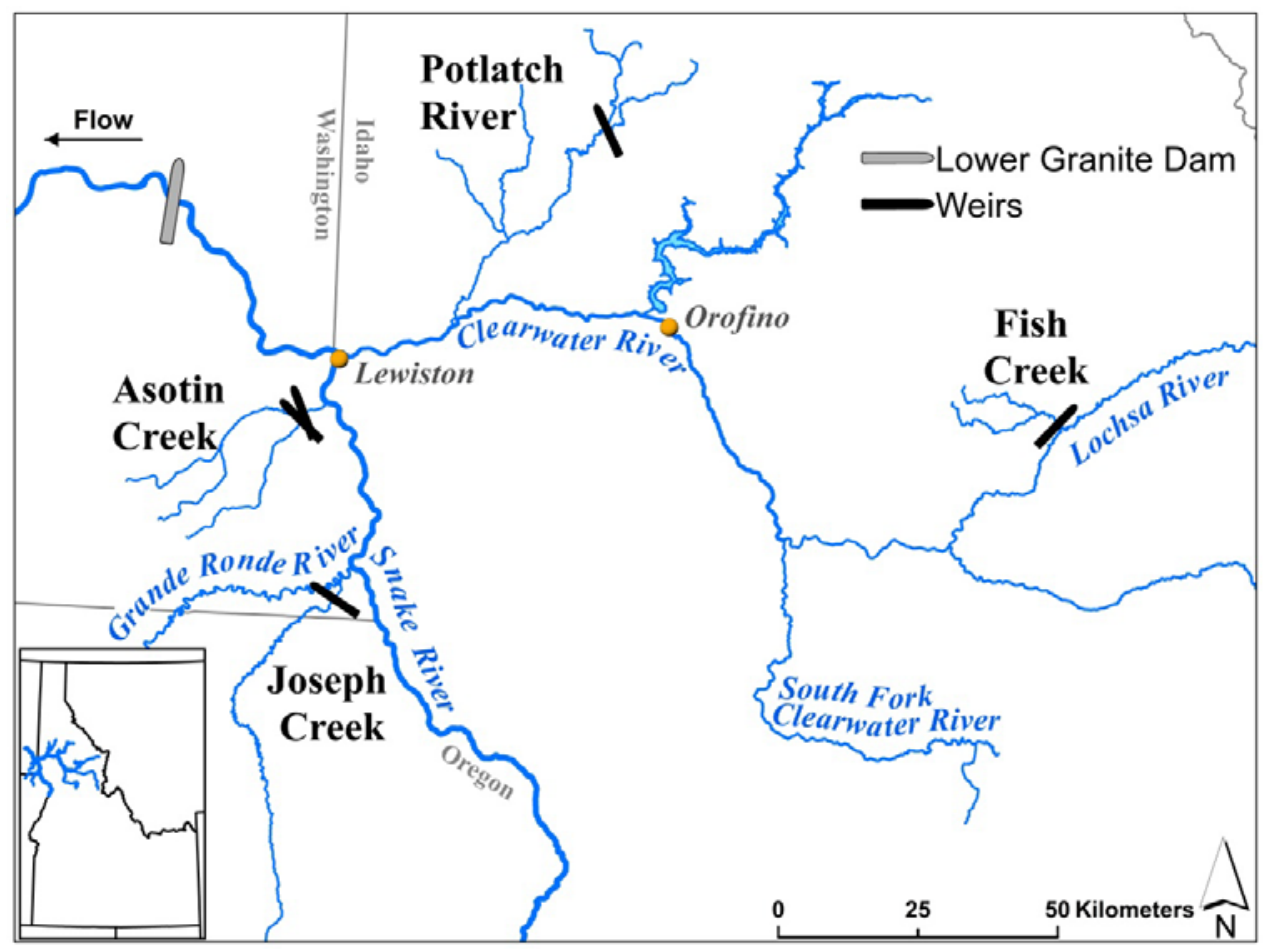

Figure 1.2. Sites where steelhead kelts were captured and tagged with acoustic transmitters in 2013 including Lower Granite Dam, Asotin Creek (and George Creek, an Asotin Creek tributary), Potlatch River, Joseph Creek, and Fish Creek.

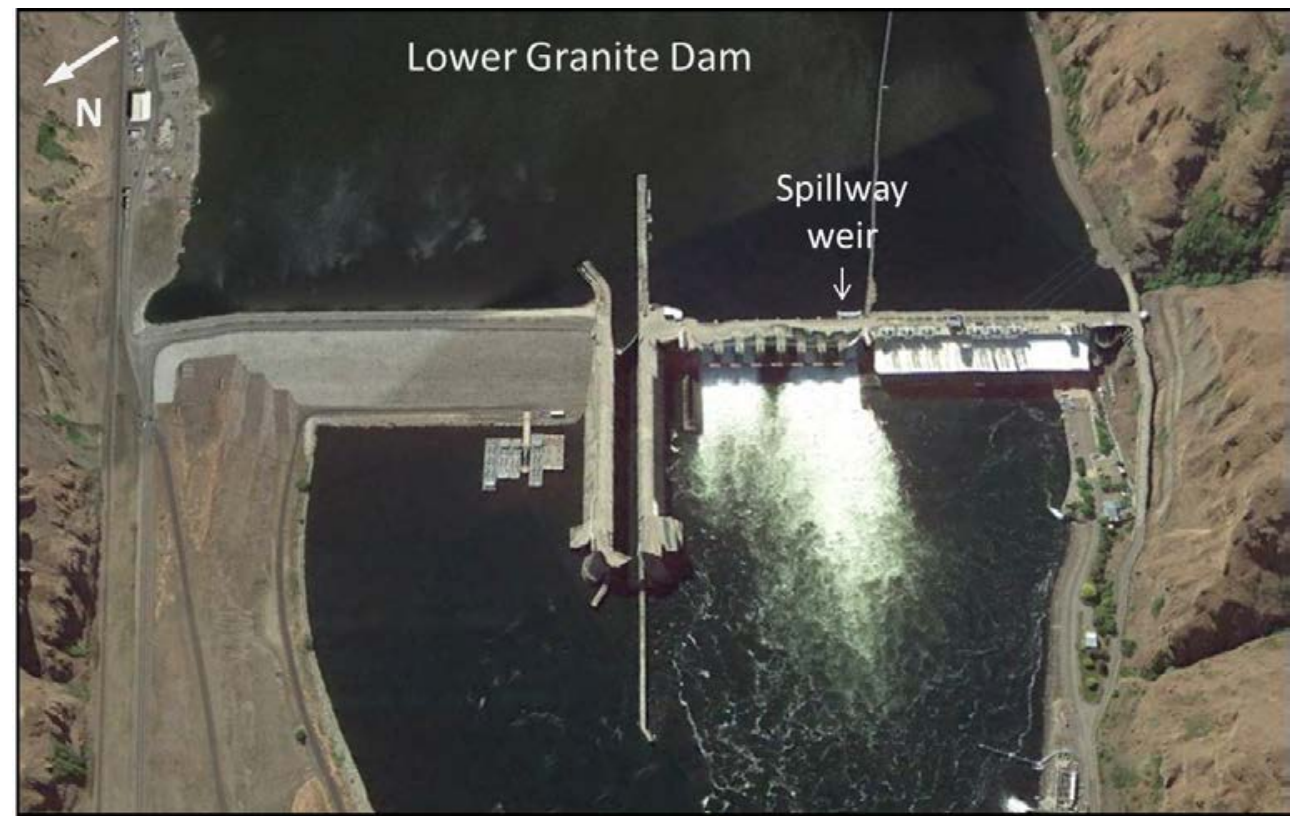

Figure 1.3. Aerial photograph of Lower Granite Dam. The spillway weir (surface route) is located on the south side of the spillway.

Little Goose Dam (LGS) spans the Snake River at rkm 635 (Figure 1.4). It has a single powerhouse with six turbine units on the south side of the dam. It also has eight spill bays in the middle of the river, 
one of which is equipped with a spillway weir to provide a surface passage route for downstream migrants, and an earthen-filled section on the north side. It is also equipped with a JBS.

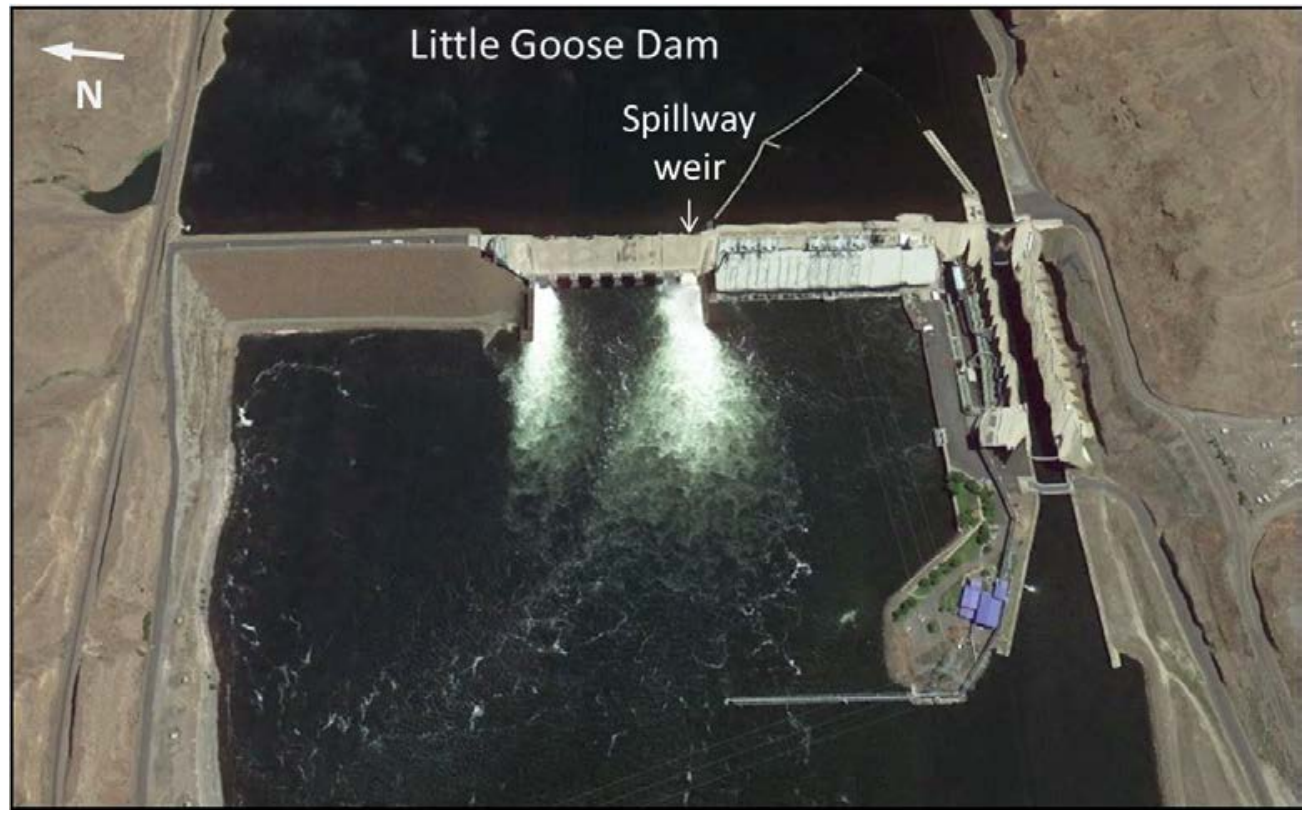

Figure 1.4. Aerial photograph of Little Goose Dam. The spillway weir (surface route) is located on the south side of the spillway.

Lower Monumental Dam (LMN) is on the Snake River at rkm 589 (Figure 1.5). It consists of six turbine units in a single powerhouse on the north side of the dam; eight spill bays, including one spillway weir on the south side; and a JBS.

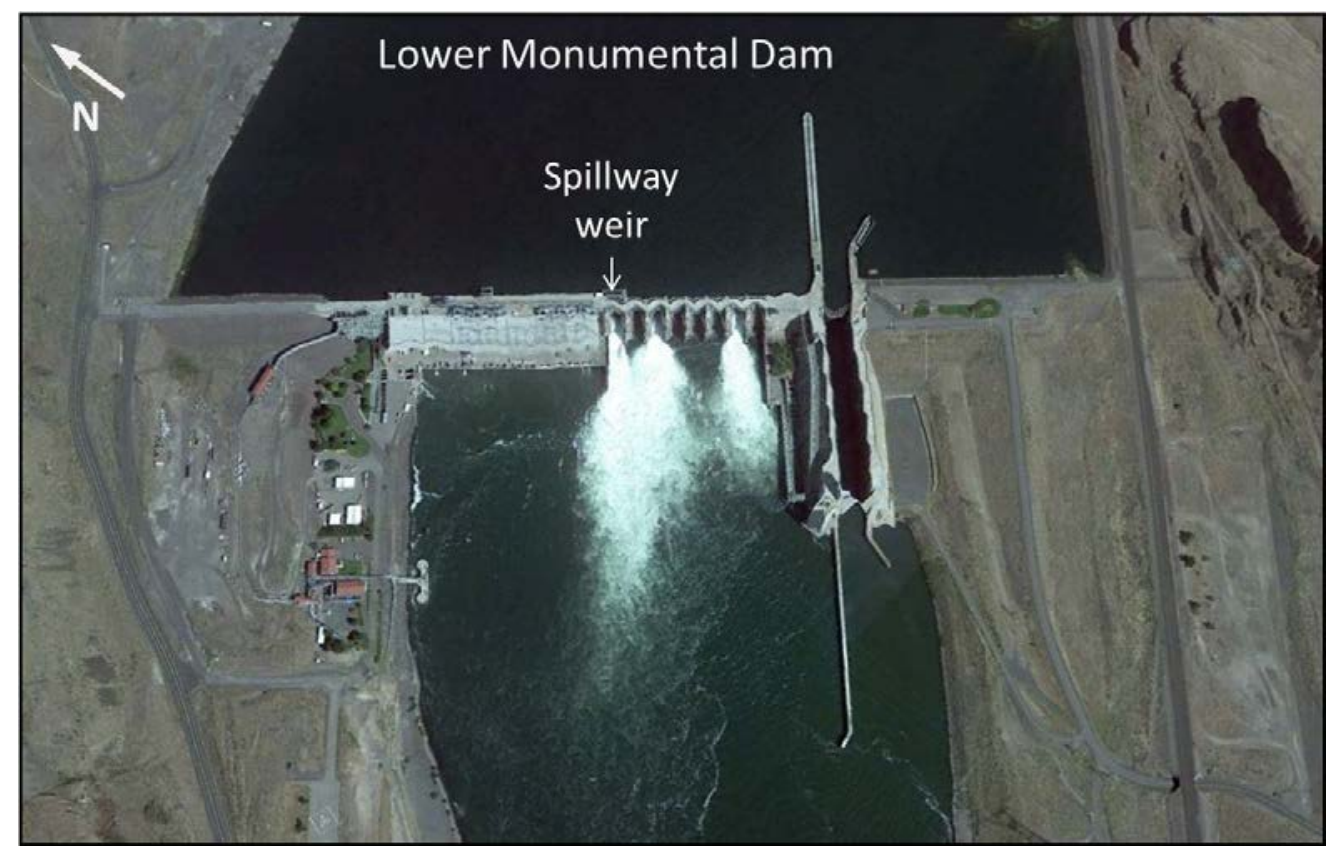

Figure 1.5. Aerial photograph of Lower Monumental Dam. The spillway weir (surface route) is located on the north side of the spillway. 
Unlike 2012, during the 2013 study the four lower Columbia River dams were not equipped with cabled receiver systems. As in 2012, Ice Harbor Dam (IHR) was not equipped with cabled receiver systems. For a description of these five dams, refer to the report by Colotelo et al. (2013).

\subsubsection{Steelhead Kelt Capture Sites}

Steelhead kelts were captured from the separator of the LGR JFF (rkm 695; Figure 1.2). Similar to the 2012 study, sampling at LGR was done in conjunction with an ongoing Nez Perce Tribe (NPT) study conducted to evaluate the feasibility of reconditioning Snake River steelhead kelts captured at LGR. Steelhead were also captured and tagged at four tributaries of the Snake and Clearwater rivers, including Asotin Creek (rkm 761), Joseph Creek (rkm 804), the East Fork of the Potlatch River (rkm 835), and Fish Creek (rkm 944). Kelts in the Asotin Creek drainage were captured at two weir sites: one on the main stem of Asotin Creek and the other on George Creek (rkm 762), a tributary of Asotin Creek. Colotelo et al. (2013) provided detailed descriptions of each capture site included in this study.

\subsection{Report Contents}

The ensuing sections of this report present the materials and methods (Section 2.0), results (Section 3.0), and discussion and conclusion (Section 4.0). Sources cited in the text may be found in Section 5.0. Ten appendices contain hydrophone and autonomous receiver deployment tables (Appendix A), data collected at the time of fish tagging (Appendix B), the timing of kelt passage versus dam discharge (Appendix C), discharge versus spill at each dam (Appendix D), the timing of kelt passage versus temperature (Appendix E), the run timing of untagged kelts captured at tagging sites (Appendix F), Juvenile Salmon Acoustic Telemetry System (JSATS) performance (Appendix G), plots of percentages of tagged kelts that passed through different routes at FCRPS dams relative to the percentage of flow (Appendix H), diel distributions of tagged kelts that passed through FCRPS dams (Appendix I), the routes of passage through multiple FCRPS dams (Appendix J) and the return rates of kelts tagged in this study (Appendix K). 


\subsection{Materials and Methods}

The source of data about environmental conditions; relevant definitions; fish capture, tag, release, and detection methods; data processing/validation and statistical methods; and dam-passage characteristics are described below.

\subsection{Environmental Conditions}

Data on total discharge, spill discharge, and forebay temperature in 2013, as well as the 10-year average (2003-2012) for each FCRPS dam, were downloaded from the Data Access in Real Time (DART) website (http://www.cbr.washington.edu/dart). Additional forebay temperature data collected by temperature strings in the forebay of each dam were downloaded from the USACE Technical Management Team (TMT) website (http://www.nwd-

wc.usace.army.mil/ftppub/water quality/tempstrings/). Daily discharge and temperature values represent the mean hourly values for each day.

\subsection{Definitions}

- Forebay is the segment of the reservoir immediately upstream of the dam where operations at the dam are the primary contributing factor to velocity and direction of water flow. The upstream boundary is the most upstream location where water velocity and direction of flow are altered by changes in dam operations (as defined for each dam by Rakowski et al. [2010]), and the downstream boundary is the upstream face of the dam. Autonomous receivers were deployed $1 \mathrm{~km}$ upstream of the dam face at the upstream boundary of the forebay at LGR, LGS, LMN, and IHR. The receiver array deployed at the upstream boundary of the BON forebay was located $2 \mathrm{~km}$ upstream of the dam face.

- Tailrace is the segment of the river immediately downstream of the dam where operations at the dam are the primary contributing factor to velocity and direction of flow. The upstream boundary of the tailrace is the downstream face of the dam, and the downstream boundary is where operational changes at the dam no longer affect the direction of water flow and mixing from the spillway and powerhouse is complete (as defined for each dam by Rakowski et al. [2010]). A tailrace exit array of autonomous receivers was deployed at the downstream boundary of the LGS tailrace and was located $1 \mathrm{~km}$ downstream of the dam face. Tailrace exit arrays of autonomous receivers were deployed at the downstream boundaries of the LGR and LMN tailraces and were located $2 \mathrm{~km}$ downstream of the dam face.

- The route-specific survival estimate is the probability of fish surviving when passing through any individual route (i.e., spillway weir, traditional spillway, turbine, JBS) to the second downstream array. In this study, the passage-route survival estimates were calculated for fish that passed through the turbines, JBS, spillway weirs, and traditional spillway, where traditional spill is passage through tainter or vertical lift gate openings and is any passage through the spillway that is not through the surface spillway weirs.

- Survival per kilometer is the probability of fish surviving passage through any individual reach of the river. It is calculated as $S^{1 / \mathrm{km}}$, where $S$ is the probability of survival in the reach and $\mathrm{km}$ is the 
length of the reach. This metric allows for comparison of survival through various river reaches that differ in length.

- Project passage timing is the time required to travel from the upstream boundary of the forebay to the downstream boundary of the tailrace. It is calculated as the difference in time between the first detection on the tailrace autonomous receiver array and the last detection on the forebay autonomous receiver array. The units used for reporting project passage timing are hours.

- Forebay residence is the time required to travel from the upstream boundary of the forebay to dam passage. It is calculated as the difference in time between the last detection on the cabled receiver array and the last detection (as the fish initially crosses the array) on the forebay autonomous receiver array. The units used for reporting forebay residence are hours.

- Tailrace egress is the time required to travel from the dam face to the downstream boundary of the tailrace. It is calculated as the difference in time between the last detection on the cabled receiver array and the first detection on the tailrace receiver array. The units used for reporting tailrace egress are hours.

- Reach travel rate is the rate of travel from the array at the upstream boundary of the reach of interest to the next downstream array. It is calculated as distance traveled divided by the difference in time between the last detection on the upstream receiver array and the first detection on the downstream receiver array. Reach travel rate is reported in kilometers per day.

- Migration success is the percentage of tagged kelts detected downstream of BON (the most downstream dam in the FCRPS). It is calculated by dividing the number of tagged kelts that were detected on any of the autonomous arrays downstream of BON by the number of kelts tagged. This differs from survival because it does not take into account the detection probability of arrays.

\subsection{Fish Capture, Tagging, and Release}

The following sections describe the methods used to capture fish; associated record-keeping related to meeting permitting requirements for fish collection and handling; sampling; acoustic transmitter and passive integrated transponder (PIT)-tag implantation; fish recovery and holding; and release.

\subsubsection{Capture Sites}

Overall, six capture sites were used during the 2013 study. Steelhead kelts were collected from and tagged at five capture sites on four different tributaries of the Snake and Clearwater rivers (Figure 1.2). Steelhead kelts with clipped or intact adipose fins were also collected from the LGR JFF and tagged during the study.

\subsubsection{Federal and State Permitting}

Records were kept on all kelts handled and tagged for permit accounting. Tagging was conducted in conjunction with routine sampling efforts at LGR and tributary sites conducted by various state and Tribal agencies in order to minimize handling impacts on the fish. A federal scientific take permit (permit number 14-13-PNNL86) was authorized for this study by the National Oceanic and Atmospheric Administration (NOAA) Fisheries Hydropower Division's FCRPS Branch and administered by NOAA. 
Scientific collection permits were also obtained from three state fish and wildlife management agencies: the Washington Department of Fish and Wildlife (permit number 13-081), the Idaho Department of Fish and Game (permit number F-12-03-13), and the Oregon Department of Fish and Wildlife (permit number 17940). All permit requirements and guidelines were met, and reports of collection and release were reported to each agency. All animals used in this study were handled in accordance with federal guidelines, and study protocols were approved by the PNNL Institutional Animal Care and Use Committee (protocol number 2013-02).

\subsubsection{Sampling Methods}

Kelts were removed from the separator at the LGR JFF and held in a 26,280-L (7.3- $\times 2.4-\times 1.5-\mathrm{m})$ holding tank for up to 24 hours before sampling. Tributary weirs were checked daily, and kelts were immediately sampled. All weirs except the George Creek weir were equipped with downstream migrant trap boxes, which were used with varying levels of success to capture kelts. Because of the lack of fish voluntarily moving into the downstream migrant trap boxes, most kelts tagged in the tributaries for this study were captured by the use of seine and/or dip nets upstream of tributary weirs.

Demographic information, including sex, maturational status (pre- or post-spawn), status of adipose fin (clipped or intact), and external physical condition (good, fair, or poor), were recorded for each fish captured. Fork length $(\mathrm{cm})$ and weight $(\mathrm{kg})$ were also measured for each individual.

Males were identified by their characteristically longer snout and the presence of a kype. Males were also typically thinner in profile than females. Females were identified by their blunt rounded snout, the absence of a kype, and their more round abdominal profile (Buelow 2011). Maturational status was determined by evidence, or the lack thereof, of previous spawning activity. Female steelhead were readily identified as kelts by their much more slender and compressed body profile when compared to the thick egg-laden abdomen of a pre-spawn female (Buelow 2011). The downstream direction of migration was often the best identifier of male kelts versus pre-spawn males. Abrasions, especially on the caudal and anal fins, served as additional evidence of previous spawning activity.

Kelts were assessed for condition by visual external evaluation using a method similar to that of Keefer et al. (2008) and Buelow (2011). Kelts were considered to be in good condition if they were active with very minor or no wounds, fungus, or injuries (Figure 2.1). Fair-condition kelts were active with minor to moderate wounds, fungus, or injuries (Figure 2.2). Poor-condition kelts had low activity levels and/or moderate to severe wounds, fungus, or injuries. Only good- and fair-condition kelts were selected for surgical implantation of acoustic transmitters because those kelts have been shown to be in better physiological health and the most likely to migrate (Wertheimer and Evans 2005; Buelow 2011). 


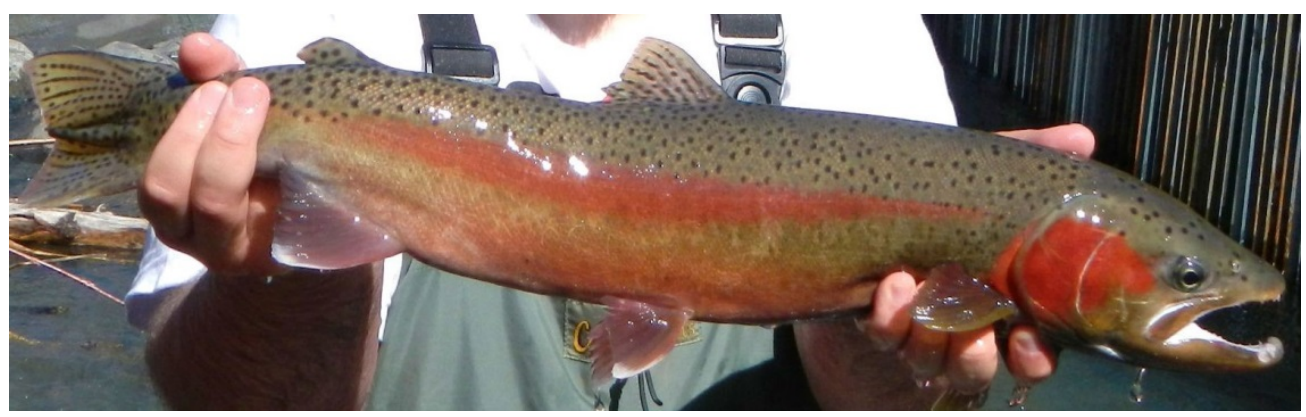

Figure 2.1. Photograph of a steelhead kelt that was in good condition at the time of tagging. Goodcondition kelts are typically active with very minor or no wounds, fungus, or injuries.

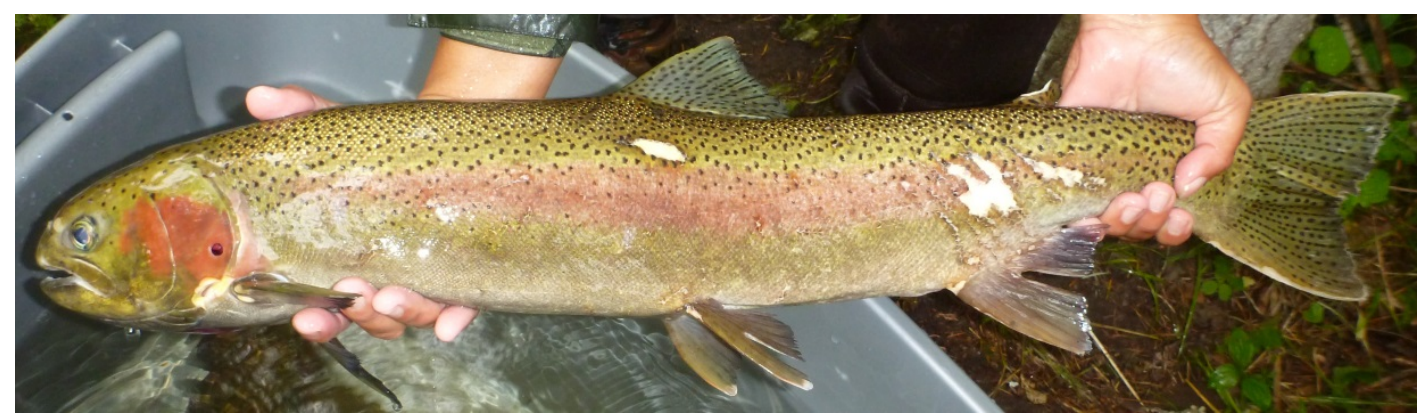

Figure 2.2. Photograph of a steelhead kelt that was in fair condition at the time of tagging. Faircondition kelts are typically active with minor to moderate wounds, fungus, or injuries.

\subsubsection{Implantation of Passive Integrated Transponder Tags and Acoustic Transmitters}

Prior to surgery, each kelt was anesthetized by the respective management agency at each capture site. Anesthetized fish were implanted with a 12-mm 134.2-kHz PIT tag (Biomark, Boise, Idaho) either in the dorsal sinus (fish collected from Asotin Creek, Potlatch River, and Fish Creek) or the pelvic girdle (fish collected from LGR and Joseph Creek) using a 12-gauge needle and syringe. PIT tag codes and corresponding fish information were uploaded to the PIT Tag Information System (PTAGIS) database (www.ptagis.org).

Each kelt selected for acoustic tagging was further anesthetized using a solution of 100-mg tricaine methanesulfonate (MS-222)/L of water buffered with a 200-mg/L solution of sodium bicarbonate until reaching Stage 4 anesthesia as described by Summerfelt and Smith (1990). Each kelt was then placed ventral side up on a foam surgery pad, and fresh river water (at tributary sites) or a maintenance dose of $50 \mathrm{mg}$ MS-222/L of water (at LGR) was pumped into the mouth of the kelt for the duration of the surgery ( 1.5-3 min).

A small incision of approximately $6 \mathrm{~mm}$ was made on the ventral side of the fish, halfway between the pectoral and pelvic girdles along the linea alba. A JSATS transmitter (Advanced Telemetry Systems, Inc., Insanti, Minnesota) was implanted into the coelom of each kelt. The acoustic transmitters were 11.5 $\mathrm{mm}$ long, $5.9 \mathrm{~mm}$ wide, and $4.3 \mathrm{~mm}$ high. The transmitters weighed $0.5 \mathrm{~g}$ in air. The nominal pulse rate interval for the JSATS transmitters used in this study was 4.2 seconds, and the expected tag life was 80 days. Different methods were used to implant acoustic transmitters in male and female kelts. For 
male kelts, the acoustic transmitter was inserted into the body cavity and the incision closed with two simple interrupted 3-0 Monocryl stitches (Ethicon, Rahway, New Jersey). For females, a barbed suture (V-loc 90, 4-0, Covidien, Mansfield, Massachusetts) was attached to the acoustic transmitter with epoxy (days to weeks prior to tag implantation). After the incision was made, the barbed suture was passed into the body cavity and out through the body wall of the fish. The transmitter was inserted though the incision, and the barbed suture was then pulled gently until the transmitter was flush against the interior surface of the body wall; the barbed suture was then cut, leaving a tail end of approximately $2 \mathrm{~mm}$ of suture outside the body to help anchor the transmitter to the body wall (Figure 2.3). The incision was then closed using two stitches in the same manner as done with the males. The barbed suture method was used to decrease possible transmitter loss in females due to post-spawn swelling of the vent and the small size of the acoustic transmitter.

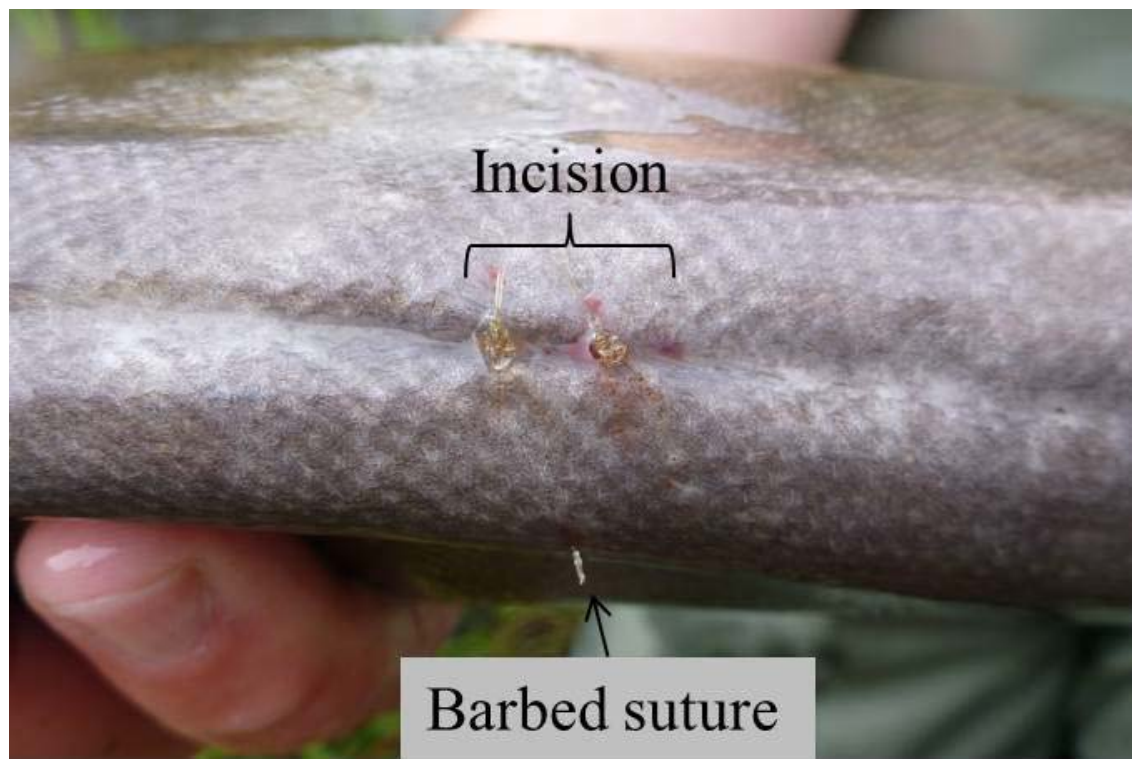

Figure 2.3. Photograph of the incision area of a female steelhead kelt implanted with an acoustic transmitter. The acoustic transmitter was attached to a barbed suture and then anchored to the body wall to decrease possible transmitter loss due to post-spawn swelling of the vent and the small size of the acoustic transmitter.

\subsubsection{Recovery, Holding, and Release}

After surgery, kelts tagged at LGR were held overnight in a 17,568-L (6.1- × 2.4- $\times 1.2-\mathrm{m})$ holding tank at the LGR JFF. The following morning, they were released into the river using a flume pipe leading directly from the holding tank to the LGR tailrace. Kelts tagged at tributary sites were allowed to recover in a 114-L plastic tote full of fresh river water. Kelts were released after regaining equilibrium and normal activity level ( 10-20 min).

\subsection{Detection of Tagged Fish}

Two types of receiver arrays, cabled and autonomous, were deployed to detect fish tagged with acoustic transmitters as they passed downstream through the study area between the upstream end of the LGR pool (rkm 743) and downstream of BON at rkm 113 (Table 2.1). The cabled receiver arrays at 
LGR, LGS, and LMN were used to estimate the route of passage at the dam using three-dimensional (3D) tracking and last-detection data (Deng et al. 2011). Dam passage survival was estimated from detection on the cabled receiver arrays to the second downstream autonomous receiver array (generally in the reservoir of the next downstream dam). The autonomous receiver array that marked the downstream boundary of the tailrace (located 1 to $2 \mathrm{~km}$ downstream from the dam) was not used for survival estimation because kelts that died during dam passage may be detected on these arrays and falsely classified as alive. The global positioning system (GPS) positions of individual dam-face hydrophones, autonomous receivers, and fish release locations are presented in Appendix A. All cabled hydrophones and autonomous receivers were tested in the acoustic tank located in the PNNL Bio-Acoustics and Flow Laboratory (Deng et al. 2010) prior to their deployment. The Bio-Acoustics and Flow Laboratory is accredited by The American Association for Laboratory Accreditation (A2LA) to ISO/IEC 17025:2005, which is the international standard for calibration and testing laboratories.

Table 2.1. Total river kilometers from each acoustic receiver array to the mouth of the Columbia River, along with the description, location, name, and function of each array deployed in 2013. Array Name is a concatenation "CR" for Columbia River, and the distance from the mouth of the Columbia River. For reference, the mouth of the Snake River is located at rkm 522.

\begin{tabular}{llll}
\hline \multicolumn{1}{c}{ Array Description } & \multicolumn{1}{c}{ Location } & Array & \multicolumn{1}{c}{ Array Function } \\
\hline LGR Pool Upper Boundary & Red Wolf Bridge & CR743 & Detect tagged fish entering LGR pool \\
LGR Forebay & $1 \mathrm{~km}$ upstream LGR & CR696 & Detect tagged fish entering LGR forebay \\
LGR Dam Face & LGR & CR695 & Regroup fish for route-specific assignments \\
LGR Tailrace & $2 \mathrm{~km}$ downstream LGR & CR693 & Detect tagged fish to estimate egress rate \\
LGS Forebay & $1 \mathrm{~km}$ upstream LGS & CR636 & Detect tagged fish entering LGS forebay \\
LGS Dam Face & LGS & CR635 & Regroup fish for route-specific assignments \\
LGS Tailrace & $1 \mathrm{~km}$ downstream LGS & CR634 & Detect tagged fish to estimate egress rate \\
LMN Pool & Ayer's Boat Basin & CR602 & Detect tagged fish migrating through LMN pool \\
LMN Forebay & $1 \mathrm{~km}$ upstream LMN & CR590 & Detect tagged fish entering LMN forebay \\
LMN Dam Face & LMN & CR589 & Regroup fish for route-specific assignments \\
LMN Tailrace & $2 \mathrm{~km}$ downstream LMN & CR587 & Detect tagged fish to estimate egress rate \\
IHR Pool & $24 \mathrm{~km}$ upstream IHR & CR562 & Detect tagged fish migrating through IHR pool \\
IHR Forebay & $1 \mathrm{~km}$ upstream IHR & CR539 & Detect tagged fish entering IHR forebay \\
Mouth of Snake River & $3 \mathrm{~km}$ upstream CR & CR525 & Detect tagged fish migrating out of SR \\
BON Forebay & $2 \mathrm{~km}$ upstream BON & CR236 & Detect tagged fish entering BON forebay \\
Lower CR & Knapp & CR152 & Detect tagged fish migrating through Lower CR \\
Lower CR & Martin Bluff & CR126 & Detect tagged fish migrating through Lower CR \\
Lower CR & Kalama & CR113 & Detect tagged fish migrating through Lower CR \\
\hline CR = Columbia River; SR = Snake River; LGR = Lower Granite Dam; LGS = Little Goose Dam; LMN = Lower \\
Monumental Dam; IHR = Ice Harbor Dam; BON = Bonneville Dam.
\end{tabular}

\subsubsection{Cabled Receiver Arrays}

The cabled receivers were acquired from Advanced Telemetry Systems, Inc. Each cabled receiver consisted of a computer, data-acquisition software, digital signal-processing cards with fieldprogrammable logic gate array (DSP+FPGA), GPS card, and a four-channel signal-conditioning receiver 
with gain control, hydrophones, and cables. The software that controls data acquisition and signal processing is the property of the USACE.

Cabled receiver arrays were deployed along the upstream face of LGR, LGS, and LMN to detect kelts tagged with acoustic transmitters as they approached and passed the dams. Cabled receiver arrays at all dams consisted of hydrophones mounted on each main pier. Hydrophones for each cabled receiver were deployed on trolleys in pipes attached to the main piers at the powerhouse and spillways in a known fixed geometry. The fixed geometry and precisely synchronized clocks allowed the tag position to be computed from the differences in arrival timing among hydrophones of each transmitted tag message. Two hydrophones were deployed at each main pier, one at a shallow elevation and the other at a deep elevation to provide acceptable geometries for tracking tagged fish in three dimensions and to assign routes of passage through the dam. The elevations and physical locations (latitude and longitude) of each cabled receiver hydrophone are presented in Appendix A.

One- and two-cluster arrays were deployed in the forebay of LGR and LMN, respectively. These arrays were deployed on the bottom of the reservoir approximately $50 \mathrm{~m}$ upstream from the spillway weir to assist 3D tracking of kelts as they approached each dam. Each cluster array consisted of a non-planar configuration of four hydrophones attached to a metal frame. Hydrophones were cabled to receivers, which were housed in trailers on the forebay deck of the dams, with the exception of LGR where some of the receivers were housed in the gallery of the dam.

\subsubsection{Autonomous Receiver Arrays}

Autonomous acoustic telemetry receivers were deployed in arrays at strategic sites throughout the lower Snake and Columbia rivers (Figure 1.1). Fifteen arrays of autonomous receivers were used in this study. An array is defined as a group (between 2 and 10 receivers) of autonomous acoustic receivers deployed across the entire width of a river to detect tagged fish that move past the array. Most arrays consisted of receivers deployed within $120 \mathrm{~m}$ of each other and less than $90 \mathrm{~m}$ from the shore.

Autonomous receiver arrays were located in the forebays of LGR, LGS, LMN, IHR, and BON and in the tailraces of LGR, LGS, and LMN. Additional mid-reservoir arrays were also located in the pools of LMN, and IHR. An array was deployed near the upstream extent of the LGR pool, and three arrays were deployed downstream of BON. See Appendix A for approximate GPS coordinates of autonomous receivers used in this study.

Autonomous receivers were rigged with the configuration shown in Figure 2.4 and presented in detail by Titzler et al. (2010). In brief, a rope with three floats connected the receiver housing to an acoustic release device (Model 111, InterOcean Systems, Inc., San Diego, California). A second rope connected the acoustic release device to a steel anchor and the rope length (up to $2 \mathrm{~m}$ ) was adjusted to account for water depth and substrate condition.

Autonomous receivers were retrieved by boat and downloaded at least once per month. A preactivated receiver was immediately deployed in the same location as the recovered receiver (Snake River) or data from the receiver were downloaded and the receiver was redeployed in the same location (Columbia River). The data were downloaded from the memory card to a laptop computer and checked 
to verify that data were collected during the entire deployment, records were continuous, and records included time stamps and tag detections. The memory card was replaced and batteries changed when needed.

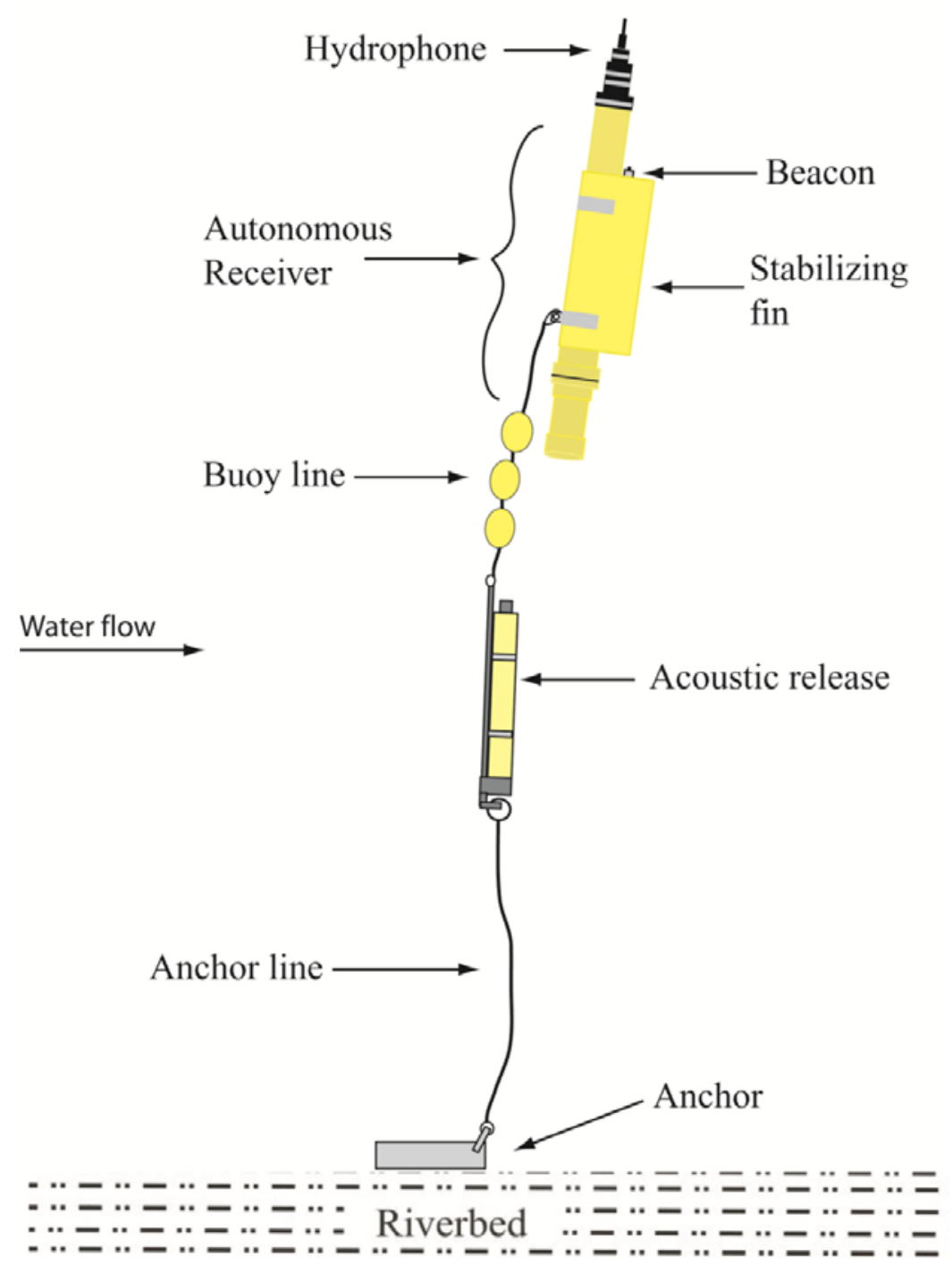

Figure 2.4. The autonomous acoustic receiver system used in 2013, including the hydrophone, acoustic receiver, acoustic release, and anchor.

\subsection{Data Processing and Validation}

Data collected by the cabled hydrophones were encoded candidate messages saved in binary timedomain waveform files (Weiland et al. 2011). The waveform files were then processed by a decoding utility (JSATS decoder developed by the USACE and PNNL) that identifies valid tag signals and computes the tag code using binary phase shift keying, a digital-modulation technique that transmits messages by altering the phase of the carrier wave. The decoding process also computed the time of arrival for the tag message at each hydrophone. Several filtering algorithms were then applied to the raw results from the decoding utilities to exclude spurious data and false positives. 
To produce accepted detection events, raw data were processed through a series of filters that removed detections arising from noise. The output of the filtering process is a data set that summarizes accepted tag detections for all times and locations where hydrophones were operating. Each unique event record included a basic set of fields that indicated the fish identification, the event first and last detection time, the location of detection, and the number of hits detected within the event. Additional fields were added to an event record to capture specialized information, where available. An example is route of passage, which is assigned a value for the event that immediately precedes dam passage based on the spatial tracking of tagged fish movements to the location of last detection on the cabled receiver array.

Fish were tracked in three-dimensions within the cabled array reception areas in the near-dam forebays of LGR, LGS, and LMN. Multiple receptions of messages within an event were used to triangulate successive tag positions relative to hydrophone locations. Dam passage routes were assigned based upon the paths taken by fish during the final event prior to dam passage.

\subsection{Statistical Methods}

The statistical methods included tests of assumptions and estimation of dam-passage survival, travel times, and estimates of the population abundance arriving at and passing LGR.

\subsubsection{Tests of Assumptions}

Several assumptions of the virtual single-release survival model could be readily tested. Table 2.2 describes survival model assumptions and subsequent sections describe assumption testing conducted in 2013.

\subsubsection{Tag-Life Study}

All tags used for this study were located at PNNL prior to the beginning of tagging (11 April 2013), including any leftover tags from the 2012 study. A total of 45 tags (20 tags from 2012 and 25 tags from 2013) were randomly selected to assess tag failure; premature tag failure would violate Assumption A6 (see Table 2.2). The reception of messages from these tags was continuously monitored from their activation to their failure in water. The failure times were fit with the four-parameter vitality model of Li and Anderson (2009), the two- or three-parameter Weibull model, or a non-parametric model. Because the possibility of acoustic-tag failure before the fish exits the study area depends on travel time relative to battery life, we plotted tag-life curves and the cumulative percentage of tags passing the most downstream survival-detection array (rkm 126) as a function of time since tag activation.

\subsubsection{Survival Estimation}

A virtual single-release study design was used to estimate overall dam passage and route-specific survival at each dam that was fitted with a cabled array and reach survivals for river reaches located between the dams. Virtual release groups, which are groupings of fish based on detection at a similar location independent of when or where those fish were released, were formed at the array that marked the upstream boundary of each reach. For route-specific survival estimation, virtual release groups consisted of all fish that passed a specific dam through the same route (i.e., JBS, spillway weir, traditional spill, 
turbines). Survival from the array that marked the upstream boundary of the reach to the next downstream (primary) array was estimated for each virtual release group. Detections of fish on the primary array and all cabled and autonomous arrays located downstream from the primary array (secondary arrays) were used to construct detection histories for each fish in the virtual release group. With two opportunities for detection, the possible detection histories for tagged fish were as follows:

$00=$ not detected on the primary or secondary arrays

$10=$ detected on the primary array but not on any of the secondary arrays

01 = detected on at least one secondary array but not on the primary array

$11=$ detected on both the primary array and on at least one secondary array.

Table 2.2. Assumptions of the virtual single-release model and tests of the assumptions (based on Skalski et al. 2010).

Assumption

A1. Individuals marked for the study are a representative sample from the population of inference.

A2. Survival and recapture probabilities are not affected by tagging or sampling. That is, tagged animals have the same probabilities as untagged animals.

A3. All sampling events are "instantaneous." That is, sampling occurs over a negligible distance relative to the length of the intervals between sampling events.

A4. The fate of each tagged individual is independent of the fate of all others.

A5. All tagged individuals alive at a sampling location have the same probability of surviving to the next sampling location.

A6. All tagged individuals alive at a sampling location have the same probability of being detected at that location.

A7. All tags are correctly identified and the status of each kelt (i.e., alive or dead) is correctly assessed.

A8. The virtual release group is constructed of tagged fish known to have passed through the dam.

A9. All fish arriving at the dam have an equal probability of inclusion in the virtual release group, independent of the passage route through the dam.
Test

Compare run timing distributions for the test fish versus the steelhead kelt monitoring data. Compare fish size and other fitness measures between tagged fish and runat-large.

No test; commonly accepted as true in tagging studies. Tag burdens were very low in this study, and acoustic detections of kelts do not involve physical recapture of individuals.

No test; the time a tagged fish spends at a sampling array is relatively brief compared to the time of travel between arrays.

No test; commonly accepted as true in tagging studies.

No test; the high detection probabilities present in acoustic-tag studies preclude testing.

No test; this assumption is satisfied by placing hydrophone arrays across the breadth of the river so that all fish, regardless of location, have the same probability of detection. Lab-derived tag-life data will be used to assess this assumption.

Laboratory tag-life assessments are conducted because tag loss or failure would violate this basic assumption. In addition, survival arrays were located sufficiently far downstream from the dams to minimize the probability of dead kelts being detected and incorrectly identified as alive.

A double-detection array in the forebay increases detection probabilities close to 1.0 and will be used to test for homogeneous detection rates.

This assumption is met by having very high detection probabilities on dam-face arrays. Thus, we will estimate array detection probabilities. 
The detection history of each virtual release group was loaded into SURPH Version $3.5 .2^{1}$ to estimate overall dam passage, route-specific, and reach survivals as well as detection probabilities for each array. It is possible for model-derived survival estimates to exceed 1.0, because estimates of survival from Cormack-Jolly-Seber single-release models are random variables subject to sampling variability. This is particularly likely when true survival probabilities are close to 1.0 or when sampling variability is high (Muir et al. 2001; Smith et al. 2002; Skalski et al. 2009).

\subsubsection{Determination of Passage Proportion}

Passage proportions were calculated for traditional spill, spillway weirs, turbines, and the JBS. For fish that entered the JBS, the PIT-tag detection system was used to provide a tally of that passage abundance, with the assumption of $100 \%$ detection efficiency. Routes of passage for fish that passed through the traditional spillways, spillway weirs, and turbines were determined by 3D tracks and last detection location based on acoustic telemetry data.

\subsubsection{Estimation of Passage Times and Travel Rates}

Travel times associated with forebay residence, tailrace egress, and project passage were calculated for each kelt tagged with an acoustic transmitter that passed LGR, LGS, and LMN in 2013 and was detected on both the upstream and downstream arrays. Travel rates were also calculated for all other river reaches encompassed by receiver arrays.

\subsubsection{Estimation of Population Abundance Arriving at Lower Granite Dam}

Assuming the proportion of tributary-tagged kelts we observed passing LGR through the JBS was representative of all kelts originating from upstream of LGR, the annual kelt abundance at LGR was estimated as:

$$
\widehat{N}_{L G R}=\frac{n_{\mathrm{m}}+n_{\mathrm{u}}}{p_{J B S}}
$$

where $\quad \widehat{N}_{L G R}=$ marked and unmarked kelt population estimate at LGR

$n_{\mathrm{m}}=$ total number of marked (adipose-clipped) kelts sampled at the LGR JFF separator

$n_{\mathrm{u}}=$ total number of unmarked (unclipped) kelts sampled at the LGR JFF separator (including recaptures)

$p_{J B S}=$ proportion of acoustic-tagged kelts that passed LGR through the JBS.

We attempted to verify the precision of this estimate by calculating the abundance of unmarked kelts using the Lincoln-Petersen mark-recapture method (Petersen 1896; Lincoln 1930) and comparing it to the unmarked kelt abundance estimate obtained using the equation $\widehat{N}_{u}=\frac{n_{\mathrm{u}}}{p_{J B S}}$ (similar to the approach described above). To estimate unclipped kelt abundance using the Lincoln-Petersen method, kelts captured and tagged with acoustic transmitters and PIT tags at tributary weirs were used as the first sample, and unclipped acoustic-tagged kelts that were sampled at the LGR JFF separator were used as the second sample.

\footnotetext{
${ }^{1}$ http://www.cbr.washington.edu/paramest/surph/ (December 2012).
} 


$$
\begin{gathered}
\widehat{N}_{\text {trib }}=\frac{n_{1} n_{2}}{m_{2}} \\
\widehat{S E}=\sqrt{\frac{\left(n_{1}+1\right)\left(n_{2}+1\right)\left(n_{1}-m_{2}\right)\left(n_{2}-m_{2}\right)}{\left(m_{2}\right)^{2}\left(m_{2}+2\right)}}
\end{gathered}
$$

where $\quad \widehat{N}_{\text {trib }}=$ unmarked kelt population estimate at the time of tagging

$n_{1}=$ number of unclipped kelts caught, marked, and released at tributary weirs

$n_{2}=$ total number of unclipped kelts that passed through the LGR JFF and were sampled on the separator (including recaptures)

$m_{2}=$ number of acoustic-tagged kelts sampled in the LGR JFF (i.e., recaptures)

\subsection{Dam-Passage Characteristics}

We examined passage characteristics for all kelts that passed each dam in the system relative to flow and time of day.

\subsubsection{Dam Passage versus Flow}

The cross-dam distributions of kelt passage at LGR, LGS, and LMN were analyzed using data collected from the cabled receiver arrays. Each cross-dam distribution was calculated by dividing the number of kelts that passed through each opening in the dam (e.g., Turbine Unit 1, Spill Bay 5, etc.) by the total number of fish that passed through the dam. The proportion was multiplied by 100 for presentation as a percentage. Percentages were then plotted against the location of each opening in the dam. The percentage of flow that passed through each opening in the dam during the time when tagged kelts passed each dam (LGR, 14 April to 17 June; LGS, 17 April to 22 June; LMN, 19 April to 24 June) was also plotted.

\subsubsection{Diel Distribution}

The diel distributions of kelt passage through each dam were determined using the cabled receiver array detections at LGR, LGS, and LMN. For each cabled array, the number of kelts last detected on the cabled array during each hour of the day was divided by the total number of kelts that passed through the dam. This proportion was multiplied by 100 for presentation as a percentage. Plots of the percentage of kelts last detected each hour were created for each cabled receiver array. Bars indicating approximate hours of darkness were placed beginning 1 hour after sunset and ending 1 hour before sunrise. Average sunrise and sunset times for each cabled receiver array were calculated from the sunrise and sunset times of the first and last day of detection for each cabled receiver array, based on data downloaded from the U.S. Naval Observatory website (available at http://aa.usno.navy.mil/data/docs/RS OneYear.php). Average sunrise and sunset times for Pullman, Starbuck, and Kahlotus, Washington, were used for the cabled receiver arrays at LGR, LGS, and LMN, respectively. 


\subsection{Results}

The study results related to environmental conditions, survival estimates, and fish passage summaries are presented in the following sections.

\subsection{Environmental Conditions}

Total discharge and spill discharge at FCRPS dams in 2013 was generally less than the 10-year average (2003-2012), with the exception of a brief period in mid-May (Appendix D). For the entire study period, from the time the first fish was released to the time the last fish was detected in the Snake River (11 April through 27 June 2013), total daily discharge in the Snake River (as measured at LGR) ranged from 40.4 to $137.3 \mathrm{kcfs}$ with a mean of $66.0 \mathrm{kcfs}$ (Table 3.1; Figure C.1). Spillways were in use during the entire study period at all three FCRPS dams outfitted with cabled receivers in the Snake River, and the mean percentage spill during that time ranged from $30.3 \%$ at LGS to $41.2 \%$ at LMN (Table 3.1). Water temperatures in the Snake River fluctuated around or slightly above the 10-year average (2003-2012) during the study period (Appendix E).

Table 3.1. Mean, maximum, and minimum discharge values (kcfs) and percentage spill at Lower Granite (LGR), Little Goose (LGS), and Lower Monumental (LMN) dams for the time period between the tagging of the first kelt (11 April 2013) and the last detection of a kelt at any acoustic array in the Snake River (27 June 2013). Also shown are the 10-year averages (2003-2012) for the same dates. All discharge data were obtained from the DART website (Data Access in Real Time; http://www.cbr.washington.edu/dart/).

\begin{tabular}{lcccc|cc}
\hline & \multicolumn{2}{c}{2013} & \multicolumn{2}{c}{$10-$ Year Average } \\
\hline & $\begin{array}{c}\text { Mean Discharge } \\
(\mathrm{kcfs})\end{array}$ & $\begin{array}{c}\text { Max. Discharge } \\
(\mathrm{kcfs})\end{array}$ & $\begin{array}{c}\text { Min. Discharge } \\
(\mathrm{kcfs})\end{array}$ & $\begin{array}{c}\text { Mean \% } \\
\text { Spill }\end{array}$ & $\begin{array}{c}\text { Mean Discharge } \\
(\mathrm{kcfs})\end{array}$ & $\begin{array}{c}\text { Mean \% } \\
\text { Spill }\end{array}$ \\
\hline LGR & 66.0 & 137.3 & 40.4 & 33.3 & 96.2 & 28.4 \\
LGS & 64.9 & 130.1 & 40.8 & 30.3 & 93.4 & 27.1 \\
LMN & 66.9 & 131.5 & 41.5 & 41.2 & 95.6 & 28.3 \\
\hline
\end{tabular}

\subsection{Kelt Migration Timing and Demographics}

Tagging began on 12 April 2013 at LGR and continued until 17 June 2013 (Table 3.2). Kelts were captured and tagged at Asotin Creek, Potlatch River, and Joseph Creek between 11 April and 19 May 2013, and tagging at Fish Creek occurred between 22 May and 13 June 2013. After tagging began, kelts were sampled throughout their migration at all tagging sites to ensure our sample represented all stages of the run.

Functionality of the weirs at all tributary sites was related to spring runoff, and kelts were captured only when the water levels were low enough to allow for operation and maintenance of the weirs. High runoff conditions in the Potlatch River and Fish Creek delayed the onset of tagging; however, after 
Table 3.2. Dates of first and last kelt captured and tagged at Lower Granite Dam (LGR), Asotin Creek, Potlatch River, Joseph Creek, and Fish Creek, and the dates when 10\%, 25\%, 50\%, 75\%, and 90\% of the kelt at each location had been tagged.

\begin{tabular}{|c|c|c|c|c|c|c|c|c|c|c|}
\hline \multirow[b]{2}{*}{ Location } & \multirow{2}{*}{$\begin{array}{c}\text { Kelts } \\
\text { Tagged }\end{array}$} & \multirow{2}{*}{$\begin{array}{c}\text { First } \\
\text { Capture }\end{array}$} & \multirow{2}{*}{$\begin{array}{c}\text { First } \\
\text { Tagging }\end{array}$} & \multicolumn{5}{|c|}{ Percentage of Fish Tagged by Date } & \multirow{2}{*}{$\begin{array}{c}\text { Last } \\
\text { Tagging }\end{array}$} & \multirow[t]{2}{*}{ Last Capture } \\
\hline & & & & $10 \%$ & $25 \%$ & $50 \%$ & $75 \%$ & $90 \%$ & & \\
\hline LGR & 316 & 7 April & 12 April & 29 April & 6 May & 12 May & 21 May & 1 June & 17 June & 10 July \\
\hline Asotin Creek & 50 & $21 \mathrm{Feb}$ & 11 April & 12 April & 12 April & 16 April & 22 April & 23 April & 24 April & 28 May \\
\hline Potlatch River & 17 & 24 April & 25 April & 25 April & 26 April & 3 May & 5 May & 8 May & 15 May & 29 May \\
\hline Joseph Creek & 63 & 15 March & 11 April & 11 April & 12 April & 18 April & 23 April & 13 May & 19 May & 7 June \\
\hline Fish Creek & 41 & 20 May & 22 May & 23 May & 24 May & 2 June & 7 June & 9 June & 13 June & 28 June \\
\hline
\end{tabular}


tagging began at all tributary sites, flows were low enough to allow continuous operation of all weirs for the remainder of the tagging season. The timing of kelt capture at each collection site and the timing of tagging for this study are presented in Appendix F.

Although untagged kelts were first collected by Nez Perce personnel from the JFF at LGR on 7 April, the period of passage at LGR, LGS, and LMN for kelts implanted with acoustic transmitters was from 14 April through 24 June 2013 (Table 3.3). The date by which 50\% of kelts had passed each dam ranged from 28 April at LGR to 15 May at LMN. The majority (90\%) of tagged kelts passed through all three Snake River dams by early June, although several kelts were detected at autonomous receiver arrays in the lower Columbia River in early July.

Kelts implanted with acoustic transmitters ranged in fork length from 48.3 to $90.0 \mathrm{~cm}$. Median fork length was smaller for males $(53.2 \mathrm{~cm}$ to $70.5 \mathrm{~cm})$ than for females at all sites $(62.0 \mathrm{~cm}$ to $79.0 \mathrm{~cm}$; Table 3.4). Kelts collected and tagged at Fish Creek, which supports what is considered a B-run steelhead population, were generally larger than fish tagged at other sites. Females at all sites (1.7 kg to $3.6 \mathrm{~kg}$ ) were typically heavier than males ( $1.3 \mathrm{~kg}$ to 2.8 ; Table 3.4$)$. Overall, $46.5 \%$ ( $n=147 \mathrm{of} 316)$ of the kelts tagged at LGR had a clipped adipose fin, indicating they were of hatchery origin and $53.5 \%$ ( $n=169$ of 316) had an intact adipose fin suggesting they were of wild origin. These percentages were similar to those of all the fish handled at LGR (i.e., 40.0\% clipped adipose fin [ $n=366$ of 914 ] and $60.0 \%$ intact adipose fin [ $n=548$ of 914]). Only 1 of 171 kelts (0.6\%) tagged in tributaries had a clipped adipose fin; all others had an intact adipose fin.

\subsection{Estimates of Survival Rates}

Migration success rates, reach survival estimates, passage proportions, and route-specific survival estimates for kelts tagged with acoustic transmitters that passed through the FCRPS in 2013 are presented below.

\subsubsection{Migration Success Through the FCRPS}

Overall, 133 of 487 (27.3\%) steelhead kelts implanted with JSATS transmitters were detected on the array located in the tidal freshwater portion of the Columbia River estuary at Martin Bluff (rkm 126), indicating successful migration through the FCRPS. Of the fish that successfully migrated, $40.6 \%$ ( $n=$ 54 ) had a clipped adipose fin (denoting hatchery origin) and $59.4 \%(n=79)$ had an intact adipose fin. The migration success rate for kelts tagged at LGR with a clipped adipose fin was 36.5\% ( $n=54$ of 148), and 31.4\% ( $n=53$ of 169) for kelts with an intact adipose fin. The migration success rate of fish tagged in the tributaries was $16.4 \%(n=28$ of 171$)$. Males had a higher migration success rate $(33.9 \% ; n=37$ of 109 ) than females (25.4\%; $n=96$ of 378). Kelts in good and fair condition at the time of tagging differed in their migration success rates; kelts in good condition migrated successfully at a rate of 33.8\% ( $n=124$ of 367), whereas 7.5\% ( $n=9$ of 120) of fair condition kelts were detected at Martin Bluff (rkm 126). 
Table 3.3. Dates that the first and last kelts implanted with an acoustic transmitters passed Lower Granite (LGR), Little Goose (LGS), and Lower Monumental (LMN) dams and dates when 10\%, 25\%, 50\%, 75\%, and 90\% of the kelt had passed each dam.

\begin{tabular}{lcccccccc}
\hline & & First Kelt & \multicolumn{5}{c}{ Percentage of Kelt Passed by Date } \\
\cline { 6 - 7 } \multicolumn{1}{c}{ Dam } & Kelt Passed & Passed & $10 \%$ & $25 \%$ & $50 \%$ & Last Kelt \\
LGR & 144 & 14 April & 17 April & 23 April & 28 April & 21 May & 5 June & 17 June \\
LGS & 364 & 17 April & 28 April & 5 May & 13 May & 24 May & 6 June & 22 June \\
LMN & 294 & 19 April & 2 May & 11 May & 15 May & 25 May & 7 June & 24 June \\
\hline
\end{tabular}

Table 3.4. Sex ratios and total number of kelts tagged at Lower Granite Dam (LGR), Asotin Creek, Potlatch River, Joseph Creek, and Fish Creek along with total number tagged, median fork length (range), and weight (range) of males and females tagged at each site.

\begin{tabular}{lcccccc|ccc}
\hline & & & & \multicolumn{4}{c}{ Males } & \multicolumn{2}{c}{ Females } \\
\cline { 7 - 10 } \multicolumn{1}{c}{ Site } & M:F Ratio & Total & M:F Ratio & & & & & \multicolumn{2}{c}{ Fork Length } \\
$(\mathrm{cm})$ & Weight (kg) \\
\hline LGR & $0.3: 1$ & 316 & $0.4: 1$ & 90 & $57.5(49.0-77.0)$ & $1.4(0.96-3.47)$ & 226 & $62.0(52.0-84.0)$ & $1.7(0.82-4.30)$ \\
Asotin Creek & $0.3: 1$ & 50 & $0.2: 1$ & 8 & $55.4(48.3-65.2)$ & $1.3(1.24-2.16)$ & 42 & $66.4(52.3-76.7)$ & $2.2(1.14-3.14)$ \\
Potlatch River & $0.4: 1$ & 17 & $0.2: 1$ & 3 & $68.8(53.4-74.0)$ & $2.5(1.20-2.54)$ & 14 & $72.4(58.2-79.0)$ & $2.9(1.50-3.57)$ \\
Joseph Creek & $0.1: 1$ & 63 & $0.1: 1$ & 6 & $53.2(49.2-59.8)$ & $1.3(0.78-1.80)$ & 57 & $67.2(48.7-76.7)$ & $2.2(1.02-3.88)$ \\
Fish Creek & $0.1: 1$ & 41 & $0.1: 1$ & 2 & $70.5(59.0-82.0)$ & $2.8(1.64-3.96)$ & 39 & $79.0(59.0-90.0)$ & $3.6(1.66-5.90)$ \\
\hline
\end{tabular}




\subsubsection{Survival Estimates Through the FCRPS}

Survival to Red Wolf Bridge (rkm 743) varied by release location for kelts captured and tagged in the tributaries. Kelts tagged and released in Fish Creek (rkm 944; $n=41)$ had an estimated survival probability of 0.902 (SE $=0.046$ ) to Red Wolf Bridge. Those tagged and released in the East Fork Potlatch River ( $r k m ~ 835 ; n=17$ ) had the lowest probability of surviving to Red Wolf Bridge ( $S=0.824$; $\mathrm{SE}=0.093$ ) of all the tributary release groups. Conversely, kelts tagged and released in Joseph Creek ( $r k m 800 ; n=55$ ) had the highest probability of survival to Red Wolf Bridge ( $S=0.964$; SE $=0.025$ ). Finally, kelts from Asotin Creek (rkm 760; $n=45$ ) had an estimated survival probability of 0.956 (SE $=$ 0.031) to Red Wolf Bridge. Pooled together, kelts tagged in the tributaries had a 0.930 (SE $=0.020$ ) probability of surviving from release to Red Wolf Bridge.

Because of the large differences in the distance to Red Wolf Bridge from each tributary, differences in survival among tributary groups are more accurately depicted by survival/kilometer estimates. Kelts captured and tagged in Fish and Joseph creeks had the highest rates of survival per kilometer: 0.9995 and 0.9994, respectively. Survival per kilometer was similar among kelts captured and tagged in the East Fork Potlatch River (0.9979) and Asotin Creek (0.9973).

Dam passage survival (cabled receiver array to survival array located 27 to $59 \mathrm{rkm}$ downstream) was lowest at LGR $(S=0.657$; $\mathrm{SE}=0.042)$ and highest at $\mathrm{LMN}(S=0.891$; $\mathrm{SE}=0.018$; Table 3.5).

Evaluated on a per kilometer basis (reaches differed in length and for this reason, reach survival is best compared on a per kilometer basis; Table 3.5, Figure 3.1), survival was lowest at LGR $(S / \mathrm{km}=0.9929)$ and highest at LGS $(S / \mathrm{km}=0.9963)$. However, the opposite was true of survival in the immediate forebay (from $1 \mathrm{~km}$ upstream of the dam to the dam face) of the three dams. Forebay survival was lowest at LGS $(S=0.958$; $\mathrm{SE}=0.010)$ and highest at LGR $(S=0.978$; $\mathrm{SE}=0.013)$. Survival per kilometer was substantially lower in the immediate forebays of the three dams compared to any other reach (Figure 3.1). Survival per kilometer estimates exceeded 0.99 in all other reaches and was highest in the most upstream (tributary release to rkm 743 and rkm 743 to rkm 696) and downstream reaches (rkm 525 to rkm 236 and rkm 236 to rkm 126) of the study area.

The cumulative survival probability of all tagged kelts from the forebay array at LGS (rkm 636) to Martin Bluff (rkm 126) was 0.384 ( $\mathrm{SE}=0.025$; Figure 3.2). Relatively small sample sizes of fish collected and tagged at the tributary weirs and the large error associated with survival estimates for these groups precluded an in-depth comparison of cumulative survival probabilities by release location. However, we did observe some apparent differences in kelt survival to Martin Bluff (rkm 126) by tagging locations. Kelts tagged and released in the East Fork Potlatch River had the highest estimated survival $(S=0.500)$; however, this estimate included only 10 fish. Therefore, the error associated with this estimate was quite high ( $\mathrm{SE}=0.158$ ). The next highest cumulative survival probability to rkm 126 was observed for kelts collected and tagged at the LGR JFF ( $S=0.396$; SE $=0.029)$. The lowest cumulative survival probability was observed for kelts tagged in Fish Creek $(S=0.273$; $\mathrm{SE}=0.095)$. 


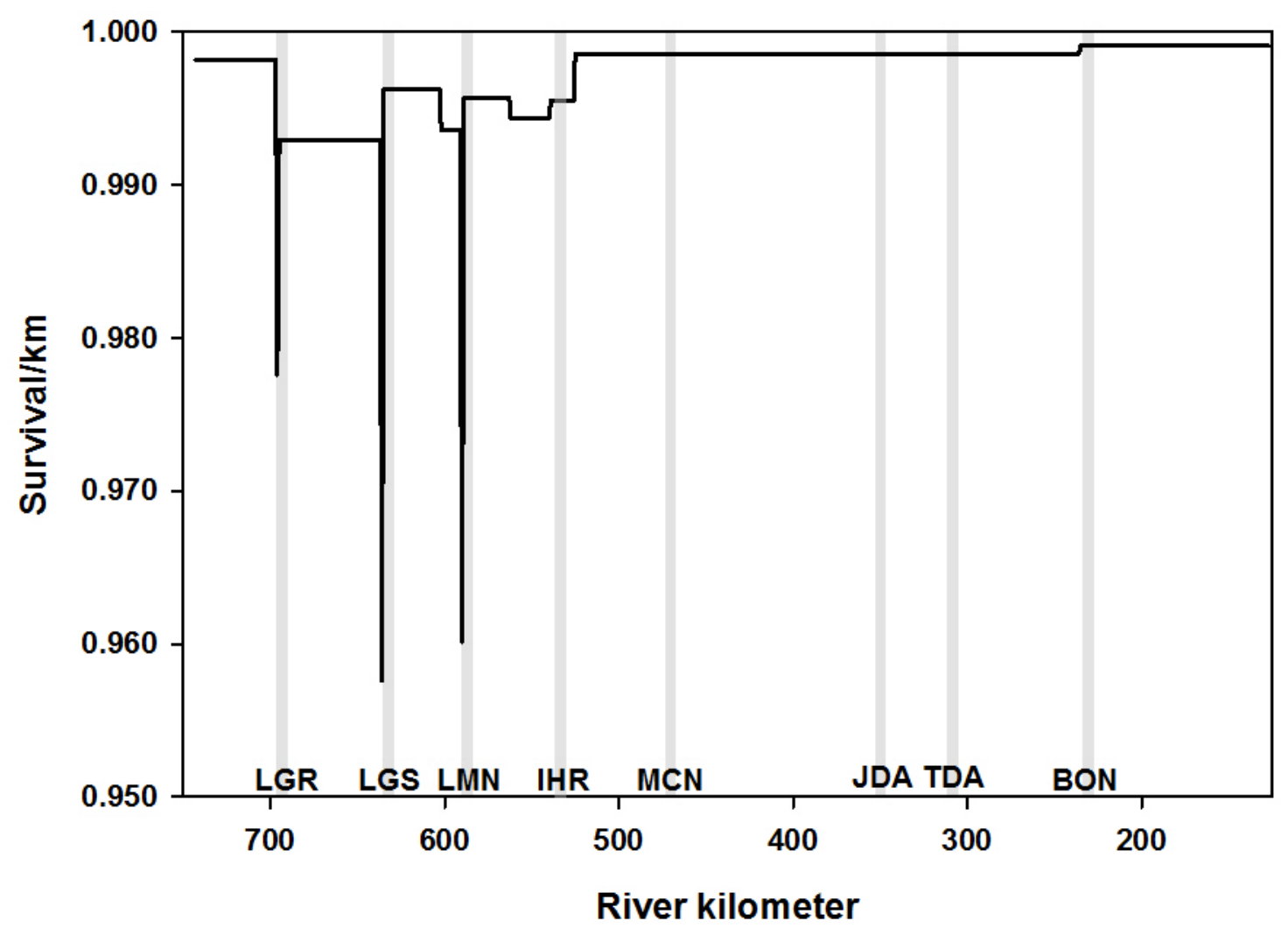

Figure 3.1. Standardized reach survival probability estimates for all tagged steelhead kelts detected in the Federal Columbia River Power System in 2013. 
Table 3.5. Reach survival estimate for all steelhead kelts implanted with acoustic transmitters that were detected in 2013 throughout the Federal Columbia River Power System (LGR = Lower Granite Dam, LGS = Little Goose Dam, LMN = Lower Monumental Dam, BON = Bonneville Dam).

\begin{tabular}{|c|c|c|c|c|c|c|}
\hline Location & $\begin{array}{c}\text { Upstream } \\
\text { Array }\end{array}$ & $\begin{array}{c}\text { Downstream } \\
\text { Array }\end{array}$ & Distance $(\mathrm{km})$ & $\mathrm{n}$ & Survival (SE) & Survival / km \\
\hline LGR reservoir & A1CR743 & A2CR696 & 47 & 147 & $0.919(0.023)$ & 0.9982 \\
\hline LGR forebay to LGR & A2CR696 & D1CR695 & 1 & 134 & $0.978(0.013)$ & 0.9780 \\
\hline LGR to LGS forebay & D1CR695 & A4CR636 & 59 & 131 & $0.657(0.042)$ & 0.9929 \\
\hline LGR tailrace to LGS forebay & A3CR693 & A4CR636 & 57 & 307 & $0.912(0.016)$ & 0.9984 \\
\hline LGS forebay to LGS & A4CR636 & D2CR635 & 1 & 375 & $0.958(0.010)$ & 0.9580 \\
\hline LGS to LMN forebay & D2CR635 & A7CR590 & 45 & 368 & $0.818(0.021)$ & 0.9955 \\
\hline LGS to mid-LMN reservoir & D2CR635 & A6CR602 & 33 & 368 & $0.886(0.017)$ & 0.9963 \\
\hline mid-LMN reservoir to LMN forebay & A6CR602 & A7CR590 & 12 & 326 & $0.926(0.015)$ & 0.9936 \\
\hline LMN forebay to LMN & A7CR590 & D3CR589 & 1 & 301 & $0.960(0.011)$ & 0.9600 \\
\hline LMN to IHR forebay & D3CR589 & A10CR539 & 50 & 293 & $0.782(0.024)$ & 0.9951 \\
\hline LMN to mid-IHR reservoir & D3CR589 & A9CR562 & 27 & 293 & $0.891(0.018)$ & 0.9957 \\
\hline Mid-IHR reservoir to IHR forebay & A9CR562 & A10CR539 & 23 & 262 & $0.878(0.021)$ & 0.9944 \\
\hline IHR forebay to Burbank & A10CR539 & A11CR525 & 14 & 230 & $0.939(0.016)$ & 0.9955 \\
\hline Burbank to BON forebay & A11CR525 & A12CR236 & 289 & 216 & $0.667(0.032)$ & 0.9986 \\
\hline BON forebay to rkm 126 & A12CR236 & A14CR126 & 110 & 144 & $0.910(0.024)$ & 0.9991 \\
\hline
\end{tabular}




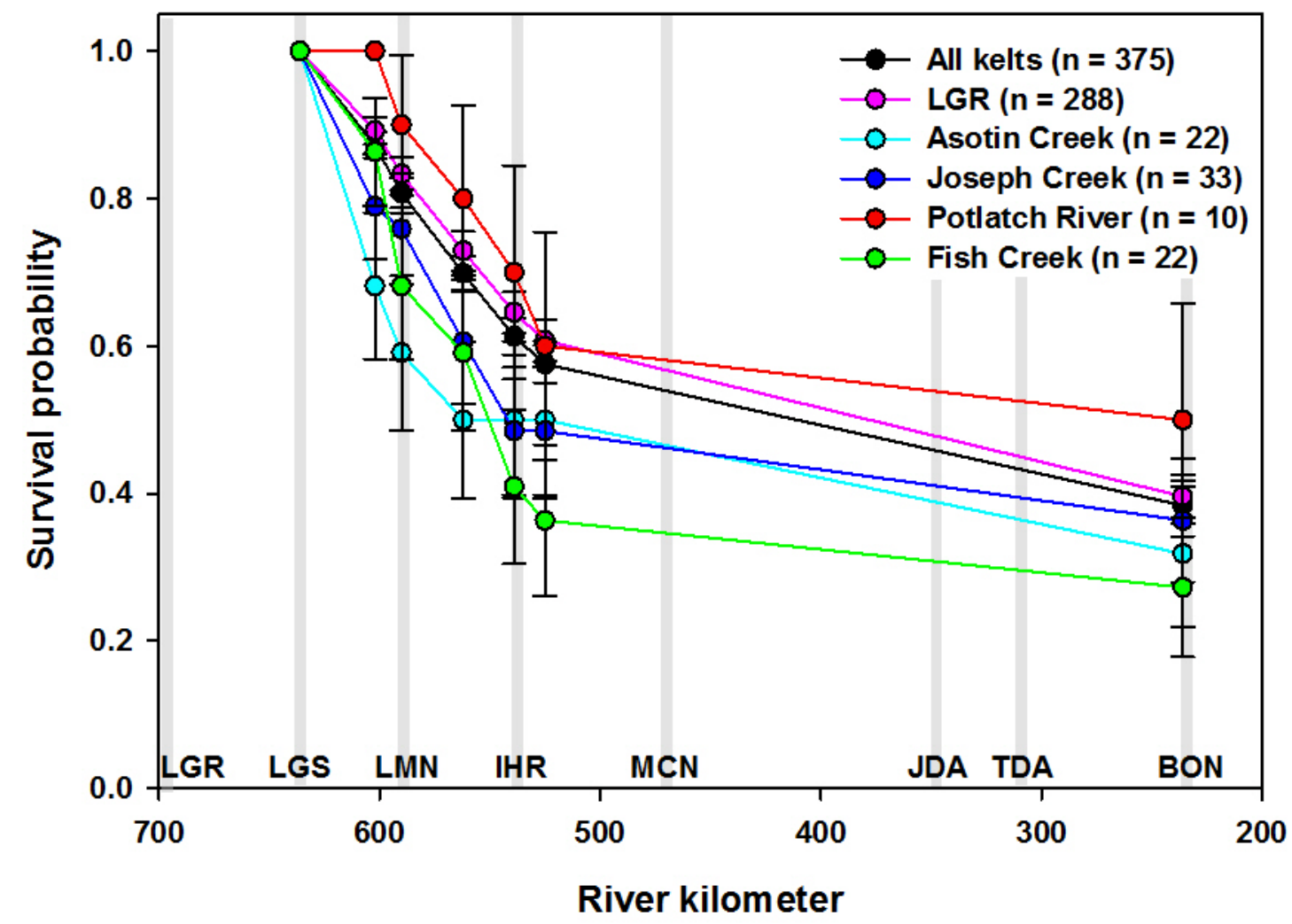

Figure 3.2. Cumulative survival probabilities of steelhead kelts from the Little Goose Dam (LGS) forebay array (rkm 636) to rkm 126 by tagging location (i.e., Lower Granite Dam Juvenile Fish Facility [LGR], Asotin Creek, Potlatch River, Joseph Creek, and Fish Creek). Survival probabilities are presented for the autonomous arrays that were deployed in the Federal Columbia River Power System in 2013 (LGR = Lower Granite Dam, LMN = Lower Monumental Dam, IHR = Ice Harbor Dam, MCN = McNary Dam, JDA = John Day Dam, TDA $=$ The Dalles Dam, BON = Bonneville Dam).

\subsubsection{Passage Proportions and Survival Estimates Through Each FCRPS Dam}

Overall, at each individual FCRPS dam monitored in this study, the largest proportion of steelhead kelts passed through the spillway (range: $86.9 \%$ [LGS] - 92.4\% [LGR]; Table 3.6). Specifically, spillway weirs were the most commonly used route of passage (>70\%) for tagged kelts at LGR, LGS, and LMN. The least-used route of passage was through the turbines at LGR and LGS, whereas the JBS was the least-used route at LMN. In total, less than $10 \%$ of tagged kelts that passed through each dam used a turbine or JBS route. A total of nine fish passed through LGR, LGS, and LMN ( $n=2,5$, and 2, respectively) but were not assigned to a specific route, so the route was denoted as "unknown." These fish may have passed through the navigation lock or other parts of the dam that were not equipped with cabled receivers (e.g., adult fish ladders). This is plausible because kelts were observed in the navigation locks of several FCRPS dams by the authors of this report on several occasions. In addition, seven kelts (1.4\% of total tagged fish) were detected at the forebay array after being detected at the dam face and were not detected again on that cabled receiver array or on any other downstream arrays, indicating these fish migrated upstream upon encountering the dam. Although these fish were included in the forebay-to- 
Table 3.6. Passage percentages and route-specific survival ( \pm SE) estimates of tagged kelts that passed through Lower Granite (LGR), Little Goose (LGS), and Lower Monumental (LMN) dams during the 2013 season. Single-release survival estimates were based on pooled data for each major route of passage (i.e., traditional spillway, spillway weir, turbine, juvenile bypass systems [JBS], unknown) at each dam. The number of kelts that passed through each route and the sample size used for survival estimation are shown for each route. These numbers do not always match because kelts tagged with transmitters from 2012 were included in passage proportion estimates but not in survival estimates due to tag life issues.

\begin{tabular}{|c|c|c|c|c|c|c|c|c|c|c|c|}
\hline \multirow[b]{2}{*}{ Dam } & \multirow[b]{2}{*}{ Measure } & \multicolumn{10}{|c|}{ Route } \\
\hline & & $n$ & Traditional Spill & $n$ & Spillway Weir & $n$ & Turbine & $n$ & JBS & $n$ & Unknown \\
\hline \multirow{2}{*}{ LGR } & Passage percentage & 18 & $12.5 \%$ & 115 & $79.9 \%$ & 2 & $1.4 \%$ & 7 & $4.9 \%$ & 2 & $1.4 \%$ \\
\hline & Survival (SE) & 17 & $0.706(0.111)$ & 105 & $0.667(0.046)$ & 2 & $1.000(0.000)$ & 6 & $0.333(0.193)$ & 1 & $0.000(0.000)$ \\
\hline \multirow{2}{*}{ LGS } & Passage percentage & 57 & $15.9 \%$ & 255 & $71.0 \%$ & 19 & $5.3 \%$ & 24 & $6.7 \%$ & 4 & $1.1 \%$ \\
\hline & Survival (SE) & 56 & $0.821(0.051)$ & 250 & $0.936(0.016)$ & 19 & $0.842(0.084)$ & 24 & $0.875(0.068)$ & 3 & $1.000(0.000)$ \\
\hline \multirow{2}{*}{ LMN } & Passage percentage & 47 & $16.0 \%$ & 209 & $71.1 \%$ & 20 & $6.8 \%$ & 16 & $5.4 \%$ & 2 & $0.7 \%$ \\
\hline & Survival (SE) & 46 & $0.826(0.056)$ & 206 & $0.927(0.018)$ & 19 & $0.842(0.084)$ & 16 & $0.938(0.061)$ & 2 & $0.500(0.354)$ \\
\hline
\end{tabular}


dam face survival estimates, they were not included in the dam passage or route-specific survival estimates. Appendix J outlines the routes of passage through multiple dams in the FCRPS taken by individual kelts.

The relatively small sample sizes of kelts that passed through turbine, JBS, or traditional spill routes precluded an in-depth comparison of survival probabilities by passage route at all dams. Only eight kelts (6.3\%) were included in the survival estimation for JBS and turbine routes at LGR, and only about $12 \%$ of kelts passed through the JBS and turbine routes at LGS and LMN. Kelts $(\mathrm{n}=2)$ that passed through the turbines at LGR survived to the LGS forebay array (rkm 636; $S=1.000$; $\mathrm{SE}=0.000$; Table 3.6); whereas the estimated survival to the LGS forebay array was just 0.333 (SE $=0.193$ ) for the six kelts that passed through the LGR JBS. The survival probability for kelts that passed the traditional spill and spillway weir routes at LGR was estimated to be 0.706 ( $\mathrm{SE}=0.111$ ) and 0.667 (SE =0.046), respectively. Kelts that passed through traditional spill routes had the lowest estimated survival at LGS (0.821; SE = $0.051)$ and at LMN (0.826; $\mathrm{SE}=0.056)$. Turbine-passed kelts experienced the next-lowest survival at LGS and LMN (at both dams $S=0.842$; SE $=0.084$ ). At LGS, the estimated survival probability was 0.875 ( $\mathrm{SE}=0.068$ ) for kelts that passed through the JBS and $0.936(\mathrm{SE}=0.016)$ for kelts that passed through the spillway weir. Conversely, at LMN, survival was highest through the JBS $(S=0.938$; $\mathrm{SE}=$ $0.061)$, followed by the spillway weir $(S=0.927$; $\mathrm{SE}=0.018)$.

\subsection{Passage Times and Travel Rates}

Passage times through forebays, tailraces, and projects, as well as travel rates for river reaches are reported below.

\subsubsection{Forebay Residence}

The distance between forebay and cabled receiver arrays was $1 \mathrm{~km}$ for each FCRPS dam investigated in this study. Median forebay residence times ranged from 1.35 hours (at LMN) to 1.92 hours (at LGS; Table 3.7). The shortest measured forebay residence time was 0.13 hours at LMN, and the longest was 89.47 hours, also at LMN. Plots of the frequency distribution of forebay residence times at LGR, LGS, and LMN demonstrate that most kelts ( 90\%) moved through the forebay in less than 14 hours (Figure 3.3). As previously mentioned, seven kelts were detected at the forebay array after being detected at the dam face of LGS and LMN and were not detected again on that cabled receiver array or on any other upstream or downstream arrays, indicating these fish migrated upstream and remained within the reservoir upon encountering one of these dams (Table 3.8). These seven fish were included in the forebay survival estimates, but were excluded from the forebay residence, route-specific survival, and dam passage survival calculations because it could not be confirmed that they passed the dam. 
Table 3.7. Distance of travel and median forebay residence time for steelhead kelts implanted with acoustic transmitters at Lower Granite, Little Goose, and Lower Monumental dams in 2013.

\begin{tabular}{|c|c|c|c|}
\hline Dam & $n$ & $\begin{array}{c}\text { Distance } \\
(\mathrm{km})\end{array}$ & $\begin{array}{c}\text { Forebay Residence } \\
\text { Time (Hours) } \\
\text { Median (Range) } \\
\end{array}$ \\
\hline Lower Granite & 144 & 1 & $1.87(0.26-59.91)$ \\
\hline Little Goose & 365 & 1 & $1.92(0.26-50.25)$ \\
\hline Lower Monumental & 294 & 1 & $1.35(0.13-89.47)$ \\
\hline
\end{tabular}
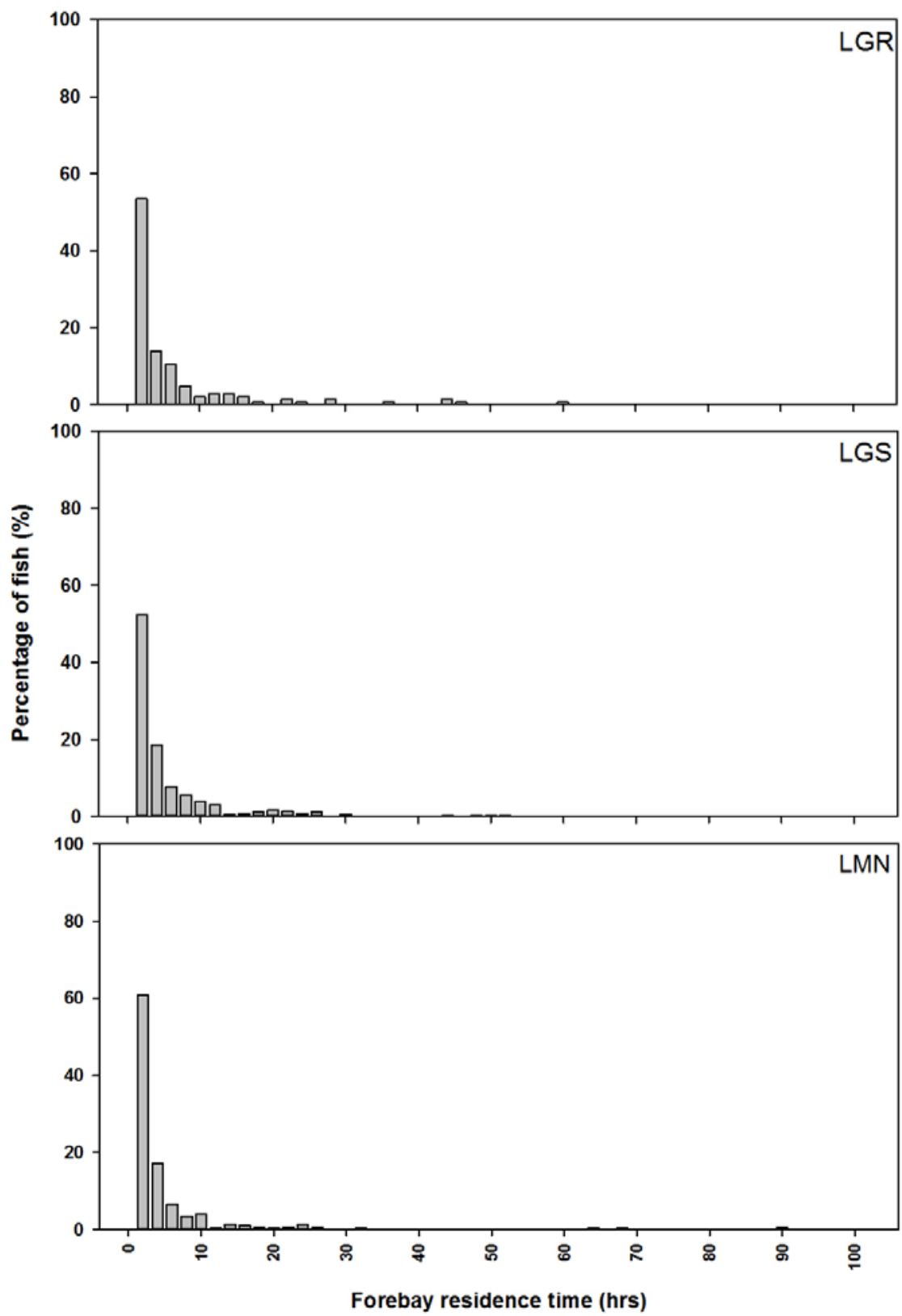

Figure 3.3. Frequency distribution of forebay residence times (hours) for steelhead kelts that passed Lower Granite (LGR), Little Goose (LGS), and Lower Monumental (LMN) dams in 2013. 
Table 3.8. Number of kelts last detected on the forebay array after detection on the dam-face cabled array (i.e., moving upstream) at Lower Granite, Little Goose, and Lower Monumental dams.

\begin{tabular}{lccc}
\hline Dam & $\begin{array}{c}\text { Number of Kelts } \\
\text { Detected on } \\
\text { Cabled Array }\end{array}$ & \multicolumn{2}{c}{$\begin{array}{c}\text { Kelts Last Detected } \\
\text { Moving Upstream } \\
\text { from Dam Face }\end{array}$} \\
\cline { 3 - 4 } Lower Granite & 144 & 0 & $\%$ \\
Little Goose & 375 & 3 & 0.0 \\
Lower Monumental & 298 & 4 & 0.8 \\
\hline
\end{tabular}

\subsubsection{Tailrace Egress}

The distance between the cabled receiver arrays and tailrace arrays ranged from 1 to $2 \mathrm{~km}$ for each FCRPS dam monitored (Table 3.9). Median tailrace egress times ranged from 0.37 hours (at LMN) to 0.60 hours (at LGR). The shortest recorded tailrace egress time was 0.18 hours (at LGS), and the longest was 99.19 hours (at LGR). Over 85\% of the kelts that moved through the tailraces of LGR, LGS, and LMN did so within 2 hours (Figure 3.4).

Table 3.9. Distance of travel and median tailrace egress time (hours) for steelhead kelts implanted with acoustic transmitters at Lower Granite, Little Goose, and Lower Monumental dams in 2013.

\begin{tabular}{lccc}
\hline & & & $\begin{array}{c}\text { Tailrace Egress Time } \\
\text { (Hours) }\end{array}$ \\
\cline { 3 - 4 } \multicolumn{1}{c}{ Dam } & $n$ & Distance $(\mathrm{km})$ & Median (Range) \\
\hline Lower Granite & 135 & 2 & $0.60(0.22-99.19)$ \\
Little Goose & 359 & 1 & $0.52(0.18-57.59)$ \\
Lower Monumental & 289 & 2 & $0.37(0.19-46.79)$ \\
\hline
\end{tabular}

\subsubsection{Project Passage Times}

The distance between the forebay and tailrace arrays ranged from 2 to $3 \mathrm{~km}$ for each FCRPS dam investigated in this study (Table 3.10). Median project passage times ranged from 2.00 hours (at LMN) to 3.06 hours (at LGR). The shortest recorded project passage time was 0.36 hour (at LMN) and the longest was 103.42 hours (at LGR). Project passage times for more than $80 \%$ of all kelts that passed LGR, LGS, or LMN was less than 12 hours (Figure 3.5).

Table 3.10. Distance of travel and median project passage time (hours) for steelhead kelts implanted with acoustic transmitters at Lower Granite, Little Goose, and Lower Monumental dams in 2013.

\begin{tabular}{lccc}
\hline & & & $\begin{array}{c}\text { Project Passage Time } \\
\text { (Hours) }\end{array}$ \\
\cline { 3 - 4 } \multicolumn{1}{c}{ Dam } & $n$ & Distance $(\mathrm{km})$ & Median (Range) \\
\hline Lower Granite & 135 & 3 & $3.06(0.77-103.42)$ \\
Little Goose & 359 & 2 & $2.78(0.49-58.30)$ \\
Lower Monumental & 289 & 3 & $2.00(0.36-93.72)$ \\
\hline
\end{tabular}




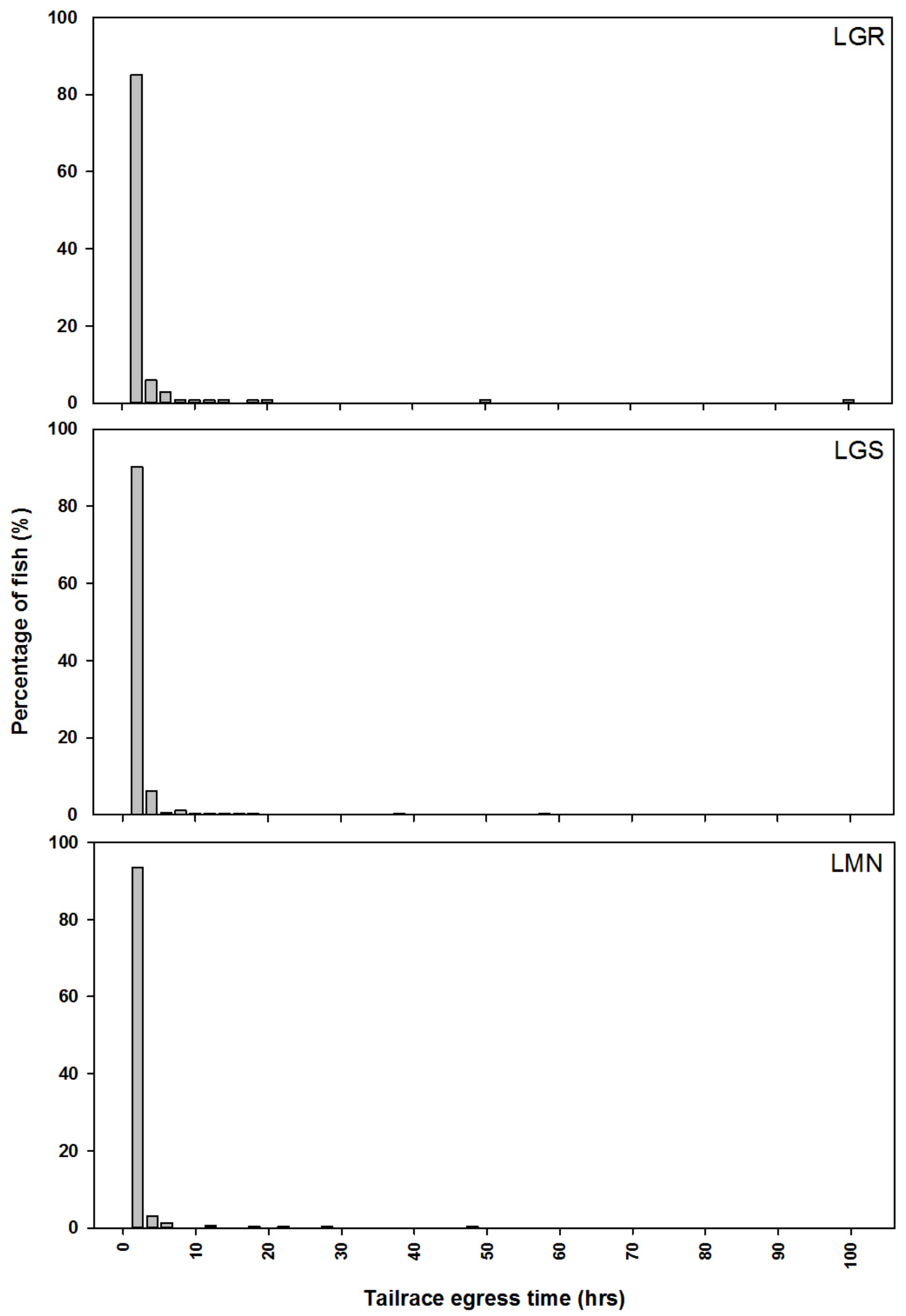

Figure 3.4. Frequency distribution of tailrace egress times (hours) for steelhead kelts that passed Lower Granite (LGR), Little Goose (LGS), and Lower Monumental (LMN) dams in 2013. 


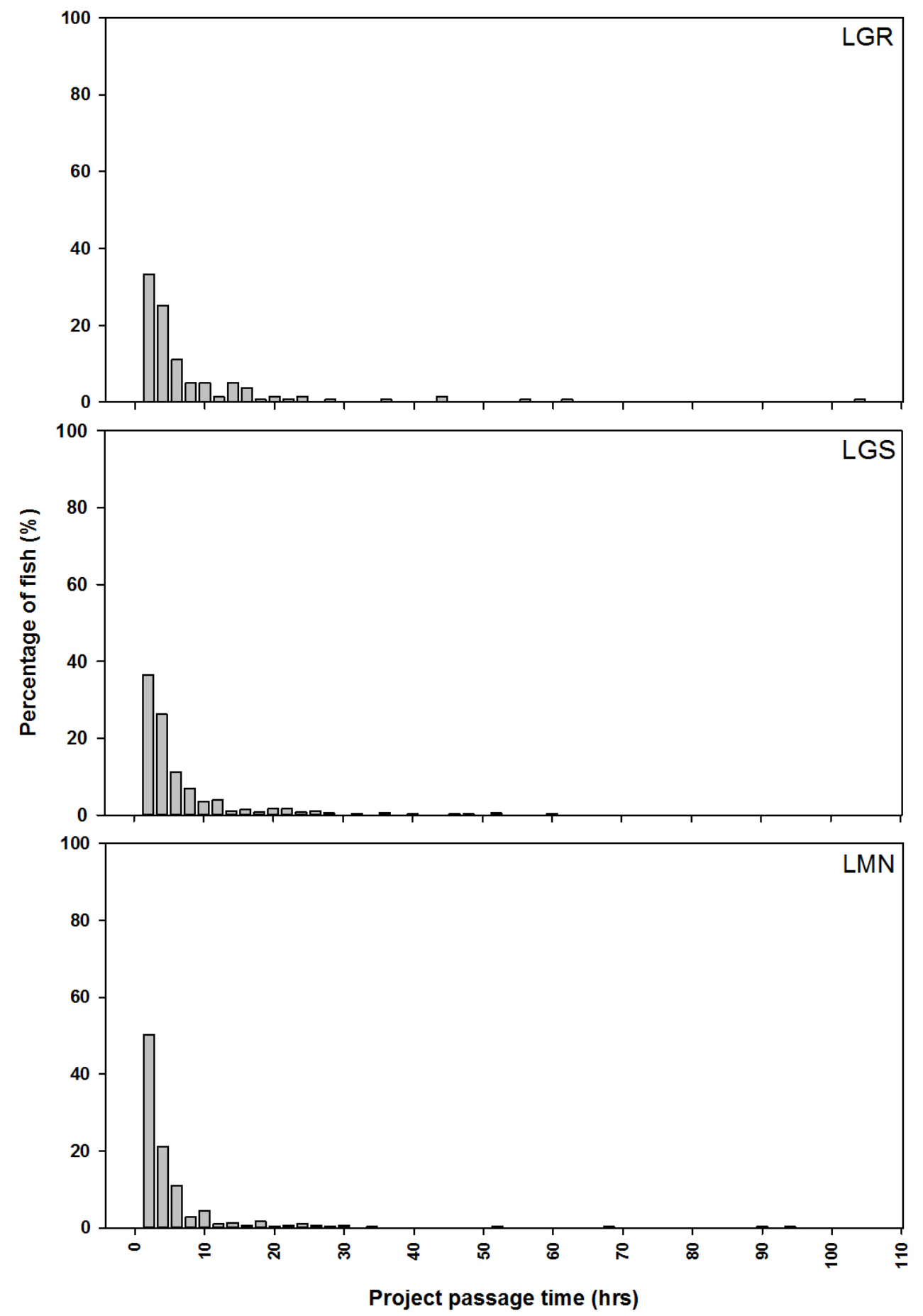

Figure 3.5. Frequency distribution of project passage times (hours) for steelhead kelts that passed Lower Granite (LGR), Little Goose (LGS), and Lower Monumental (LMN) dams in 2013.

\subsubsection{Travel Rates}

Travel rates were calculated from release to first downstream array and for river reaches located between detection locations. Of the kelts captured and tagged in the tributaries, those released in Fish 
Creek had the highest median travel rate $(88.2 \mathrm{~km} /$ day) from release to rkm 743 . Kelts captured and tagged in Joseph Creek and the East Fork Potlatch River had similar median travel rates of $16.7 \mathrm{~km} /$ day and $16.6 \mathrm{~km} /$ day, respectively. Kelts released in Asotin Creek had the slowest median travel rate (10.5 $\mathrm{km} /$ day) of all tributary groups. Once kelts reached rkm 743, travel rates generally increased as fish migrated downstream; the lowest median travel rates occurred in the Snake River $(20.0 \mathrm{~km} /$ day from rkm 743 to 696; Figure 3.6) and the highest median travel rates occurred in the Columbia River (129.1 km/day from rkm 126 to rkm 113). Median travel rates were generally highest in the tailrace of each dam and lowest in the forebay of the dams (46.2 to $130.0 \mathrm{~km} /$ day).

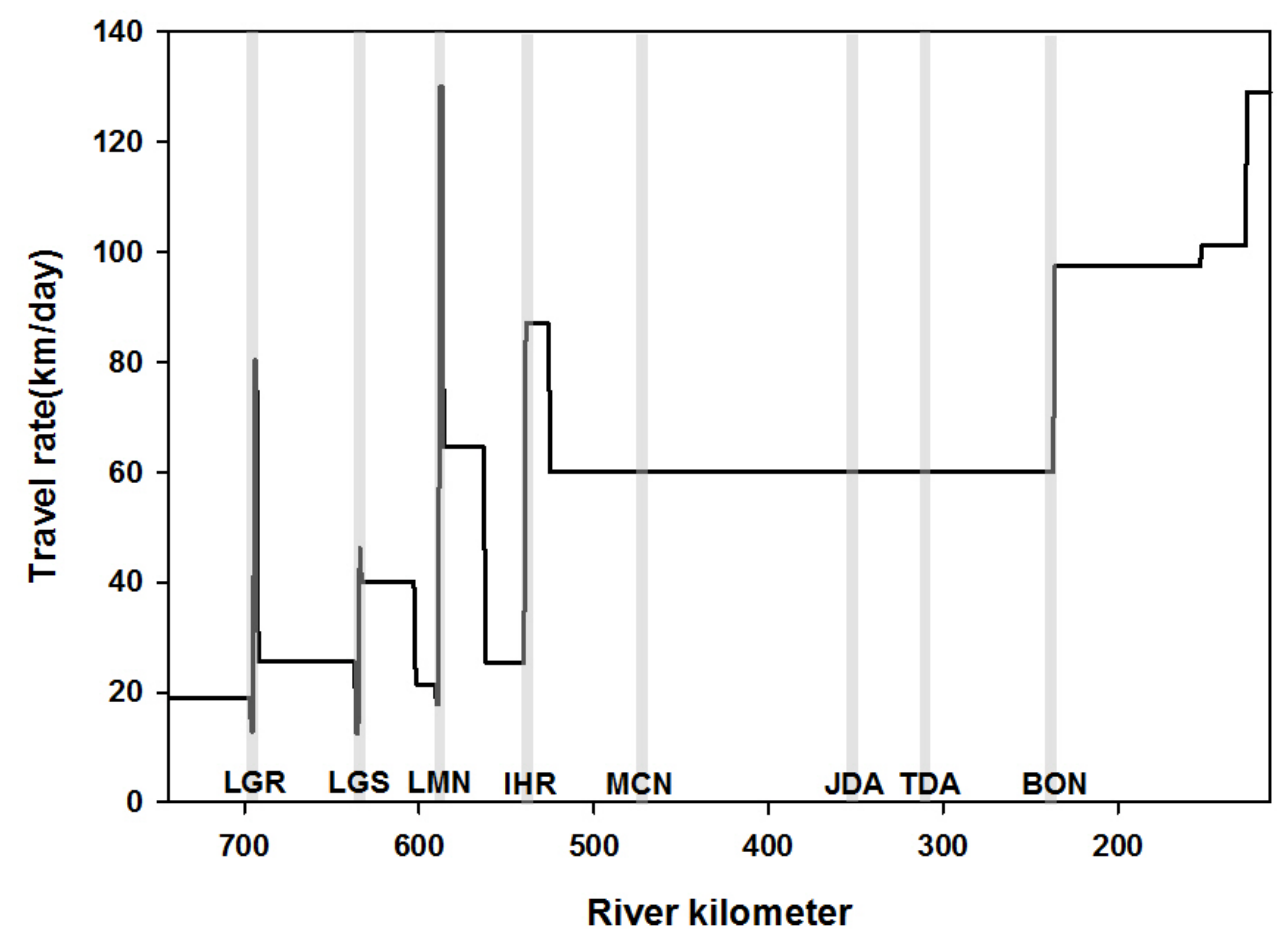

Figure 3.6. Median travel rates ( $\mathrm{km} /$ day) of steelhead kelts through various reaches of the Snake and Columbia rivers from rkm 743 to 113 in 2013.

\subsection{Estimation of Population Abundance Arriving at Lower Granite Dam}

A total of 954 steelhead kelts were sampled at the LGR JFF separator. By dividing this number by the proportion of acoustic-tagged kelts that passed LGR through the JBS (0.0486), we estimated that 19,630 steelhead kelts passed LGR in 2013. Calculating the population abundance separately for adiposeclipped and unclipped kelts produced an estimated 7,819 clipped and 11,811 unclipped kelts that passed LGR in 2013.

Using the Lincoln-Petersen method, we estimated that 14,022 (SE = 4,567) unclipped kelts were present in the tributaries at the time of tagging. Multiplying this estimate by the estimated survival from release to LGR for all kelts tagged in tributaries $(S=0.838)$ resulted in an estimate of 11,750 unclipped kelts that passed LGR. Agreement between the estimates of unclipped kelts using the JBS passage 
proportion and the Lincoln-Petersen methods indicates that we may be relatively confident in our kelt population abundance estimate.

\subsection{Iteroparity Rates}

PTAGIS (www.ptagis.org) was queried for the detection histories of all kelts included in this study, as well as those included in the 2012 study. These detection histories were examined to determine the migration behavior of kelts prior to their inclusion in this study and to determine if any kelts made upstream movements after their inclusion in this study. No kelts included in this study had PIT-tag detection histories consistent with spawning events in prior years. At the time of this report (31 March 2014), no kelts that were tagged in 2013 had been detected moving back upstream in the FCRPS. Return rates of steelhead kelts at the time of this revision (15 December 2014) tagged in this study can be found in Appendix K of this document.

Four of the 324 (1.2\%) kelts that were tagged with acoustic transmitters in 2012 were detected making upstream migrations in the summer and fall of 2013. One of the returning fish, a female, was tagged in 2012 at the Joseph Creek weir, and the remaining three were tagged at LGR. The kelt tagged at Joseph Creek was detected in August 2013 at the PIT-tag detection array near the mouth of the Deschutes River (at rkm 328). The Deschutes River is a tributary of the Columbia River and Snake River steelhead commonly use it as a thermal refuge during summer months because it generally has cooler water temperatures than the Columbia River (High et al. 2006). This kelt was later detected in November 2013 as it passed LGR. The other three fish (two females and one male) were detected moving upstream through the FCRPS and in the LGR adult fish ladder in August (female) and September (male and female) 2013. The female detected in the LGR adult fish ladder in September was detected in Joseph Creek in March 2014.

\subsection{JSATS Performance}

JSATS performance was evaluated in terms of detection probabilities of autonomous and cabled receiver arrays, fish distribution at autonomous arrays, and tag failure.

\subsubsection{Detection Probabilities at Cabled and Autonomous Arrays}

Detection probabilities of all cabled and autonomous receiver arrays used for survival estimation exceeded 0.99 for the 2013 season (Table G.1 and Table G.2).

\subsubsection{Multiple Detections on Autonomous Arrays}

Tagged kelts were generally detected on two or more autonomous receivers within an array during their seaward migrations (Table G.3). The median percentage of fish detected on two or more receivers within an autonomous array was $97.8 \%$ (range: 69.2\%-100.0\%). 


\subsubsection{Tag Life}

In total, 20 tags from the 2012 tag lot and 25 tags from the 2013 tag lot were used to estimate tag life. Of the 2012 tags, 4 of 20 (20.0\%) tags died within 24 hours of their activation. Due to the high initial tag failure, only 13 tags from the 2012 tag lot were used in the field portion of the 2013 study, which was an insufficient sample size to adjust for tag failure of survival estimates. Therefore, fish implanted with 2012 transmitters were not included in the survival estimation. However, these fish were used to estimate travel time and passage proportions. In comparison, all 25 of the 2013 tags lasted at least 60 days.

During 2013, all of the kelts tagged with acoustic transmitters passed the final survival detection array at Martin Bluff (rkm 126) in 30.8 days or fewer (Figure G.1). Therefore, there was no need to apply a taglife correction to survival probability estimates.

\subsection{Dam-Passage Characteristics}

The proportions of kelts and the proportion of flow that flowed through each route in each dam, along with the diel distribution of fish passage through the dams are reported below.

\subsubsection{Dam Passage versus Flow}

During the time of tagged kelt passage at each dam (see Appendix $\mathrm{H}$ for dates for each dam), the largest percentage of flow passed through the powerhouses at LGR, LGS, and LMN $(69.8 \%, 69.2 \%$, $62.4 \%$, respectively). However, the largest proportion of kelts passed through the spillways at all dams (Appendix H). Furthermore, the majority of kelts that passed LGR, LGS, and LMN (71.0\%-79.9\%) did so through the spillway weir, whereas less than $13 \%$ of the flow passed through this route at each dam.

\subsubsection{Diel Distribution}

The hourly distributions of kelt passage at LGR, LGS, and LMN were fairly consistent throughout the season in 2013 (Appendix I). At all dams studied in 2013, approximately 75\% of kelts passed through the dam during daylight hours, whereas $25 \%$ of kelts passed during hours of darkness based on their last detection on the cabled receiver arrays. 


\subsection{Discussion and Conclusions}

Discussion of steelhead kelt migration success, reach survival, passage proportions and route-specific survival, travel rates, population abundance, and associated conclusions are presented in the following sections.

\subsection{Migration Success}

The 2013 migration success rate of kelts (to rkm 126) was lower than the success rates observed in 2012 (to rkm 113; Colotelo et al. 2013) and 2004 (to rkm 232; Boggs and Peery 2004), but higher than the success rates observed in 2001 and 2002 (to rkm 181; Hatch et al. 2003, Wertheimer and Evans 2005; Table 4.1). River conditions may have been partially responsible for some of the observed differences in migration success between years. Related to the years of study considered here, Columbia River discharge was highest in 2012 (when the highest migration success rate was observed) and lowest in 2001 (when the lowest migration success rate was observed; Figure 4.1). In fact, discharge was so low in 2001 that no water was spilled at Snake River dams, forcing all kelts to pass via JBSs, turbine units, or navigation locks. The low flow conditions of 2001 and high flow conditions of 2012 are shown on a plot of Snake River discharges (Figure 4.2). River temperature may have also contributed to differences in migration success among study years: Columbia River water temperature was highest in 2001 and generally lower in 2012 (Figure 4.3).

The condition of kelts tagged in each study is also important to consider when comparing the results among years. For example, a higher percentage of good condition kelts $(90.1 \%)$ were implanted with transmitters in 2012 than in 2013 (75.4\%; Table 4.1). The location of the array to which migration success rate was measured may have also played a role in the observed differences among studies and years. However, survival of Snake River steelhead kelts appeared to be quite high in the Columbia River downstream from BON in both 2012 and 2013 (0.897 from rkm 235 to 156 in 2012 and 0.910 from rkm 236 to 126 in 2013). Therefore, the difference in array location likely had a relatively small effect on differences in migration success among studies and years.

\subsection{Reach Survival}

Reach survival, estimated on a per-kilometer basis (Figure 3.3) to allow for comparison among reaches of different lengths, was lowest in the immediate forebays of Snake River dams in 2013. This trend is mostly consistent with observations from the 2012 study (Figure 4.4; Colotelo et al. 2013). However, in 2012, the lowest survival per kilometer estimate occurred in the LGR forebay; whereas in 2013, the lowest survival per kilometer estimate occurred in the LGS forebay. In both 2012 and 2013, survival was generally lower through reaches that included a dam as compared to river reaches between dams (excluding the immediate forebay). Of the reaches evaluated in 2013 that contained a dam, survival per kilometer was lowest from LGR to the LGS forebay. In 2012, survival per kilometer estimates were similar among the reaches that contained LGR, LGS, and LMN (Colotelo et al. 2013).

When all kelts (from all capture and tagging locations) were combined, survival was higher in 2012 than in 2013 in all reaches that were monitored in both years. Again, it is possible that differences in river 
conditions (e.g., discharge and water temperature) between years accounted for the observed differences in survival with the higher discharge and cooler water conditions of 2012 contributing to higher survival.

A higher percentage of kelts tagged in the tributaries were in fair condition in 2013 (25\%) compared to $2012(0 \%)$. It is possible that the higher proportion of fair condition kelts tagged in 2013 contributed to the lower survival estimates we observed. In general, fair condition kelts had lower survival than good condition kelts (Figure 4.5). In particular, the higher proportion of fair condition kelts implanted in the tributaries in 2013 likely contributed to the low survival we observed between the LGR forebay and the LGS forebay. Fair condition kelts had a survival probability of 0.345 in this reach compared to 0.745 for good condition kelts. In 2012, only good condition kelts were implanted in the tributaries and had a 0.882 probability of survival between the LGR forebay and the LGS forebay. Therefore, river conditions may have also contributed to the lower survival observed in this reach in 2013.

The location at which kelts were captured may have influenced survival estimates. Only good and fair condition kelts were implanted with a transmitter in the tributaries and at the LGR JFF. However, kelts tagged in good or fair condition in the tributaries may have degraded to a poorer condition by the time they arrived at the LGR forebay. Therefore, estimates of survival between the LGR forebay and the LGS forebay, which consisted entirely of kelts tagged in the tributaries, may have been biased low, relative to the other dams. This hypothesis is supported by the lower survival we observed for both good and fair condition kelts implanted in the tributaries compared to those implanted at LGR through reaches the groups shared in common (from rkm 636 to rkm 236; Figure 4.5). Overall, survival of kelts tagged in the tributaries was about 5\% lower than observed for LGR JFF-tagged kelts in most Snake River reaches located between the LGS forebay and the IHR forebay.

Kelts tagged in the tributaries survived at a similar rate in the Columbia River ( $S=0.732$ from rkm 525 to $\mathrm{rkm} 236$ ) to those tagged at the $\operatorname{LGR~JFF~}(S=0.651$; likelihood ratio test, $P=0.32$ ). Overall cumulative survival estimates (from rkm 636 to rkm 236) were fairly similar between the two groups in 2013. These results are in contrast to those observed in 2012 when LGR JFF kelts survived at a much higher rate than tributary kelts in both the Snake and Columbia rivers, resulting in a $24 \%$ difference in cumulative survival between the two groups from the LGS forebay (rkm 636) to the BON forebay (rkm 236; Colotelo et al. 2013).

In 2012, kelts captured and tagged at the tributary sites located farthest upstream, specifically Fish Creek (rkm 944) and the Crooked River (rkm 961), had the lowest migration success rates of all tagged groups (Colotelo et al. 2013). These results indicated that perhaps kelt survival was negatively correlated with the distance of spawning sites from the ocean. Although kelts captured and tagged in Fish Creek in 2013 had the lowest survival rate from release to rkm 236 of all tributary groups, we did not observe this same trend among the other tributary sites. In fact, kelts captured and tagged in Asotin Creek (rkm 760), which is the tributary site located nearest to LGR, had the second-lowest survival rate from release to the BON forebay (rkm 236). As suggested by Colotelo et al. (2013), differences in migration timing among tributary groups may also affect survival, making it difficult to identify whether distance traveled, migration timing, or some other factor has the greatest effect on the survival rates of tributary groups. 
Table 4.1. Summary of studies examining the downstream migration success of steelhead kelts in the Federal Columbia River Power System.

\begin{tabular}{|c|c|c|c|c|c|c|c|c|c|}
\hline \multirow[b]{2}{*}{ Study } & \multirow[b]{2}{*}{ Year } & \multirow{2}{*}{\multicolumn{2}{|c|}{$\begin{array}{c}\text { Migration } \\
\text { Success Rate } \\
(\%)^{(b)}\end{array}$}} & \multirow[b]{2}{*}{ Fish Release Site } & \multirow[b]{2}{*}{$\begin{array}{c}\text { Downstream } \\
\text { Array }\end{array}$} & \multirow[b]{2}{*}{$n$ Tagged } & \multicolumn{3}{|c|}{ Fish Condition } \\
\hline & & & & & & & Good (\%) & Fair (\%) & Poor (\%) \\
\hline Wertheimer and Evans 2005 & 2001 & Radio & 4.1 & LGR Tailrace & rkm 181 & 197 & $73.0^{(c)}$ & $27.0^{(c)}$ & $\mathrm{n} / \mathrm{a}$ \\
\hline Wertheimer and Evans 2005 & 2002 & Radio & 15.4 & LGR Tailrace & rkm 181 & 167 & $73.0^{\text {(c) }}$ & $27.0^{(\mathrm{c})}$ & $\mathrm{n} / \mathrm{a}$ \\
\hline Hatch et al. 2003 & 2002 & Radio & 13.3 & LGR Tailrace & BON Tailrace & 210 & 51.4 & 27.6 & 21.0 \\
\hline Boggs and Peery 2004 & 2003 & Radio & 34.4 & LGR Tailrace & rkm 232 & 212 & 66.5 & 33.5 & $\mathrm{n} / \mathrm{a}$ \\
\hline Colotelo et al. 2013 & 2012 & JSATS & 37.0 & $\begin{array}{l}\text { Tributaries and } \\
\text { LGR Tailrace }\end{array}$ & rkm 113 & 324 & 89.8 & 10.2 & $\mathrm{n} / \mathrm{a}$ \\
\hline Current Study & 2013 & JSATS & 27.3 & $\begin{array}{l}\text { Tributaries and } \\
\text { LGR Tailrace }\end{array}$ & rkm 126 & 487 & 75.4 & 24.6 & $\mathrm{n} / \mathrm{a}$ \\
\hline
\end{tabular}

(a) Radio transmitters were attached externally. JSATS transmitters were implanted internally.

(b) Migration success is defined as the percentage of tagged fish detected at an array downstream of all Federal Columbia River Power System dams.

(c) Wertheimer and Evans (2005) did not report the proportion of kelts in good and fair condition for the individual years of tagging, but reported that overall 73.0\% of fish were in good condition. 


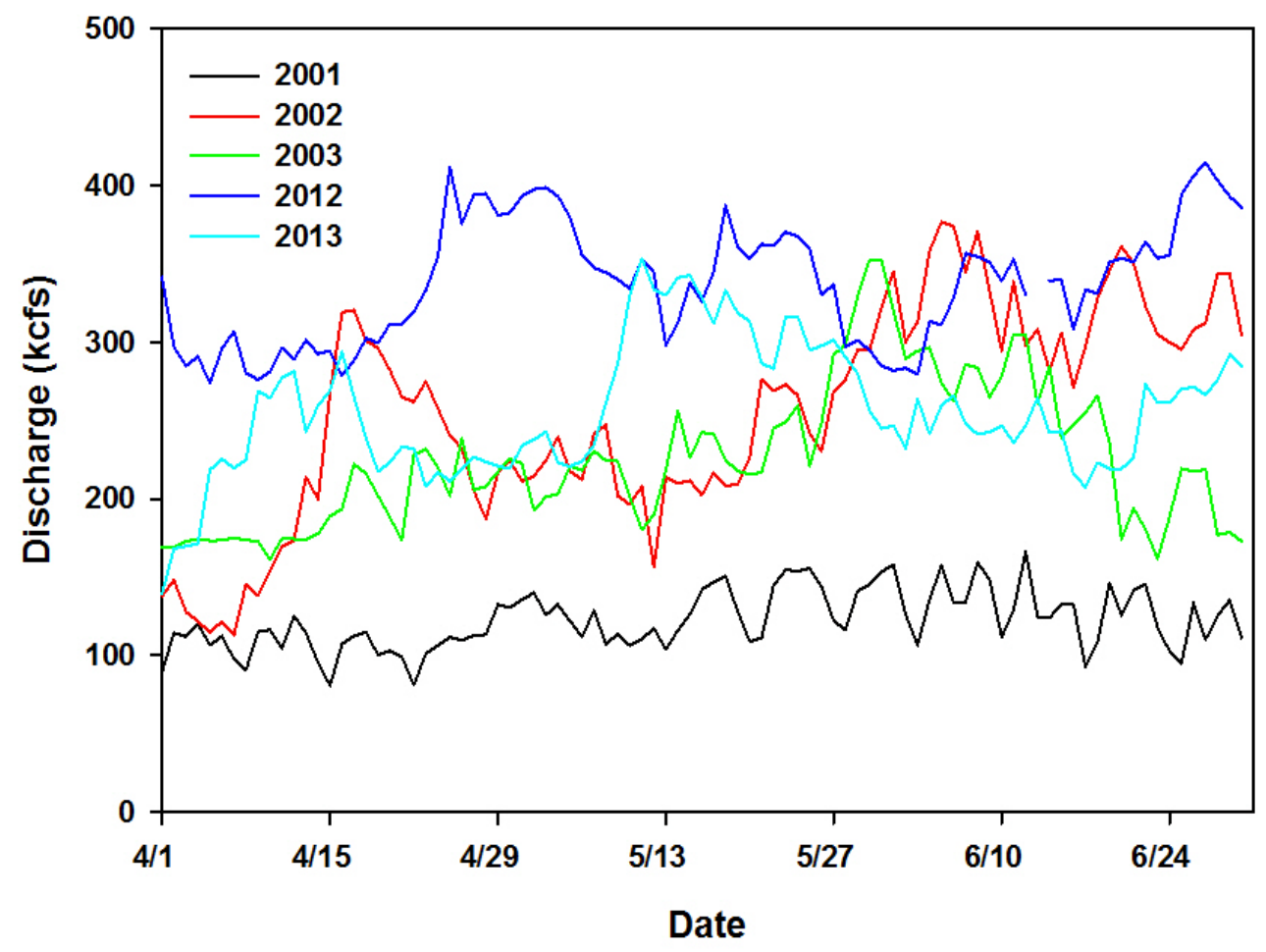

Figure 4.1. Total daily discharge (kcfs) from McNary Dam in years that steelhead kelt telemetry studies occurred in the Federal Columbia River Power System.

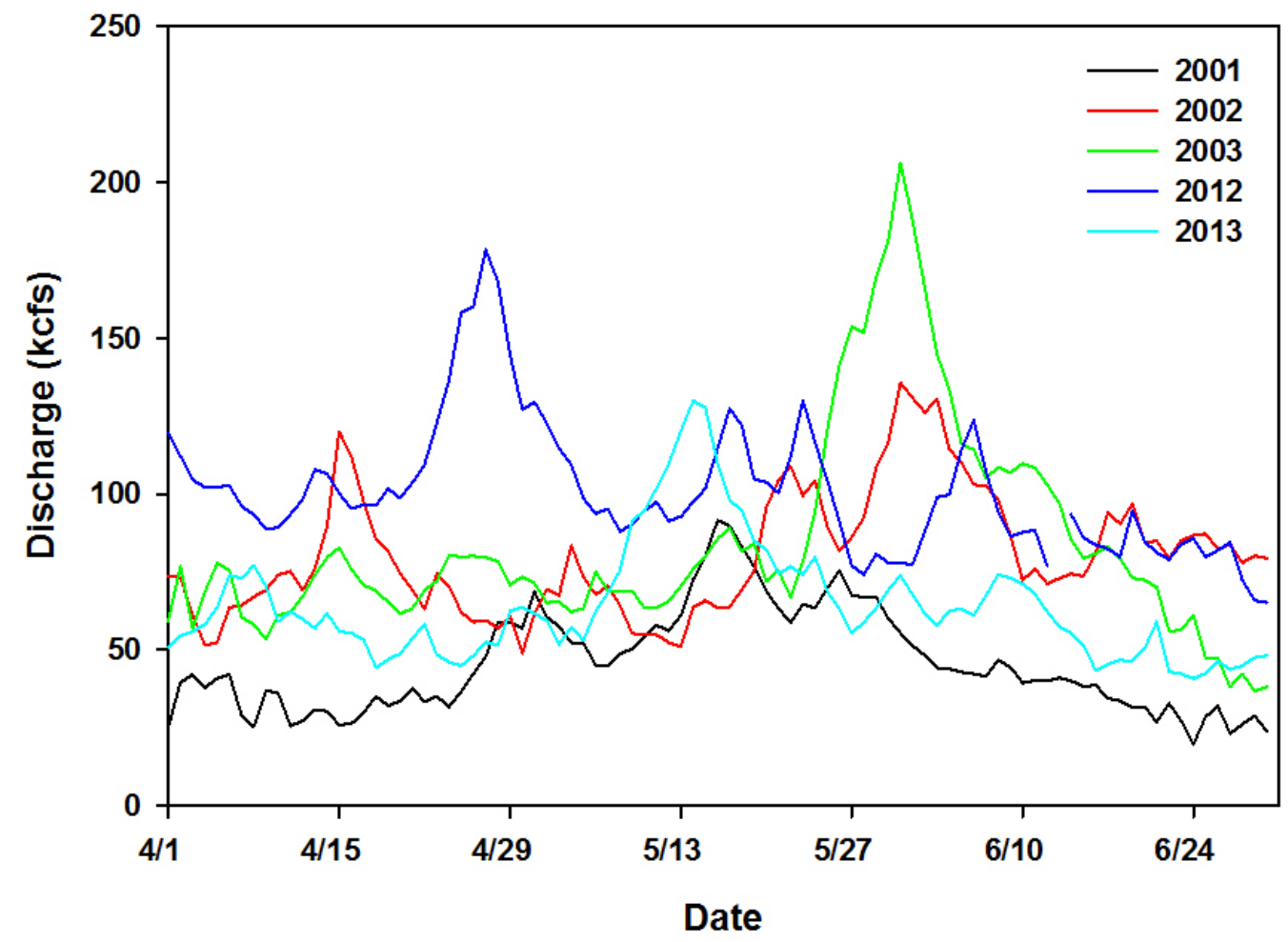

Figure 4.2. Total daily discharge (kcfs) from Lower Granite Dam in years that steelhead kelt telemetry studies occurred in the Federal Columbia River Power System. 


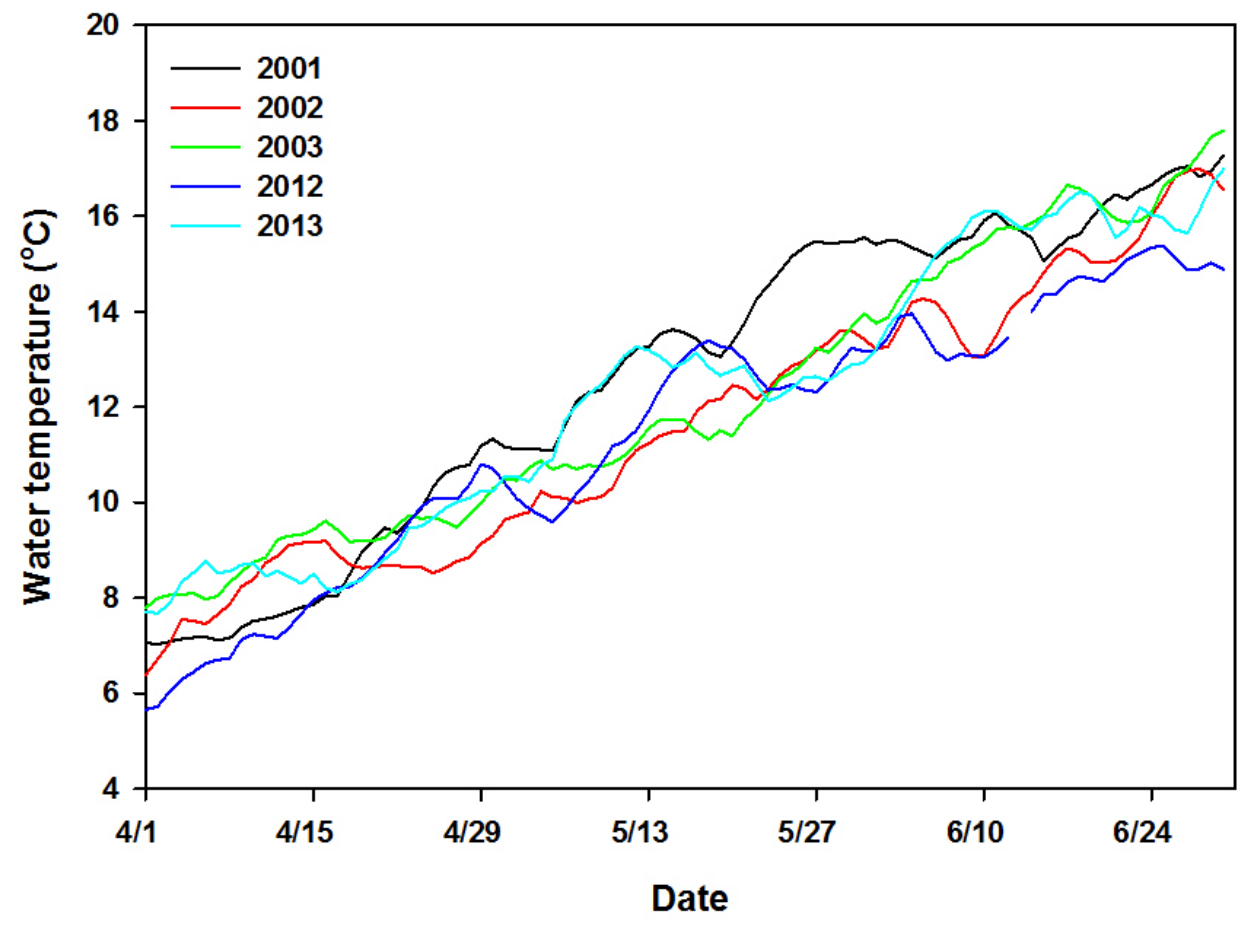

Figure 4.3. Daily temperatures $\left({ }^{\circ} \mathrm{C}\right)$ recorded at McNary Dam in years that steelhead kelt telemetry studies occurred in the Federal Columbia River Power System.

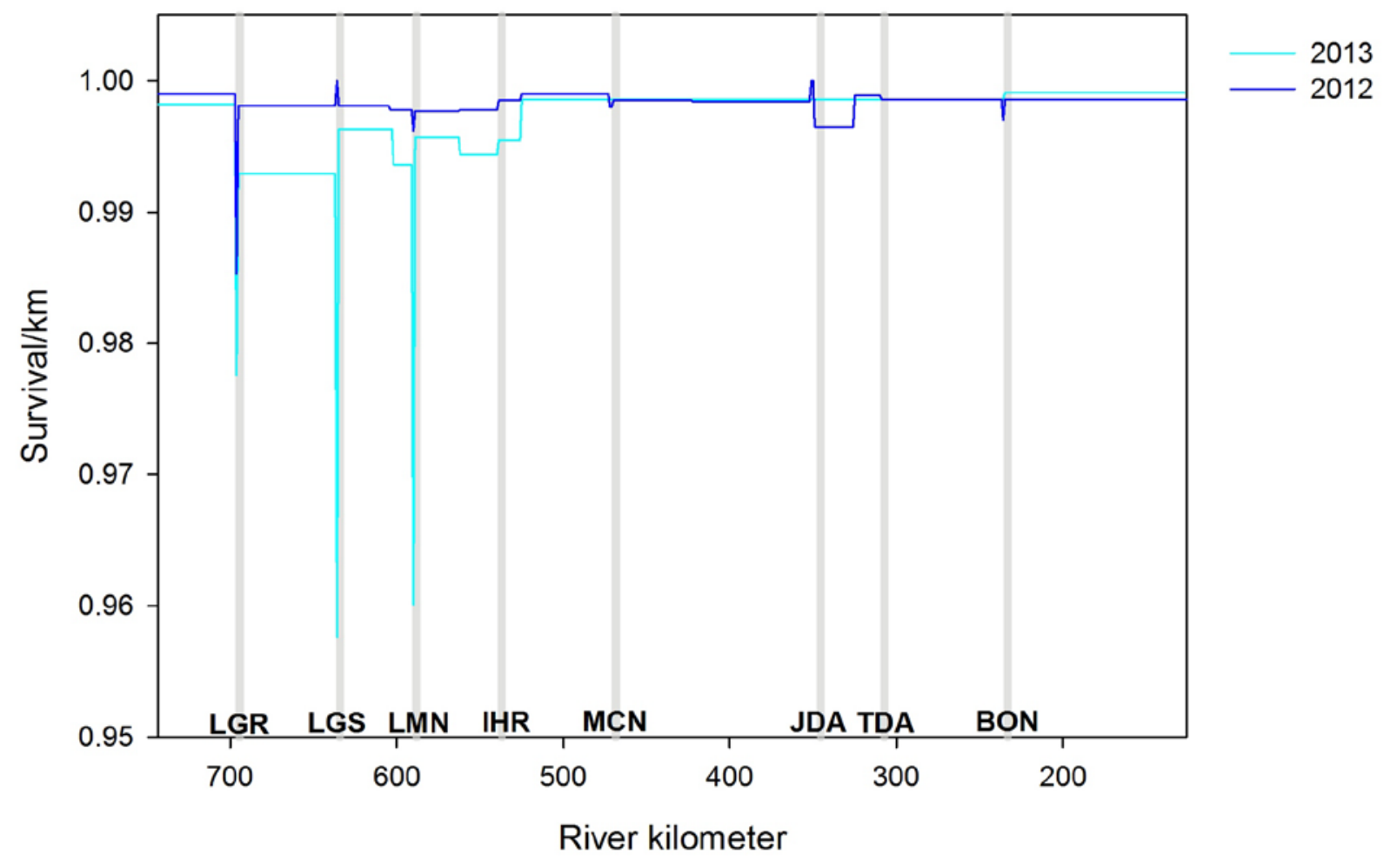

Figure 4.4. Standardized reach survival probability estimates for all tagged steelhead kelts detected in the Federal Columbia River Power System in 2012 (dark blue) and 2013 (light blue). 

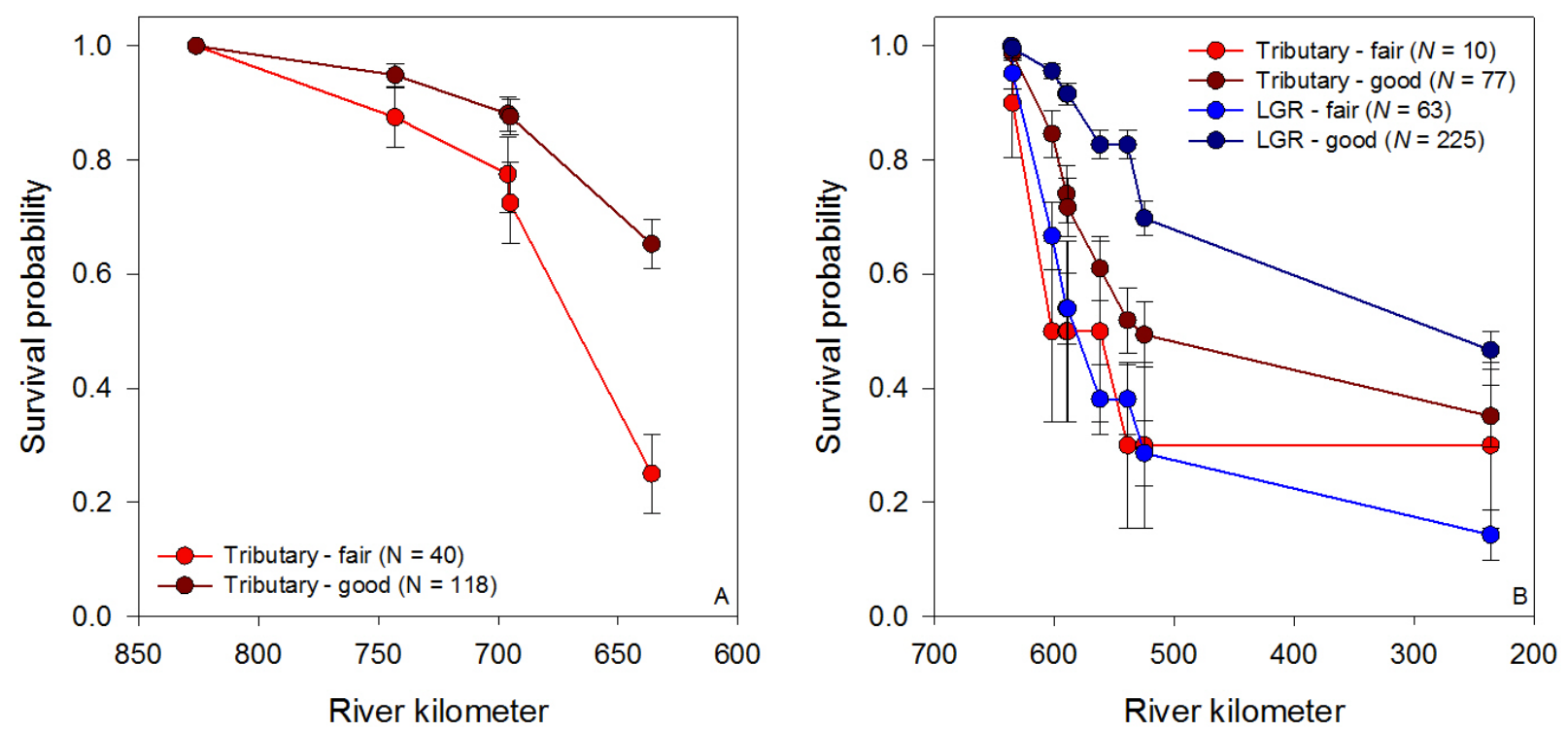

Figure 4.5. (A) Cumulative survival estimates from release to the forebay of Little Goose Dam (rkm 636) for good (dark red) and fair (red) condition kelts tagged in the tributaries of the Snake and Clearwater rivers in 2013. Kelts were tagged and released in multiple tributaries. The arithmetic mean of the tributary weir releases (rkm 826) was used to represent the starting point for all kelts tagged in the tributaries. (B) Cumulative survival estimates from the forebay of Little Goose Dam (rkm 636) to the forebay of Bonneville Dam (rkm 236) for good and fair condition kelts tagged in the tributaries (dark red and red) and at the Lower Granite Dam Juvenile Fish Facility (LGR; dark blue and blue) in 2013.

\subsection{Passage Proportions and Route-Specific Survival}

Spillway routes (spillway weirs and traditional spillways) were the most commonly used route of kelt passage at LGR, LGS, and LMN in 2013, which is similar to the results obtained during previous studies of kelt passage at Snake and Columbia river dams (Wertheimer and Evans 2005; Wertheimer 2007; Colotelo et al. 2013; Table 4.2). The percentage of kelts that used the weirs was even higher in 2013, particularly at LGR where the percentage increased from 57\% in 2012 to $80 \%$ in 2013 . A 10\% increase was observed from 2012 to 2013 at LGS where spillway weir use was 61\% in 2012 and 71\% in 2013. Spillway weir use was similar at LMN in 2012 (68\%) and 2013 (71\%). The next most-commonly used route of kelt passage at all three dams was through traditional spill routes, which is consistent with 2012 results (Table 4.2). However, the percentage of kelts that passed through traditional spill routes decreased from 2012 levels at all three dams: from 26\% to 13\% at LGR, 25\% to $16 \%$ at LGS, and 21\% to 16\% at LMN. Similar to previous studies, a relatively small percentage of kelts passed through the powerhouse at the dams (Wertheimer and Evans 2005; Wertheimer 2007; Colotelo et al. 2013). The percentage of kelts that passed through the turbines decreased at LGR from 7\% in 2012 to 1\% in 2013. One reason for this may have been the prototype overflow weir that was tested in unit 5 in 2013. Of the four kelts that entered unit 5, three (75\%) were guided into the JBS. In comparison, none of the kelts $(n=2)$ that entered unit 5 in 2012 were guided into the JBS. The percentage of kelts that passed through the turbines remained similar at LGS (5\% in both 2012 and 2013) and increased at LMN from 5\% in 2012 to 7\% in 2013 (Table 4.2). The percentage that passed through the JBS was lower in 2013 than we observed in 
2012 at all three dams. Similar to 2012, LGS had the highest percentage of JBS passage of the three dams and LGR again had the lowest.

The amount of discharge through each route may have affected the dam passage distribution of kelts at the Snake River dams in 2012 and 2013. The percentage of discharge passed by the spillway weirs during the study period was higher in 2013 at all three dams than it was in 2012. As mentioned previously, a greater percentage of kelts passed all three dams via the spillway weirs in 2013 than in 2012. A similar trend was observed for traditional spill routes at LGR and LGS: a higher percentage of discharge through traditional spill routes correlated with a higher percentage of kelts passing through those routes in 2012 than in 2013. The opposite trend was observed in both years for powerhouse passage at all three dams: a larger percentage of kelts passed through the powerhouse when the percentage of discharge that passed through the powerhouse was lower.

Dam passage survival, which included a rather lengthy river reach downstream of each dam (27 to $59 \mathrm{~km})$, differed by route of passage. At LGR, too few kelts $(n=9)$ passed through the powerhouse to provide a reasonable evaluation of survival for turbine- or JBS-passed fish. However, survival probabilities for kelts that passed the spillway were low through both traditional spill (0.71) and spillway weir (0.67) routes in 2013. These results are in sharp contrast to those obtained in 2012 when the probability of survival was 0.91 and 0.90 through LGR traditional spill and spillway weir routes, respectively. It is possible that the higher percentage of fair condition fish tagged in the tributaries in 2013 contributed to the lower dam passage survival observed at LGR in 2013. An evaluation of routespecific survival by condition revealed that the high proportion of fair condition fish introduced a relatively small bias on route-specific survival estimates at LGR. Although fair condition fish had substantially lower survival through all routes, survival of good condition kelts was still considerably lower through traditional spill (0.77) and spillway weir (0.76) routes in 2013 compared to 2012 (Table 4.3). These estimates are also relatively low compared to those observed at LGS and LMN, where dam passage survival was highest in 2012 and 2013 for kelts that passed via the spillway weir or the JBS. However, survival through all routes (except the turbines) was lower at both dams in 2013 than it was in 2012. The difference in turbine survival may be more apparent than real, due to the small sample size of turbine-passed fish at both dams in both years. 
Table 4.2. The percentage and route-specific survival ( \pm SE) estimates of tagged kelts that passed through Lower Granite (LGR), Little Goose (LGS), and Lower Monumental (LMN) dams during the 2012 and 2013 seasons. Single-release survival estimates were based on pooled data for each major route of passage (i.e., traditional spill, spillway weir, turbine, juvenile bypass system [JBS]) at each dam.

\begin{tabular}{|c|c|c|c|c|c|c|c|c|c|c|c|c|c|}
\hline \multirow[b]{2}{*}{ Dam } & \multirow[b]{2}{*}{ Measure } & \multicolumn{6}{|c|}{2012} & \multicolumn{6}{|c|}{2013} \\
\hline & & $\mathrm{n}$ & $\begin{array}{c}\text { Traditional } \\
\text { Spill }\end{array}$ & $\begin{array}{l}\text { Spillway } \\
\text { Weir }\end{array}$ & Turbine & JBS & Unknown & $\mathrm{n}$ & $\begin{array}{c}\text { Traditional } \\
\text { Spill }\end{array}$ & $\begin{array}{c}\text { Spillway } \\
\text { Weir }\end{array}$ & Turbine & JBS & Unknown \\
\hline \multirow[b]{2}{*}{ LGR } & $\begin{array}{l}\text { Passage } \\
\text { percentage }\end{array}$ & 124 & $25.8 \%$ & $57.3 \%$ & $6.5 \%$ & $5.6 \%$ & $4.8 \%$ & 144 & $12.5 \%$ & $79.9 \%$ & $1.4 \%$ & $4.9 \%$ & $1.4 \%$ \\
\hline & $\begin{array}{l}\text { Survival } \\
\text { (SE) }\end{array}$ & & $\begin{array}{c}0.906 \\
(0.052)\end{array}$ & $\begin{array}{c}0.901 \\
(0.035)\end{array}$ & $\begin{array}{c}0.875 \\
(0.117)\end{array}$ & $\begin{array}{c}0.857 \\
(0.132)\end{array}$ & $\begin{array}{c}0.833 \\
(0.152)\end{array}$ & & $\begin{array}{c}0.706 \\
(0.111)\end{array}$ & $\begin{array}{c}0.667 \\
(0.046)\end{array}$ & $\begin{array}{c}0.750 \\
(0.217)\end{array}$ & $\begin{array}{c}0.250 \\
(0.217)\end{array}$ & $\begin{array}{c}0.000 \\
(0.000)\end{array}$ \\
\hline \multirow{2}{*}{ LGS } & $\begin{array}{l}\text { Passage } \\
\text { percentage }\end{array}$ & 288 & $24.7 \%$ & $60.8 \%$ & $4.5 \%$ & $10.1 \%$ & $0.0 \%$ & 359 & $15.9 \%$ & $71.0 \%$ & $5.3 \%$ & $6.7 \%$ & $1.1 \%$ \\
\hline & $\begin{array}{l}\text { Survival } \\
\text { (SE) }\end{array}$ & & $\begin{array}{c}0.943 \\
(0.028)\end{array}$ & $\begin{array}{c}0.967 \\
(0.014)\end{array}$ & $\begin{array}{c}0.779 \\
(0.119)\end{array}$ & $\begin{array}{c}0.966 \\
(0.034)\end{array}$ & - & & $\begin{array}{c}0.821 \\
(0.051)\end{array}$ & $\begin{array}{c}0.936 \\
(0.016)\end{array}$ & $\begin{array}{c}0.842 \\
(0.084)\end{array}$ & $\begin{array}{c}0.875 \\
(0.068)\end{array}$ & $\begin{array}{c}1.000 \\
(0.000)\end{array}$ \\
\hline \multirow{2}{*}{ LMN } & $\begin{array}{l}\text { Passage } \\
\text { percentage }\end{array}$ & 258 & $20.5 \%$ & $68.0 \%$ & $4.6 \%$ & $6.9 \%$ & $0.0 \%$ & 294 & $16.0 \%$ & $71.1 \%$ & $6.8 \%$ & $5.4 \%$ & $0.7 \%$ \\
\hline & $\begin{array}{l}\text { Survival } \\
\text { (SE) }\end{array}$ & & $\begin{array}{c}0.926 \\
(0.036)\end{array}$ & $\begin{array}{c}0.983 \\
(0.010)\end{array}$ & $\begin{array}{c}0.583 \\
(0.142)\end{array}$ & $\begin{array}{c}1.000 \\
(0.000)\end{array}$ & - & & $\begin{array}{c}0.826 \\
(0.056)\end{array}$ & $\begin{array}{c}0.927 \\
(0.018)\end{array}$ & $\begin{array}{c}0.842 \\
(0.084)\end{array}$ & $\begin{array}{c}0.938 \\
(0.061)\end{array}$ & $\begin{array}{c}0.500 \\
(0.354)\end{array}$ \\
\hline
\end{tabular}


Table 4.3. The percentage and route-specific survival ( \pm SE) estimates of fair and good condition kelts that passed through Lower Granite Dam (LGR) during the 2013 season. Single-release survival estimates were based on pooled data for each major route of passage (i.e., traditional spill, spillway weir) and powerhouse routes (i.e., turbine, juvenile bypass system) were combined due to low sample sizes.

\begin{tabular}{lllccc|cccc}
\hline & & \multicolumn{4}{c|}{ Fair } & \multicolumn{3}{c}{ Good } \\
\cline { 3 - 10 } Dam & Measure & $n$ & $\begin{array}{c}\text { Traditional } \\
\text { Spill }\end{array}$ & $\begin{array}{c}\text { Spillway } \\
\text { Weir }\end{array}$ & Powerhouse & $n$ & $\begin{array}{c}\text { Traditional } \\
\text { Spill }\end{array}$ & $\begin{array}{c}\text { Spillway } \\
\text { Weir }\end{array}$ & Powerhouse \\
\hline \multirow{2}{*}{ LGR } & $\begin{array}{l}\text { Passage } \\
\text { percentage }\end{array}$ & 29 & $13.8 \%$ & $75.9 \%$ & $10.3 \%$ & 101 & $12.9 \%$ & $82.2 \%$ & $5.0 \%$ \\
& $\begin{array}{l}\text { Survival } \\
\text { (SE) }\end{array}$ & & 0.500 & 0.318 & 0.333 & & 0.769 & 0.759 & 0.600 \\
& $(0.250)$ & $(0.099)$ & $(0.272)$ & & $(0.117)$ & $(0.047)$ & $(0.219)$ \\
\hline
\end{tabular}

\subsection{Travel Rates}

Travel rates of downstream-migrating salmonids can influence their migration and survival through a river system. This is particularly important in hydropower-influenced river systems because dams have been shown to reduce migration rates (Raymond 1969, 1979). Delays in migration can expose kelts to high water temperatures, increase the risk of predation, and deplete limited energy stores that are required for successful emigration to the ocean. This is particularly important for kelts, which have depleted energy stores because of recent spawning activity. Overall, the travel rates observed in this study follow similar trends to those reported from the 2012 FCRPS kelt passage study (Colotelo et al. 2013). The results from 2013 show a median travel rate of $48.3 \mathrm{~km}$ /day for tagged kelts that migrated from the LGR tailrace (rkm 693) to below BON (rkm 126). In 2012, tagged kelts migrated from the LGR tailrace (rkm 693) to the BON tailrace (rkm 233) at a median travel rate of $51.3 \mathrm{~km} /$ day (Colotelo et al. 2013). These travel rates are faster than those reported by Wertheimer and Evans (2005) from their 2001 and 2002 studies (19.0 and $27.3 \mathrm{~km} /$ day, respectively). The results of the 2012 (Colotelo et al. 2013) and 2013 studies support the idea presented by Wertheimer and Evans (2005) that river discharge is positively associated with the travel rates of kelts. In 2002 and 2012, the travel rates and mean river discharge were higher than in 2001 and 2013. Overall, the travel rates of kelts observed in 2012 and 2013 were both greater than those observed in 2001 and 2002 (Wertheimer and Evans 2005). However, the mean river discharge at LGR was not consistently higher in 2012 (101.5 kcfs) and 2013 (66.0 kcfs) compared to 2001 (47.3 kcfs) and 2002 (85.6 kcfs; Figure 4.2). In fact, travel rates observed in 2012 and 2013 were nearly double those from 2001 and 2002. These results suggest that other factors influence kelt migration rates. Dam configurations and operations have changed in the FCRPS in the years between 2002 and 2012 (e.g., installation of spillway weirs, court-ordered spill program), and these changes likely also contributed to the higher migration rates observed in recent years.

In 2013, we found similar ( $P$ > 0.05) forebay residence times compared to those reported in the 2012 study at all three Snake River dams. At LGS and LMN, project passage times were also similar between 2012 and 2013; however, we did observe a longer median project passage time in 2013 compared to 2012 at LGR (Mann-Whitney rank sum test, $\mathrm{P}<0.01$ ). In addition, we found longer tailrace egress times in 2013 when compared with 2012 results at all three dams (Mann-Whitney rank sum test, $\mathrm{P}<0.001$ ). As mentioned previously, mean river discharge was higher in 2012 than in 2013 and may have been 
associated with differences in tailrace egress times and LGR project passage times between years; but there does not appear to be a distinct pattern in tailrace egress time throughout the duration of the study period (Figure 4.6).

\subsection{Population Abundance}

Using the number of tagged and untagged kelts sampled in the LGR JFF and the proportion of kelts tagged with acoustic transmitters that passed LGR through the JBS, we estimated 19,630 kelts passed LGR in 2013. This population abundance was comprised of an estimated 11,811 unclipped and 7,819 adipose-clipped steelhead kelts. From the Lincoln-Petersen method, the unclipped kelt population abundance at the time of tagging was estimated to be 14,022 (SE = 4,567). Multiplying this estimate by the pooled survival probability from release to LGR of all tributary groups (0.838), we obtained an estimate of 11,750 unclipped kelts, which substantiates the estimate we obtained using the JBS passage proportion.

Our estimate of 19,630 marked and unmarked kelts that passed LGR in 2013 is $49 \%$ of the number of kelts we estimated to have passed LGR in $2012(N=39,910$; Colotelo et al. 2013). This difference between years is comparable to the difference observed in the numbers of adipose-clipped and unclipped adult steelhead counted passing LGR on their way to the spawning grounds in 2011 and 2012 when 183,648 and 110,675 passed LGR, respectively (Fish Passage Center; www.fpc.org). Based on these numbers alone, we would expect there to be about $40 \%$ fewer kelts returning to LGR in 2013 compared to 2012 (if all other conditions were similar between years) since there were $40 \%$ fewer steelhead adults that migrated above LGR. However, as mentioned previously, river conditions were less favorable (lower discharge, warmer water temperatures) in 2013 than in 2012, which may have contributed to the lower percentage of steelhead that returned to LGR as kelts in 2013. 


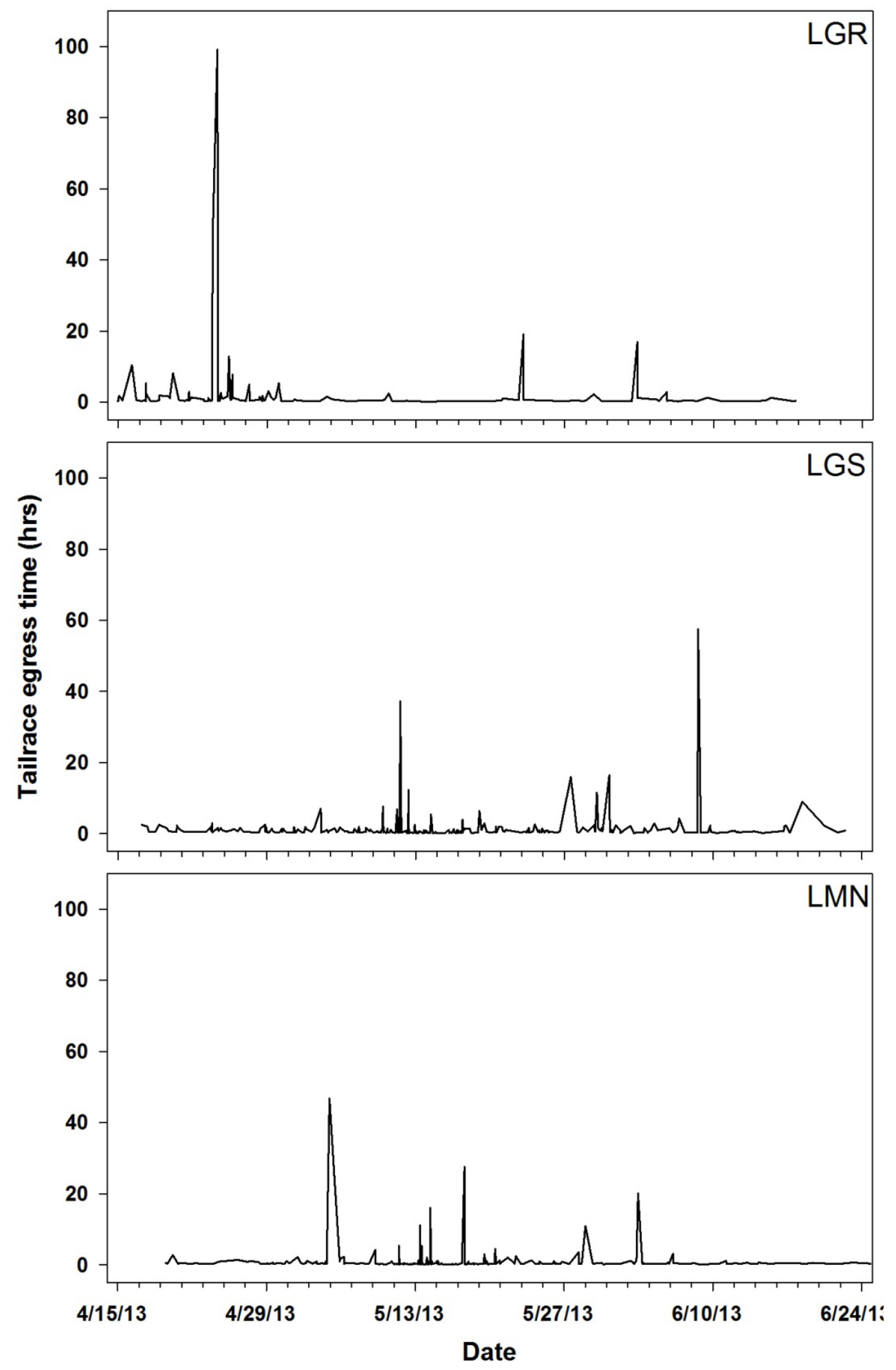

Figure 4.6. Tailrace egress time (hours) of steelhead kelts that passed Lower Granite (LGR), Little Goose (LGS), and Lower Monumental (LMN) dams over time in 2013. 


\subsection{Conclusions}

The results of this study provide information about the migration success, survival, route of passage, and route-specific survival for steelhead kelts that migrated through the Snake and Columbia rivers from Snake River tributaries to BON in 2013. This was the second year of a study conducted to measure these metrics since the installation of spillway weirs at many FCRPS dams. Migration success and survival was highest in 2012, and survival was generally higher and travel rates were faster for Snake River kelts in 2013 compared to the results obtained in 2001 and 2002. Spillway weirs were again the primary route of passage for steelhead kelts in the Snake River. Spillway weirs and the JBSs generally provided the highest estimated dam passage survival for steelhead kelts. We observed a decline in estimated survival through traditional deep spill routes from results obtained in 2012. In fact, survival was lowest through traditional spill routes at LGS and LMN. JBS- and turbine-specific survival estimates should be interpreted with caution, particularly at LGR, because of low sample sizes. Discharge was lower, water temperature was generally higher, and a higher proportion of the tagged kelts were in fair condition in 2013 compared to 2012. These factors may have contributed to the lower survival and slower travel rates observed in 2013.

The results of this two-year study have contributed to the understanding of the effects of FCRPS dams on the migration and survival of steelhead kelts in the Snake and Columbia rivers. However, additional analyses of data collected during this study may provide further insight into the conditions (e.g., dam operations) that optimize dam passage (i.e., route, travel time, and survival). Future field studies should focus on sampling over the full seaward-migration period and include additional tributaries of the Snake River to include a broader section of the Snake River steelhead population. 


\subsection{References}

Boggs CT and CA Peery. 2004. Steelhead (Oncorhynchus mykiss) kelt abundance, condition, passage, and survival in the Lower Snake and Columbia Rivers, 2003. Report No. ICFWRU 2004-1, prepared for the U.S. Army Corps of Engineers, Walla Walla District, by Idaho Cooperative Fish and Wildlife Research Unit, University of Idaho, Moscow, Idaho.

Brannon EL, MS Powell, TP Quinn, and A Talbot. 2004. Population structure of Columbia River Basin Chinook salmon and steelhead trout. Reviews in Fisheries Science 12(2-3):99-232.

Budy PG, P Thiede, N Bouwes, CE Petrosky, and H Schaller. 2002. Evidence linking delayed mortality of Snake River salmon to their earlier hydrosystem experience. North American Journal of Fisheries Management 22:35-51.

Buelow JL. 2011. Physiological Characteristics of Steelhead Kelt (Oncorhynchus mykiss) in the Snake River, Idaho. Master's thesis, University of Idaho, Moscow.

Busby PJ, TC Wainwright, GJ Bryant, LJ Lierheimer, RS Waples, FW Waknitz, and IV Lagomarsino. 1996. Status review of west coast steelhead from Washington, Idaho, Oregon, and California. NOAA Technical Memorandum NMFS-NWFSC-27, National Marine Fisheries Service, Northwest Fisheries Science Center, Seattle, Washington, and National Marine Fisheries Service, Southwest Region, Long Beach, California. Available at http://www.nwfsc.noaa.gov/assets/25/

4245_06172004_122523_steelhead.pdf (December 2012).

Chapman DW. 1986. Salmon and steelhead abundance in the Columbia River in the nineteenth century. Transactions of the American Fisheries Society 115:662-670.

Colotelo AH, BW Jones, RA Harnish, GA McMichael, KD Ham, ZD Deng, GM Squeochs, RS Brown, MA Weiland, GR Ploskey, X Li, and T Fu. 2013. Passage Distribution and Federal Columbia River Power System Survival for Steelhead Kelts Tagged Above and at Lower Granite Dam. PNNL-22101, prepared for the U.S. Army Corps of Engineers, Walla Walla District, Contract Number W912EF-08D-0004, by Pacific Northwest National Laboratory, Richland, Washington.

Deng Z, MA Weiland, TJ Carlson, and MB Eppard. 2010. Design and Instrumentation of a Measurement and Calibration System for an Acoustic Telemetry System. Sensors 10(4):3090-3099.

Deng Z, MA Weiland, T Fu, TA Seim, BL Lamarche, EY Choi, TJ Carlson, and MB Eppard. 2011. A cabled acoustic telemetry system for detecting and tracking juvenile salmon: Part 2. Three-dimensional tracking and passage outcomes. Sensors 11(6):5661-5676.

Endangered Species Act of 1973. 1973. Public Law 93-205, as amended, 16 USC 1531 et seq.

Fleming IA and MR Reynolds. 2004. "Salmon breeding systems.” In Evolution Illuminated: Salmon and Their Relatives, AP Henry and SC Stearns (eds.), pp. 264-294. Oxford University Press, Oxford, United Kingdom. 
Harnish RA, AH Colotelo, X Li, KD Ham, and ZD Deng. In Draft. Factors affecting route selection and survival of steelhead kelts at Snake River dams in 2012 and 2013. PNNL-XXXXX, prepared for the U.S. Army Coprps of Engineers, Walla Walla District, by Pacific Northwest National Laboratory, Richland, Washington.

Hatch DR, R Branstetter, and S Narum. 2003. Evaluate Steelhead (Oncorhynchus mykiss) Kelt Outmigration from Lower Granite Dam to Bonneville Dam and test the Use of Transportation to Increase Returns of Repeat Spawners. Report to the U.S. Army Corp of Engineers, Walla Walla, Washington, Contract No. DACW68-00-C-0027, prepared by the Columbia River Inter-Tribal Fish Commission, Portland, Oregon.

High B, CA Peery, and D H Bennett. 2006. Temporary staging of Columbia River summer steelhead in coolwater areas and its effect on migration rates. Transactions of the North American Fisheries Society 135:519-528.

Keefer ML, RH Wertheimer, AF Evans, CT Boggs, and CA Peery. 2008. Iteroparity in Columbia River summer-run steelhead (Oncorhynchus mykiss): implications for conservation. Canadian Journal of Fisheries and Aquatic Sciences 65(12):2592-2605.

Kraabol M, SI Johnsen, J Museth, and OT Sandlund. 2009. Conserving iteroparous fish stocks in regulated rivers: The need for a broader perspective! Fisheries Management and Ecology 16:337-340.

Li T and JJ Anderson. 2009. The vitality model: a way to understand population survival and demographic heterogeneity. Theoretical Population Biology 76:118-131.

Lichatowich JA. 2001. Salmon without Rivers: A History of the Pacific Salmon Crisis. Island Press, Washington, D.C.

Lincoln FC. 1930. Calculating waterfowl abundance on the basis of banding returns. United States Department of Agriculture Circular 118:1-4.

Long JB, and LE Griffin. 1937. Spawning and migratory habits of Columbia River steelhead trout as determined by scale studies. Copeia 1937:62.

McClure MM, EE Holmes, BL Sanderson, and CE Jordan. 2003. A large-scale multispecies status assessment: Anadromous salmonids in the Columbia River basin. Ecological Applications 13(4):964-989.

Muir WD, SG Smith, JG Williams, EE Hockersmith, and JR Skalski. 2001. Survival estimates for migrant yearling Chinook salmon and steelhead tagged with passive integrated transponders in the lower Snake and lower Columbia rivers, 1993-1998. North American Journal of Fisheries Management 21:269-282.

Narum SR, D Hatch, AJ Talbot, P Moran, and MS Powell. 2008. Iteroparity in complex mating systems of steelhead Oncorhynchus mykiss (Walbaum). Journal of Fish Biology 72(1):45-60.

Nehlsen W, JE Williams, and JA Lichatowich. 1991. Pacific salmon at the crossroads: Stocks at risk from California, Oregon, Idaho, and Washington. Fisheries 16(2):4-21. 
NMFS (National Marine Fisheries Service). 2004. Endangered Species Act status of West Coast salmonids, June 17, 2004. National Marine Fisheries Service, Northwest Region, Portland, Oregon. Available at http://www.nwr.noaa.gov (December 2012).

NOAA (National Oceanic and Atmospheric Administration). 2008. Consultation on Remand for Operation of the Federal Columbia River Power System, 11 Bureau of Reclamation Projects in the Columbia Basin and ESA Section 10(a)(I)(A) Permit for Juvenile Fish Transportation Program [Revised and reissued pursuant to court order, NWF v. NMFS, Civ. No. CV 01-640-RE (D. Oregon)]. Endangered Species Act Section 7(a)(2) Consultation Biological Opinion and Magnuson-Stevens Fishery Conservation and Management Act Essential Fish Habitat Consultation, May 5, 2008. NOAA National Marine Fisheries Service, Northwest Region, Seattle, Washington.

Petersen CGJ. 1896. The yearly immigration of young plaice into the Limfjord from the German Sea. Report of the Danish Biological Station (1895) 6:5-84.

Rakowski CL, JA Serkowski, MC Richmond, and WA Perkins. 2010. Determining Columbia and Snake River Project Tailrace and Forebay Zones of Hydraulic Influence Using MASS2 Modeling. PNNL-20030, Pacific Northwest National Laboratory, Richland, Washington.

Raymond HL. 1969. Effect of John Day Reservoir on the migration rate of juvenile Chinook salmon in the Columbia River. Transactions of the American Fisheries Society 98:513-514.

Raymond HL. 1979. Effects of dams and impoundments on migrations of juvenile Chinook salmon and steelhead from the Snake River, 1966 to 1975. Transactions of the American Fisheries Society 108(6):505-529.

Seamons TR and TP Quinn. 2010. Sex-specific patterns of lifetime reproductive success in single and repeat breeding steelhead trout (Oncorhynchus mykiss). Behavioral Ecology and Sociobiology 64:505-513.

Skalski JR, RA Buchanan, RL Townsend, TW Steig, and S Hemstrom. 2009. A multiple-release model to estimate route-specific and dam passage survival at a hydroelectric project. North American Journal of Fisheries Management 29:670-679.

Skalski JR, RL Townsend, TW Steig, and S Hemstrom. 2010. Comparison of two alternative approaches for estimating dam passage survival of salmon smolts. North American Journal of Fisheries Management 30:831-839.

Smith SG, WD Muir, JG Williams, and JR Skalski. 2002. Factors associated with travel time and survival of migrant yearling Chinook salmon and steelhead in the lower Snake River. North American Journal of Fisheries Management 22:385-405.

Summerfelt RC and LS Smith. 1990. “Anesthesia, Surgery, and Related Techniques.” In Methods for Fish Biology, CB Schreck and PB Moyle (eds.), pp. 213-263. American Fisheries Society, Bethesda, Maryland. 
Titzler PS, GA McMichael, and JA Carter. 2010. Autonomous acoustic receiver deployment and mooring techniques for us in large rivers and estuaries. North American Journal of Fisheries Management 30(4):853-859.

Weiland MA, Z Deng, TA Seim, BL Lamarche, EY Choi, T Fu, TJ Carlson, AI Thronas, and MB Eppard. 2011. A cabled acoustic telemetry system for detecting and tracking juvenile salmon: Part 1. Engineering design and instrumentation. Sensors 11(6):5645-5660.

Wertheimer RH. 2007. Evaluation of a surface flow bypass system for steelhead kelt passage at Bonneville Dam, Washington. North American Journal of Fisheries Management 27(1):21-29.

Wertheimer RH and AF Evans. 2005. Downstream passage of steelhead kelts through hydroelectric dams on the lower Snake and Columbia rivers. Transactions of the American Fisheries Society 134(4):853-865. 
Appendix A

Hydrophone and Autonomous Node Deployment Tables and Locations of Fish Collection Sites 


\section{Appendix A}

\section{Hydrophone and Autonomous Node Deployment Tables and Locations of Fish Collection Sites}

Table A.1. Cabled hydrophone locations at Lower Granite Dam in 2013. Hydrophones were deployed on 7 March 2013.

\begin{tabular}{llccl}
\hline \multicolumn{1}{c}{$\begin{array}{c}\text { Hydrophone } \\
\text { Name }\end{array}$} & $\begin{array}{c}\text { Latitude } \\
\text { (Degrees North) }\end{array}$ & $\begin{array}{c}\text { Longitude } \\
\text { (Degrees West) }\end{array}$ & $\begin{array}{c}\text { Elevation }(\mathrm{ft}) \\
\text { (NGVD29) }\end{array}$ & Array Location \\
\hline S08S & 46.65998667 & -117.4286809 & 722.6 & Spillway \\
\hline S08D & 46.65998667 & -117.4286809 & 695.3 & \\
\hline S07 08S & 46.65984214 & -117.4288243 & 722.6 & \\
S07 08D & 46.65984214 & -117.4288243 & 695.4 & \\
S06 07S & 46.65969717 & -117.4289683 & 722.7 & \\
S06 07D & 46.65969717 & -117.4289683 & 695.7 & \\
\hline S05 06S & 46.65955209 & -117.4291110 & 722.9 & \\
S05 06D & 46.65955209 & -117.4291110 & 695.8 & \\
S04 05S & 46.65940624 & -117.4292554 & 722.9 & \\
\hline S04 05D & 46.65940624 & -117.4292554 & 695.8 & \\
S03 04S & 46.65926284 & -117.4293973 & 727.3 & \\
\hline S03 04D & 46.65926287 & -117.4293973 & & \\
S02 03S & 46.65911294 & -117.4295452 & 722.8 & \\
S02 03D & 46.65911294 & -117.4295452 & 695.5 & \\
RSW S 01 & 46.65854941 & -117.4292647 & 618.2 & Spillway weir approach \\
RSW S 02 & 46.65856943 & -117.4292301 & 618.2 & \\
RSW S 03 & 46.65857960 & -117.4292731 & 618.2 & \\
RSW S 04 & 46.65856619 & -117.4292560 & 623.6 & \\
P06S & 46.65868149 & -117.4298670 & 723.4 & Powerhouse \\
\hline P06 D & 46.65866020 & -117.4298218 & 639.1 & \\
P05 06S & 46.65848276 & -117.4300641 & 723.4 & \\
P05 06D & 46.65846147 & -117.4300188 & 639.1 & \\
P04 05S & 46.65827777 & -117.4302663 & 723.4 & \\
P04 05D & 46.65825648 & -117.4302211 & 639.2 & \\
P03 04S & 46.65807321 & -117.4304676 & 722.7 & \\
\hline P03 04D & 46.65805192 & -117.4304223 & 638.5 & \\
P02 03S & 46.65787033 & -117.4306678 & 723.0 & \\
P02 03D & 46.65784913 & -117.4306226 & 638.8 & \\
P01 02S & 46.65766579 & -117.4308698 & 723.0 & \\
P01 02D & 46.65764450 & -117.4308244 & 638.7 & \\
P00 01S & 46.65746829 & -117.4310725 & 723.1 & \\
P00 01D & 46.65744690 & -117.4310270 & 638.6 & \\
\hline & & & & \\
\end{tabular}


Table A.2. Cabled hydrophone locations at Little Goose Dam in 2013. Hydrophones were deployed on 31 March 2013.

\begin{tabular}{|c|c|c|c|c|}
\hline $\begin{array}{l}\text { Hydrophone } \\
\text { Name }\end{array}$ & $\begin{array}{c}\text { Latitude } \\
\text { (Degrees North) }\end{array}$ & $\begin{array}{c}\text { Longitude } \\
\text { (Degrees West) }\end{array}$ & $\begin{array}{c}\text { Elevation (ft) } \\
\text { (NGVD29) }\end{array}$ & Array Location \\
\hline S08S & 46.58616543 & -118.0273789 & 624.0 & Spillway \\
\hline S08D & 46.58616543 & -118.0273789 & 596.9 & \\
\hline S07 08S & 46.58599119 & -118.0273299 & 623.7 & \\
\hline S0 08D & 46.58599119 & -118.0273299 & 597.0 & \\
\hline S06 07S & 46.58581759 & -118.0272810 & 623.9 & \\
\hline S06 07D & 46.58581759 & -118.0272810 & 597.0 & \\
\hline S05 06S & 46.58564690 & -118.0272337 & 624.0 & \\
\hline S05 06D & 46.58564690 & -118.0272337 & 597.1 & \\
\hline S04 05S & 46.58547392 & -118.0271846 & 624.0 & \\
\hline S04 05D & 46.58547392 & -118.0271846 & 597.0 & \\
\hline S03 04S & 46.58530149 & -118.0271363 & 624.1 & \\
\hline S03 04D & 46.58530149 & -118.0271363 & 597.2 & \\
\hline S02 03S & 46.58512963 & -118.0270884 & 623.8 & \\
\hline S02 03D & 46.58512963 & -118.0270884 & 596.9 & \\
\hline S01 02S & 46.58495583 & -118.0270391 & 622.5 & \\
\hline S01 02D & 46.58495583 & -118.0270391 & 595.4 & \\
\hline S01S & 46.58478224 & -118.0269909 & 624.3 & \\
\hline S01D & 46.58478224 & -118.0269909 & 597.2 & \\
\hline P06S & 46.58467372 & -118.0268723 & 622.9 & Powerhouse \\
\hline P06D & 46.58468104 & -118.0268229 & 539.8 & \\
\hline P05 06S & 46.58443168 & -118.0268053 & 623.4 & \\
\hline P05 06D & 46.58443898 & -118.0267560 & 540.4 & \\
\hline P04 05S & 46.58419034 & -118.0267375 & 623.5 & \\
\hline P04 05D & 46.58419772 & -118.0266880 & 540.1 & \\
\hline P03 04S & 46.58394647 & -118.0266694 & 623.5 & \\
\hline P03 04D & 46.58395377 & -118.0266201 & 540.5 & \\
\hline P02 03S & 46.58370405 & -118.0266013 & 623.4 & \\
\hline P02 03D & 46.58371143 & -118.0265519 & 540.3 & \\
\hline P01 02S & 46.58346188 & -118.0265329 & 623.1 & \\
\hline P01 02D & 46.58346926 & -118.0264836 & 540.2 & \\
\hline P00 01S & 46.58321938 & -118.0264624 & 623.5 & \\
\hline P00 01D & 46.58322679 & -118.0264129 & 540.4 & \\
\hline FLS & 46.58292047 & -118.0263206 & 626.4 & Fish ladder \\
\hline
\end{tabular}


Table A.3. Cabled hydrophone locations at Lower Monumental Dam in 2013. Hydrophones were deployed on 31 March 2013.

\begin{tabular}{|c|c|c|c|c|}
\hline $\begin{array}{l}\text { Hydrophone } \\
\text { Name }\end{array}$ & $\begin{array}{c}\text { Latitude } \\
\text { (Degrees } \\
\text { North) }\end{array}$ & $\begin{array}{c}\text { Longitude } \\
\text { (Degrees } \\
\text { West) }\end{array}$ & $\begin{array}{c}\text { Elevation (ft) } \\
\text { (NGVD29) }\end{array}$ & Array Location \\
\hline FLN & 46.56455186 & -118.5401841 & 531.1 & North fish ladder \\
\hline P00 01S & 46.56418889 & -118.5396474 & 527.3 & Powerhouse \\
\hline P00 01D & 46.56420973 & -118.5396080 & 443.3 & \\
\hline P01 02S & 46.56400256 & -118.5394456 & 527.3 & \\
\hline P01 02D & 46.56402340 & -118.5394062 & 443.4 & \\
\hline P02 03S & 46.56380569 & -118.5392326 & 527.2 & \\
\hline P02 03D & 46.56382662 & -118.5391931 & 443.1 & \\
\hline P03 04S & 46.56360717 & -118.5390175 & 527.2 & \\
\hline P03 04D & 46.56362800 & -118.5389782 & 443.2 & \\
\hline P04 05S & 46.56340984 & -118.5388042 & 527.3 & \\
\hline P04 05D & 46.56343068 & -118.5387648 & 443.3 & \\
\hline P05 06S & 46.56321168 & -118.5385895 & 527.4 & \\
\hline P05 06D & 46.56323260 & -118.5385501 & 443.3 & \\
\hline P06S & 46.56301499 & -118.5383762 & 527.4 & \\
\hline P06D & 46.56303591 & -118.5383368 & 443.4 & \\
\hline RSW N 01 & 46.56323363 & -118.5377934 & 425.7 & Spillway weir approach \\
\hline RSW N 02 & 46.56324192 & -118.5377768 & 430.0 & \\
\hline RSW N 03 & 46.56323932 & -118.5377650 & 423.7 & \\
\hline RSW N 04 & 46.56325183 & -118.5377829 & 424.7 & \\
\hline RSW S 01 & 46.56300257 & -118.5376657 & 429.4 & \\
\hline RSW S 02 & 46.56302216 & -118.5376618 & 428.4 & \\
\hline RSW S 03 & 46.56301586 & -118.5376513 & 433.6 & \\
\hline RSW S 04 & 46.56301395 & -118.5376419 & 428.7 & \\
\hline S06 07S & 46.56261439 & -118.5380490 & 526.8 & Spillway \\
\hline S06 07D & 46.56261439 & -118.5380490 & 497.9 & \\
\hline S05 06S & 46.56247364 & -118.5378969 & 526.8 & \\
\hline S05 06D & 46.56247364 & -118.5378969 & 498.0 & \\
\hline S04 05S & 46.56233307 & -118.5377448 & 526.8 & \\
\hline S04 05D & 46.56233307 & -118.5377448 & 497.9 & \\
\hline S03 04S & 46.56219314 & -118.5375935 & 526.9 & \\
\hline S03 04D & 46.56219314 & -118.5375935 & 498.0 & \\
\hline S02 03S & 46.56205257 & -118.5374415 & 526.9 & \\
\hline S02 03D & 46.56205257 & -118.5374415 & 497.9 & \\
\hline S01 02S & 46.56191116 & -118.5372882 & 526.7 & \\
\hline S01 02D & 46.56191116 & -118.5372882 & 497.7 & \\
\hline S00 01S & 46.56176912 & -118.5371344 & 526.9 & \\
\hline S00 01D & 46.56176912 & -118.5371344 & 498.0 & \\
\hline FLS & 46.56159715 & -118.5369512 & 531.3 & South fish ladder \\
\hline
\end{tabular}


Table A.4. Approximate global positioning system coordinates of autonomous hydrophone nodes deployed in the Snake, Clearwater, and Columbia rivers in 2013. Array_Node is a concatenation of array name and autonomous node number. Array name is a concatenation of river name (CR for Columbia River), and rkm from the array to the mouth of the Columbia River. Nodes within each array are generally numbered from the north shore to the south shore. Note: the CR113.0 array was removed on 5/15/2013 after which the CR152 array was deployed on 5/16/2013.

\begin{tabular}{|c|c|c|c|c|c|}
\hline Array_Node & Array Function & $\begin{array}{c}\text { Latitude } \\
\text { (Degrees North) }\end{array}$ & $\begin{array}{c}\text { Longitude } \\
\text { (Degrees West) }\end{array}$ & $\mathrm{rkm}$ & $\begin{array}{c}\text { Deployment } \\
\text { Date }\end{array}$ \\
\hline CR743.0_01 & Clearwater mouth & 46.4258896 & -117.0713279 & 743 & $4 / 11 / 2013$ \\
\hline CR743.0_02 & & 46.42537625 & -117.0707588 & 743 & 4/11/2013 \\
\hline CR743.0_03 & & 46.42488335 & -117.0700750 & 743 & 4/11/2013 \\
\hline CR696.0_01 & LGR forebay & 46.65861708 & -117.4151533 & 696 & $4 / 12 / 2013$ \\
\hline CR696.0_02 & & 46.65721583 & -117.4165254 & 696 & $4 / 12 / 2013$ \\
\hline CR696.0_03 & & 46.65579375 & -117.4176846 & 696 & $4 / 12 / 2013$ \\
\hline CR696.0_04 & & 46.65455753 & -117.4186659 & 696 & $4 / 12 / 2013$ \\
\hline CR693.0_01 & LGR tailrace & 46.67293668 & -117.4466009 & 693 & 4/12/2013 \\
\hline CR693.0_02 & & 46.67279665 & -117.4480759 & 693 & $4 / 12 / 2013$ \\
\hline CR636.0_01 & LGS forebay & 46.58926112 & -118.0168925 & 636 & $4 / 11 / 2013$ \\
\hline CR636.0_02 & & 46.58823972 & -118.0162978 & 636 & 4/11/2013 \\
\hline CR636.0_03 & & 46.58707195 & -118.0156900 & 636 & $4 / 11 / 2013$ \\
\hline CR636.0_04 & & 46.58603083 & -118.0155522 & 636 & $4 / 11 / 2013$ \\
\hline CR634.0_01 & LGS tailrace & 46.58094222 & -118.0466570 & 634 & $4 / 11 / 2013$ \\
\hline CR634.0_02 & & 46.58038335 & -118.0457789 & 634 & $4 / 11 / 2013$ \\
\hline CR634.0_03 & & 46.57981638 & -118.0449525 & 634 & $4 / 11 / 2013$ \\
\hline CR602.0_01 & LMN mid res. & 46.58176083 & -118.3940736 & 602 & 4/14/2013 \\
\hline CR602.0_02 & & 46.58067722 & -118.3942967 & 602 & 4/14/2013 \\
\hline CR602.0_03 & & 46.57979638 & -118.3942197 & 602 & 4/14/2013 \\
\hline CR602.0_04 & & 46.57872498 & -118.3942686 & 602 & $4 / 14 / 2013$ \\
\hline CR590.0_01 & LMN forebay & 46.56752610 & -118.5313650 & 590 & 4/14/2013 \\
\hline CR590.0_02 & & 46.56681638 & -118.5298903 & 590 & 4/14/2013 \\
\hline CR590.0_03 & & 46.56591917 & -118.5288292 & 590 & $4 / 14 / 2013$ \\
\hline CR590.0_04 & & 46.56494223 & -118.5280095 & 590 & 4/14/2013 \\
\hline CR587.0_01 & LMN tailrace & 46.54741833 & -118.5554108 & 587 & 4/14/2013 \\
\hline CR587.0_02 & & 46.54660108 & -118.5559911 & 587 & 4/14/2013 \\
\hline CR587.0_03 & & 46.54699252 & -118.5533978 & 587 & 4/14/2013 \\
\hline CR562.0_01 & IHR mid res. & 46.37897138 & -118.6953459 & 562 & 4/14/2013 \\
\hline CR562.0_02 & & 46.37867030 & -118.6943131 & 562 & 4/14/2013 \\
\hline CR562.0_03 & & 46.37842778 & -118.6932406 & 562 & 4/14/2013 \\
\hline CR562.0_04 & & 46.37836110 & -118.6922853 & 562 & 4/14/2013 \\
\hline CR539.0_01 & IHR forebay & 46.25282527 & -118.8700603 & 539 & 4/14/2013 \\
\hline CR539.0_02 & & 46.25178195 & -118.8688336 & 539 & $4 / 14 / 2013$ \\
\hline CR539.0_03 & & 46.25126417 & -118.8684811 & 539 & 4/14/2013 \\
\hline CR539.0_04 & & 46.24986057 & -118.8678703 & 539 & $4 / 14 / 2013$ \\
\hline CR525.0_01 & Snake mouth & 46.21617264 & -119.0243824 & 525 & 4/14/2013 \\
\hline CR525.0_02 & & 46.21534166 & -119.0231703 & 525 & 4/14/2013 \\
\hline
\end{tabular}


Table A.4. (contd)

\begin{tabular}{|c|c|c|c|c|c|}
\hline Array_Node & Array Function & $\begin{array}{c}\text { Latitude } \\
\text { (Degrees North) }\end{array}$ & $\begin{array}{c}\text { Longitude } \\
\text { (Degrees West) }\end{array}$ & rkm & $\begin{array}{c}\text { Deployment } \\
\text { Date }\end{array}$ \\
\hline CR525.0_03 & & 46.21490968 & -119.0225910 & 525 & $4 / 14 / 2013$ \\
\hline CR525.0_04 & & 46.21439918 & -119.0217961 & 525 & 4/14/2013 \\
\hline CR236.0_01 & BON forebay & 45.65097400 & -121.9203458 & 236 & $3 / 13 / 2013$ \\
\hline CR236.0_02 & & 45.65043500 & -121.9198845 & 236 & 3/13/2013 \\
\hline CR236.0_03 & & 45.64985990 & -121.9193207 & 236 & 3/13/2013 \\
\hline CR236.0_04 & & 45.64932090 & -121.9188595 & 236 & $3 / 13 / 2013$ \\
\hline CR152.0_01 & CR at km 152 & 45.75221670 & -122.7590167 & 152 & $5 / 16 / 2013$ \\
\hline CR152.0_02 & & 45.75200000 & -122.7599833 & 152 & $5 / 16 / 2013$ \\
\hline CR152.0_03 & & 45.75176660 & -122.7610000 & 152 & $5 / 16 / 2013$ \\
\hline CR152.0_04 & & 45.75156670 & -122.7621167 & 152 & $5 / 16 / 2013$ \\
\hline CR152.0_05 & & 45.75131660 & -122.7633500 & 152 & $5 / 16 / 2013$ \\
\hline CR152.0_06 & & 45.75100000 & -122.7647000 & 152 & $5 / 16 / 2013$ \\
\hline CR152.0_07 & & 45.75071670 & -122.7659167 & 152 & $5 / 16 / 2013$ \\
\hline CR152.0_08 & & 45.75039997 & -122.7672500 & 152 & $5 / 16 / 2013$ \\
\hline CR126.0_01 & $\mathrm{CR}$ at $\mathrm{km} 126$ & 45.97245000 & -122.8251833 & 126 & 4/4/2013 \\
\hline CR126.0_02 & & 45.97235000 & -122.8258000 & 126 & $4 / 4 / 2013$ \\
\hline CR126.0_02 & & 45.97225000 & -122.8260500 & 126 & $4 / 25 / 2013$ \\
\hline CR126.0_03 & & 45.97185000 & -122.8261833 & 126 & 4/4/2013 \\
\hline CR126.0_04 & & 45.97135000 & -122.8269833 & 126 & 4/4/2013 \\
\hline CR126.0_05 & & 45.97055000 & -122.8276000 & 126 & $4 / 4 / 2013$ \\
\hline CR126.0_06 & & 45.97010000 & -122.8284000 & 126 & $4 / 4 / 2013$ \\
\hline CR126.0_07 & & 45.96996670 & -122.8294500 & 126 & $4 / 4 / 2013$ \\
\hline CR126.0_08 & & 45.96961670 & -122.8301500 & 126 & 4/4/2013 \\
\hline CR113.0_01 & CR at km 113 & 46.05613700 & -122.8727154 & 113 & $4 / 4 / 2013$ \\
\hline CR113.0_02 & & 46.05933330 & -122.8806833 & 113 & 4/4/2013 \\
\hline CR113.0_03 & & 46.05933330 & -122.8820167 & 113 & 4/4/2013 \\
\hline CR113.0_04 & & 46.05916670 & -122.8831167 & 113 & 4/4/2013 \\
\hline CR113.0_04 & & 46.05803300 & -122.8829300 & 113 & 4/29/2013 \\
\hline CR113.0_05 & & 46.05911670 & -122.8841000 & 113 & $4 / 4 / 2013$ \\
\hline CR113.0_05 & & 46.05785000 & -122.8841670 & 113 & 4/29/2013 \\
\hline CR113.0_06 & & 46.05903330 & -122.8851500 & 113 & 4/4/2013 \\
\hline CR113.0_07 & & 46.05890000 & -122.8860833 & 113 & $4 / 4 / 2013$ \\
\hline CR113.0_08 & & 46.05878330 & -122.8871167 & 113 & $4 / 4 / 2013$ \\
\hline CR113.0_09 & & 46.05865000 & -122.8881333 & 113 & $4 / 4 / 2013$ \\
\hline CR113.0_10 & & 46.05851670 & -122.8891000 & 113 & 4/4/2013 \\
\hline
\end{tabular}


Table A.5. Approximate global positioning system coordinates of sites where steelhead kelts were collected for tagging in 2013.

\begin{tabular}{lccc}
\hline \multicolumn{1}{c}{ Location } & $\begin{array}{c}\text { Latitude } \\
\text { (Degrees North) }\end{array}$ & $\begin{array}{c}\text { Longitude } \\
\text { (Degrees West) }\end{array}$ & rkm \\
\hline Lower Granite Dam juvenile fish facility & 46.66011900 & -117.4358080 & 695 \\
\hline Asotin Creek weir & 46.32559167 & -117.1074806 & 761 \\
George Creek weir & 46.31342500 & -117.1113611 & 762 \\
\hline Potlatch River weir & 46.79846670 & -116.4193083 & 836 \\
Joseph Creek weir & 46.02762778 & -117.0178944 & 804 \\
Fish Creek weir & 46.33928611 & -115.3539583 & 944 \\
\hline
\end{tabular}


Appendix B

Steelhead Kelt Data Collected at Tagging 
Table B.1. Data collected at tagging from the steelhead kelts included in this study. Information includes tagging site (LGR = Lower Granite Dam, ASO = Asotin Creek, PEW = Potlatch River, JOS = Joseph Creek, FC = Fish Creek), PIT-tag code, JSATS tag code, condition, sex, status of the adipose fin, length, weight, release date, and the release rkm as measured from the mouth of the Columbia River).

\begin{tabular}{|c|c|c|c|c|c|c|c|c|c|}
\hline $\begin{array}{l}\text { Tagging } \\
\text { Site }\end{array}$ & PIT Tag \# & JSATS Tag \# & $\begin{array}{l}\text { Condition } \\
\text { (Good/Fair) }\end{array}$ & $\begin{array}{c}\text { Sex } \\
\text { (Male/Female) }\end{array}$ & $\begin{array}{c}\text { Adipose Fin } \\
\text { (Clipped/Intact) }\end{array}$ & $\begin{array}{l}\text { Length } \\
\text { (cm) }\end{array}$ & $\begin{array}{l}\text { Weight } \\
\text { (kg) }\end{array}$ & Release Date & $\begin{array}{c}\text { Release } \\
\text { rkm }\end{array}$ \\
\hline LGR & 3D9.1C2DDBF829 & G722990C2 & Fair & Female & Clipped & 60.0 & 1.70 & $4 / 13 / 2013$ & 695 \\
\hline LGR & 3D9.1C2DB0BE4A & G720A3245 & Fair & Female & Intact & 57.0 & 1.20 & 4/14/2013 & 695 \\
\hline LGR & 3D9.1C2D240B13 & G721657BE & Fair & Female & Intact & 68.0 & 2.19 & 4/14/2013 & 695 \\
\hline LGR & 3D9.1C2DDC1C10 & G72105375 & Fair & Female & Clipped & 69.0 & 2.58 & 4/14/2013 & 695 \\
\hline LGR & 3D9.1C2DDC16D3 & G72299D3F & Good & Female & Intact & 59.0 & 1.59 & $4 / 16 / 2013$ & 695 \\
\hline LGR & 3D9.1C2D4755FE & G7209DDB8 & Good & Female & Intact & 62.0 & 1.87 & $4 / 17 / 2013$ & 695 \\
\hline LGR & 3D9.1C2D483E09 & G72155D95 & Good & Female & Intact & 68.0 & 2.16 & 4/17/2013 & 695 \\
\hline LGR & 3D9.1C2DDB8D96 & G721516F3 & Good & Female & Intact & 67.0 & 2.27 & 4/19/2013 & 695 \\
\hline LGR & 3D9.1C2DDBCACC & G721137B5 & Good & Female & Intact & 72.0 & 2.70 & $4 / 22 / 2013$ & 695 \\
\hline LGR & 3D9.1C2DDBCCF4 & G7210F7BB & Good & Female & Clipped & 79.0 & 3.40 & 4/22/2013 & 695 \\
\hline LGR & 3D9.1C2DDBC0F7 & G7209FD9B & Fair & Female & Intact & 64.0 & 1.77 & $4 / 23 / 2013$ & 695 \\
\hline LGR & 3D9.1C2DDBD70C & G7216747F & Fair & Female & Intact & 58.0 & 1.39 & 4/23/2013 & 695 \\
\hline LGR & 3D9.1C2DDBF196 & G7208DD7C & Good & Female & Clipped & 65.0 & 1.72 & 4/23/2013 & 695 \\
\hline LGR & 3D9.1C2DDC22A5 & G7215D978 & Fair & Female & Intact & 67.0 & 2.11 & 4/24/2013 & 695 \\
\hline LGR & 3D9.1C2DDBBFCF & G720A9056 & Fair & Female & Clipped & 65.0 & 2.04 & $4 / 24 / 2013$ & 695 \\
\hline LGR & 3D9.1C2DDBAFAF & G7216107B & Fair & Female & Clipped & 79.0 & 3.47 & 4/24/2013 & 695 \\
\hline LGR & 3D9.1C2DDBA102 & G72097637 & Good & Female & Intact & 73.0 & 2.69 & $4 / 25 / 2013$ & 695 \\
\hline LGR & 3D9.1C2DDBA813 & G72181865 & Good & Male & Intact & 61.0 & 1.82 & 4/25/2013 & 695 \\
\hline LGR & 3D9.1C2D48629A & G7208CE03 & Fair & Male & Intact & 58.0 & 1.46 & 4/26/2013 & 695 \\
\hline LGR & 3D9.1C2D4899A3 & G72124C38 & Good & Female & Intact & 58.0 & 1.32 & 4/26/2013 & 695 \\
\hline LGR & 3D9.1C2DDBCA49 & G72164342 & Fair & Female & Intact & 71.0 & 2.33 & $4 / 26 / 2013$ & 695 \\
\hline LGR & 3D9.1C2DE8CB2D & G7218761F & Fair & Female & Clipped & 68.0 & 2.23 & 4/26/2013 & 695 \\
\hline LGR & 3D9.1C2DDBDBE3 & G7210B39C & Fair & Female & Clipped & 78.0 & 3.75 & 4/27/2013 & 695 \\
\hline LGR & 3D9.1C2DDC0176 & G72110FC9 & Good & Female & Clipped & 53.0 & 1.03 & 4/27/2013 & 695 \\
\hline LGR & 3D9.1C2DDBBEDD & G7215FF86 & Good & Male & Intact & 59.0 & 1.67 & 4/28/2013 & 695 \\
\hline LGR & 3D9.1C2DDC1E40 & G72114613 & Fair & Female & Clipped & 71.0 & 2.57 & $4 / 28 / 2013$ & 695 \\
\hline LGR & 3D9.1C2DDBA2FC & G72176F06 & Fair & Female & Clipped & 77.0 & 3.36 & 4/28/2013 & 695 \\
\hline LGR & 3D9.1C2DDBF7CB & G721811F9 & Fair & Female & Clipped & 69.0 & 2.68 & 4/28/2013 & 695 \\
\hline
\end{tabular}


Table B.1. (contd)

\begin{tabular}{|c|c|c|c|c|c|c|c|c|c|}
\hline $\begin{array}{l}\text { Tagging } \\
\text { Site }\end{array}$ & PIT Tag \# & JSATS Tag \# & $\begin{array}{l}\text { Condition } \\
\text { (Good/Fair) }\end{array}$ & $\begin{array}{c}\text { Sex } \\
\text { (Male/Female) }\end{array}$ & $\begin{array}{c}\text { Adipose Fin } \\
\text { (Intact/Clipped) }\end{array}$ & $\begin{array}{l}\text { Length } \\
\text { (cm) }\end{array}$ & $\begin{array}{l}\text { Weight } \\
\text { (kg) }\end{array}$ & Release Date & $\begin{array}{c}\text { Release } \\
\text { rkm }\end{array}$ \\
\hline LGR & 3D9.1C2D483BDC & G72094896 & Fair & Female & Intact & 70.0 & 2.37 & $4 / 29 / 2013$ & 695 \\
\hline LGR & 3D9.1C2DDB98AB & G722A4ABE & Good & Male & Intact & 64.0 & 1.97 & $4 / 29 / 2013$ & 695 \\
\hline LGR & 3D9.1C2DDBF3D0 & G722A5680 & Good & Male & Intact & 69.0 & 2.35 & $4 / 29 / 2013$ & 695 \\
\hline LGR & 3D9.1C2DE21D6E & G720F57E0 & Good & Female & Clipped & 77.0 & 3.22 & $4 / 29 / 2013$ & 695 \\
\hline LGR & 3D9.1C2DDBE543 & G720FD30D & Good & Female & Clipped & 68.0 & 2.13 & 4/29/2013 & 695 \\
\hline LGR & 3D9.1C2DDC226F & G7212B632 & Fair & Female & Clipped & 69.0 & 2.17 & 4/29/2013 & 695 \\
\hline LGR & 3D9.1C2DDC1E93 & G7212E455 & Good & Female & Intact & 55.0 & 1.14 & $4 / 30 / 2013$ & 695 \\
\hline LGR & 3D9.1C2DDBD953 & G722A13F9 & Good & Female & Intact & 59.0 & 1.34 & 4/30/2013 & 695 \\
\hline LGR & 3D9.1C2DDBB303 & G72097828 & Good & Female & Clipped & 55.0 & 1.19 & $4 / 30 / 2013$ & 695 \\
\hline LGR & 3D9.1C2DDC2278 & G720AEB8E & Good & Female & Clipped & 78.0 & 3.67 & $4 / 30 / 2013$ & 695 \\
\hline LGR & 3D9.1C2DE1D035 & G72094F15 & Good & Female & Intact & 58.0 & 1.52 & $5 / 1 / 2013$ & 695 \\
\hline LGR & 3D9.1C2D4775DC & G720A4460 & Fair & Female & Intact & 74.0 & 2.68 & $5 / 1 / 2013$ & 695 \\
\hline LGR & 3D9.1C2DDBEBE7 & G72176119 & Fair & Female & Intact & 84.0 & 4.07 & $5 / 1 / 2013$ & 695 \\
\hline LGR & 3D9.1C2DDBF31C & G72178932 & Good & Female & Intact & 55.0 & 1.24 & $5 / 1 / 2013$ & 695 \\
\hline LGR & 3D9.1C2DDC135E & G7217950C & Fair & Male & Intact & 62.0 & 1.66 & $5 / 1 / 2013$ & 695 \\
\hline LGR & 3D9.1C2DDBE578 & G7217E616 & Good & Male & Intact & 65.0 & 2.18 & $5 / 1 / 2013$ & 695 \\
\hline LGR & 3D9.1C2DDBE349 & G72089F86 & Good & Female & Clipped & 61.0 & 1.55 & $5 / 1 / 2013$ & 695 \\
\hline LGR & 3D9.1C2DDBEA30 & G720FF270 & Good & Female & Clipped & 65.0 & 2.06 & $5 / 1 / 2013$ & 695 \\
\hline LGR & 3D9.1C2DDBCF4D & G72101C72 & Good & Female & Clipped & 67.0 & 2.27 & $5 / 1 / 2013$ & 695 \\
\hline LGR & 3D9.1C2DE1B4C0 & G72109E42 & Fair & Female & Clipped & 80.0 & 3.39 & $5 / 1 / 2013$ & 695 \\
\hline LGR & 3D9.1C2DDC18E0 & G7211FD01 & Good & Female & Clipped & 68.0 & 2.27 & $5 / 1 / 2013$ & 695 \\
\hline LGR & 3D9.1C2DDB91A2 & G720A42BD & Fair & Female & Intact & 56.0 & 1.26 & $5 / 2 / 2013$ & 695 \\
\hline LGR & 3D9.1C2DB1B19E & G720EC874 & Fair & Female & Intact & 76.0 & 3.06 & $5 / 2 / 2013$ & 695 \\
\hline LGR & 3D9.1C2DE1FBA9 & G72111989 & Good & Male & Intact & 59.0 & 1.51 & $5 / 2 / 2013$ & 695 \\
\hline LGR & 3D9.1C2DDB9256 & G7211C57D & Fair & Male & Intact & 55.0 & 1.32 & $5 / 2 / 2013$ & 695 \\
\hline LGR & 3D9.1C2DDC016B & G72084372 & Good & Female & Clipped & 58.0 & 1.64 & $5 / 2 / 2013$ & 695 \\
\hline LGR & 3D9.1C2DDC02C7 & G720B13FC & Good & Female & Clipped & 67.0 & 2.26 & $5 / 2 / 2013$ & 695 \\
\hline LGR & 3D9.1C2DE19D44 & G721232DF & Good & Female & Clipped & 59.0 & 1.50 & $5 / 2 / 2013$ & 695 \\
\hline LGR & 3D9.1C2DDC17B8 & G7212A7F1 & Fair & Female & Clipped & 80.0 & 3.73 & $5 / 2 / 2013$ & 695 \\
\hline LGR & 3D9.1C2DDBEA63 & G7217BF51 & Fair & Female & Clipped & 71.0 & 2.63 & $5 / 2 / 2013$ & 695 \\
\hline
\end{tabular}


Table B.1. (contd)

\begin{tabular}{|c|c|c|c|c|c|c|c|c|c|}
\hline $\begin{array}{l}\text { Tagging } \\
\text { Site }\end{array}$ & PIT Tag \# & JSATS Tag \# & $\begin{array}{l}\text { Condition } \\
\text { (Good/Fair) }\end{array}$ & $\begin{array}{c}\text { Sex } \\
\text { (Male/Female) }\end{array}$ & $\begin{array}{c}\text { Adipose Fin } \\
\text { (Intact/Clipped) }\end{array}$ & $\begin{array}{l}\text { Length } \\
(\mathrm{cm})\end{array}$ & $\begin{array}{l}\text { Weight } \\
\text { (kg) }\end{array}$ & Release Date & $\begin{array}{c}\text { Release } \\
\text { rkm }\end{array}$ \\
\hline LGR & 3D9.1C2DDBA2CC & G720F7A3E & Good & Male & Intact & 76.0 & 2.94 & $5 / 3 / 2013$ & 695 \\
\hline LGR & 3D9.1C2DDC00C7 & G7229A7FF & Good & Female & Intact & 58.0 & 1.36 & $5 / 3 / 2013$ & 695 \\
\hline LGR & 3D9.1C2DDC0F14 & G7208E7BC & Good & Female & Clipped & 56.0 & 1.12 & $5 / 3 / 2013$ & 695 \\
\hline LGR & 3D9.1C2DDC064B & G720942E8 & Good & Female & Clipped & 74.0 & 2.63 & $5 / 3 / 2013$ & 695 \\
\hline LGR & 3D9.1C2DDBF335 & G720A0E58 & Fair & Female & Clipped & 68.0 & 2.17 & $5 / 3 / 2013$ & 695 \\
\hline LGR & 3D9.1C2DDC04A1 & G720AE0AE & Good & Female & Clipped & 55.0 & 1.12 & $5 / 3 / 2013$ & 695 \\
\hline LGR & 3D9.1C2DDBBA31 & G721213A2 & Good & Female & Clipped & 63.0 & 1.78 & $5 / 3 / 2013$ & 695 \\
\hline LGR & 3D9.1C2DDBB2B2 & G721454CD & Good & Female & Clipped & 81.0 & 3.34 & $5 / 3 / 2013$ & 695 \\
\hline LGR & 3D9.1C2DDBDBCB & G72120183 & Good & Female & Intact & 62.0 & 1.75 & $5 / 4 / 2013$ & 695 \\
\hline LGR & 3D9.1C2DCE95F7 & G72178212 & Good & Female & Intact & 66.0 & 1.81 & $5 / 4 / 2013$ & 695 \\
\hline LGR & 3D9.1C2DDBDBE1 & G7217CA96 & Good & Male & Intact & 58.0 & 1.30 & $5 / 4 / 2013$ & 695 \\
\hline LGR & 3D9.1C2DDBBFAB & G721238A1 & Good & Female & Clipped & 58.0 & 1.15 & $5 / 4 / 2013$ & 695 \\
\hline LGR & 3D9.1C2DDB986B & G721678DC & Good & Female & Clipped & 71.0 & 2.37 & $5 / 4 / 2013$ & 695 \\
\hline LGR & 3D9.1C2DDBE6EB & G720837EB & Good & Female & Intact & 64.0 & 1.56 & $5 / 5 / 2013$ & 695 \\
\hline LGR & 3D9.1C2DE1C219 & G720F7CE3 & Good & Female & Clipped & 66.0 & 2.25 & $5 / 5 / 2013$ & 695 \\
\hline LGR & 3D9.1C2DE213A0 & G7210D8D9 & Fair & Female & Clipped & 84.0 & 4.30 & $5 / 5 / 2013$ & 695 \\
\hline LGR & 3D9.1C2DDBF3DD & G72130F58 & Fair & Female & Clipped & 55.0 & 1.22 & $5 / 5 / 2013$ & 695 \\
\hline LGR & 3D9.1C2DDBA4D2 & G720929AD & Good & Female & Intact & 60.0 & 1.70 & 5/6/2013 & 695 \\
\hline LGR & 3D9.1C2DDBD5AD & G7211C423 & Good & Female & Intact & 59.0 & 1.40 & 5/6/2013 & 695 \\
\hline LGR & 3D9.1C2DB08DA4 & G7213D88C & Good & Female & Intact & 73.0 & 2.60 & 5/6/2013 & 695 \\
\hline LGR & 3D9.1C2DDB9B50 & G7214A33A & Good & Female & Clipped & 65.0 & 2.00 & $5 / 6 / 2013$ & 695 \\
\hline LGR & 3D9.1C2DDB9164 & G722A3F79 & Fair & Female & Clipped & 69.0 & 2.18 & 5/6/2013 & 695 \\
\hline LGR & 3D9.1C2DDC0F98 & G7208AF38 & Good & Female & Intact & 56.0 & 1.31 & $5 / 7 / 2013$ & 695 \\
\hline LGR & 3D9.1C2DE20760 & G7208B1BA & Fair & Female & Intact & 75.0 & 2.85 & $5 / 7 / 2013$ & 695 \\
\hline LGR & 3D9.1C2DD5CECA & G720A8BEB & Good & Male & Intact & 77.0 & 3.47 & $5 / 7 / 2013$ & 695 \\
\hline LGR & 3D9.1C2DDBBBE3 & G72161125 & Good & Male & Intact & 61.0 & 1.61 & 5/7/2013 & 695 \\
\hline LGR & 3D9.1C2DDC10BB & G722A4EDF & Good & Female & Intact & 57.0 & 1.16 & $5 / 7 / 2013$ & 695 \\
\hline LGR & 3D9.1C2DDBA39A & G720B4807 & Fair & Female & Clipped & 80.0 & 2.67 & $5 / 7 / 2013$ & 695 \\
\hline LGR & 3D9.1C2DDC0177 & G720FA528 & Fair & Male & Clipped & 55.0 & 1.21 & $5 / 7 / 2013$ & 695 \\
\hline LGR & 3D9.1C2DDBA62D & G7210EADB & Good & Male & Clipped & 49.0 & 0.96 & $5 / 7 / 2013$ & 695 \\
\hline
\end{tabular}


Table B.1. (contd)

\begin{tabular}{|c|c|c|c|c|c|c|c|c|c|}
\hline $\begin{array}{l}\text { Tagging } \\
\text { Site }\end{array}$ & PIT Tag \# & JSATS Tag \# & $\begin{array}{l}\text { Condition } \\
\text { (Good/Fair) }\end{array}$ & $\begin{array}{c}\text { Sex } \\
\text { (Male/Female) }\end{array}$ & $\begin{array}{c}\text { Adipose Fin } \\
\text { (Intact/Clipped) }\end{array}$ & $\begin{array}{l}\text { Length } \\
\text { (cm) }\end{array}$ & $\begin{array}{l}\text { Weight } \\
\text { (kg) }\end{array}$ & Release Date & $\begin{array}{c}\text { Release } \\
\text { rkm }\end{array}$ \\
\hline LGR & 3D9.1C2DE1FB22 & G7211036A & Fair & Male & Clipped & 61.0 & 1.92 & $5 / 7 / 2013$ & 695 \\
\hline LGR & 3D9.1C2DDBD75A & G72136A02 & Good & Female & Clipped & 52.0 & 0.82 & $5 / 7 / 2013$ & 695 \\
\hline LGR & 3D9.1C2DDB92E9 & G72159340 & Good & Female & Clipped & 66.0 & 2.09 & $5 / 7 / 2013$ & 695 \\
\hline LGR & 3D9.1C2DDBCF38 & G72160C45 & Good & Female & Clipped & 74.0 & 2.95 & $5 / 7 / 2013$ & 695 \\
\hline LGR & 3D9.1C2DDBBD44 & G7217669A & Good & Female & Clipped & 68.0 & 2.29 & $5 / 7 / 2013$ & 695 \\
\hline LGR & 3D9.1C2DDBB4D2 & G7229C019 & Good & Female & Clipped & 55.0 & 1.08 & $5 / 7 / 2013$ & 695 \\
\hline LGR & 3D9.1C2DDC20FD & G72089805 & Good & Male & Intact & 57.0 & 1.30 & $5 / 8 / 2013$ & 695 \\
\hline LGR & 3D9.1C2DDBDD9F & G7208E6E2 & Fair & Male & Intact & 54.0 & 1.22 & $5 / 8 / 2013$ & 695 \\
\hline LGR & 3D9.1C2DAC409C & G720A2A1A & Good & Female & Intact & 66.0 & 2.00 & $5 / 8 / 2013$ & 695 \\
\hline LGR & 3D9.1C2DB1AA5C & G7211DF9E & Good & Female & Intact & 55.0 & 1.27 & $5 / 8 / 2013$ & 695 \\
\hline LGR & 3D9.1C2DAC5999 & G72124D66 & Good & Male & Intact & 58.0 & 1.54 & $5 / 8 / 2013$ & 695 \\
\hline LGR & 3D9.1C2DDC25D3 & G7213FF2C & Good & Female & Intact & 58.0 & 1.54 & 5/8/2013 & 695 \\
\hline LGR & 3D9.1C2DDC18C3 & G7217A5B2 & Good & Female & Intact & 65.0 & 1.65 & $5 / 8 / 2013$ & 695 \\
\hline LGR & 3D9.1C2DDC146B & G72085991 & Good & Female & Clipped & 59.0 & 1.34 & 5/8/2013 & 695 \\
\hline LGR & 3D9.1C2DDC1D53 & G72088F1B & Good & Female & Clipped & 53.0 & 0.94 & $5 / 8 / 2013$ & 695 \\
\hline LGR & 3D9.1C2DE21F88 & G720895F8 & Good & Female & Clipped & 56.0 & 1.28 & $5 / 8 / 2013$ & 695 \\
\hline LGR & 3D9.1C2D7C976A & G7208F340 & Good & Female & Clipped & 60.0 & 1.71 & $5 / 8 / 2013$ & 695 \\
\hline LGR & 3D9.1C2DE1DD6A & G720ED514 & Good & Female & Clipped & 52.0 & 1.03 & $5 / 8 / 2013$ & 695 \\
\hline LGR & 3D9.1C2DDB9ACA & G7211754F & Good & Female & Clipped & 57.0 & 1.26 & $5 / 8 / 2013$ & 695 \\
\hline LGR & 3D9.1C2DDC180F & G72175A87 & Good & Female & Clipped & 54.0 & 1.12 & $5 / 8 / 2013$ & 695 \\
\hline LGR & 3D9.1C2DDBB203 & G72087B0E & Good & Female & Intact & 71.0 & 2.89 & $5 / 9 / 2013$ & 695 \\
\hline LGR & 3D9.1C2DDC1793 & G720889C6 & Good & Female & Intact & 54.0 & 1.02 & $5 / 9 / 2013$ & 695 \\
\hline LGR & 3D9.1C2D482A1C & G72109562 & Good & Male & Intact & 57.0 & 1.45 & $5 / 9 / 2013$ & 695 \\
\hline LGR & 3D9.1C2DDBE97F & G721245A4 & Good & Female & Intact & 59.0 & 1.52 & $5 / 9 / 2013$ & 695 \\
\hline LGR & 3D9.1C2DDBC9E5 & G7213C750 & Good & Female & Intact & 64.0 & 1.96 & $5 / 9 / 2013$ & 695 \\
\hline LGR & 3D9.1C2DDB99E5 & G7217CD15 & Good & Female & Intact & 63.0 & 1.79 & $5 / 9 / 2013$ & 695 \\
\hline LGR & 3D9.1C2DDBEC6C & G7210943C & Good & Female & Clipped & 74.0 & 2.85 & $5 / 9 / 2013$ & 695 \\
\hline LGR & 3D9.1C2DDBCF17 & G7210AEFC & Fair & Female & Clipped & 69.0 & 2.11 & $5 / 9 / 2013$ & 695 \\
\hline LGR & 3D9.1C2DDC1BD3 & G7211E383 & Good & Female & Clipped & 72.0 & 2.90 & 5/9/2013 & 695 \\
\hline LGR & 3D9.1C2DDBA2DC & G7213BDD6 & Good & Male & Clipped & 58.0 & 1.34 & $5 / 9 / 2013$ & 695 \\
\hline
\end{tabular}


Table B.1. (contd)

\begin{tabular}{|c|c|c|c|c|c|c|c|c|c|}
\hline $\begin{array}{l}\text { Tagging } \\
\text { Site }\end{array}$ & PIT Tag \# & JSATS Tag \# & $\begin{array}{l}\text { Condition } \\
\text { (Good/Fair) }\end{array}$ & $\begin{array}{c}\text { Sex } \\
\text { (Male/Female) }\end{array}$ & $\begin{array}{c}\text { Adipose Fin } \\
\text { (Intact/Clipped) }\end{array}$ & $\begin{array}{l}\text { Length } \\
\text { (cm) }\end{array}$ & $\begin{array}{l}\text { Weight } \\
\text { (kg) }\end{array}$ & Release Date & $\begin{array}{c}\text { Release } \\
\text { rkm }\end{array}$ \\
\hline LGR & 3D9.1C2DDBAF10 & G7214A75B & Good & Female & Clipped & 59.0 & 1.53 & $5 / 9 / 2013$ & 695 \\
\hline LGR & 3D9.1C2DDC04ED & G72159721 & Good & Male & Clipped & 63.0 & 1.61 & $5 / 9 / 2013$ & 695 \\
\hline LGR & 3D9.1C2DDBE9DF & G7215BAFF & Good & Female & Clipped & 72.0 & 3.06 & 5/9/2013 & 695 \\
\hline LGR & 3D9.1C2DDBE51C & G7215F325 & Good & Male & Clipped & 59.0 & 1.62 & $5 / 9 / 2013$ & 695 \\
\hline LGR & 3D9.1C2DE1D103 & G72099B23 & Good & Male & Intact & 57.0 & 1.23 & $5 / 10 / 2013$ & 695 \\
\hline LGR & 3D9.1C2DE20743 & G720B741A & Good & Male & Intact & 58.0 & 1.44 & $5 / 10 / 2013$ & 695 \\
\hline LGR & 3D9.1C2DDBE87D & G7210D3F9 & Good & Male & Intact & 61.0 & 1.39 & $5 / 10 / 2013$ & 695 \\
\hline LGR & 3D9.1C2DDBF86F & G7213EC53 & Fair & Female & Intact & 64.0 & 1.75 & $5 / 10 / 2013$ & 695 \\
\hline LGR & 3D9.1C2DDBB558 & G72162618 & Good & Female & Intact & 63.0 & 1.75 & $5 / 10 / 2013$ & 695 \\
\hline LGR & 3D9.1C2DDC1412 & G72163F19 & Good & Female & Intact & 68.0 & 2.55 & $5 / 10 / 2013$ & 695 \\
\hline LGR & 3D9.1C2DDBD8E4 & G72086B93 & Good & Female & Clipped & 58.0 & 1.29 & $5 / 10 / 2013$ & 695 \\
\hline LGR & 3D9.1C2DDB9282 & G7208C2A0 & Good & Female & Clipped & 55.0 & 1.24 & $5 / 10 / 2013$ & 695 \\
\hline LGR & 3D9.1C2DE1C3E9 & G72095C6A & Fair & Male & Clipped & 58.0 & 1.30 & $5 / 10 / 2013$ & 695 \\
\hline LGR & 3D9.1C2DDBC0D1 & G721035CD & Fair & Female & Clipped & 74.0 & 3.08 & $5 / 10 / 2013$ & 695 \\
\hline LGR & 3D9.1C2DDC1210 & G7211F49D & Good & Female & Clipped & 55.0 & 1.13 & $5 / 10 / 2013$ & 695 \\
\hline LGR & 3D9.1C2DDBAEE8 & G72140CD4 & Good & Female & Clipped & 67.0 & 1.98 & $5 / 10 / 2013$ & 695 \\
\hline LGR & 3D9.1C2DDB9481 & G72143F88 & Good & Female & Clipped & 67.0 & 2.33 & $5 / 10 / 2013$ & 695 \\
\hline LGR & 3D9.1C2DDBBE77 & G721536D0 & Good & Female & Clipped & 69.0 & 2.17 & $5 / 10 / 2013$ & 695 \\
\hline LGR & 3D9.1C2DDBB1AE & G721742D8 & Good & Female & Clipped & 67.0 & 1.87 & $5 / 10 / 2013$ & 695 \\
\hline LGR & 3D9.1C2DDC27C4 & G7229D659 & Good & Female & Clipped & 67.0 & 2.25 & $5 / 10 / 2013$ & 695 \\
\hline LGR & 3D9.1C2DE1EDD8 & G722A0BA6 & Fair & Female & Clipped & 58.0 & 1.41 & $5 / 10 / 2013$ & 695 \\
\hline LGR & 3D9.1C2DDBB0AA & G722A53BF & Good & Female & Clipped & 56.0 & 1.27 & $5 / 10 / 2013$ & 695 \\
\hline LGR & 3D9.1C2DDBF5B3 & G72087170 & Good & Female & Intact & 57.0 & 1.40 & $5 / 11 / 2013$ & 695 \\
\hline LGR & 3D9.1C2DDBE77A & G72087E31 & Good & Female & Intact & 60.0 & 1.70 & $5 / 11 / 2013$ & 695 \\
\hline LGR & 3D9.1C2DDC172C & G72113509 & Good & Female & Intact & 59.0 & 1.43 & $5 / 11 / 2013$ & 695 \\
\hline LGR & 3D9.1C2DDC0E90 & G72114BEE & Good & Male & Intact & 56.0 & 1.29 & $5 / 11 / 2013$ & 695 \\
\hline LGR & 3D9.1C2DDC2355 & G72159D5F & Good & Male & Intact & 54.0 & 1.10 & $5 / 11 / 2013$ & 695 \\
\hline LGR & 3D9.1C2DDBD5F9 & G72176B67 & Good & Female & Intact & 61.0 & 1.60 & $5 / 11 / 2013$ & 695 \\
\hline LGR & 3D9.1C2DDBDB72 & G721798F1 & Fair & Female & Intact & 63.0 & 1.61 & $5 / 11 / 2013$ & 695 \\
\hline LGR & 3D9.1C2DDC2354 & G722A4C63 & Good & Female & Intact & 64.0 & 1.83 & $5 / 11 / 2013$ & 695 \\
\hline
\end{tabular}


Table B.1. (contd)

\begin{tabular}{|c|c|c|c|c|c|c|c|c|c|}
\hline $\begin{array}{l}\text { Tagging } \\
\text { Site }\end{array}$ & PIT Tag \# & JSATS Tag \# & $\begin{array}{l}\text { Condition } \\
\text { (Good/Fair) }\end{array}$ & $\begin{array}{c}\text { Sex } \\
\text { (Male/Female) } \\
\end{array}$ & $\begin{array}{c}\text { Adipose Fin } \\
\text { (Intact/Clipped) }\end{array}$ & $\begin{array}{l}\text { Length } \\
(\mathrm{cm})\end{array}$ & $\begin{array}{c}\text { Weight } \\
(\mathrm{kg})\end{array}$ & Release Date & $\begin{array}{c}\text { Release } \\
\text { rkm }\end{array}$ \\
\hline$\overline{L G R}$ & 3D9.1C2DCE3D57 & G7208BA9A & Fair & Female & Clipped & 62.0 & 1.76 & $5 / 11 / 2013$ & 695 \\
\hline LGR & 3D9.1C2DDBA424 & G72091BAF & Good & Female & Clipped & 68.0 & 2.25 & $5 / 11 / 2013$ & 695 \\
\hline LGR & 3D9.1C2DDBBFE7 & G72095275 & Good & Female & Clipped & 65.0 & 2.34 & $5 / 11 / 2013$ & 695 \\
\hline LGR & 3D9.1C2DDBF362 & G7210CAF8 & Good & Male & Clipped & 54.0 & 1.10 & $5 / 11 / 2013$ & 695 \\
\hline LGR & 3D9.1C2DDB9231 & G7211D181 & Good & Male & Clipped & 55.0 & 1.20 & $5 / 11 / 2013$ & 695 \\
\hline LGR & 3D9.1C2DDBCCE5 & G7212B48E & Fair & Female & Clipped & 57.0 & 1.43 & $5 / 11 / 2013$ & 695 \\
\hline LGR & 3D9.1C2DDBE337 & G7213B02B & Fair & Male & Clipped & 56.0 & 1.36 & $5 / 11 / 2013$ & 695 \\
\hline LGR & 3D9.1C2DDC1AE6 & G721541AB & Good & Female & Clipped & 65.0 & 2.00 & $5 / 11 / 2013$ & 695 \\
\hline LGR & 3D9.1C2DDBA8DB & G722A7B5E & Good & Female & Clipped & 54.0 & 1.09 & $5 / 11 / 2013$ & 695 \\
\hline LGR & 3D9.1C2DDBD92B & G720F0B98 & Good & Male & Intact & 54.0 & 1.25 & $5 / 12 / 2013$ & 695 \\
\hline LGR & 3D9.1C2DDB91C7 & G72105D6A & Fair & Female & Intact & 58.0 & 1.34 & $5 / 12 / 2013$ & 695 \\
\hline LGR & 3D9.1C2DDBAF42 & G72086351 & Good & Female & Clipped & 53.0 & 1.18 & $5 / 12 / 2013$ & 695 \\
\hline LGR & 3D9.1C2DE1DE7D & G720FC6AF & Good & Male & Clipped & 55.0 & 1.16 & $5 / 12 / 2013$ & 695 \\
\hline LGR & 3D9.1C2DDBF844 & G721093BF & Good & Male & Clipped & 54.0 & 1.13 & $5 / 12 / 2013$ & 695 \\
\hline LGR & 3D9.1C2DDBE52C & G7210A482 & Good & Female & Clipped & 69.0 & 2.58 & $5 / 12 / 2013$ & 695 \\
\hline LGR & 3D9.1C2DDC207F & G7215D0E4 & Fair & Male & Clipped & 58.0 & 1.53 & $5 / 12 / 2013$ & 695 \\
\hline LGR & 3D9.1C2DDBC0E8 & G72163106 & Good & Female & Clipped & 62.0 & 1.81 & $5 / 12 / 2013$ & 695 \\
\hline LGR & 3D9.1C2DDC0841 & G7217A911 & Good & Female & Clipped & 63.0 & 1.68 & $5 / 12 / 2013$ & 695 \\
\hline LGR & 3D9.1C2DDB90FD & G7208B767 & Fair & Female & Intact & 58.0 & 1.36 & $5 / 13 / 2013$ & 695 \\
\hline LGR & 3D9.1C2DDBB345 & G720F2379 & Good & Male & Intact & 51.0 & 1.12 & $5 / 13 / 2013$ & 695 \\
\hline LGR & 3D9.1C2DE1ED4D & G7211A8E5 & Fair & Female & Intact & 55.0 & 1.25 & $5 / 13 / 2013$ & 695 \\
\hline LGR & 3D9.1C2DDBDC10 & G7212033F & Good & Female & Intact & 66.0 & 1.94 & $5 / 13 / 2013$ & 695 \\
\hline LGR & 3D9.1C2DDBCA3D & G72158E20 & Good & Female & Intact & 60.0 & 1.58 & $5 / 13 / 2013$ & 695 \\
\hline LGR & 3D9.1C2DB6F7AA & G721751A7 & Good & Male & Intact & 55.0 & 1.34 & $5 / 13 / 2013$ & 695 \\
\hline LGR & 3D9.1C2DDBD8EC & G72182CBA & Good & Female & Intact & 64.0 & 1.96 & $5 / 13 / 2013$ & 695 \\
\hline LGR & 3D9.1C2DE20738 & G72183084 & Fair & Male & Intact & 56.0 & 1.43 & $5 / 13 / 2013$ & 695 \\
\hline LGR & 3D9.1C2DDBE83F & G72083557 & Good & Female & Clipped & 54.0 & 1.14 & $5 / 13 / 2013$ & 695 \\
\hline LGR & 3D9.1C2DDBCA5D & G720A48C3 & Fair & Male & Clipped & 60.0 & 1.54 & $5 / 13 / 2013$ & 695 \\
\hline LGR & 384.1B796EF371 & G7210DA65 & Good & Female & Clipped & 53.0 & 1.13 & $5 / 13 / 2013$ & 695 \\
\hline LGR & 3D9.1C2DDBF099 & G7215A79F & Good & Female & Clipped & 74.0 & 2.97 & $5 / 13 / 2013$ & 695 \\
\hline
\end{tabular}


Table B.1. (contd)

\begin{tabular}{|c|c|c|c|c|c|c|c|c|c|}
\hline $\begin{array}{l}\text { Tagging } \\
\text { Site }\end{array}$ & PIT Tag \# & JSATS Tag \# & $\begin{array}{l}\text { Condition } \\
\text { (Good/Fair) }\end{array}$ & $\begin{array}{c}\text { Sex } \\
\text { (Male/Female) } \\
\end{array}$ & $\begin{array}{c}\text { Adipose Fin } \\
\text { (Intact/Clipped) }\end{array}$ & $\begin{array}{l}\text { Length } \\
(\mathrm{cm})\end{array}$ & $\begin{array}{c}\text { Weight } \\
(\mathrm{kg})\end{array}$ & Release Date & $\begin{array}{c}\text { Release } \\
\text { rkm }\end{array}$ \\
\hline$\overline{L G R}$ & 3D9.1C2DDC23BC & G72299741 & Good & Female & Clipped & 58.0 & 1.70 & $5 / 13 / 2013$ & 695 \\
\hline LGR & 3D9.1C2DDBE966 & G720A331B & Fair & Male & Intact & 54.0 & 1.28 & $5 / 14 / 2013$ & 695 \\
\hline LGR & 3D9.1C2DDC11BF & G720A55A3 & Good & Male & Intact & 58.0 & 1.58 & $5 / 14 / 2013$ & 695 \\
\hline LGR & 3D9.1C2DDBC3AA & G720B6D1B & Good & Female & Intact & 60.0 & 1.52 & $5 / 14 / 2013$ & 695 \\
\hline LGR & 3D9.1C2DE19529 & G72132505 & Good & Male & Intact & 66.0 & 2.20 & $5 / 14 / 2013$ & 695 \\
\hline LGR & 3D9.1C2DDBBC3E & G72165C9E & Good & Female & Intact & 55.0 & 1.31 & $5 / 14 / 2013$ & 695 \\
\hline LGR & 3D9.1C2DDC2649 & G72180DC7 & Good & Female & Intact & 61.0 & 1.71 & $5 / 14 / 2013$ & 695 \\
\hline LGR & 3D9.1C2DDBF7F8 & G7209B29C & Good & Female & Clipped & 67.0 & 2.01 & $5 / 14 / 2013$ & 695 \\
\hline LGR & 3D9.1C2DDBF7FF & G720A28A6 & Good & Female & Clipped & 59.0 & 1.52 & $5 / 14 / 2013$ & 695 \\
\hline LGR & 3D9.1C2DE1DD4C & G720A6C81 & Good & Male & Clipped & 56.0 & 1.49 & $5 / 14 / 2013$ & 695 \\
\hline LGR & 3D9.1C2DDBF885 & G7214B7C6 & Good & Male & Clipped & 56.0 & 1.40 & $5 / 14 / 2013$ & 695 \\
\hline LGR & 3D9.1C2DDC0E19 & G72185480 & Good & Female & Clipped & 58.0 & 1.45 & $5 / 14 / 2013$ & 695 \\
\hline LGR & 3D9.1C2DB2FE1D & G722A0FC7 & Good & Female & Clipped & 55.0 & 1.09 & $5 / 14 / 2013$ & 695 \\
\hline LGR & 3D9.1C2DDBD774 & G722A589F & Good & Female & Clipped & 56.0 & 1.40 & $5 / 14 / 2013$ & 695 \\
\hline LGR & 3D9.1C2DDBAD21 & G720887D9 & Good & Female & Intact & 55.0 & 1.19 & $5 / 15 / 2013$ & 695 \\
\hline LGR & 3D9.1C2DDBA27A & G720A2405 & Good & Female & Intact & 56.0 & 1.38 & $5 / 15 / 2013$ & 695 \\
\hline LGR & 3D9.1C2DDC05E3 & G720EC92A & Good & Male & Intact & 58.0 & 1.42 & $5 / 15 / 2013$ & 695 \\
\hline LGR & 3D9.1C2DAC6738 & G721029F3 & Good & Female & Intact & 61.0 & 1.61 & $5 / 15 / 2013$ & 695 \\
\hline LGR & 3D9.1C2DDBF846 & G72165DC0 & Good & Female & Intact & 57.0 & 1.52 & $5 / 15 / 2013$ & 695 \\
\hline LGR & 384.1B796D9BDF & G7217413A & Good & Male & Intact & 61.0 & 1.81 & $5 / 15 / 2013$ & 695 \\
\hline LGR & 3D9.1C2DE204C8 & G7218003A & Good & Male & Intact & 59.0 & 1.50 & $5 / 15 / 2013$ & 695 \\
\hline LGR & 3D9.1C2DDBF832 & G7229CF58 & Good & Female & Intact & 61.0 & 1.65 & $5 / 15 / 2013$ & 695 \\
\hline LGR & 3D9.1C2DE1C3B2 & G7209D887 & Good & Female & Clipped & 74.0 & 2.94 & $5 / 15 / 2013$ & 695 \\
\hline LGR & 3D9.1C2DDBB136 & G7215660B & Good & Female & Clipped & 60.0 & 1.74 & $5 / 15 / 2013$ & 695 \\
\hline LGR & 3D9.1C2DDC269A & G7217DE6A & Good & Female & Clipped & 68.0 & 2.40 & $5 / 15 / 2013$ & 695 \\
\hline LGR & 3D9.1C2DDBD73C & G720873CC & Good & Male & Intact & 73.0 & 2.54 & $5 / 16 / 2013$ & 695 \\
\hline LGR & 3D9.1C2DE1C120 & G72099780 & Good & Female & Intact & 56.0 & 1.30 & $5 / 16 / 2013$ & 695 \\
\hline LGR & 3D9.1C2DDBFA3B & G72108ABE & Good & Male & Intact & 68.0 & 2.17 & $5 / 16 / 2013$ & 695 \\
\hline LGR & 3D9.1C2DDC27BD & G7213D571 & Good & Female & Intact & 57.0 & 1.37 & $5 / 16 / 2013$ & 695 \\
\hline LGR & 3D9.1C2DDBA64A & G721410EA & Good & Male & Intact & 64.0 & 1.98 & $5 / 16 / 2013$ & 695 \\
\hline
\end{tabular}


Table B.1. (contd)

\begin{tabular}{|c|c|c|c|c|c|c|c|c|c|}
\hline $\begin{array}{l}\text { Tagging } \\
\text { Site }\end{array}$ & PIT Tag \# & JSATS Tag \# & $\begin{array}{l}\text { Condition } \\
\text { (Good/Fair) }\end{array}$ & $\begin{array}{c}\text { Sex } \\
\text { (Male/Female) }\end{array}$ & $\begin{array}{c}\text { Adipose Fin } \\
\text { (Intact/Clipped) }\end{array}$ & $\begin{array}{l}\text { Length } \\
(\mathrm{cm})\end{array}$ & $\begin{array}{l}\text { Weight } \\
\text { (kg) }\end{array}$ & Release Date & $\begin{array}{c}\text { Release } \\
\text { rkm }\end{array}$ \\
\hline LGR & 3D9.1C2DE1A814 & G7214450E & Fair & Female & Intact & 83.0 & 4.28 & $5 / 16 / 2013$ & 695 \\
\hline LGR & 3D9.1C2DDC1143 & G7217D8B7 & Good & Female & Intact & 68.0 & 2.18 & $5 / 16 / 2013$ & 695 \\
\hline LGR & 3D9.1C2DE1C4A1 & G7229A41D & Good & Female & Intact & 59.0 & 1.56 & $5 / 16 / 2013$ & 695 \\
\hline LGR & 3D9.1C2DDBE7CF & G7210A25F & Good & Female & Clipped & 61.0 & 1.63 & $5 / 16 / 2013$ & 695 \\
\hline LGR & 3D9.1C2DDC1AEC & G72112D56 & Good & Male & Clipped & 56.0 & 1.33 & $5 / 16 / 2013$ & 695 \\
\hline LGR & 3D9.1C2DDBCF1B & G7209A201 & Good & Female & Intact & 58.0 & 1.35 & $5 / 17 / 2013$ & 695 \\
\hline LGR & 3D9.1C2DDBB243 & G720B4ABB & Good & Female & Intact & 61.0 & 1.64 & $5 / 17 / 2013$ & 695 \\
\hline LGR & 3D9.1C2DB07C71 & G7210E4C4 & Good & Male & Intact & 54.0 & 1.18 & $5 / 17 / 2013$ & 695 \\
\hline LGR & 3D9.1C2DDBEC1F & G7213595E & Good & Female & Intact & 64.0 & 2.08 & $5 / 17 / 2013$ & 695 \\
\hline LGR & 3D9.1C2DB07C44 & G7214BCE6 & Good & Female & Intact & 57.0 & 1.34 & $5 / 17 / 2013$ & 695 \\
\hline LGR & 3D9.1C2DDBE7F4 & G722A3C9B & Good & Male & Intact & 57.0 & 1.43 & $5 / 17 / 2013$ & 695 \\
\hline LGR & 3D9.1C2DDC239E & G7208E03F & Good & Female & Clipped & 61.0 & 1.41 & $5 / 17 / 2013$ & 695 \\
\hline LGR & 3D9.1C2DDBA17E & G7215C418 & Fair & Male & Clipped & 56.0 & 1.31 & $5 / 17 / 2013$ & 695 \\
\hline LGR & 3D9.1C2DDBA2D9 & G722A800A & Good & Male & Clipped & 52.0 & 1.04 & $5 / 17 / 2013$ & 695 \\
\hline LGR & 3D9.1C2DDC070E & G7209C0D8 & Good & Female & Intact & 64.0 & 2.12 & $5 / 18 / 2013$ & 695 \\
\hline LGR & 3D9.1C2DDC00F4 & G720A4CA2 & Good & Male & Intact & 56.0 & 1.35 & $5 / 18 / 2013$ & 695 \\
\hline LGR & 3D9.1C2DDBAF02 & G72115432 & Good & Female & Intact & 67.0 & 2.01 & $5 / 18 / 2013$ & 695 \\
\hline LGR & 3D9.1C2DDBF1DB & G721471D1 & Good & Male & Intact & 63.0 & 1.95 & $5 / 18 / 2013$ & 695 \\
\hline LGR & 3D9.1C2DDBF3CD & G72161E64 & Good & Female & Intact & 67.0 & 2.33 & $5 / 18 / 2013$ & 695 \\
\hline LGR & 3D9.1C2DDBB146 & G7211FBDC & Good & Male & Intact & 57.0 & 1.40 & $5 / 20 / 2013$ & 695 \\
\hline LGR & 3D9.1C2DF79827 & G72134101 & Good & Female & Intact & 62.0 & 1.66 & $5 / 20 / 2013$ & 695 \\
\hline LGR & 3D9.1C2DDC191C & G7213AAC8 & Good & Female & Intact & 55.0 & 1.40 & $5 / 20 / 2013$ & 695 \\
\hline LGR & 3D9.1C2DDB9B49 & G7216840B & Good & Female & Intact & 54.0 & 1.17 & $5 / 20 / 2013$ & 695 \\
\hline LGR & 3D9.1C2DDC1323 & G7213DCED & Good & Female & Clipped & 68.0 & 2.15 & $5 / 20 / 2013$ & 695 \\
\hline LGR & 3D9.1C2DDC0E62 & G7213F2D1 & Fair & Female & Clipped & 74.0 & 2.91 & $5 / 20 / 2013$ & 695 \\
\hline LGR & 3D9.1C2DDBCF13 & G7214E643 & Good & Female & Clipped & 58.0 & 1.33 & $5 / 20 / 2013$ & 695 \\
\hline LGR & 3D9.1C2DDBCE77 & G7215DFA5 & Good & Male & Clipped & 60.0 & 1.46 & $5 / 20 / 2013$ & 695 \\
\hline LGR & 3D9.1C2DDC0DA6 & G7215FAB9 & Good & Male & Clipped & 60.0 & 1.48 & $5 / 20 / 2013$ & 695 \\
\hline LGR & 3D9.1C2DDBF3B0 & G7211CB62 & Good & Female & Intact & 65.0 & 1.94 & $5 / 21 / 2013$ & 695 \\
\hline LGR & 3D9.1C2DB06F31 & G72159FE3 & Good & Male & Intact & 56.0 & 1.25 & $5 / 21 / 2013$ & 695 \\
\hline
\end{tabular}


Table B.1. (contd)

\begin{tabular}{|c|c|c|c|c|c|c|c|c|c|}
\hline $\begin{array}{l}\text { Tagging } \\
\text { Site }\end{array}$ & PIT Tag \# & JSATS Tag \# & $\begin{array}{l}\text { Condition } \\
\text { (Good/Fair) }\end{array}$ & $\begin{array}{c}\text { Sex } \\
\text { (Male/Female) }\end{array}$ & $\begin{array}{c}\text { Adipose Fin } \\
\text { (Intact/Clipped) }\end{array}$ & $\begin{array}{l}\text { Length } \\
\text { (cm) }\end{array}$ & $\begin{array}{l}\text { Weight } \\
\text { (kg) }\end{array}$ & Release Date & $\begin{array}{c}\text { Release } \\
\text { rkm }\end{array}$ \\
\hline LGR & 3D9.1C2DDBCEF1 & G7215A980 & Good & Male & Intact & 71.0 & 2.23 & $5 / 21 / 2013$ & 695 \\
\hline LGR & 3D9.1C2DB0673F & G7215F27B & Good & Male & Intact & 56.0 & 1.27 & $5 / 21 / 2013$ & 695 \\
\hline LGR & 3D9.1C2DDBB048 & G72163E47 & Good & Female & Intact & 62.0 & 1.74 & $5 / 21 / 2013$ & 695 \\
\hline LGR & 3D9.1C2DDC0545 & G7212313D & Good & Female & Clipped & 68.0 & 2.47 & $5 / 21 / 2013$ & 695 \\
\hline LGR & 3D9.1C2DDBCC67 & G72141EF5 & Good & Female & Clipped & 69.0 & 2.41 & $5 / 21 / 2013$ & 695 \\
\hline LGR & 3D9.1C2DDBD8D7 & G721583DD & Good & Female & Clipped & 55.0 & 1.19 & $5 / 21 / 2013$ & 695 \\
\hline LGR & 3D9.1C2DDBFA84 & G72126C1B & Good & Female & Intact & 71.0 & 2.28 & $5 / 22 / 2013$ & 695 \\
\hline LGR & 3D9.1C2DDB9D80 & G7213B297 & Good & Male & Intact & 57.0 & 1.25 & $5 / 22 / 2013$ & 695 \\
\hline LGR & 3D9.1C2DDBE62D & G721409EB & Good & Female & Intact & 55.0 & 1.10 & $5 / 22 / 2013$ & 695 \\
\hline LGR & 3D9.1C2DDBCF7B & G7215222C & Good & Male & Intact & 70.0 & 2.12 & $5 / 22 / 2013$ & 695 \\
\hline LGR & 3D9.1C2DDBA4C1 & G7215CF38 & Good & Female & Intact & 70.0 & 2.20 & $5 / 22 / 2013$ & 695 \\
\hline LGR & 3D9.1C2DDBEA55 & G72145210 & Good & Male & Clipped & 56.0 & 1.32 & $5 / 22 / 2013$ & 695 \\
\hline LGR & 3D9.1C2DDC22E3 & G7215E898 & Good & Female & Clipped & 54.0 & 1.14 & $5 / 23 / 2013$ & 695 \\
\hline LGR & 3D9.1C2DDBA2ED & G7212277D & Good & Female & Clipped & 55.0 & 1.36 & $5 / 24 / 2013$ & 695 \\
\hline LGR & 3D9.1C2DDBA340 & G7212F86B & Good & Female & Clipped & 52.0 & 1.01 & $5 / 24 / 2013$ & 695 \\
\hline LGR & 3D9.1C2DDC239D & G721311DA & Good & Female & Clipped & 69.0 & 2.38 & $5 / 24 / 2013$ & 695 \\
\hline LGR & 3D9.1C2DDBF2EF & G72137D1C & Good & Female & Intact & 59.0 & 1.38 & $5 / 25 / 2013$ & 695 \\
\hline LGR & 3D9.1C2DDBFA71 & G72166AFD & Fair & Female & Intact & 69.0 & 2.48 & $5 / 25 / 2013$ & 695 \\
\hline LGR & 3D9.1C2DDC1D3E & G7212081F & Good & Female & Clipped & 57.0 & 1.19 & $5 / 25 / 2013$ & 695 \\
\hline LGR & 3D9.1C2DDBD573 & G72124718 & Fair & Female & Clipped & 60.0 & 1.39 & $5 / 25 / 2013$ & 695 \\
\hline LGR & 3D9.1C2DDC0DCD & G7212AB52 & Good & Female & Clipped & 65.0 & 1.81 & $5 / 25 / 2013$ & 695 \\
\hline LGR & 3D9.1C2DDB9A48 & G7211E13F & Good & Female & Intact & 60.0 & 1.47 & $5 / 26 / 2013$ & 695 \\
\hline LGR & 3D9.1C2DDC18E4 & G7212AF33 & Fair & Female & Intact & 75.0 & 3.45 & $5 / 26 / 2013$ & 695 \\
\hline LGR & 3D9.1C2DDBB2DB & G721429C8 & Fair & Female & Intact & 72.0 & 2.65 & $5 / 26 / 2013$ & 695 \\
\hline LGR & 3D9.1C2DAC61A1 & G72160D1B & Fair & Female & Intact & 73.0 & 2.54 & $5 / 26 / 2013$ & 695 \\
\hline LGR & 3D9.1C2DDBD205 & G72145AD2 & Good & Female & Clipped & 54.0 & 1.07 & $5 / 26 / 2013$ & 695 \\
\hline LGR & 3D9.1C2DDBB605 & G72148247 & Good & Female & Clipped & 66.0 & 2.06 & $5 / 26 / 2013$ & 695 \\
\hline LGR & 3D9.1C2DDBE542 & G72155E77 & Fair & Female & Clipped & 53.0 & 1.09 & $5 / 26 / 2013$ & 695 \\
\hline LGR & 3D9.1C2DDB918B & G721517AD & Good & Female & Intact & 71.0 & 2.35 & $5 / 27 / 2013$ & 695 \\
\hline LGR & 3D9.1C2DDB9A08 & G72157F0A & Good & Female & Clipped & 54.0 & 1.19 & $5 / 27 / 2013$ & 695 \\
\hline
\end{tabular}


Table B.1. (contd)

\begin{tabular}{|c|c|c|c|c|c|c|c|c|c|}
\hline $\begin{array}{l}\text { Tagging } \\
\text { Site }\end{array}$ & PIT Tag \# & JSATS Tag \# & $\begin{array}{l}\text { Condition } \\
\text { (Good/Fair) }\end{array}$ & $\begin{array}{c}\text { Sex } \\
\text { (Male/Female) }\end{array}$ & $\begin{array}{c}\text { Adipose Fin } \\
\text { (Intact/Clipped) }\end{array}$ & $\begin{array}{l}\text { Length } \\
(\mathrm{cm})\end{array}$ & $\begin{array}{l}\text { Weight } \\
\text { (kg) }\end{array}$ & Release Date & $\begin{array}{c}\text { Release } \\
\text { rkm }\end{array}$ \\
\hline LGR & 3D9.1C2DE21433 & G72131FC5 & Fair & Male & Intact & 57.0 & 1.43 & $5 / 28 / 2013$ & 695 \\
\hline LGR & 3D9.1C2DDBA3BF & G72166361 & Fair & Female & Intact & 57.0 & 1.49 & $5 / 28 / 2013$ & 695 \\
\hline LGR & 3D9.1C2DDC27EC & G7211C2FE & Fair & Male & Intact & 53.0 & 1.19 & $5 / 29 / 2013$ & 695 \\
\hline LGR & 3D9.1C2DDBFF4E & G72138C36 & Fair & Male & Intact & 54.0 & 1.08 & $5 / 29 / 2013$ & 695 \\
\hline LGR & 3D9.1C2DDB9453 & G72146E0D & Fair & Female & Intact & 70.0 & 2.31 & $5 / 29 / 2013$ & 695 \\
\hline LGR & 3D9.1C2DDBF655 & G7213D693 & Good & Female & Clipped & 73.0 & 3.40 & $5 / 29 / 2013$ & 695 \\
\hline LGR & 3D9.1C2DDBFF47 & G721616A6 & Good & Female & Clipped & 57.0 & 1.27 & $5 / 29 / 2013$ & 695 \\
\hline LGR & 3D9.1C2DDC269B & G72146B32 & Good & Female & Intact & 70.0 & 2.51 & $5 / 30 / 2013$ & 695 \\
\hline LGR & 3D9.1C2DDBA646 & G72166700 & Fair & Female & Intact & 58.0 & 1.54 & $5 / 30 / 2013$ & 695 \\
\hline LGR & 3D9.1C2DDB9BA0 & G72154969 & Good & Female & Clipped & 81.0 & 4.08 & 5/30/2013 & 695 \\
\hline LGR & 3D9.1C2DDC0E59 & G72137823 & Good & Female & Intact & 59.0 & 1.61 & $5 / 31 / 2013$ & 695 \\
\hline LGR & 3D9.1C2DDBF850 & G7214B57A & Good & Female & Intact & 58.0 & 1.49 & 5/31/2013 & 695 \\
\hline LGR & 3D9.1C2DB1AB87 & G7212D5B5 & Good & Female & Intact & 60.0 & 1.78 & 6/1/2013 & 695 \\
\hline LGR & 3D9.1C2DDBBD23 & G7213E0F0 & Good & Female & Intact & 71.0 & 2.54 & 6/1/2013 & 695 \\
\hline LGR & 3D9.1C2DDC139E & G7214A186 & Good & Male & Intact & 56.0 & 1.38 & $6 / 1 / 2013$ & 695 \\
\hline LGR & 3D9.1C2DDBBFB9 & G721618B9 & Good & Female & Intact & 68.0 & 2.30 & 6/1/2013 & 695 \\
\hline LGR & 3D9.1C2DDC0129 & G721498A4 & Fair & Female & Clipped & 55.0 & 1.19 & $6 / 1 / 2013$ & 695 \\
\hline LGR & 3D9.1C2DDBCE73 & G72134682 & Good & Female & Intact & 60.0 & 1.58 & 6/3/2013 & 695 \\
\hline LGR & 3D9.1C2DDBA5A7 & G7214DB00 & Good & Female & Intact & 64.0 & 1.89 & 6/3/2013 & 695 \\
\hline LGR & 3D9.1C2DDC0149 & G7214EC3D & Fair & Male & Intact & 55.0 & 1.14 & 6/3/2013 & 695 \\
\hline LGR & 3D9.1C2DDC0187 & G72124FDA & Good & Male & Clipped & 62.0 & 1.72 & 6/3/2013 & 695 \\
\hline LGR & 3D9.1C2DDBCE78 & G7212C8D5 & Good & Male & Clipped & 57.0 & 1.35 & 6/3/2013 & 695 \\
\hline LGR & 3D9.1C2DDBB267 & G7212974F & Good & Male & Intact & 57.0 & 1.70 & 6/5/2013 & 695 \\
\hline LGR & 3D9.1C2DDBCC58 & G72128430 & Good & Female & Clipped & 55.0 & 1.11 & 6/5/2013 & 695 \\
\hline LGR & 3D9.1C2DDBFF39 & G7214C660 & Good & Female & Intact & 58.0 & 1.42 & 6/6/2013 & 695 \\
\hline LGR & 3D9.1C2DDBA305 & G7215ACBF & Fair & Female & Intact & 64.0 & 1.76 & 6/6/2013 & 695 \\
\hline LGR & 3D9.1C2DDBC15F & G7212D848 & Fair & Female & Clipped & 59.0 & 1.38 & 6/6/2013 & 695 \\
\hline LGR & 3D9.1C2DDBB027 & G721355FD & Good & Male & Intact & 53.0 & 1.15 & 6/8/2013 & 695 \\
\hline LGR & 3D9.1C2DDBD998 & G7215A2A0 & Good & Female & Intact & 62.0 & 1.78 & 6/8/2013 & 695 \\
\hline LGR & 3D9.1C2DDBF64D & G72165E22 & Fair & Male & Clipped & 57.0 & 1.33 & 6/8/2013 & 695 \\
\hline
\end{tabular}


Table B.1. (contd)

\begin{tabular}{|c|c|c|c|c|c|c|c|c|c|}
\hline $\begin{array}{l}\text { Tagging } \\
\text { Site } \\
\end{array}$ & PIT Tag \# & JSATS Tag \# & $\begin{array}{l}\text { Condition } \\
\text { (Good/Fair) }\end{array}$ & $\begin{array}{c}\text { Sex } \\
\text { (Male/Female) } \\
\end{array}$ & $\begin{array}{c}\text { Adipose Fin } \\
\text { (Intact/Clipped) }\end{array}$ & $\begin{array}{l}\text { Length } \\
(\mathrm{cm})\end{array}$ & $\begin{array}{c}\text { Weight } \\
(\mathrm{kg})\end{array}$ & Release Date & $\begin{array}{c}\text { Release } \\
\text { rkm }\end{array}$ \\
\hline LGR & 3D9.1C2DDBF06E & G7214C87F & Good & Male & Intact & 58.0 & 1.31 & $6 / 9 / 2013$ & 695 \\
\hline LGR & 3D9.1C2DDC1123 & G7213B6F6 & Good & Male & Clipped & 57.0 & 1.44 & 6/9/2013 & 695 \\
\hline LGR & 3D9.1C2DDC1B6A & G7213C94F & Good & Female & Clipped & 54.0 & 1.12 & 6/9/2013 & 695 \\
\hline LGR & 3D9.1C2DDB968C & G72123D9E & Good & Male & Intact & 57.0 & 1.12 & 6/10/2013 & 695 \\
\hline LGR & 3D9.1C2DE21366 & G7212AA0C & Good & Male & Intact & 60.0 & 1.66 & $6 / 10 / 2013$ & 695 \\
\hline LGR & 3D9.1C2DE1DFAE & G721225C1 & Good & Male & Clipped & 60.0 & 1.53 & $6 / 10 / 2013$ & 695 \\
\hline LGR & 3D9.1C2DDBCF3A & G7211B926 & Good & Female & Intact & 57.0 & 1.57 & $6 / 11 / 2013$ & 695 \\
\hline LGR & 3D9.1C2DDBE8F3 & G72138648 & Fair & Male & Intact & 66.0 & 2.25 & $6 / 12 / 2013$ & 695 \\
\hline LGR & 3D9.1C2DDBDA17 & G721393EA & Good & Male & Intact & 65.0 & 2.10 & $6 / 13 / 2013$ & 695 \\
\hline LGR & 3D9.1C2DAC613B & G7213D9D2 & Good & Female & Intact & 64.0 & 1.86 & $6 / 14 / 2013$ & 695 \\
\hline LGR & 3D9.1C2DB30848 & G721572F7 & Fair & Male & Intact & 55.0 & 1.20 & $6 / 14 / 2013$ & 695 \\
\hline LGR & 3D9.1C2DDBB0F9 & G72157E54 & Good & Female & Intact & 76.0 & 3.04 & $6 / 14 / 2013$ & 695 \\
\hline LGR & 3D9.1C2DDBAF11 & G72141976 & Good & Male & Intact & 72.0 & 2.84 & $6 / 15 / 2013$ & 695 \\
\hline LGR & 3D9.1C2DDC21A4 & G72167CBD & Fair & Male & Clipped & 55.0 & 1.36 & $6 / 15 / 2013$ & 695 \\
\hline LGR & 3D9.1C2DDBE4D1 & G72162C66 & Fair & Male & Intact & 61.0 & 1.60 & $6 / 17 / 2013$ & 695 \\
\hline LGR & 3D9.1C2DDBCA5A & G72159B82 & Good & Male & Clipped & 60.0 & 1.57 & $6 / 17 / 2013$ & 695 \\
\hline LGR & 3D9.1C2DDBBE96 & G72161B5B & Good & Male & Clipped & 62.0 & 1.75 & $6 / 17 / 2013$ & 695 \\
\hline LGR & 3D9.1C2DDBA048 & G7215C7FA & Good & Female & Intact & 57.0 & 1.35 & 6/18/2013 & 695 \\
\hline ASO & 3D9.1C2E099C5F & G720AF033 & Good & Female & Intact & 67.2 & 2.58 & $4 / 11 / 2013$ & 761 \\
\hline ASO & 3D9.1C2DB071E1 & G7210EB85 & Fair & Female & Intact & 71.6 & 2.92 & $4 / 11 / 2013$ & 761 \\
\hline ASO & 3D9.1C2DCE33A7 & G72135BE2 & Good & Female & Intact & 68.9 & 2.40 & $4 / 11 / 2013$ & 761 \\
\hline ASO & 3D9.1C2DCE7311 & G7251BC82 & Fair & Male & Intact & 55.3 & 1.32 & $4 / 11 / 2013$ & 761 \\
\hline ASO & 3D9.1C2DCF7A65 & G720883B8 & Good & Female & Intact & 57.1 & 1.46 & $4 / 12 / 2013$ & 761 \\
\hline ASO & 3D9.1C2DB2FB18 & G720A0B67 & Fair & Female & Intact & 67.4 & 2.18 & $4 / 12 / 2013$ & 761 \\
\hline ASO & 3D9.1C2E09B53B & G720F3B26 & Good & Female & Intact & 69.4 & 2.42 & $4 / 12 / 2013$ & 761 \\
\hline ASO & 3D9.1C2DC881BE & G72106E36 & Good & Female & Intact & 62.5 & 1.94 & $4 / 12 / 2013$ & 761 \\
\hline ASO & 3D9.1C2E081BE9 & G7212CDEA & Good & Female & Intact & 69.1 & 2.96 & $4 / 12 / 2013$ & 761 \\
\hline ASO & 3D9.1C2E09DB03 & G72150D4E & Fair & Female & Intact & 70.6 & 2.68 & $4 / 12 / 2013$ & 761 \\
\hline ASO & 3D9.1C2E00A0CA & G7217B793 & Good & Female & Intact & 56.6 & 1.52 & $4 / 12 / 2013$ & 761 \\
\hline ASO & 3D9.1C2D858FD6 & G7217F3B4 & Good & Female & Intact & 66.2 & 2.10 & $4 / 12 / 2013$ & 761 \\
\hline
\end{tabular}


Table B.1. (contd)

\begin{tabular}{|c|c|c|c|c|c|c|c|c|c|}
\hline $\begin{array}{l}\text { Tagging } \\
\text { Site }\end{array}$ & PIT Tag \# & JSATS Tag \# & $\begin{array}{l}\text { Condition } \\
\text { (Good/Fair) }\end{array}$ & $\begin{array}{c}\text { Sex } \\
\text { (Male/Female) }\end{array}$ & $\begin{array}{c}\text { Adipose Fin } \\
\text { (Intact/Clipped) }\end{array}$ & $\begin{array}{l}\text { Length } \\
(\mathrm{cm})\end{array}$ & $\begin{array}{l}\text { Weight } \\
\text { (kg) }\end{array}$ & Release Date & $\begin{array}{c}\text { Release } \\
\text { rkm }\end{array}$ \\
\hline ASO & 3D9.1C2E09F4C3 & G724F135C & Good & Female & Intact & 63.1 & 1.88 & $4 / 12 / 2013$ & 761 \\
\hline ASO & 3D9.1C2DB0866D & G724F455A & Fair & Female & Intact & 69.5 & 2.20 & $4 / 12 / 2013$ & 761 \\
\hline ASO & 3D9.1C2E0865D9 & G72516A08 & Fair & Female & Intact & 63.4 & 2.04 & $4 / 12 / 2013$ & 761 \\
\hline ASO & 3D9.1C2E0894A2 & G725269BF & Good & Female & Intact & 65.1 & 2.08 & $4 / 12 / 2013$ & 761 \\
\hline ASO & 3D9.1C2E096301 & G72138AEB & Good & Female & Intact & 69.1 & & $4 / 15 / 2013$ & 761 \\
\hline ASO & 3D9.1C2E08E76C & G72139156 & Good & Male & Intact & 56.4 & & $4 / 15 / 2013$ & 761 \\
\hline ASO & 3D9.1C2E085827 & G7213C811 & Good & Female & Intact & 66.5 & & $4 / 15 / 2013$ & 761 \\
\hline ASO & 3D9.1C2E09E51C & G721632E4 & Fair & Female & Intact & 63.5 & & $4 / 15 / 2013$ & 761 \\
\hline ASO & 3D9.1C2DCE1090 & G720A2B44 & Fair & Male & Intact & 58.0 & 1.52 & $4 / 16 / 2013$ & 761 \\
\hline ASO & 3D9.1C2DB1F9A1 & G720FCA0C & Good & Female & Intact & 68.2 & 2.22 & $4 / 16 / 2013$ & 761 \\
\hline ASO & 3D9.1C2E090F04 & G7216691F & Good & Female & Intact & 71.6 & 2.64 & $4 / 16 / 2013$ & 761 \\
\hline ASO & 3D9.1C2E092425 & G721749F8 & Good & Female & Intact & 69.0 & 2.48 & $4 / 16 / 2013$ & 761 \\
\hline ASO & 3D9.1C2E093F4A & G72178591 & Good & Male & Intact & 53.7 & 1.26 & $4 / 16 / 2013$ & 761 \\
\hline ASO & 3D9.1C2DCE2499 & G7229C147 & Fair & Female & Intact & 63.5 & 1.62 & $4 / 16 / 2013$ & 761 \\
\hline ASO & 3D9.1C2E08EB1E & G7212673B & Good & Female & Intact & 58.0 & 1.52 & $4 / 17 / 2013$ & 761 \\
\hline ASO & 3D9.1C2E01E58C & G72140A09 & Good & Female & Intact & 52.7 & 1.14 & $4 / 17 / 2013$ & 761 \\
\hline ASO & 3D9.1C2DCE64EF & G7217F9CA & Good & Female & Intact & 62.4 & 1.82 & $4 / 17 / 2013$ & 761 \\
\hline ASO & 3D9.1C2E095583 & G7229E505 & Good & Female & Intact & 63.5 & 2.28 & 4/17/2013 & 761 \\
\hline ASO & 3D9.1C2E08A696 & G720F19B9 & Fair & Female & Intact & 67.5 & 1.88 & $4 / 18 / 2013$ & 761 \\
\hline ASO & 3D9.1C2E09392F & G7209953C & Good & Female & Intact & 67.0 & 2.28 & $4 / 19 / 2013$ & 761 \\
\hline ASO & 3D9.1C2E096835 & G7215B4E0 & Fair & Male & Intact & 65.2 & 2.16 & 4/19/2013 & 761 \\
\hline ASO & 3D9.1C2DAC6748 & G7229D084 & Fair & Female & Intact & 76.7 & 3.14 & 4/19/2013 & 761 \\
\hline ASO & 3D9.1C2E09FED8 & G720F4BDE & Fair & Female & Intact & 71.0 & 2.80 & $4 / 22 / 2013$ & 761 \\
\hline ASO & 3D9.1C2E08B6F3 & G7210DDE6 & Good & Female & Intact & 57.5 & 1.40 & $4 / 22 / 2013$ & 761 \\
\hline ASO & 3D9.1C2DCE8A95 & G7211E2DD & Good & Female & Intact & 67.9 & 2.08 & $4 / 22 / 2013$ & 761 \\
\hline ASO & 3D9.1C2E0A14E1 & G7213B7A8 & Good & Female & Intact & 65.9 & 2.20 & $4 / 22 / 2013$ & 761 \\
\hline ASO & 3D9.1C2E08B9A0 & G7208A6A4 & Good & Female & Intact & 58.0 & 1.34 & $4 / 23 / 2013$ & 761 \\
\hline ASO & 3D9.1C2E095829 & G720B259F & Fair & Female & Intact & 72.3 & 2.86 & $4 / 23 / 2013$ & 761 \\
\hline ASO & 3D9.1C2E01F148 & G720ED3C9 & Good & Male & Intact & 55.5 & & $4 / 23 / 2013$ & 761 \\
\hline ASO & 3D9.1C2E0A07CA & G72113A48 & Fair & Female & Intact & 69.9 & 2.28 & $4 / 23 / 2013$ & 761 \\
\hline
\end{tabular}


Table B.1. (contd)

\begin{tabular}{|c|c|c|c|c|c|c|c|c|c|}
\hline $\begin{array}{l}\text { Tagging } \\
\text { Site }\end{array}$ & PIT Tag \# & JSATS Tag \# & $\begin{array}{l}\text { Condition } \\
\text { (Good/Fair) }\end{array}$ & $\begin{array}{c}\text { Sex } \\
\text { (Male/Female) }\end{array}$ & $\begin{array}{c}\text { Adipose Fin } \\
\text { (Intact/Clipped) }\end{array}$ & $\begin{array}{l}\text { Length } \\
\text { (cm) }\end{array}$ & $\begin{array}{c}\text { Weight } \\
(\mathrm{kg})\end{array}$ & Release Date & $\begin{array}{c}\text { Release } \\
\text { rkm }\end{array}$ \\
\hline ASO & 3D9.1C2E01D9C2 & G7214ABF8 & Good & Female & Intact & 65.0 & & $4 / 23 / 2013$ & 761 \\
\hline ASO & 3D9.1C2DAC6049 & G72162807 & Good & Female & Intact & 70.0 & 2.82 & $4 / 23 / 2013$ & 761 \\
\hline ASO & 3D9.1C2E01CB4A & G7217C0E8 & Good & Female & Intact & 61.8 & & $4 / 23 / 2013$ & 761 \\
\hline ASO & 3D9.1C2D85B5CF & G722A4F81 & Good & Female & Intact & 57.7 & 1.24 & $4 / 23 / 2013$ & 761 \\
\hline ASO & 3D9.1C2E01A18D & G72093AD2 & Good & Male & Intact & 48.3 & 1.24 & $4 / 24 / 2013$ & 761 \\
\hline ASO & 3D9.1C2E0867DD & G720B88CD & Fair & Female & Intact & 52.3 & 1.16 & $4 / 24 / 2013$ & 761 \\
\hline ASO & 3D9.1C2E09C4FF & G7211B358 & Good & Female & Intact & 64.0 & 1.90 & $4 / 24 / 2013$ & 761 \\
\hline ASO & 3D9.1C2E08D3A8 & G7211EA1F & Good & Male & Intact & 52.1 & 1.28 & $4 / 24 / 2013$ & 761 \\
\hline PEW & 3D9.1C2D9C22F9 & G720968B5 & Fair & Female & Intact & 73.1 & 2.80 & $4 / 25 / 2013$ & 836 \\
\hline PEW & 3D9.1C2D9CC635 & G7215845E & Good & Female & Intact & 72.2 & 2.68 & $4 / 25 / 2013$ & 836 \\
\hline PEW & 3D9.1C2D9DF147 & G72176A39 & Good & Female & Intact & 70.6 & 2.65 & $4 / 25 / 2013$ & 836 \\
\hline PEW & 3D9.1C2D9C5BC3 & G7209FA18 & Good & Female & Intact & 67.3 & 2.94 & $4 / 26 / 2013$ & 836 \\
\hline PEW & 3D9.1C2D99D8B6 & G7211AB07 & Good & Female & Intact & 71.8 & 3.04 & $4 / 26 / 2013$ & 836 \\
\hline PEW & 3D9.1C2D9CDB64 & G720B24C1 & Good & Female & Intact & 74.6 & 2.98 & $4 / 27 / 2013$ & 836 \\
\hline PEW & 3D9.1C2D9C238D & G721624A4 & Good & Female & Intact & 72.9 & 3.12 & $4 / 27 / 2013$ & 836 \\
\hline PEW & 3D9.1C2D75C1AB & G720F2227 & Good & Male & Intact & 68.8 & 2.51 & $4 / 29 / 2013$ & 836 \\
\hline PEW & 3D9.1C2D9EB70C & G72097308 & Fair & Female & Intact & 79.0 & 3.57 & $5 / 3 / 2013$ & 836 \\
\hline PEW & 3D9.1C2D9BD432 & G72175FB8 & Fair & Female & Intact & 71.6 & 2.45 & $5 / 3 / 2013$ & 836 \\
\hline PEW & 3D9.1C2D9EE8E3 & G721315BB & Good & Male & Intact & 74.0 & 2.54 & $5 / 5 / 2013$ & 836 \\
\hline PEW & 3D9.1C2D9DAB86 & G7214B698 & Good & Female & Intact & 73.9 & 3.03 & $5 / 5 / 2013$ & 836 \\
\hline PEW & 3D9.1C2CF746F7 & G722995FD & Fair & Female & Intact & 72.7 & 3.02 & $5 / 5 / 2013$ & 836 \\
\hline PEW & 3D9.1C2D9D9CA7 & G720B3DC0 & Good & Female & Intact & 58.2 & 1.50 & 5/8/2013 & 836 \\
\hline PEW & 3D9.1C2D873A7D & G7229B823 & Good & Female & Intact & 69.2 & 2.50 & $5 / 8 / 2013$ & 836 \\
\hline PEW & 3D9.1C2D88BC4C & G72107928 & Good & Male & Intact & 53.4 & 1.20 & 5/9/2013 & 836 \\
\hline PEW & 3D9.1C2D9BB6FC & G72087511 & Good & Female & Intact & 72.6 & 2.65 & $5 / 15 / 2013$ & 836 \\
\hline JOS & 3D9.1C2DB1ED82 & G720AE673 & Good & Female & Intact & 65.8 & 2.18 & $4 / 11 / 2013$ & 804 \\
\hline JOS & 3D9.1C2D484035 & G721195A6 & Good & Female & Intact & 68.8 & 2.30 & $4 / 11 / 2013$ & 804 \\
\hline JOS & 3D9.1C2D47E10E & G72182DE4 & Good & Female & Intact & 67.5 & 2.30 & $4 / 11 / 2013$ & 804 \\
\hline JOS & 3D9.1C2D4773B0 & G722A4D3D & Fair & Female & Intact & 55.7 & 1.30 & $4 / 11 / 2013$ & 804 \\
\hline JOS & 3D9.1C2D451F6A & G725079B3 & Fair & Female & Intact & 74.4 & 3.02 & $4 / 11 / 2013$ & 804 \\
\hline
\end{tabular}


Table B.1. (contd)

\begin{tabular}{|c|c|c|c|c|c|c|c|c|c|}
\hline $\begin{array}{l}\text { Tagging } \\
\text { Site }\end{array}$ & PIT Tag \# & JSATS Tag \# & $\begin{array}{l}\text { Condition } \\
\text { (Good/Fair) }\end{array}$ & $\begin{array}{c}\text { Sex } \\
\text { (Male/Female) }\end{array}$ & $\begin{array}{c}\text { Adipose Fin } \\
\text { (Intact/Clipped) }\end{array}$ & $\begin{array}{l}\text { Length } \\
(\mathrm{cm})\end{array}$ & $\begin{array}{l}\text { Weight } \\
\text { (kg) }\end{array}$ & Release Date & $\begin{array}{c}\text { Release } \\
\text { rkm }\end{array}$ \\
\hline JOS & 3D9.1C2D47E9B1 & G725150C8 & Good & Female & Intact & 70.4 & 2.52 & $4 / 11 / 2013$ & 804 \\
\hline JOS & 3D9.1C2D48050D & G72527AC0 & Good & Female & Intact & 63.9 & 2.02 & $4 / 11 / 2013$ & 804 \\
\hline JOS & 3D9.1C2D453CAB & G721672A2 & Good & Female & Clipped & 58.7 & 1.70 & $4 / 11 / 2013$ & 804 \\
\hline JOS & 3D9.1C2D476D2C & G72085DF0 & Good & Female & Intact & 74.6 & 3.88 & $4 / 12 / 2013$ & 804 \\
\hline JOS & 3D9.1C2D453025 & G720A3624 & Good & Female & Intact & 67.1 & 2.14 & $4 / 12 / 2013$ & 804 \\
\hline JOS & 3D9.1C2D47772F & G720F01E6 & Fair & Female & Intact & 62.1 & 1.72 & $4 / 12 / 2013$ & 804 \\
\hline JOS & 3D9.1C2D451AF7 & G721367FF & Good & Female & Intact & 68.2 & 2.34 & $4 / 12 / 2013$ & 804 \\
\hline JOS & 3D9.1C2D4845EC & G724FDE6B & Good & Female & Intact & 72.6 & 3.02 & $4 / 12 / 2013$ & 804 \\
\hline JOS & 3D9.1C2D47486C & G724FE5F5 & Good & Female & Intact & 55.7 & 1.50 & $4 / 12 / 2013$ & 804 \\
\hline JOS & 3D9.1C2D45360F & G7250D4E1 & Good & Female & Intact & 73.6 & 2.94 & $4 / 12 / 2013$ & 804 \\
\hline JOS & 3D9.1C2D482FA4 & G72520B66 & Good & Female & Intact & 76.2 & 2.62 & $4 / 12 / 2013$ & 804 \\
\hline JOS & 3D9.1C2D453A85 & G722A1798 & Good & Female & Intact & 66.2 & 2.06 & $4 / 14 / 2013$ & 804 \\
\hline JOS & 3D9.1C2D479F53 & G724F46B8 & Good & Female & Intact & 57.1 & 1.46 & $4 / 14 / 2013$ & 804 \\
\hline JOS & 3D9.1C2D47BE21 & G72085F4C & Good & Female & Intact & 59.8 & 1.52 & $4 / 15 / 2013$ & 804 \\
\hline JOS & 3D9.1C2D4889EC & G7209E49A & Good & Female & Intact & 72.2 & 2.70 & $4 / 15 / 2013$ & 804 \\
\hline JOS & 3D9.1C2D475F3A & G720A0119 & Good & Female & Intact & 59.3 & 1.64 & $4 / 15 / 2013$ & 804 \\
\hline JOS & 3D9.1C2D47F348 & G721186D9 & Good & Female & Intact & 68.5 & 2.40 & $4 / 15 / 2013$ & 804 \\
\hline JOS & 3D9.1C2D482D61 & G7211E6BC & Good & Female & Intact & 68.2 & 2.24 & $4 / 15 / 2013$ & 804 \\
\hline JOS & 3D9.1C2D4853D9 & G72151B0E & Good & Female & Intact & 70.3 & 2.82 & $4 / 15 / 2013$ & 804 \\
\hline JOS & 3D9.1C2D4800FF & G722A0C25 & Fair & Male & Intact & 56.8 & 1.48 & $4 / 15 / 2013$ & 804 \\
\hline JOS & 3D9.1C2D487345 & G72087A50 & Good & Female & Intact & 64.7 & 2.12 & $4 / 17 / 2013$ & 804 \\
\hline JOS & 3D9.1C2D4759AD & G72088687 & Fair & Male & Intact & 53.4 & 1.42 & $4 / 17 / 2013$ & 804 \\
\hline JOS & 3D9.1C2D4879E5 & G720FEDAC & Good & Female & Intact & 75.2 & 3.18 & $4 / 17 / 2013$ & 804 \\
\hline JOS & 3D9.1C2D4733AC & G72157B6B & Good & Female & Intact & 65.3 & 2.22 & $4 / 17 / 2013$ & 804 \\
\hline JOS & 3D9.1C2D4776A3 & G721775E5 & Good & Female & Intact & 65.7 & 2.24 & $4 / 17 / 2013$ & 804 \\
\hline JOS & 3D9.1C2D47E755 & G7208FADC & Good & Female & Intact & 76.7 & 3.20 & $4 / 18 / 2013$ & 804 \\
\hline JOS & 3D9.1C2D4737A2 & G72107876 & Good & Female & Intact & 63.0 & 1.74 & $4 / 18 / 2013$ & 804 \\
\hline JOS & 3D9.1C2D4775B0 & G72120261 & Good & Female & Intact & 71.5 & 2.64 & $4 / 18 / 2013$ & 804 \\
\hline JOS & 3D9.1C2D475850 & G7216389A & Fair & Female & Intact & 66.4 & 2.60 & $4 / 18 / 2013$ & 804 \\
\hline JOS & 3D9.1C2D4800FE & G72188874 & Good & Female & Intact & 70.6 & 2.64 & $4 / 18 / 2013$ & 804 \\
\hline
\end{tabular}


Table B.1. (contd)

\begin{tabular}{|c|c|c|c|c|c|c|c|c|c|}
\hline $\begin{array}{l}\text { Tagging } \\
\text { Site }\end{array}$ & PIT Tag \# & JSATS Tag \# & $\begin{array}{l}\text { Condition } \\
\text { (Good/Fair) }\end{array}$ & $\begin{array}{c}\text { Sex } \\
\text { (Male/Female) }\end{array}$ & $\begin{array}{c}\text { Adipose Fin } \\
\text { (Intact/Clipped) }\end{array}$ & $\begin{array}{l}\text { Length } \\
(\mathrm{cm})\end{array}$ & $\begin{array}{l}\text { Weight } \\
\text { (kg) }\end{array}$ & Release Date & $\begin{array}{c}\text { Release } \\
\text { rkm }\end{array}$ \\
\hline JOS & 3D9.1C2D4826F4 & G720821AB & Good & Female & Intact & 48.7 & 1.02 & $4 / 19 / 2013$ & 804 \\
\hline JOS & 3D9.1C2D4865E0 & G7229C2A5 & Fair & Female & Intact & 62.8 & 2.02 & 4/19/2013 & 804 \\
\hline JOS & 3D9.1C2D4772DE & G720F2BBB & Good & Female & Intact & 71.1 & 2.60 & $4 / 20 / 2013$ & 804 \\
\hline JOS & 3D9.1C2D488139 & G72121F01 & Good & Female & Intact & 71.7 & 2.96 & $4 / 20 / 2013$ & 804 \\
\hline JOS & 3D9.1C2D483E8A & G721375DE & Fair & Female & Intact & 67.3 & 2.50 & $4 / 20 / 2013$ & 804 \\
\hline JOS & 3D9.1C2D481700 & G72152852 & Fair & Female & Intact & 57.5 & 1.46 & $4 / 20 / 2013$ & 804 \\
\hline JOS & 3D9.1C2D45130D & G721540F5 & Fair & Female & Intact & 67.6 & 2.26 & $4 / 20 / 2013$ & 804 \\
\hline JOS & 3D9.1C2D489343 & G720A8F8A & Good & Female & Intact & 66.1 & 2.52 & $4 / 22 / 2013$ & 804 \\
\hline JOS & 3D9.1C2DCE27C2 & G7229B1BF & Good & Male & Intact & 59.8 & 1.80 & $4 / 22 / 2013$ & 804 \\
\hline JOS & 3D9.1C2D4785AA & G7229BA9F & Good & Female & Intact & 71.9 & 2.90 & $4 / 22 / 2013$ & 804 \\
\hline JOS & 3D9.1C2D484FAA & G720B36E0 & Good & Female & Intact & 70.8 & 2.80 & 4/23/2013 & 804 \\
\hline JOS & 3D9.1C2DCE4BE6 & G7210FF79 & Good & Female & Intact & 55.7 & 1.24 & 4/23/2013 & 804 \\
\hline JOS & 3D9.1C2D473F5E & G7212DAF4 & Good & Female & Intact & 59.5 & 1.54 & $4 / 23 / 2013$ & 804 \\
\hline JOS & 3D9.1C2D485780 & G720820F5 & Good & Female & Intact & 67.6 & 2.52 & $4 / 24 / 2013$ & 804 \\
\hline JOS & 3D9.1C2D47A069 & G7215264D & Good & Female & Intact & 66.5 & 2.12 & $4 / 24 / 2013$ & 804 \\
\hline JOS & 3D9.1C2D454142 & G721625FA & Good & Female & Intact & 70.3 & 2.66 & $4 / 24 / 2013$ & 804 \\
\hline JOS & 3D9.1C2D4841BB & G7217A1D3 & Good & Female & Intact & 64.3 & 1.94 & $5 / 7 / 2013$ & 804 \\
\hline JOS & 3D9.1C2D489A48 & G72188735 & Good & Female & Intact & 65.2 & 1.92 & $5 / 7 / 2013$ & 804 \\
\hline JOS & 3D9.1C2D4809D7 & G720A7662 & Good & Female & Intact & 60.4 & 1.54 & 5/9/2013 & 804 \\
\hline JOS & & G7229CB39 & Good & Female & Intact & 67.2 & 2.34 & $5 / 9 / 2013$ & 804 \\
\hline JOS & 3D9.1C2D476B47 & G721063CB & Good & Female & Intact & 66.0 & 2.04 & $5 / 13 / 2013$ & 804 \\
\hline JOS & 3D9.1C2D47EFA2 & G72179F72 & Good & Male & Intact & 51.8 & 0.78 & $5 / 13 / 2013$ & 804 \\
\hline JOS & 3D9.1C2D476364 & G722A52E1 & Fair & Female & Intact & 70.7 & 2.01 & $5 / 17 / 2013$ & 804 \\
\hline JOS & 3D9.1C2DB0B3E9 & G720EE909 & Good & Female & Intact & 67.9 & 2.16 & $5 / 18 / 2013$ & 804 \\
\hline JOS & 3D9.1C2D475B19 & G72137EFE & Good & Female & Intact & 68.2 & 1.84 & $5 / 18 / 2013$ & 804 \\
\hline JOS & 3D9.1C2DB0AA47 & G7215D767 & Fair & Female & Intact & 54.7 & 1.06 & $5 / 18 / 2013$ & 804 \\
\hline JOS & 3D9.1C2D47F74C & G72181D5A & Good & Male & Intact & 49.2 & 0.94 & $5 / 18 / 2013$ & 804 \\
\hline JOS & 3D9.1C2DAC3833 & G7229E8F8 & Fair & Male & Intact & 52.9 & 1.24 & $5 / 19 / 2013$ & 804 \\
\hline FC & 3D9.1C2E085DA5 & G720B663B & Fair & Female & Intact & 90.0 & 5.90 & $5 / 22 / 2013$ & 944 \\
\hline FC & 3D9.1BF26B931E & G72103BD2 & Fair & Female & Intact & 83.0 & 4.28 & $5 / 22 / 2013$ & 944 \\
\hline
\end{tabular}


Table B.1. (contd)

\begin{tabular}{|c|c|c|c|c|c|c|c|c|c|}
\hline $\begin{array}{l}\text { Tagging } \\
\text { Site }\end{array}$ & PIT Tag \# & JSATS Tag \# & $\begin{array}{l}\text { Condition } \\
\text { (Good/Fair) }\end{array}$ & $\begin{array}{c}\text { Sex } \\
\text { (Male/Female) }\end{array}$ & $\begin{array}{c}\text { Adipose Fin } \\
\text { (Intact/Clipped) }\end{array}$ & $\begin{array}{l}\text { Length } \\
(\mathrm{cm})\end{array}$ & $\begin{array}{l}\text { Weight } \\
\text { (kg) }\end{array}$ & Release Date & $\begin{array}{c}\text { Release } \\
\text { rkm }\end{array}$ \\
\hline FC & 3D9.1C2E084A89 & G72112C08 & Fair & Female & Intact & 81.0 & 3.80 & $5 / 22 / 2013$ & 944 \\
\hline FC & 3D9.1BF26BFEFE & G72121CE3 & Good & Female & Intact & 80.0 & 4.18 & $5 / 23 / 2013$ & 944 \\
\hline FC & 3D9.1C2E08C95B & G7212B76C & Good & Female & Intact & 81.0 & 4.16 & $5 / 23 / 2013$ & 944 \\
\hline $\mathrm{FC}$ & 3D9.1C2E094CA8 & G7213BC88 & Good & Female & Intact & 80.0 & 3.88 & $5 / 23 / 2013$ & 944 \\
\hline FC & 3D9.1C2E08C894 & G7215E9C6 & Fair & Male & Intact & 82.0 & 3.96 & $5 / 23 / 2013$ & 944 \\
\hline FC & 3D9.1C2DB08E4D & G72150EAC & Good & Female & Intact & 78.0 & 3.45 & $5 / 24 / 2013$ & 944 \\
\hline $\mathrm{FC}$ & 3D9.1C2E01A23A & G7215A3FE & Good & Female & Intact & 76.0 & 3.10 & $5 / 24 / 2013$ & 944 \\
\hline FC & 3D9.1C2DAC1646 & G7215E104 & Good & Female & Intact & 81.0 & 3.68 & $5 / 24 / 2013$ & 944 \\
\hline FC & 3D9.1C2E085CE4 & G7210CE99 & Fair & Female & Intact & 84.0 & 4.00 & $5 / 25 / 2013$ & 944 \\
\hline FC & 3D9.1C2E092DFC & G72153F4C & Good & Female & Intact & 80.0 & 3.86 & $5 / 25 / 2013$ & 944 \\
\hline FC & 3D9.1C2E093BDF & G7214F8C1 & Good & Female & Intact & 81.0 & 4.36 & $5 / 27 / 2013$ & 944 \\
\hline FC & 3D9.1C2E085EFE & G72135800 & Good & Female & Intact & 59.0 & 1.66 & $5 / 28 / 2013$ & 944 \\
\hline FC & 3D9.1C2E08D370 & G7211F0FC & Good & Female & Intact & 80.0 & 3.82 & $5 / 30 / 2013$ & 944 \\
\hline $\mathrm{FC}$ & 3D9.1C2E08BF0B & G7215AA62 & Good & Female & Intact & 80.0 & 4.50 & $5 / 30 / 2013$ & 944 \\
\hline FC & 3D9.1C2E09228B & G7213CC70 & Good & Female & Intact & 80.0 & 3.50 & 5/31/2013 & 944 \\
\hline FC & 3D9.1C2E01F053 & G7215921E & Good & Female & Intact & 81.0 & 3.92 & 5/31/2013 & 944 \\
\hline FC & 3D9.1C2E01E4DD & G7211EF20 & Good & Female & Intact & 79.0 & 4.06 & 6/2/2013 & 944 \\
\hline FC & 3D9.1C2E095972 & G7212DE95 & Good & Female & Intact & 76.0 & 3.30 & 6/2/2013 & 944 \\
\hline FC & 3D9.1C2E07F513 & G72131C27 & Fair & Female & Intact & 83.0 & 4.38 & 6/2/2013 & 944 \\
\hline FC & 3D9.1C2E08DB33 & G721350C2 & Fair & Female & Intact & 79.0 & 3.54 & $6 / 2 / 2013$ & 944 \\
\hline $\mathrm{FC}$ & 3D9.1C2E019875 & G7214AC7B & Good & Female & Intact & 76.0 & 3.00 & $6 / 2 / 2013$ & 944 \\
\hline $\mathrm{FC}$ & 3D9.1C2E086BC1 & G72151C8D & Good & Female & Intact & 78.5 & 3.18 & 6/2/2013 & 944 \\
\hline FC & 3D9.1C2E01FABC & G72154BD5 & Good & Female & Intact & 85.0 & 4.30 & 6/3/2013 & 944 \\
\hline $\mathrm{FC}$ & 3D9.1C2E08D327 & G721289CD & Good & Female & Intact & 79.0 & 3.32 & 6/4/2013 & 944 \\
\hline FC & 3D9.1C2E01D81F & G7213A0B6 & Good & Female & Intact & 62.0 & 1.70 & $6 / 4 / 2013$ & 944 \\
\hline FC & 3D9.1C2E07FEED & G72141308 & Good & Female & Intact & 77.0 & 3.28 & 6/4/2013 & 944 \\
\hline FC & 3D9.1BF23E648E & G7213DDB3 & Fair & Female & Intact & 75.0 & 3.08 & 6/6/2013 & 944 \\
\hline FC & 3D9.1BF263197E & G7211D33D & Fair & Female & Intact & 77.0 & 3.16 & 6/7/2013 & 944 \\
\hline FC & 3D9.1C2E089E21 & G72122BDE & Good & Female & Intact & 79.0 & 3.36 & $6 / 7 / 2013$ & 944 \\
\hline FC & 3D9.1C2E01A191 & G7212FB89 & Good & Female & Intact & 81.0 & 3.68 & $6 / 7 / 2013$ & 944 \\
\hline
\end{tabular}


Table B.1. (contd)

\begin{tabular}{|c|c|c|c|c|c|c|c|c|c|}
\hline $\begin{array}{l}\text { Tagging } \\
\text { Site }\end{array}$ & PIT Tag \# & JSATS Tag \# & $\begin{array}{l}\text { Condition } \\
\text { (Good/Fair) }\end{array}$ & $\begin{array}{c}\text { Sex } \\
\text { (Male/Female) }\end{array}$ & $\begin{array}{c}\text { Adipose Fin } \\
\text { (Intact/Clipped) }\end{array}$ & $\begin{array}{l}\text { Length } \\
\text { (cm) }\end{array}$ & $\begin{array}{l}\text { Weight } \\
\text { (kg) }\end{array}$ & Release Date & $\begin{array}{c}\text { Release } \\
\text { rkm }\end{array}$ \\
\hline FC & 3D9.1C2E086BAE & G7213E773 & Good & Male & Intact & 59.0 & 1.64 & $6 / 7 / 2013$ & 944 \\
\hline FC & 3D9.1C2E01F34F & G721463F0 & Good & Female & Intact & 79.0 & 4.04 & 6/7/2013 & 944 \\
\hline FC & 3D9.1C2E018ABC & G72122FBF & Good & Female & Intact & 75.0 & 3.04 & 6/8/2013 & 944 \\
\hline FC & 3D9.1BF26BA5AD & G72131659 & Good & Female & Intact & 81.0 & 4.30 & 6/8/2013 & 944 \\
\hline FC & 3D9.1C2E07B38D & G7216503D & Good & Female & Intact & 79.0 & 3.40 & 6/9/2013 & 944 \\
\hline $\mathrm{FC}$ & 3D9.1C2E01A68D & G72145FED & Good & Female & Intact & 77.0 & 3.42 & $6 / 12 / 2013$ & 944 \\
\hline FC & 3D9.1C2E01931E & G72135D3F & Fair & Female & Intact & 74.0 & 2.64 & $6 / 13 / 2013$ & 944 \\
\hline FC & 3D9.1C2E0876FE & G72157DB6 & Good & Female & Intact & 76.0 & 2.88 & 6/13/2013 & 944 \\
\hline FC & 3D9.1C2C94CAC0 & G72158F7E & Fair & Female & Intact & 80.0 & 3.56 & $6 / 13 / 2013$ & 944 \\
\hline
\end{tabular}




\section{Appendix C}

Timing of Juvenile Salmon Acoustic Telemetry SystemTagged Kelts Passage versus Dam Discharge 


\section{Appendix C}

\section{Timing of Juvenile Salmon Acoustic Telemetry System- Tagged Kelts Passage versus Dam Discharge}

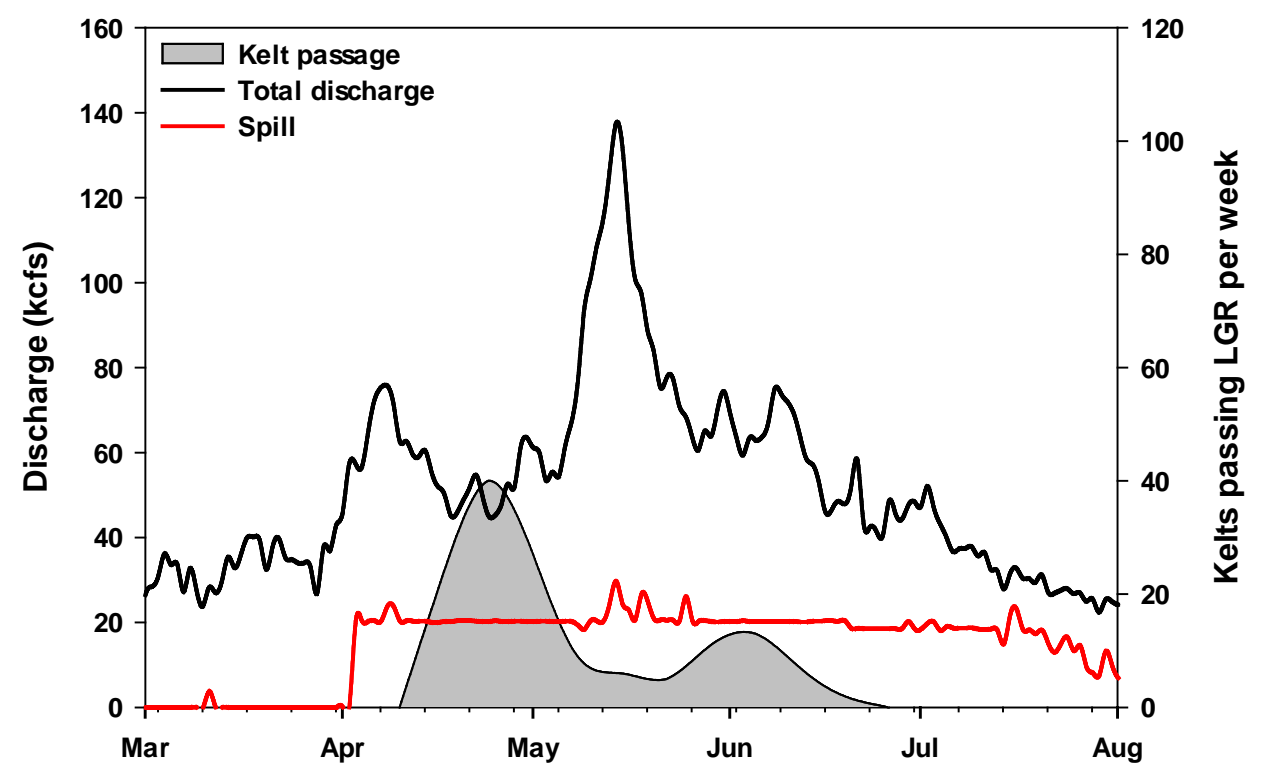

Figure C.1. Average daily total and spill discharge (kcfs) at Lower Granite Dam (LGR) from 1 March to 1 August 2013. Also shown are the numbers of kelts per week (Sunday-Saturday) detected passing LGR during the same period. Average daily discharge values represent averages of hourly measurements for each day. All discharge data were obtained from the DART website (Data Access in Real Time; http://www.cbr.washington.edu/dart/). 


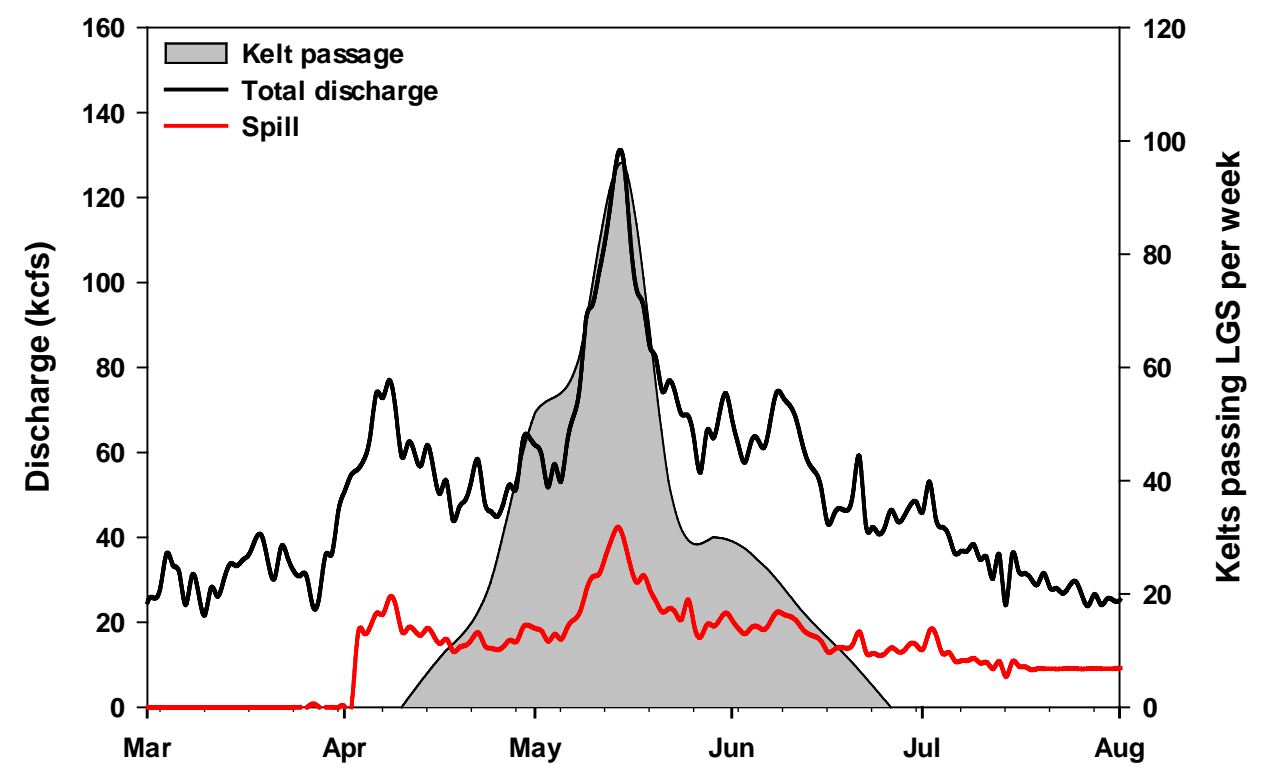

Figure C.2. Average daily total and spill discharge (kcfs) at Little Goose Dam (LGS) from 1 March to 1 August 2013. Also shown are the numbers of kelts per week (Sunday-Saturday) detected passing LGS during the same period. Average daily discharge values represent averages of hourly measurements for each day. All discharge data were obtained from the DART website (Data Access in Real Time; http://www.cbr.washington.edu/dart/).

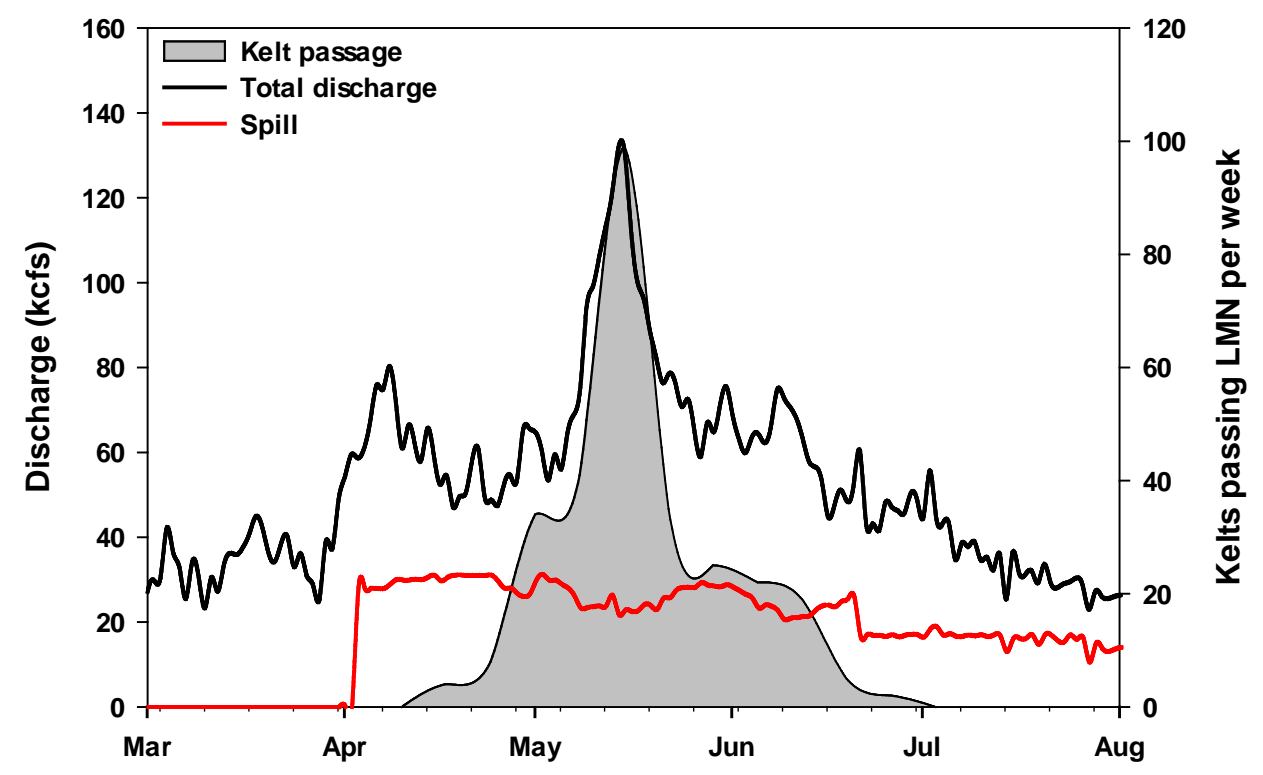

Figure C.3. Average daily total and spill discharge (kcfs) at Lower Monumental Dam (LMN) from 1 March to 1 August 2013. Also shown are the numbers of kelts per week (SundaySaturday) detected passing LMN during the same period. Average daily discharge values represent averages of hourly measurements for each day. All discharge data were obtained from the DART website (Data Access in Real Time; http://www.cbr.washington.edu/dart/). 


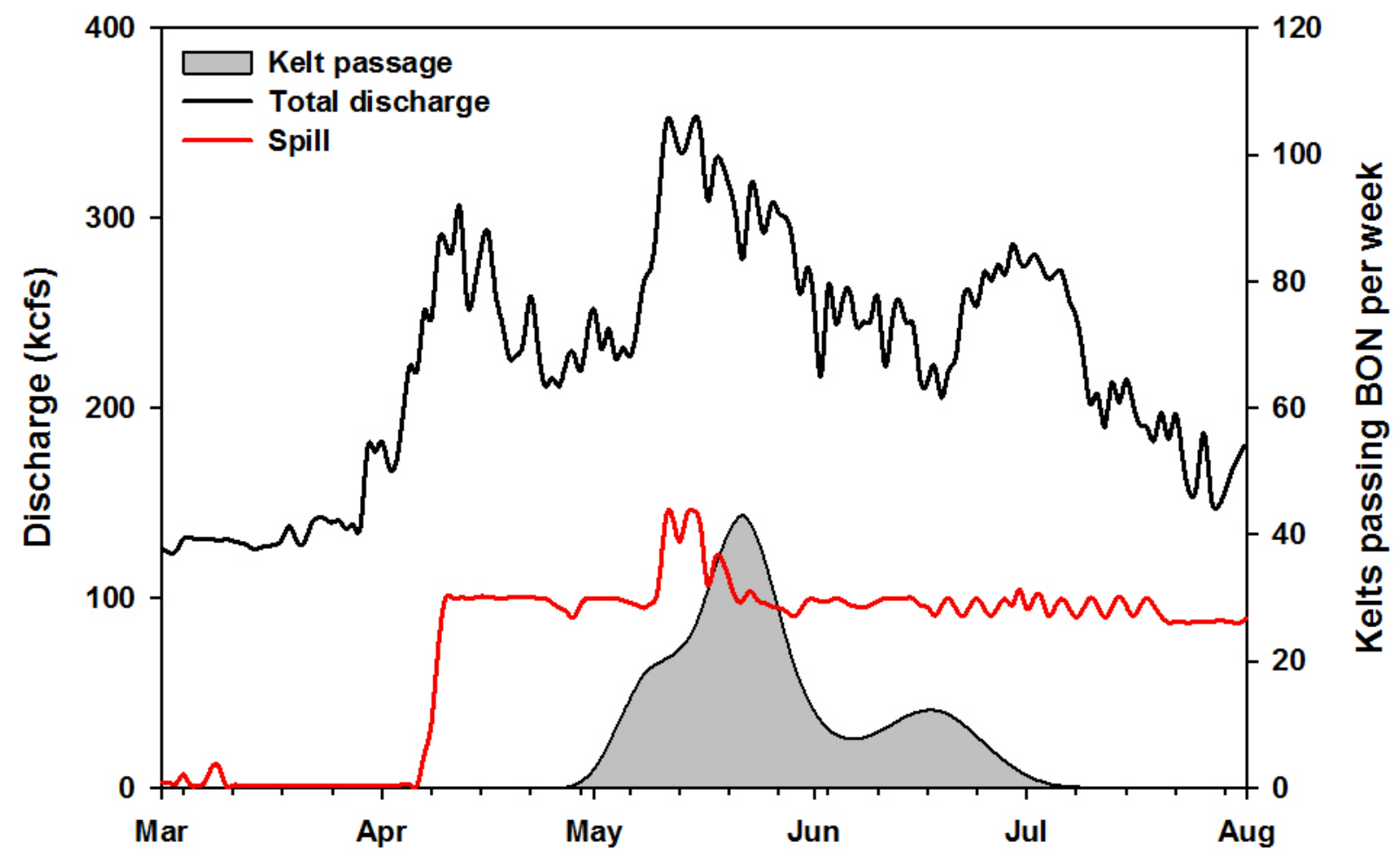

Figure C.4. Average daily total and spill discharge (kcfs) at Bonneville Dam (BON) from 1 March to 1 August 2013. Also shown are the numbers of kelts per week (Sunday - Saturday) detected passing the array in the BON forebay (rkm 236) during the same period. Average daily discharge values represent averages of hourly measurements for each day. All discharge data were obtained from the DART website (Data Access in Real Time; http://www.cbr.washington.edu/dart/). 
Appendix D

\section{Discharge versus Spill at Each Dam}




\section{Appendix D}

\section{Discharge versus Spill at Each Dam}

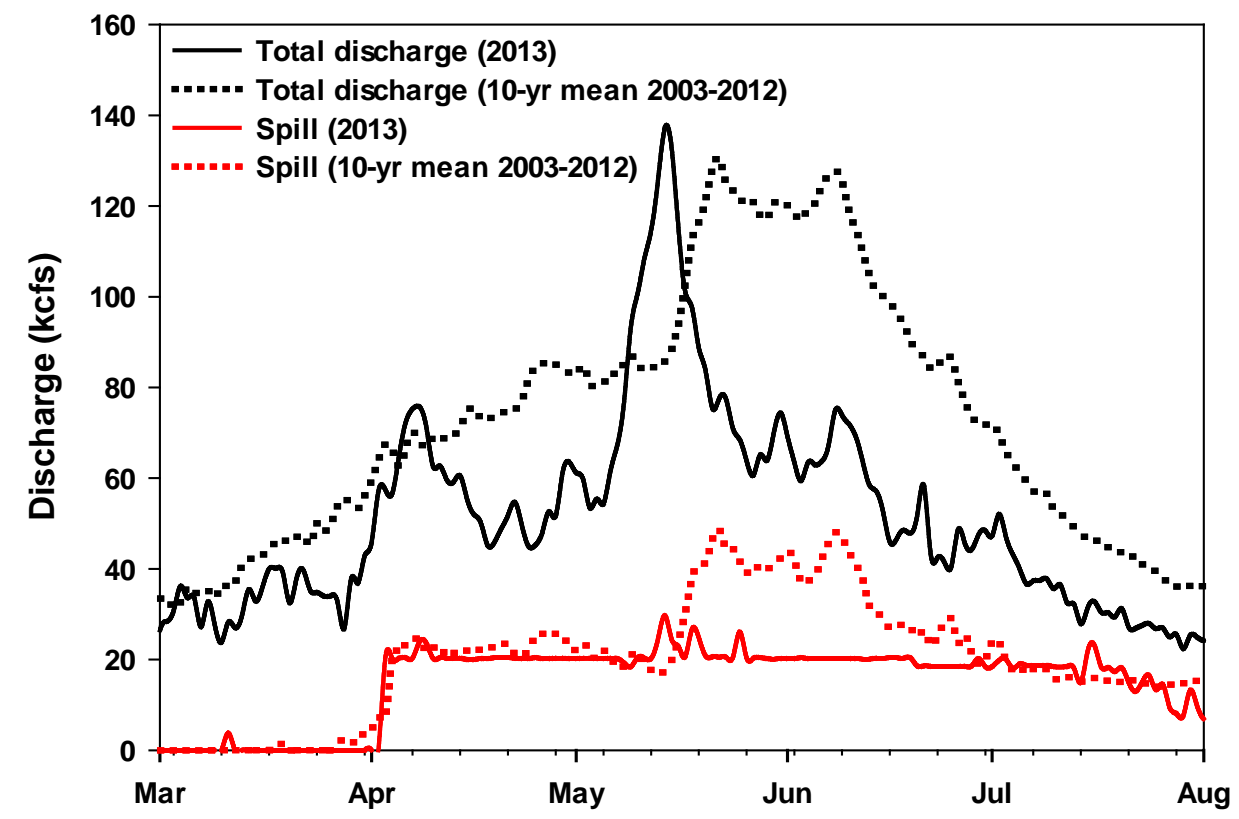

Figure D.1. The average daily total and spill discharge rates (kcfs) observed at Lower Granite Dam from 1 March to 1 August 2013, with 10-year averages. Average daily discharge values represent averages of hourly measurements for each day. All discharge data were obtained from the DART website (Data Access in Real Time; http://www.cbr.washington.edu/dart/). 


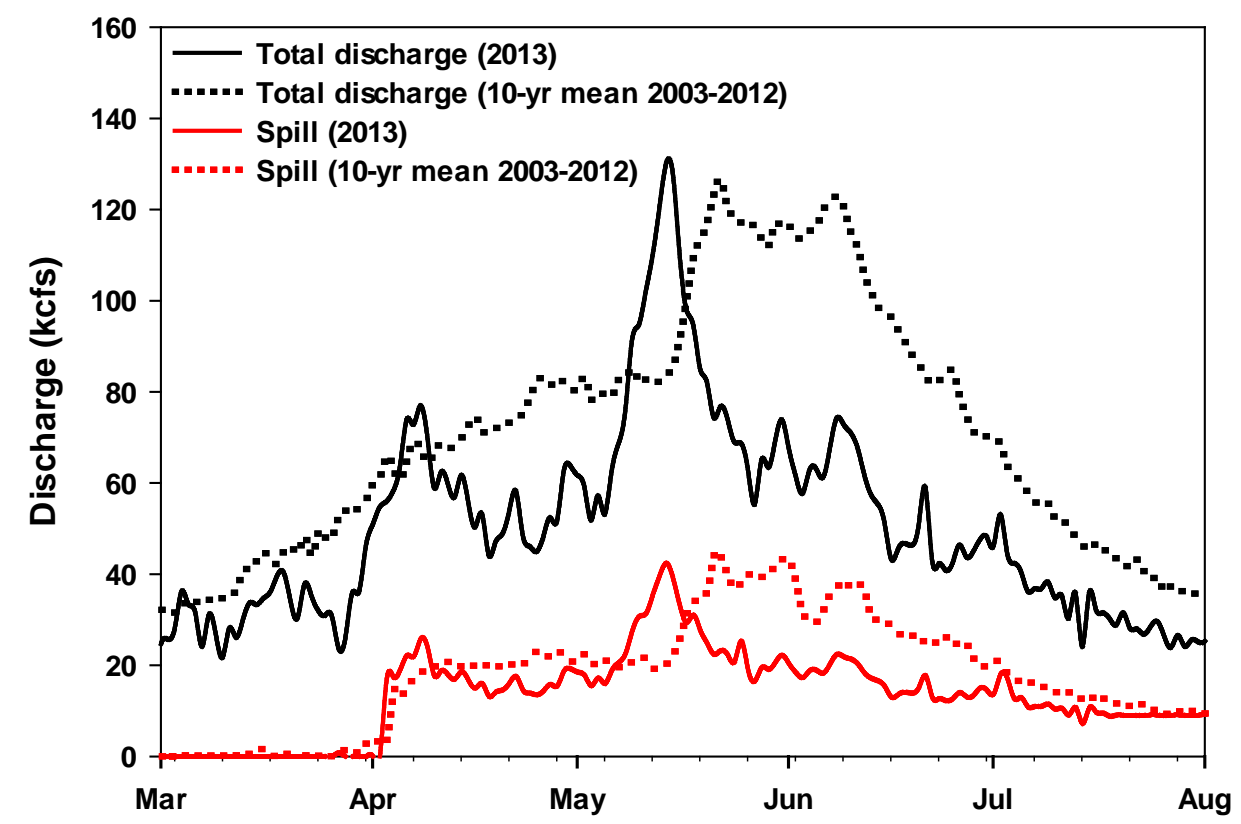

Figure D.2. The average daily total and spill discharge rates (kcfs) observed at Little Goose Dam from 1 March to 1 August 2013, with 10-year averages. Average daily discharge values represent averages of hourly measurements for each day. All discharge data were obtained from the DART website (Data Access in Real Time; http://www.cbr.washington.edu/dart/).

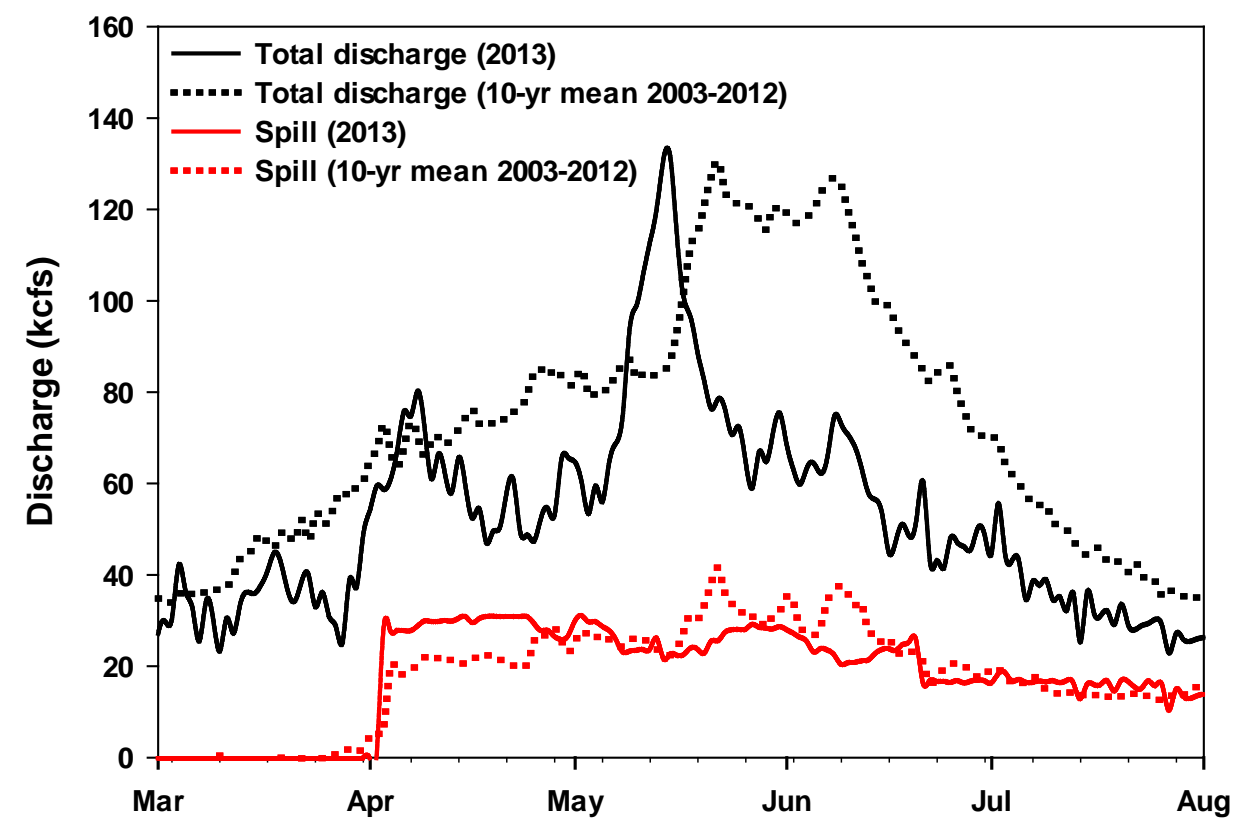

Figure D.3. The average daily total and spill discharge rates (kcfs) observed at Lower Monumental Dam from 1 March to 1 August 2013, with 10-year averages. Average daily discharge values represent averages of hourly measurements for each day. All discharge data were obtained from the DART website (Data Access in Real Time; http://www.cbr.washington.edu/dart/). 


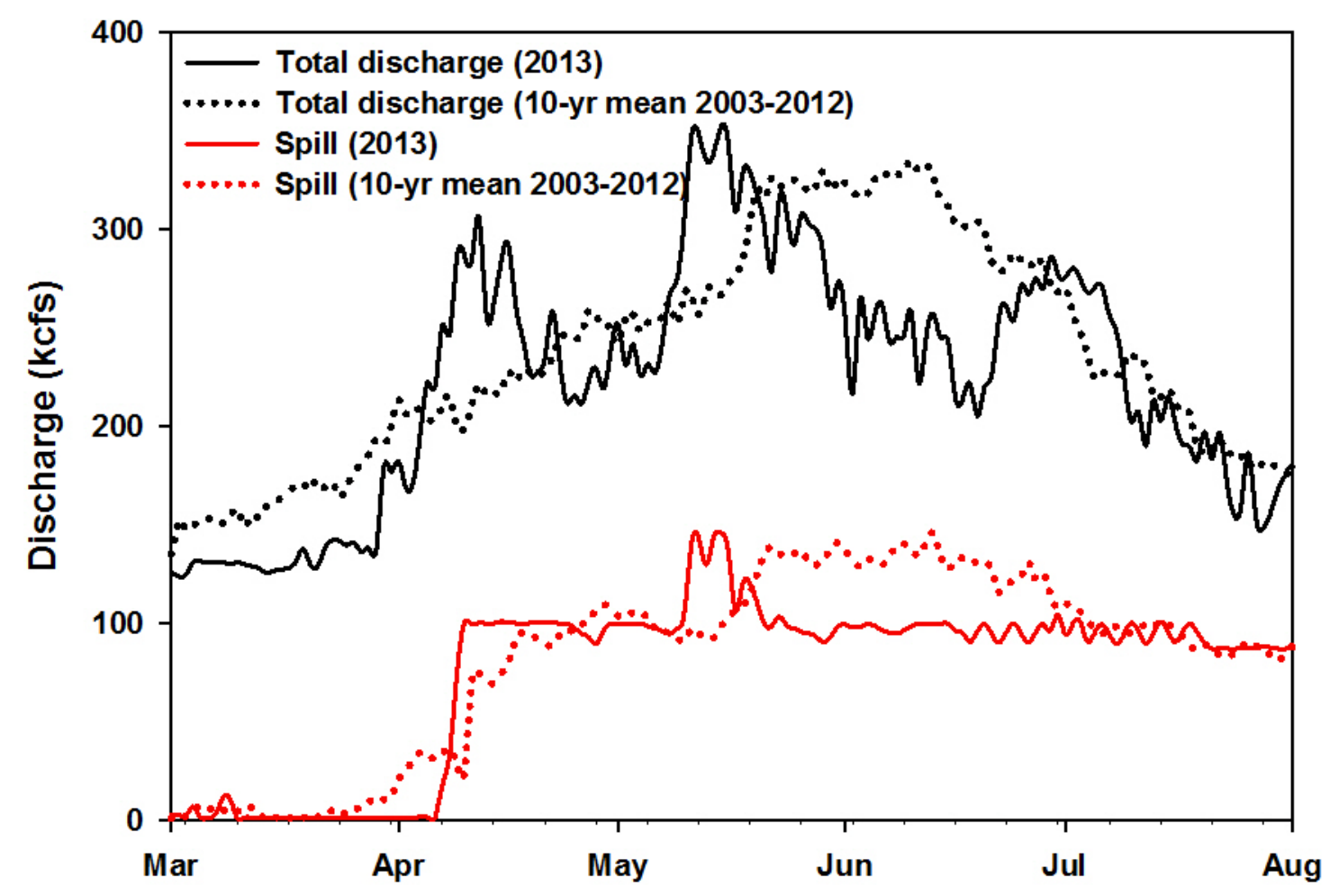

Figure D.4. The average daily total and spill discharge rates (kcfs) observed at Bonneville Dam from 1 March to 1 August 2013, with 10-year averages. Average daily discharge values represent averages of hourly measurements for each day. All discharge data were obtained from the DART website (Data Access in Real Time; http://www.cbr.washington.edu/dart/). 
Appendix E

\section{Timing of Kelt Passage versus Temperature}




\section{Appendix E}

\section{Timing of Kelt Passage versus Temperature}

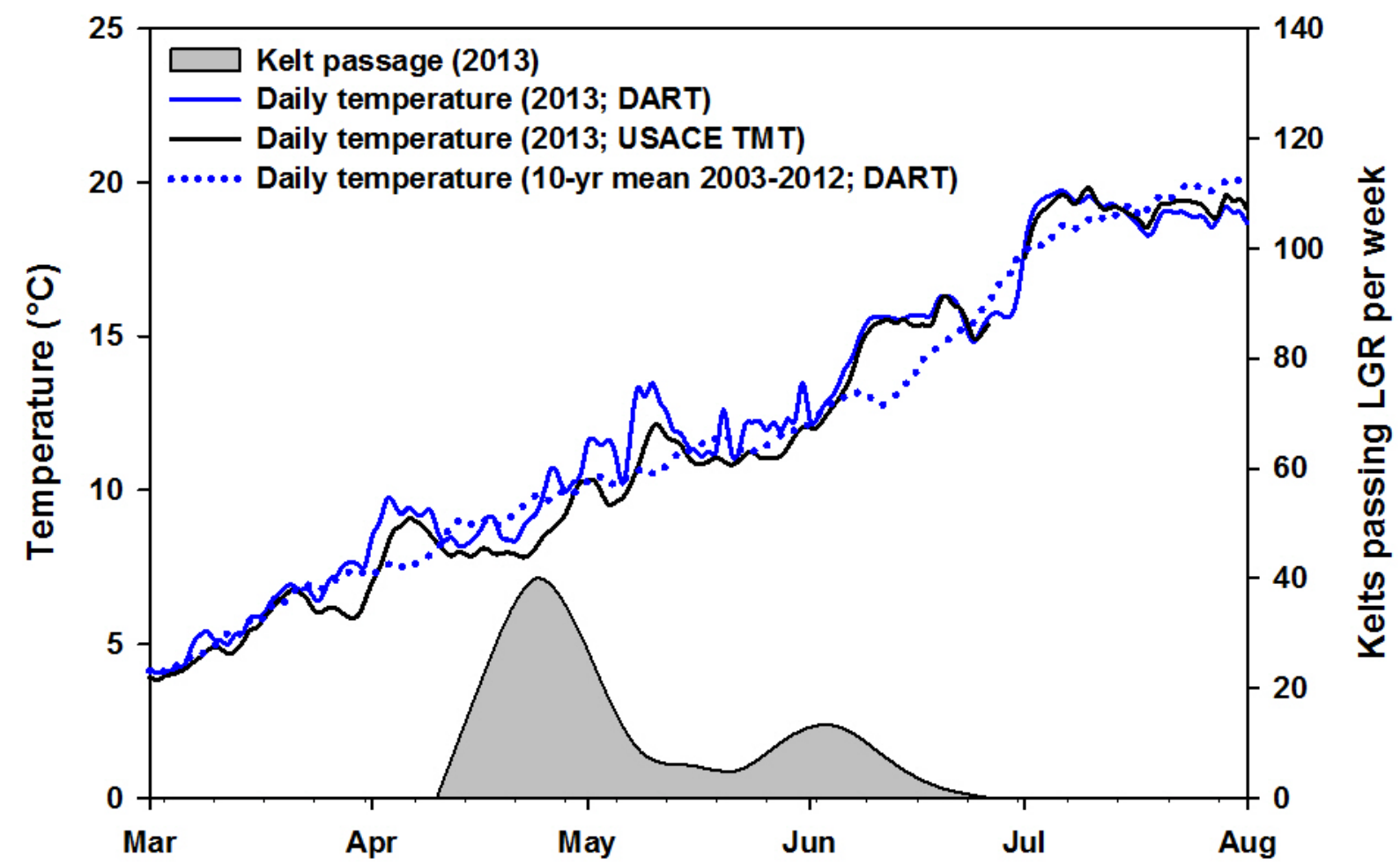

Figure E.1. Average daily forebay temperature $\left({ }^{\circ} \mathrm{C}\right)$ observed at Lower Granite Dam (LGR) from 1 March to 1 August 2013, with the 10-year average. Also shown are the numbers of kelts per week (Sunday-Saturday) detected passing LGR during the same period. Reported temperatures are daily averages as recorded at forebay water-quality monitoring stations. Temperature data were obtained from the DART website (Data Access in Real Time; http://www.cbr.washington.edu/dart/) and the USACE TMT (U.S. Army Corps of Engineers Technical Management Team; http://www.nwdwc.usace.army.mil/ftppub/water_quality/tempstrings/). 


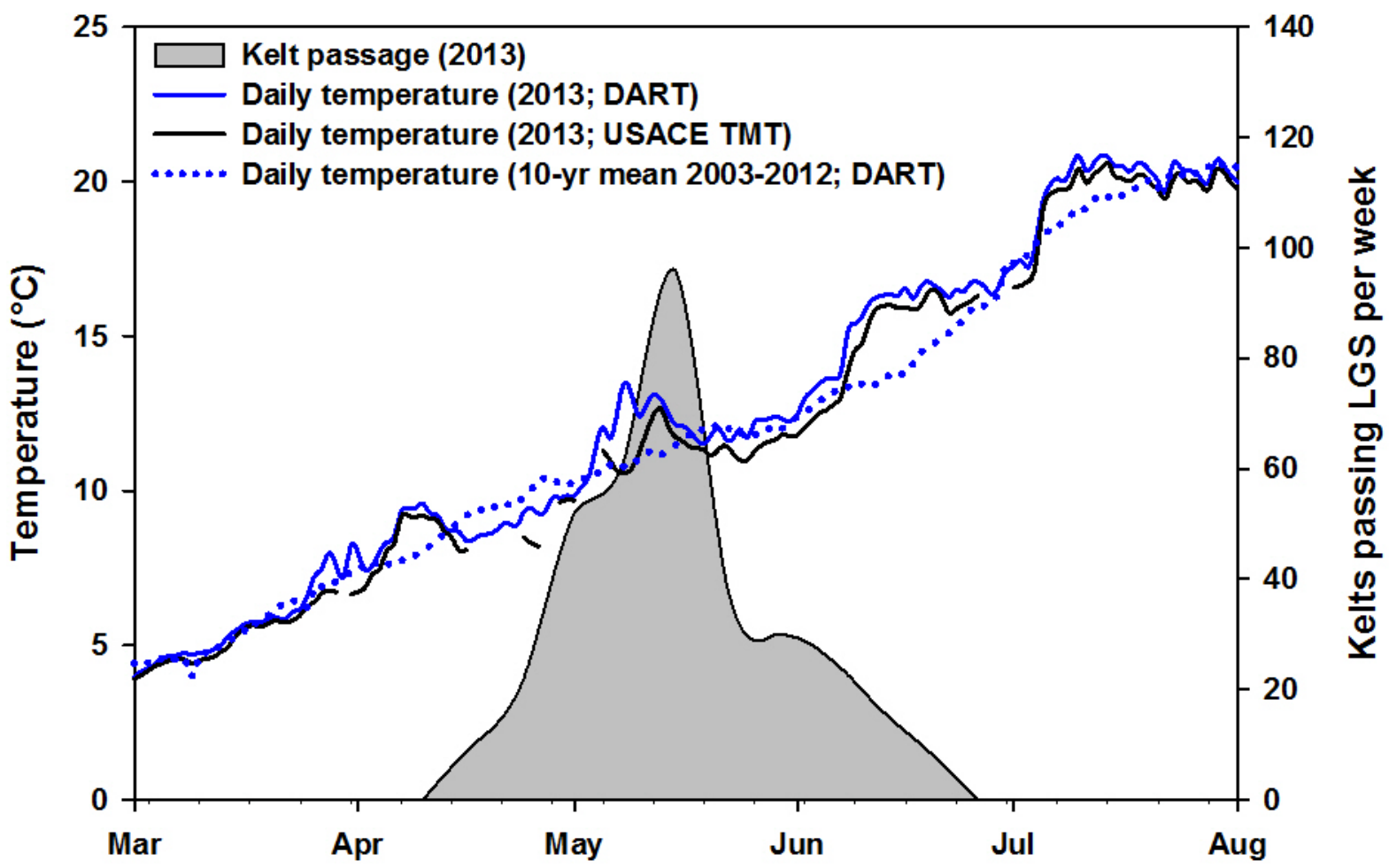

Figure E.2. Average daily forebay temperature $\left({ }^{\circ} \mathrm{C}\right)$ observed at Little Goose Dam (LGS) from 1 March to 1 August 2013, with the 10-year average. Also shown are the numbers of kelts per week (Sunday-Saturday) detected passing LGS during the same time period. Reported temperatures are daily averages as recorded at forebay water quality monitoring stations. Temperature data were obtained from the DART website (Data Access in Real Time; http://www.cbr.washington.edu/dart/) and the USACE TMT (US Army Corps of Engineers Technical Management Team; http://www.nwdwc.usace.army.mil/ftppub/water quality/tempstrings/). 


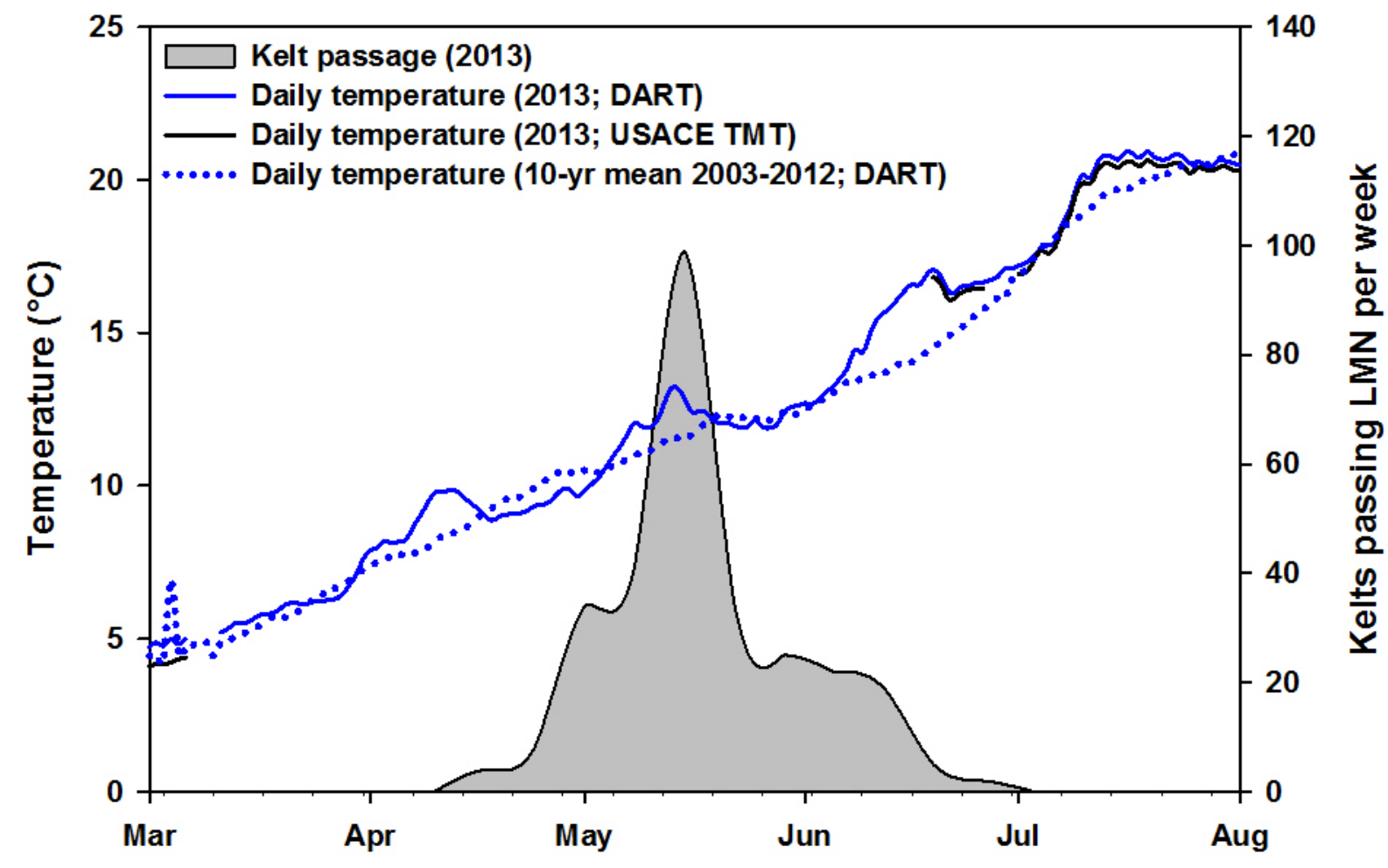

Figure E.3. Average daily forebay temperature $\left({ }^{\circ} \mathrm{C}\right)$ observed at Lower Monumental Dam (LMN) from 1 March to 1 August 2013, with the 10-year average. Also shown are the numbers of kelts per week (Sunday-Saturday) detected passing LMN during the same time period. Reported temperatures are daily averages as recorded at forebay water quality monitoring stations. Temperature data were obtained from the DART website (Data Access in Real Time; http://www.cbr.washington.edu/dart/) and the USACE TMT (US Army Corps of Engineers Technical Management Team; http://www.nwdwc.usace.army.mil/ftppub/water quality/tempstrings/). 


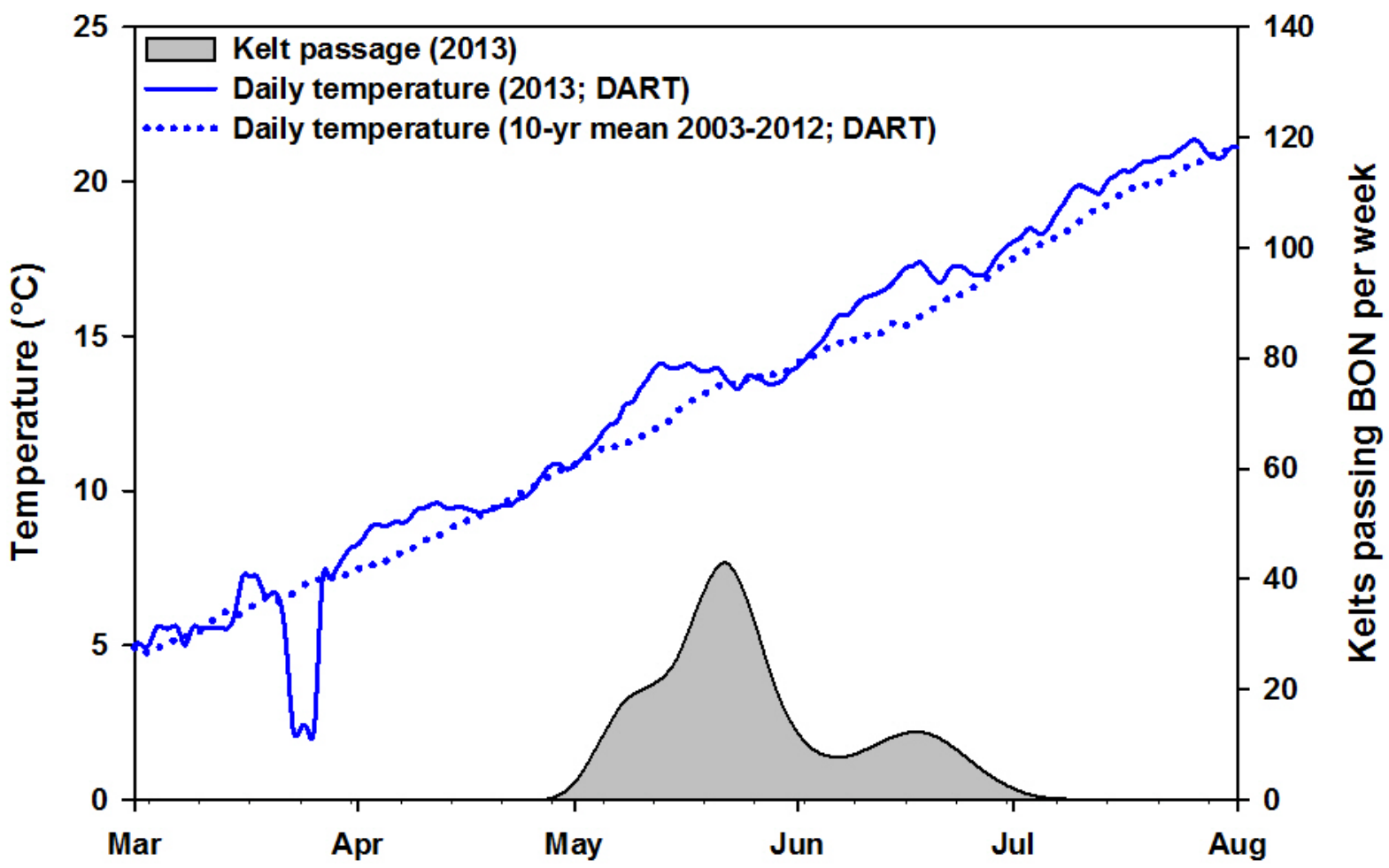

Figure E.4. Average daily forebay temperature $\left({ }^{\circ} \mathrm{C}\right)$ observed at Bonneville Dam (BON) from 1 March to 1 August 2013, with the 10-year average. Also shown are the numbers of kelts per week (Sunday-Saturday) detected passing BON during the same time period. Reported temperatures are daily averages as recorded at forebay water quality monitoring stations. All temperature data were obtained from the DART website (Data Access in Real Time; http://www.cbr.washington.edu/dart/). 


\section{Appendix F}

Timing of Kelts Captured and Tagged at Tagging Sites 


\section{Appendix F}

\section{Timing of Kelts Captured and Tagged at Tagging Sites}

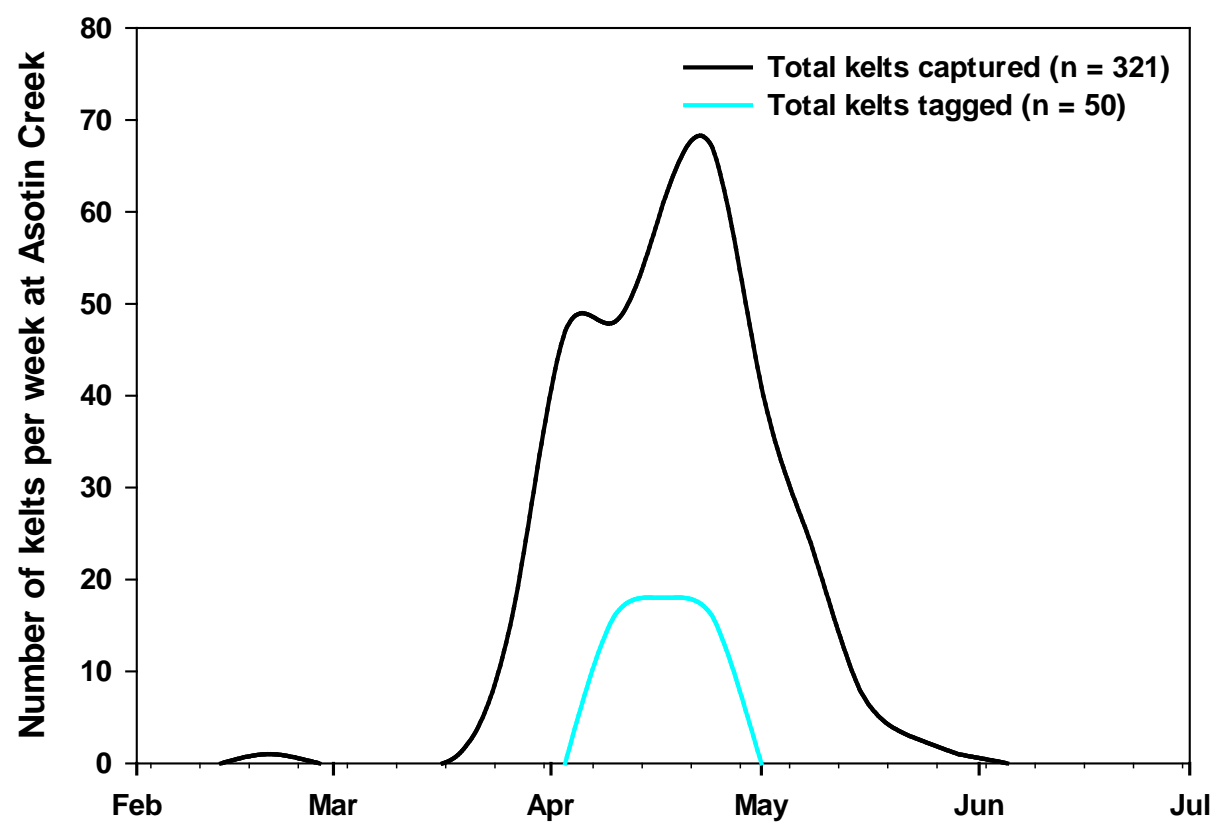

Figure F.1. Number of kelts surgically implanted with acoustic transmitters per week at Asotin Creek compared to the number of kelts captured by Washington Department of Fish and Wildlife at the weir in 2013. Kelts captured and tagged at the George Creek weir are also included in this figure. 


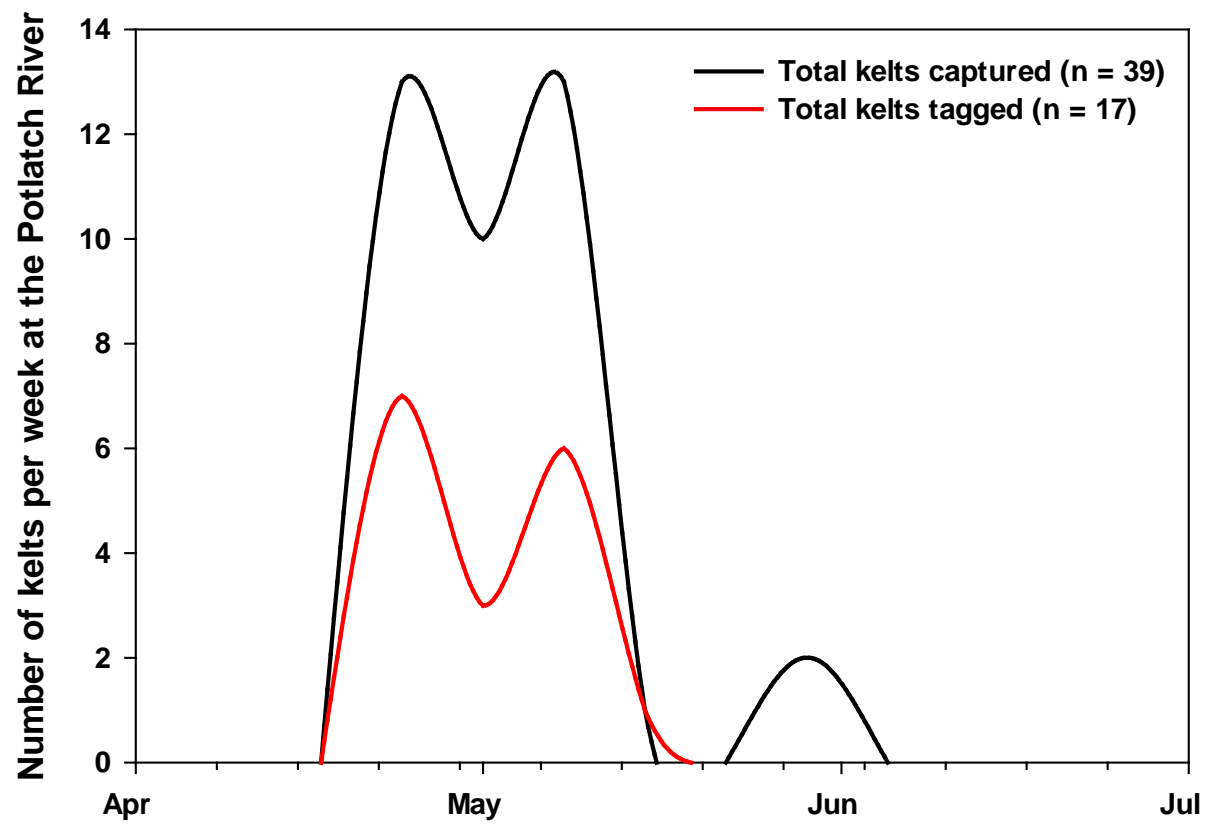

Figure F.2. The number of kelts surgically implanted with acoustic transmitters per week at the Potlatch River compared to the number of kelts captured by Idaho Department of Fish and Games at the weirs in 2013.

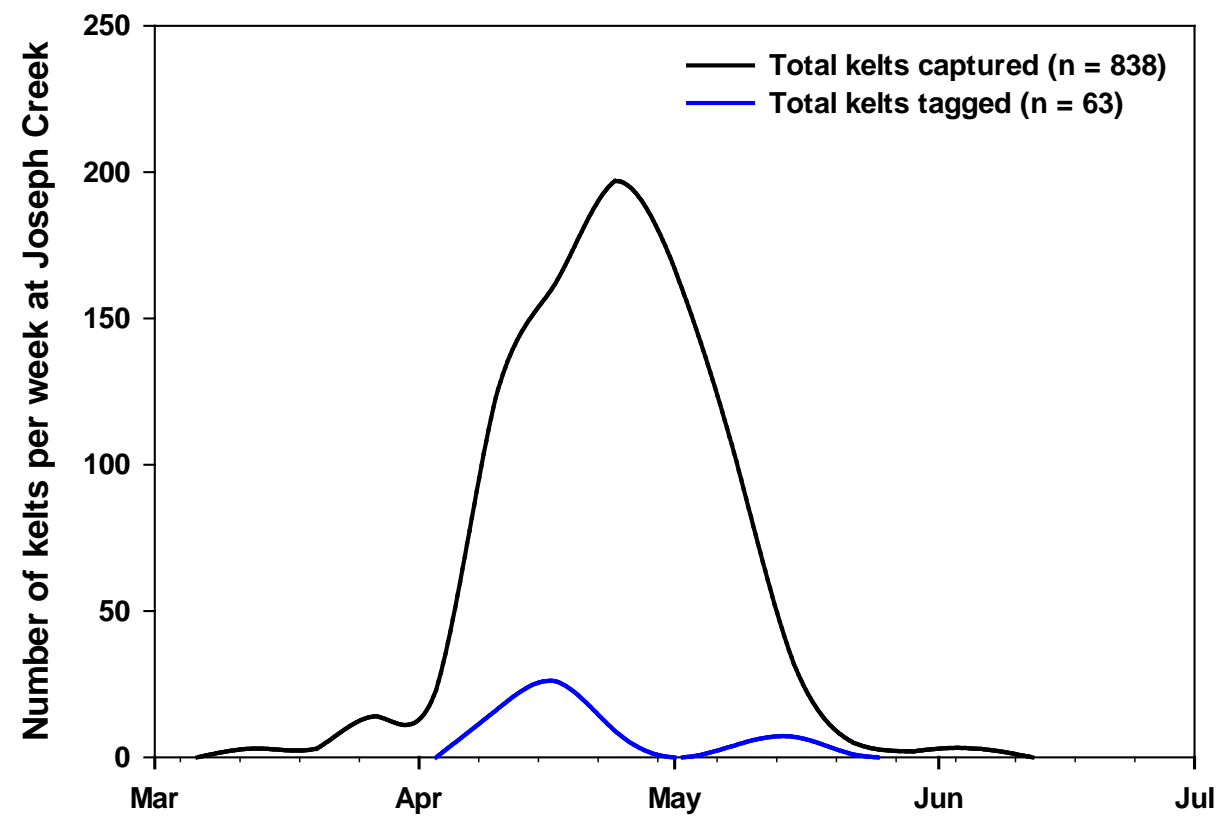

Figure F.3. Number of kelts surgically implanted with acoustic transmitters per week at Joseph Creek compared to the number of kelts captured by the Nez Perce Tribe at the weir in 2013. 


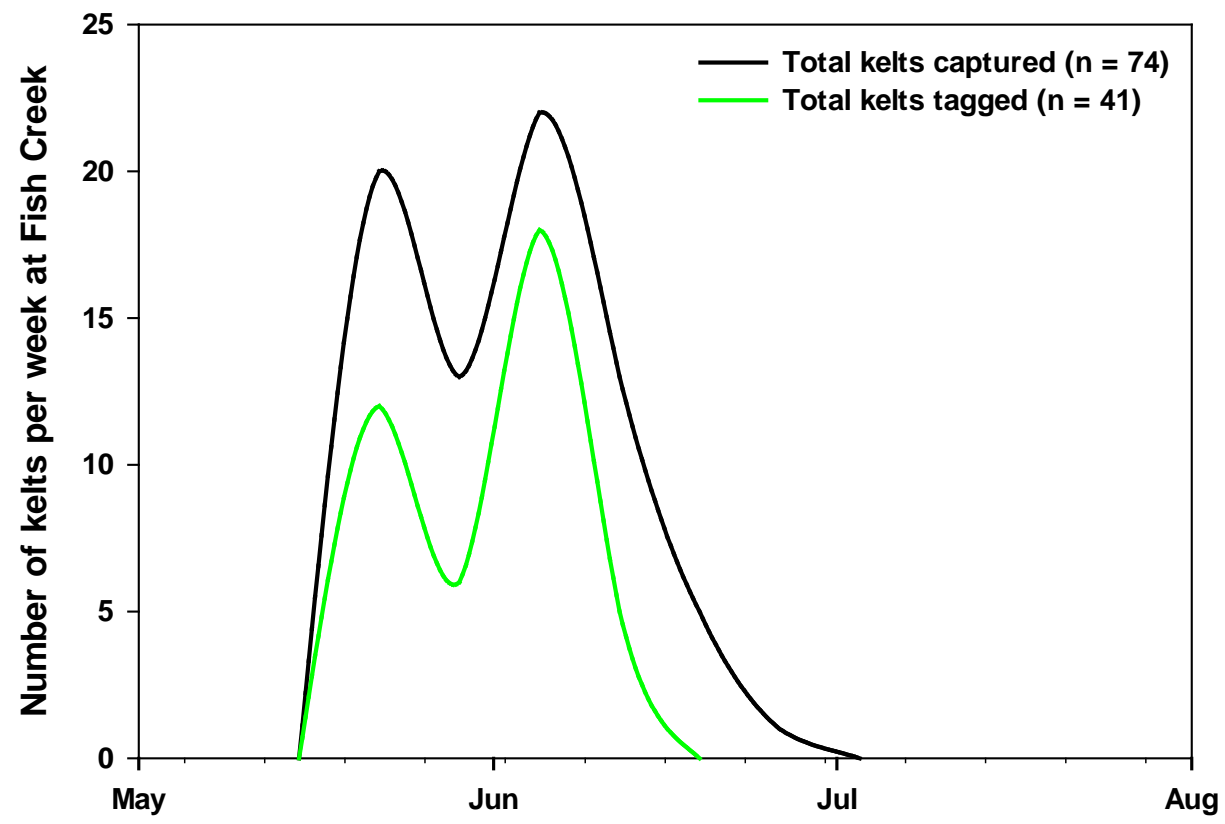

Figure F.4. Number of kelts surgically implanted with acoustic transmitters per week at Fish Creek compared to the number of kelts captured by Idaho Department of Fish and Game at the weir in 2013.

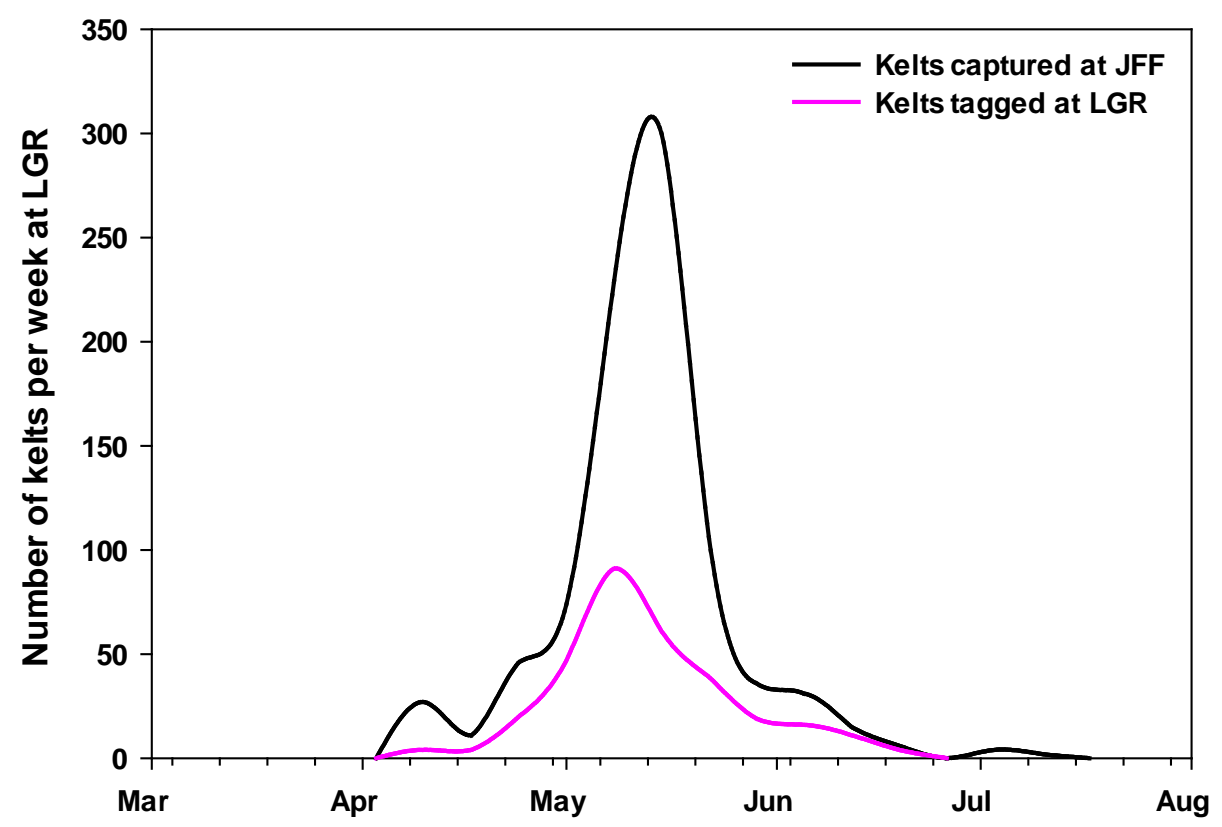

Figure F.5. Number of kelts tagged with acoustic transmitters at Lower Granite Dam (LGR) per week (gray) compared to the total number of steelhead kelts per week captured at the LGR Juvenile Fish Facility (JFF) separator (green) between 1 March and 1 August 2013. 


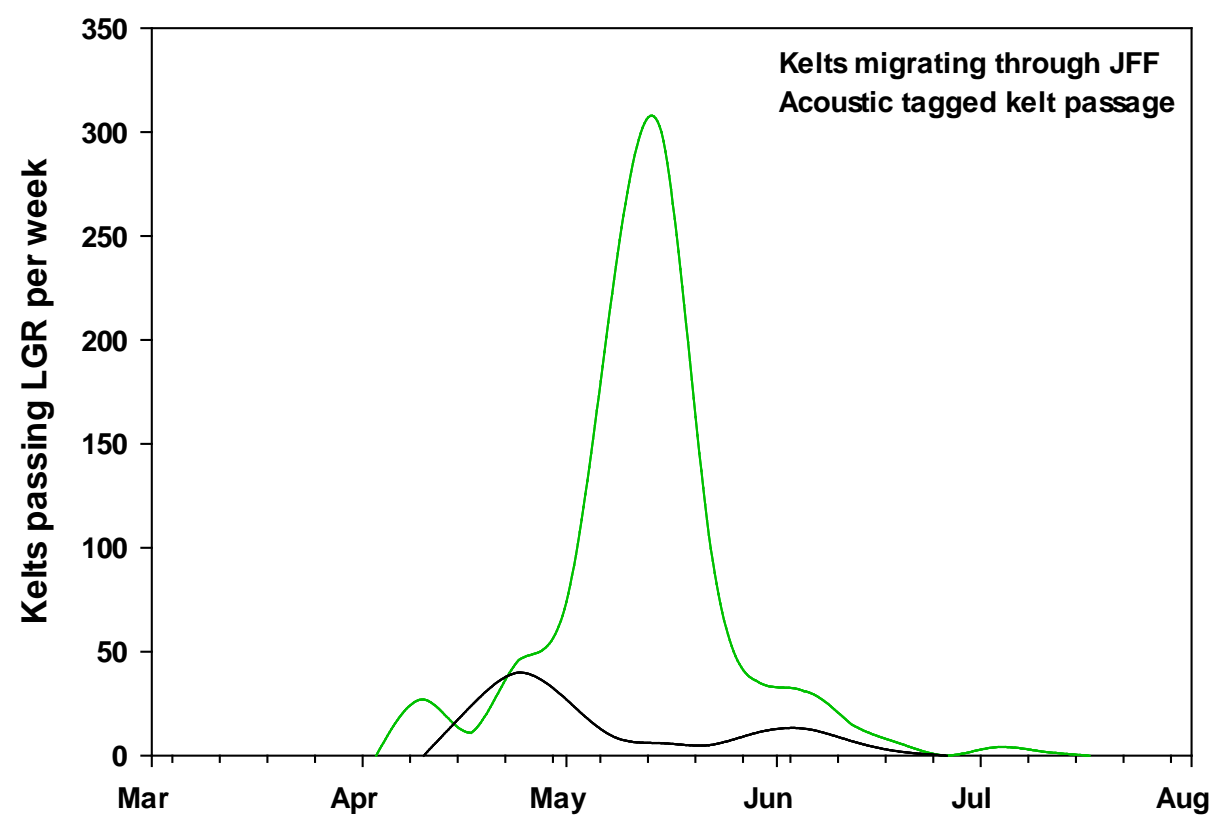

Figure F.6. Number of tagged kelts from tributary sites (gray) that passed Lower Granite Dam (LGR) per week compared to the total number of steelhead kelts captured per week at the LGR Juvenile Fish Facility (JFF) separator (green) between 1 March and 1 August 2013.

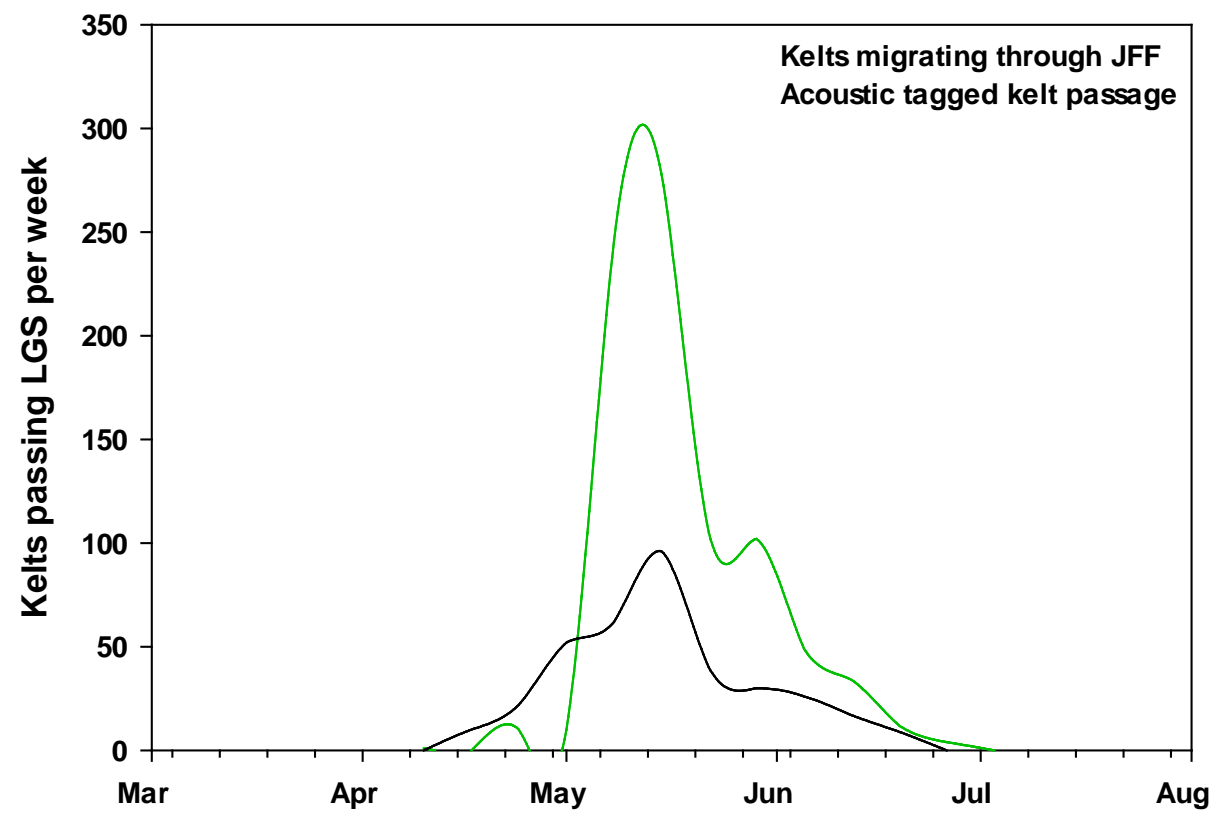

Figure F.7. Number of tagged kelts that passed Little Goose Dam (LGS) per week (gray) compared to the total number of steelhead kelts captured per week at the LGS Juvenile Fish Facility (JFF) separator (green) between 1 March and 1 August 2013. 


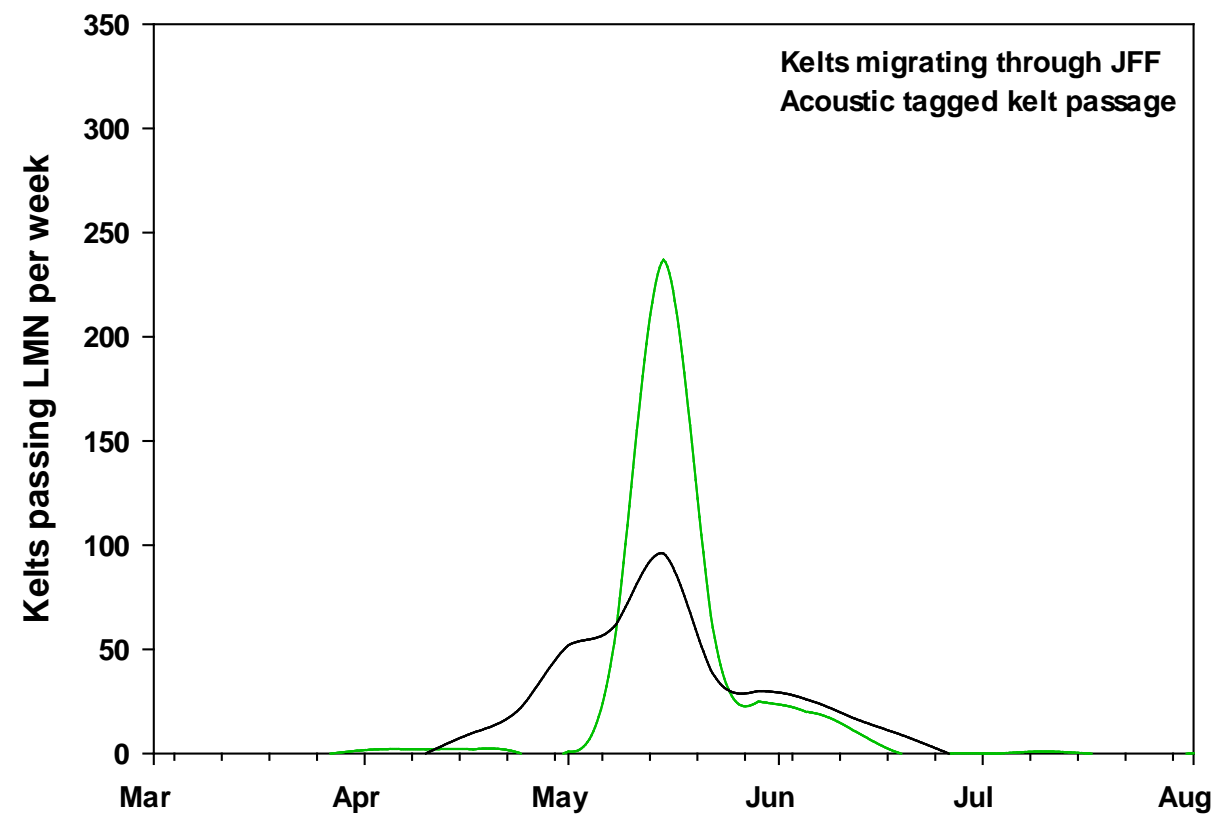

Figure F.8. Number of tagged kelts that passed Lower Monumental Dam (LMN) per week (gray) compared to the total number of steelhead kelts captured per week at the LMN Juvenile Fish Facility (JFF) separator (green) between 1 March and 1 August 2013. 
Appendix G

Juvenile Salmon Acoustic Telemetry System Performance 


\section{Appendix G}

\section{Juvenile Salmon Acoustic Telemetry System Performance}

Table G.1. Detection probabilities ( \pm SE) of steelhead kelts implanted with acoustic transmitters on the cabled receiver arrays at Lower Granite, Little Goose and Lower Monumental dams in 2013.

\begin{tabular}{lcc}
\hline \multicolumn{1}{c}{ Dam } & Array & Detection Probability (SE) \\
\hline Lower Granite & D1CR695 & $1.000(0.000)$ \\
Little Goose & D2CR635 & $0.997(0.003)$ \\
Lower Monumental & D3CR589 & $1.000(0.000)$ \\
\hline
\end{tabular}

Table G.2. Detection probabilities $( \pm$ SE) of steelhead kelts implanted with acoustic transmitters on the autonomous receiver arrays throughout the Federal Columbia River Power System in 2013 that were used to estimate survival.

\begin{tabular}{cc}
\hline Array & Detection Probability (SE) \\
\hline A1CR743 & $1.000(0.000)$ \\
A2CR696 & $0.992(0.008)$ \\
A4CR636 & $1.000(0.000)$ \\
A6CR602 & $0.997(0.003)$ \\
A7CR590 & $1.000(0.000)$ \\
A9CR562 & $1.000(0.000)$ \\
A10CR539 & $1.000(0.000)$ \\
A11CR525 & $1.000(0.000)$ \\
A12CR236 & $1.000(0.000)$ \\
\hline
\end{tabular}


Table G.3. Percentage of steelhead kelts implanted with acoustic transmitters detected on multiple autonomous receivers at each array deployed in the Federal Columbia River Power System in 2013.

\begin{tabular}{|c|c|c|c|c|c|c|c|c|c|c|c|c|}
\hline \multirow[b]{2}{*}{ Array } & \multirow{2}{*}{$\begin{array}{c}\text { Total } \\
\text { Number of } \\
\text { Receivers }\end{array}$} & \multirow{2}{*}{$\begin{array}{c}\text { Total Number } \\
\text { of Tags } \\
\text { Detected }\end{array}$} & \multicolumn{10}{|c|}{ Number of Receivers that Detected Each Fish Within an Array } \\
\hline & & & 1 & 2 & 3 & 4 & 5 & 6 & 7 & 8 & 9 & 10 \\
\hline CR743 & 3 & 160 & 2.5 & 23.8 & 73.8 & - & - & - & - & - & - & - \\
\hline CR696 & 4 & 147 & 6.8 & 23.8 & 28.6 & 40.8 & - & - & - & - & - & - \\
\hline CR693 & 2 & 442 & 7.7 & 92.3 & - & - & - & - & - & - & - & - \\
\hline CR636 & 4 & 382 & 5.2 & 11.3 & 23.8 & 59.7 & - & - & - & - & - & - \\
\hline CR634 & 3 & 360 & 2.2 & 26.4 & 71.4 & - & - & - & - & - & - & - \\
\hline CR602 & 4 & 331 & 0.0 & 4.2 & 15.7 & 80.1 & - & - & - & - & - & - \\
\hline CR590 & 4 & 306 & 0.7 & 10.5 & 23.5 & 65.4 & - & - & - & - & - & - \\
\hline CR587 & 3 & 290 & 2.1 & 24.1 & 73.8 & - & - & - & - & - & - & - \\
\hline CR562 & 4 & 266 & 0.0 & 0.8 & 10.2 & 89.1 & - & - & - & - & - & - \\
\hline CR539 & 4 & 234 & 0.9 & 3.0 & 18.8 & 77.4 & - & - & - & - & - & - \\
\hline CR525 & 4 & 219 & 0.5 & 5.5 & 33.3 & 60.7 & - & - & - & - & - & - \\
\hline CR236 & 4 & 146 & 0.0 & 1.4 & 8.9 & 89.7 & - & - & - & - & - & - \\
\hline CR152 & 8 & 105 & 27.6 & 36.2 & 23.8 & 4.8 & 4.8 & 1.9 & 0.0 & 1.0 & - & - \\
\hline CR126 & 8 & 133 & 6.8 & 30.8 & 29.3 & 17.3 & 9.0 & 3.0 & 3.8 & 0.0 & - & - \\
\hline CR113 & 10 & 26 & 30.8 & 42.3 & 15.4 & 3.8 & 0.0 & 3.8 & 0.0 & 3.8 & 0.0 & 0.0 \\
\hline
\end{tabular}




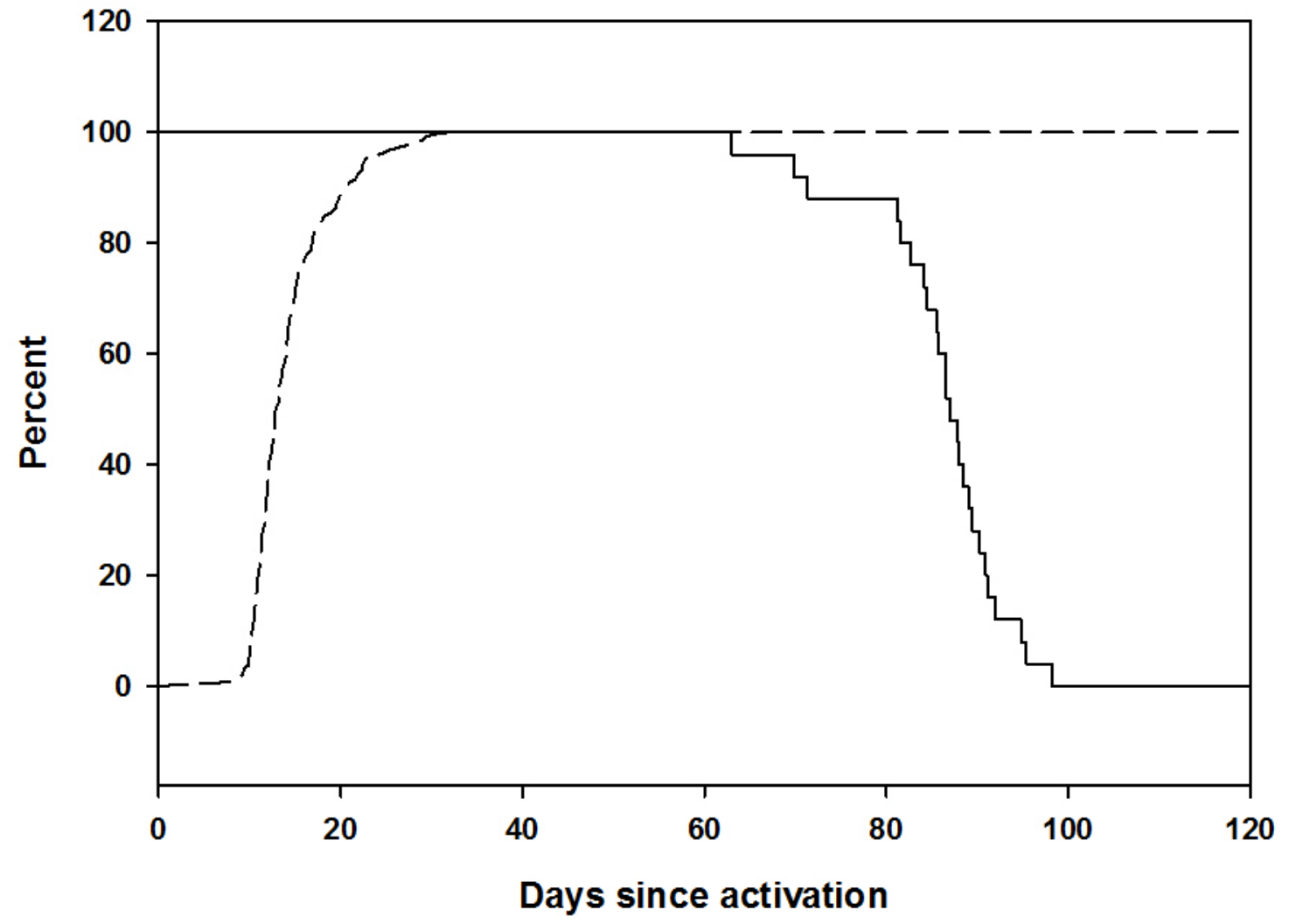

Figure G.1. Proportion of tag-life study tags that were transmitting (solid line) and the cumulative proportion of tagged steelhead kelts (dashed line) that arrived at the rkm 126 survivaldetection array as a function of days since tag activation. 


\section{Appendix $\mathrm{H}$}

Juvenile Salmon Acoustic Telemetry System-Tagged Kelts Dam Passage versus Flow 


\section{Appendix $\mathrm{H}$}

\section{Juvenile Salmon Acoustic Telemetry System-Tagged Kelts Dam Passage versus Flow}

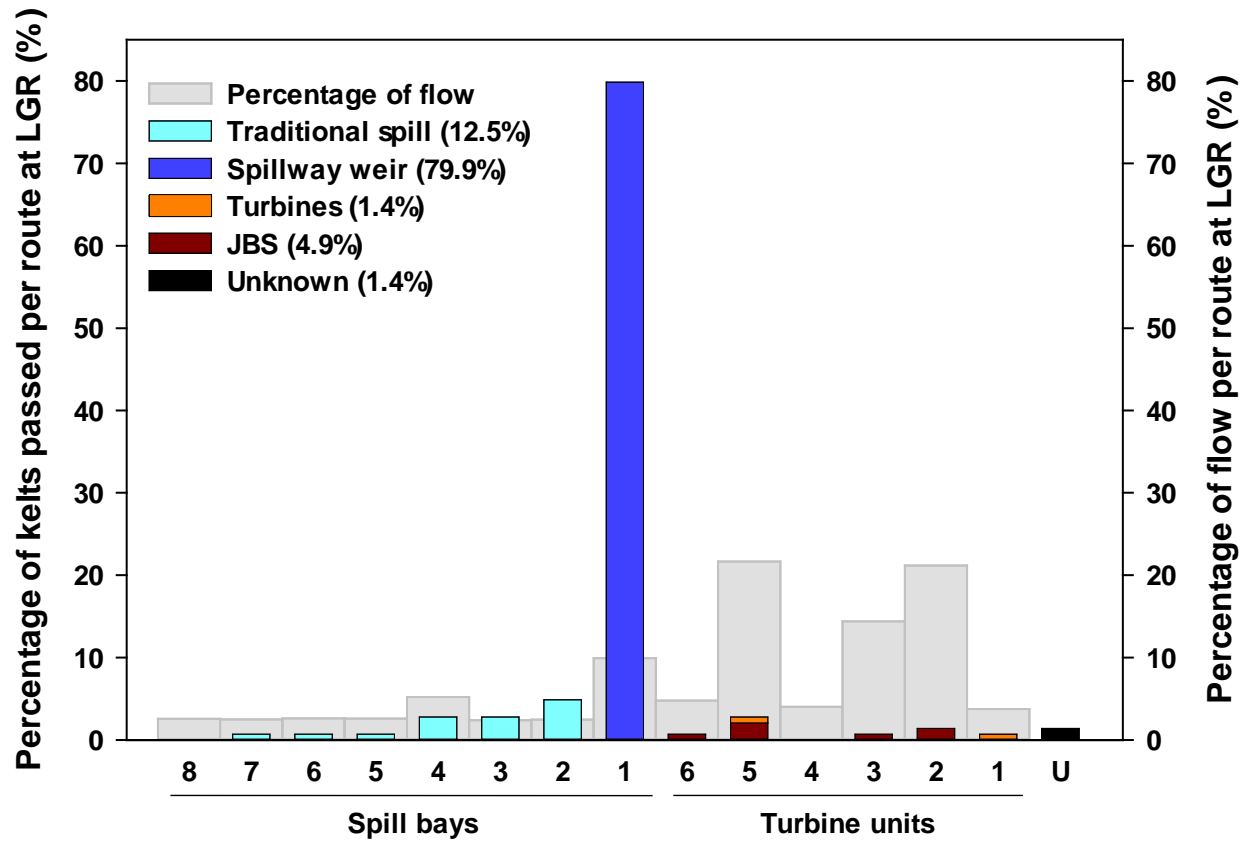

Figure H.1. Percentage of kelts that passed Lower Granite Dam (LGR) via each passage route (colored bars) and percentage of flow through each route (gray bars) during the period of tagged kelt passage at LGR (14 April 2013 to 17 June 2013). Passage routes are ordered from the north side of the river to the south side of the river. 


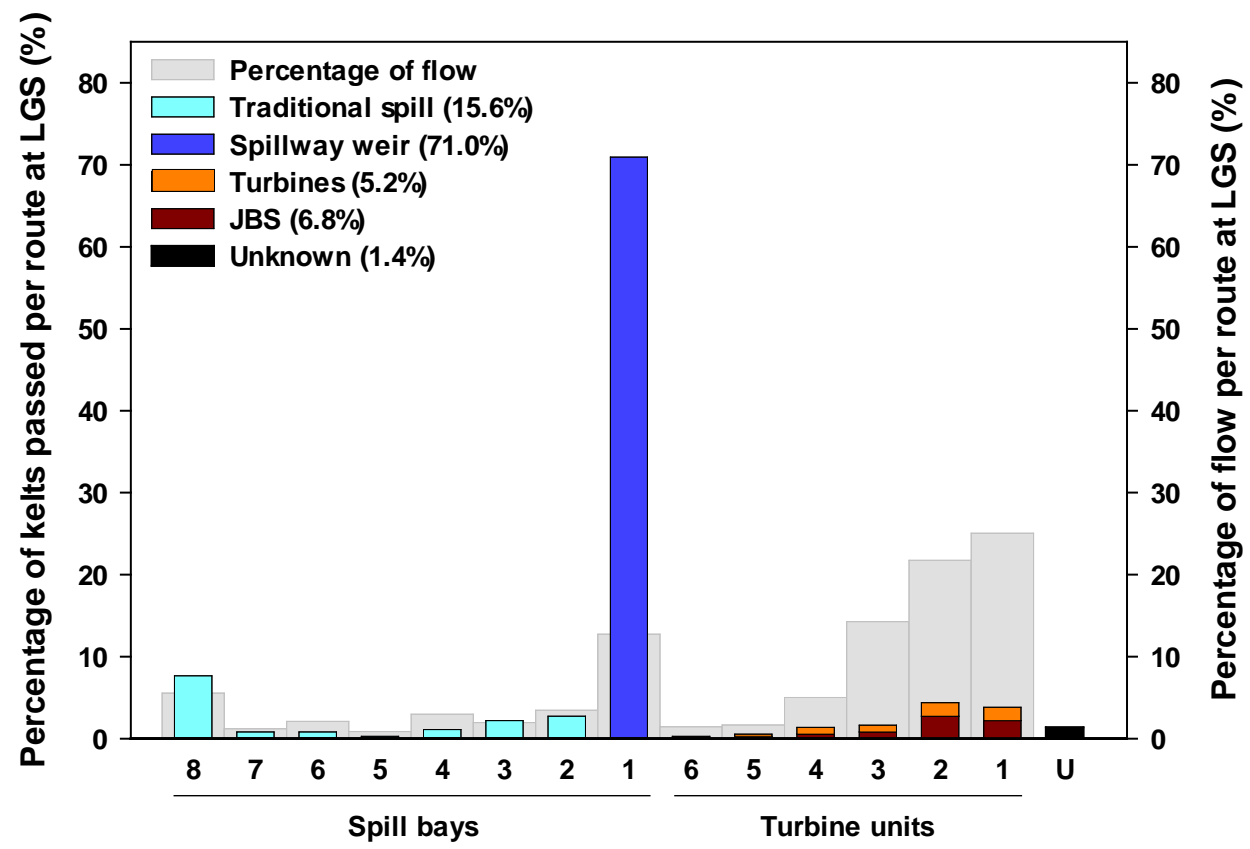

Figure H.2. Percentage of kelts that passed Little Goose Dam (LGS) via each passage route (colored bars) and percentage of flow through each route (gray bars) during the period of tagged kelt passage at LGS (17 April 2013 to 22 June 2013). Passage routes are ordered from the north side of the river to the south side of the river.

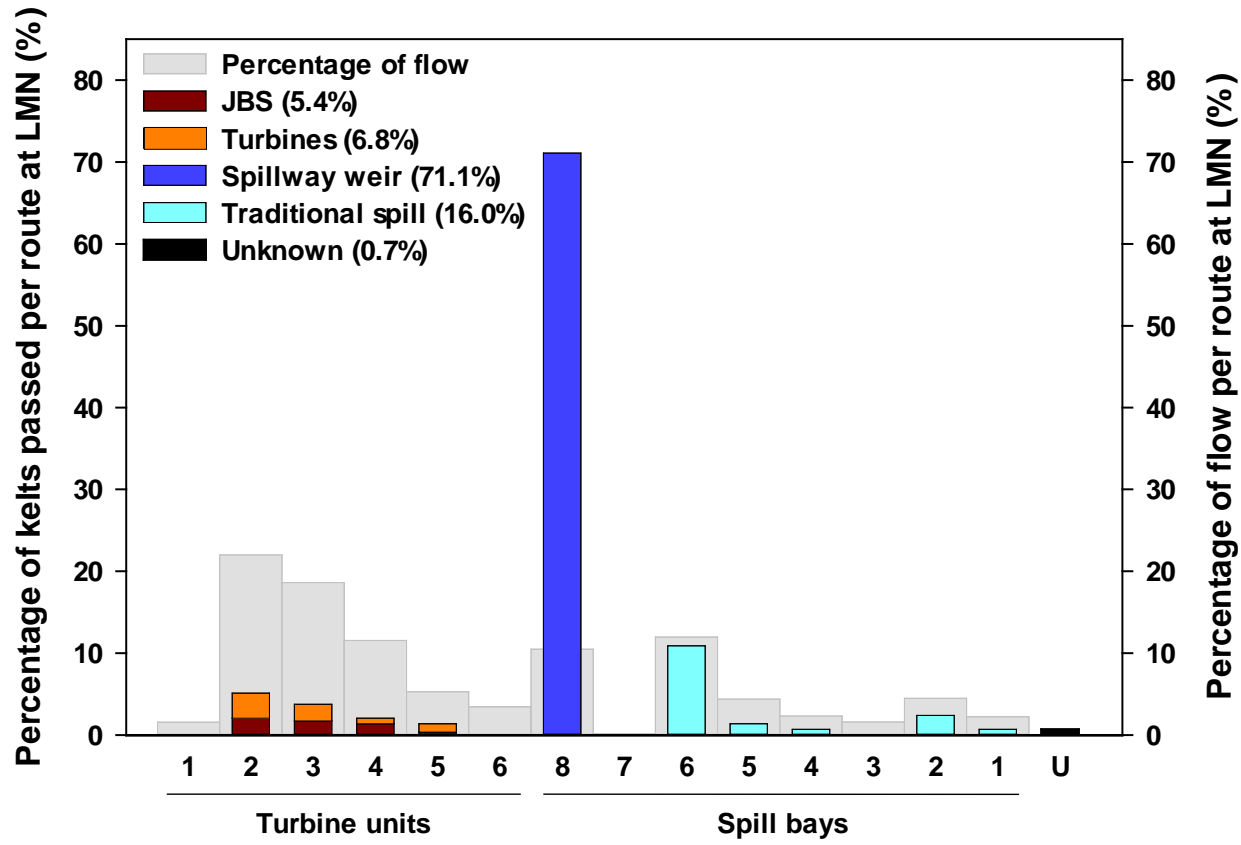

Figure H.3. Percentage of kelts that passed Lower Monumental Dam (LMN) via each passage route (colored bars) and percentage of flow through each route (gray bars) during the period of tagged kelt passage at LMN (19 April 2013 to 24 June 2013). Passage routes are ordered from the north side of the river to the south side of the river. 


\section{Appendix I}

\section{Diel Distribution and Dam Passage}




\section{Appendix I}

\section{Diel Distribution and Dam Passage}

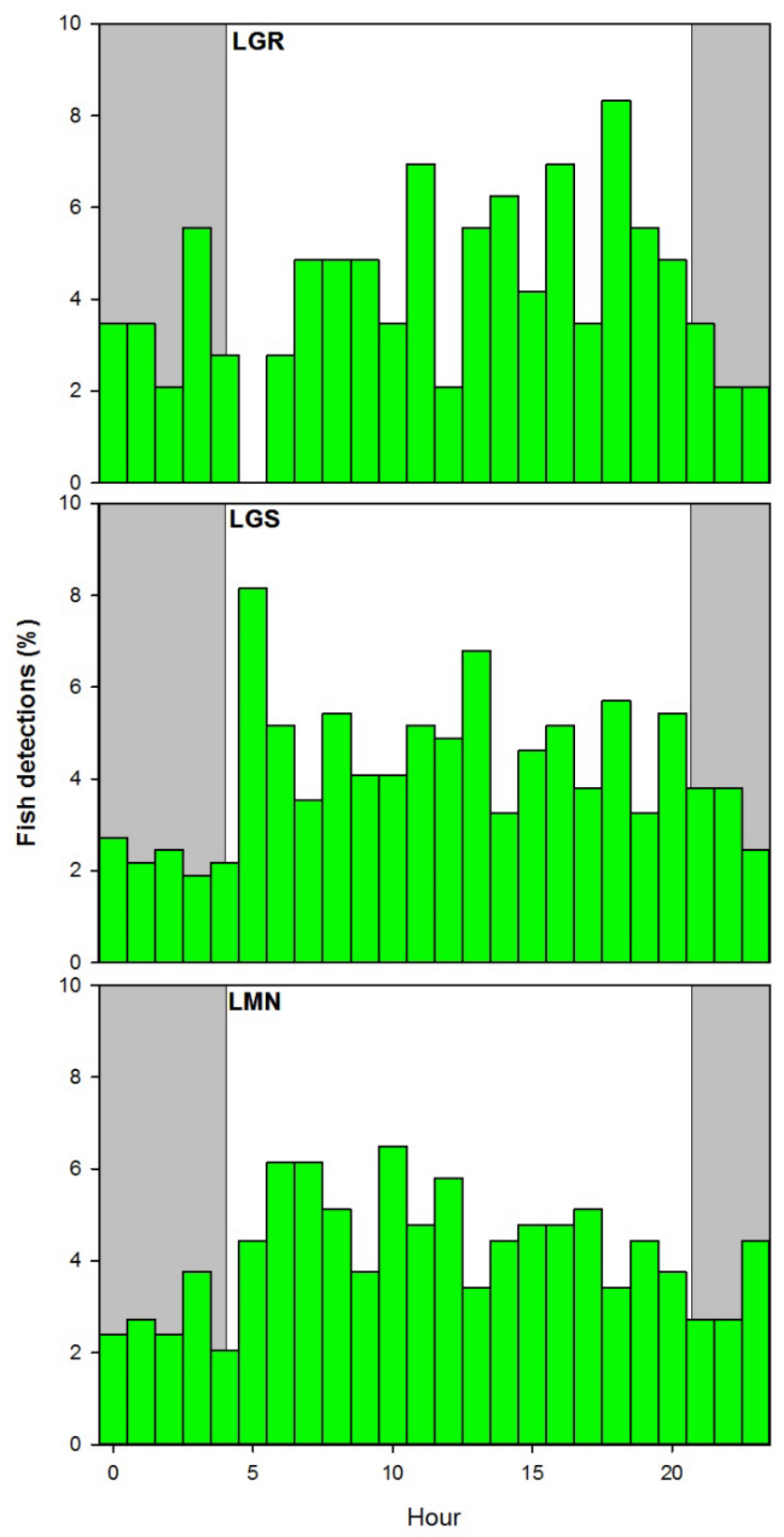

Figure I.1. Hourly distribution of steelhead kelt last detections at the cabled dam-face arrays at Lower Granite (LGR), Little Goose (LGS), and Lower Monumental (LMN) dams. Gray areas represent approximate hours of darkness. 


\section{Appendix J}

\section{Routes of Passage through Multiple Federal Columbia River Power System Dams}




\section{Appendix J}

\section{Routes of Passage through Multiple Federal Columbia River Power System Dams}

Table J.1. Routes of passage used by tagged kelts through Lower Granite (LGR), Little Goose (LGS), and Lower Monumental (LMN) dams in 2013. The number of individuals from each route combination that were detected below Bonneville Dam (BON) is also presented. JBS = juvenile bypass system.

\begin{tabular}{|c|c|c|c|c|c|c|}
\hline \multirow[b]{2}{*}{ LGR } & \multirow[b]{2}{*}{ LGS } & \multirow[b]{2}{*}{ LMN } & \multicolumn{2}{|c|}{$\begin{array}{l}\text { Passed through } \\
\text { route combination }\end{array}$} & \multicolumn{2}{|c|}{$\begin{array}{c}\text { Detected below } \\
\text { BON }\end{array}$} \\
\hline & & & $\mathrm{N}$ & $\%$ & $\mathrm{~N}$ & $\%$ \\
\hline Spillway weir & Spillway weir & Spillway weir & 28 & 6.6 & 12 & 42.9 \\
\hline Spillway weir & Spillway weir & Traditional spill & 9 & 2.1 & 6 & 66.7 \\
\hline Spillway weir & Spillway weir & JBS & 2 & 0.5 & 0 & 0.0 \\
\hline Spillway weir & Spillway weir & Turbine & 5 & 1.2 & 1 & 20.0 \\
\hline Spillway weir & Spillway weir & & 10 & 2.4 & 0 & 0.0 \\
\hline Spillway weir & Traditional spill & Spillway weir & 5 & 1.2 & 3 & 60.0 \\
\hline Spillway weir & Traditional spill & Traditional spill & 2 & 0.5 & 0 & 0.0 \\
\hline Spillway weir & Traditional spill & & 4 & 0.9 & 0 & 0.0 \\
\hline Spillway weir & Turbine & Spillway weir & 2 & 0.5 & 1 & 50.0 \\
\hline Spillway weir & Turbine & & 2 & 0.5 & 0 & 0.0 \\
\hline Spillway weir & & & 46 & 10.9 & 0 & 0.0 \\
\hline Traditional spill & Spillway weir & Spillway weir & 5 & 1.2 & 3 & 60.0 \\
\hline Traditional spill & Spillway weir & Traditional spill & 1 & 0.2 & 1 & 100.0 \\
\hline Traditional spill & Spillway weir & Turbine & 1 & 0.2 & 0 & 0.0 \\
\hline Traditional spill & Spillway weir & & 2 & 0.5 & 0 & 0.0 \\
\hline Traditional spill & Traditional spill & Traditional spill & 1 & 0.2 & 0 & 0.0 \\
\hline Traditional spill & Traditional spill & & 1 & 0.2 & 0 & 0.0 \\
\hline Traditional spill & & & 7 & 1.7 & 0 & 0.0 \\
\hline JBS & Spillway weir & Traditional spill & 1 & 0.2 & 1 & 100.0 \\
\hline JBS & Spillway weir & & 1 & 0.2 & 0 & 0.0 \\
\hline JBS & & & 5 & 1.2 & 0 & 0.0 \\
\hline Turbine & Traditional spill & & 1 & 0.2 & 0 & 0.0 \\
\hline Turbine & Turbine & Spillway weir & 1 & 0.2 & 0 & 0.0 \\
\hline & Spillway weir & Spillway weir & 127 & 30.1 & 67 & 52.8 \\
\hline & Spillway weir & Traditional spill & 21 & 5.0 & 8 & 38.1 \\
\hline & Spillway weir & JBS & 9 & 2.1 & 7 & 77.8 \\
\hline & Spillway weir & Turbine & 8 & 1.9 & 2 & 25.0 \\
\hline & Spillway weir & & 29 & 6.9 & 0 & 0.0 \\
\hline & Traditional spill & Spillway weir & 24 & 5.7 & 9 & 37.5 \\
\hline & Traditional spill & Traditional spill & 3 & 0.7 & 1 & 33.3 \\
\hline & Traditional spill & JBS & 3 & 0.7 & 1 & 33.3 \\
\hline
\end{tabular}


Table J.1 (contd)

\begin{tabular}{|c|c|c|c|c|c|c|}
\hline \multirow[b]{2}{*}{ LGR } & \multirow[b]{2}{*}{ LGS } & \multirow[b]{2}{*}{$\mathrm{LMN}$} & \multicolumn{2}{|c|}{$\begin{array}{l}\text { Passed through } \\
\text { route combination }\end{array}$} & \multicolumn{2}{|c|}{$\begin{array}{c}\text { Detected below } \\
\text { BON }\end{array}$} \\
\hline & & & $\mathrm{N}$ & $\%$ & $\mathrm{~N}$ & $\%$ \\
\hline & Traditional spill & Turbine & 1 & 0.2 & 0 & 0.0 \\
\hline & Traditional spill & & 13 & 3.1 & 0 & 0.0 \\
\hline & JBS & Spillway weir & 12 & 2.8 & 5 & 41.7 \\
\hline & JBS & Traditional spill & 3 & 0.7 & 1 & 33.3 \\
\hline & JBS & Turbine & 3 & 0.7 & 0 & 0.0 \\
\hline & JBS & & 7 & 1.7 & 0 & 0.0 \\
\hline & Turbine & Spillway weir & 4 & 0.9 & 3 & 75.0 \\
\hline & Turbine & Traditional spill & 5 & 1.2 & 3 & 60.0 \\
\hline & Turbine & JBS & 2 & 0.5 & 0 & 0.0 \\
\hline & Turbine & Turbine & 1 & 0.2 & 0 & 0.0 \\
\hline & Turbine & & 2 & 0.5 & 0 & 0.0 \\
\hline & & Spillway weir & 1 & 0.2 & 1 & 100.0 \\
\hline & & Traditional spill & 1 & 0.2 & 0 & 0.0 \\
\hline & & Turbine & 1 & 0.2 & 0 & 0.0 \\
\hline
\end{tabular}


Appendix K

Return Rates 


\section{Appendix K}

\section{Return Rates}

PTAGIS (www.ptagis.org) was queried for the PIT-tag detection histories of all steelhead kelts tagged in the 2012 and 2013 acoustic telemetry studies. These detection histories were examined to determine if any kelts migrated upstream from the ocean through fish ladders since 31 March 2014 when this report was finalized. At the time of this report revision (15 December 2014), a total of five kelts that were tagged in 2012 or 2013 were detected moving back upstream in the FCRPS.

A total of four of the 324 (1.2\%) steelhead kelts that were tagged with acoustic transmitters in 2012 were detected making upstream migrations in the summer and fall of 2013 (Table K.1). One of the returning fish, a female, was tagged in 2012 at the Joseph Creek weir, and the remaining three were tagged at LGR. The kelt tagged at Joseph Creek was detected in August 2013 at the PIT-tag detection array near the mouth of the Deschutes River (at river kilometer 328). The Deschutes River is a tributary of the Columbia River that Snake River steelhead commonly use as a thermal refuge during summer months because it generally has cooler water temperatures than the Columbia River (High et al. 2006). This fish was detected moving upstream through the FCRPS and was detected in November 2013 as it passed LGR. The other three fish (two females and one male) were detected moving upstream through the FCRPS and into the LGR adult fish ladder in August (female) and September (male and female) 2013. The female detected in the LGR adult fish ladder in August was detected in Big Sheep Creek (a tributary of the Lower Imnaha River) in April 2014. The female detected in the LGR adult fish ladder in September was detected in Joseph Creek in March 2014.

Only one of the 487 (0.2\%) kelts that were tagged with acoustic transmitters in 2013 was detected making an upstream migration in the summer of 2014 (Table K.1). This female kelt was tagged in April 2013 at the Asotin Creek weir. She was subsequently detected in the Bonneville Dam (BON) adult fish ladder in August 2014.

A total of five of the 811 (0.6\%) steelhead kelts that were tagged in the 2012 and 2013 studies returned to BON. All of these fish were in good condition at the time of tagging, had an intact adipose fin, and displayed a skip spawning life history strategy. Generally, fish left the river in the spring/early summer spent approximately one year in the ocean, and were detected in the BON adult fish ladder in the summer of the following year. There were two fish that returned to a tributary upstream of LGR. These fish were detected at LGR in August - November, and were detected in the tributary the following spring.

The passage routes that returning fish used during their downstream passage in 2012 and 2013 were examined to determine if any trends were present. Although trends were observed, low sample sizes preclude any statistical analysis, and all trends should be interpreted cautiously. Overall, the kelts that returned tended to use the most commonly used passage routes at all dams in the FCRPS during their downstream migration (Table K.2). For example, 75 to 100\% of the fish from the 2012 cohort that returned used the spillway weir routes at LGS and LMN. During downstream passage, $60.8 \%$ and 68.0\% of kelts in the 2012 cohort used the spillway weir route at LGS and LMN, respectively. Additionally, none of the fish from the 2012 and 2013 studies that returned were determined to have passed through available turbine routes at FCRPS dams. 
Overall, annual return rates for fish tagged in the 2012 and 2013 acoustic telemetry studies were within or lower than recent Snake River steelhead annual iteroparity estimates (0.5\% to 1.2\%; Keefer et al. 2008). The annual return rates of kelts from this study were lower than pre-dam repeat spawner rates (2\%; Long and Griffin 1937). Based on this information, it is evident that further research is needed to understand the factors that affect iteroparity rates and the steps that can be taken to improve such rates as is called for in the Reasonable and Prudent Alternative 33 of the 2008 Biological Opinion (NOAA 2008). The factors that influence in-river and dam passage survival rates are currently being investigated by PNNL; the goal of that study is to shed some light on the dam operations and abiotic conditions that are related to passage and survival of steelhead kelts at FCRPS dams (Harnish et al. In Draft). Additionally, comparison of the iteroparity rates of steelhead kelts that are included in the kelt reconditioning program with kelts that are left in the river to migrate downstream may be helpful for focusing future efforts to improve Snake River steelhead iteroparity rates. 
Table K.1. Tagging date, location, and river kilometer (rkm), sex, condition at tagging, adipose fin status, length at tagging, and most recent detection information for steelhead kelts that were detected moving upstream in the Columbia and Snake rivers. PIT = Passive integrated transponder, LGR = Lower Granite Dam, BON = Bonneville Dam

\begin{tabular}{|c|c|c|c|c|c|c|c|c|c|c|}
\hline \multirow[b]{2}{*}{ PIT Tag Number } & \multicolumn{3}{|c|}{ Tagging } & \multirow[b]{2}{*}{ Sex } & \multirow{2}{*}{$\begin{array}{c}\text { Condition } \\
\text { at Tagging }\end{array}$} & \multirow{2}{*}{$\begin{array}{l}\text { Adipose } \\
\text { Clipped }\end{array}$} & \multirow{2}{*}{$\begin{array}{l}\text { Length } \\
(\mathrm{cm})\end{array}$} & \multicolumn{3}{|c|}{ Most Recent Detection } \\
\hline & Date & Location & $\mathrm{rkm}$ & & & & & Date & Location & rkm \\
\hline 3D9.1C2D48165B & $5 / 1 / 2012$ & Joseph Creek & 800 & $\mathrm{~F}$ & Good & No & 57.8 & $11 / 20 / 2013$ & LGR Adult Fish Ladder & 695 \\
\hline 3D9.1BF25EA11A & $4 / 24 / 2012$ & LGR Bypass & 695 & $\mathrm{~F}$ & Good & No & 53.0 & $3 / 9 / 2014$ & Joseph Creek & 800 \\
\hline 3D9.1BF253949F & $5 / 11 / 2012$ & LGR Bypass & 695 & M & Good & No & 56.0 & $9 / 20 / 2013$ & LGR Adult Fish Ladder & 695 \\
\hline 3D9.1C2D97F750 & $5 / 24 / 2012$ & LGR Bypass & 695 & $\mathrm{~F}$ & Good & No & 56.0 & $4 / 27 / 2014$ & Big Sheep Creek & 868 \\
\hline 3D9.1C2DCE8A95 & $4 / 22 / 2013$ & Asotin Creek & 760 & $\mathrm{~F}$ & Good & No & 67.9 & 8/9/2014 & BON Adult Fish Ladder & 234 \\
\hline
\end{tabular}

Table K.2. Downstream passage route information for steelhead kelts that were detected moving upstream through the Columbia and Snake rivers. LGR = Lower Granite Dam, LGS = Little Goose Dam, LMN = Lower Monumental Dam, MCN = McNary Dam, JDA = John Day Dam, TDA = The Dalles Dam, BON = Bonneville Dam.

\begin{tabular}{|c|c|c|c|c|c|c|c|}
\hline \multirow[b]{2}{*}{ PIT Tag Number } & \multicolumn{7}{|c|}{ Route of Passage } \\
\hline & LGR & LGS & LMN & MCN & JDA & TDA & $\mathrm{BON}$ \\
\hline 3D9.1C2D48165B & Spillway weir & Spillway weir & Spillway weir & $\begin{array}{c}\text { Traditional } \\
\text { spillway }\end{array}$ & Spillway weir & $\begin{array}{c}\text { Traditional } \\
\text { spillway }\end{array}$ & $\begin{array}{c}\text { Traditional } \\
\text { spillway }\end{array}$ \\
\hline 3D9.1BF25EA11A & JBS* & JBS & Spillway weir & $\begin{array}{c}\text { Traditional } \\
\text { spillway }\end{array}$ & $\begin{array}{c}\text { Traditional } \\
\text { spillway }\end{array}$ & $\begin{array}{c}\text { Traditional } \\
\text { spillway }\end{array}$ & $\begin{array}{c}\text { Traditional } \\
\text { spillway }\end{array}$ \\
\hline 3D9.1BF253949F & JBS* & Spillway weir & Spillway weir & $\begin{array}{c}\text { Traditional } \\
\text { spillway }\end{array}$ & Spillway weir & $\begin{array}{c}\text { Traditional } \\
\text { spillway }\end{array}$ & $\begin{array}{c}\text { Traditional } \\
\text { spillway }\end{array}$ \\
\hline 3D9.1C2D97F750 & JBS* & Spillway weir & Spillway weir & Spillway weir & Spillway weir & $\begin{array}{c}\text { Traditional } \\
\text { spillway }\end{array}$ & $\begin{array}{c}\text { Traditional } \\
\text { spillway }\end{array}$ \\
\hline 3D9.1C2DCE8A95 & Spillway weir & Spillway weir & Spillway weir & - & - & - & JBS \\
\hline
\end{tabular}

* Fish passed through the JBS and were subsequently tagged for this study 


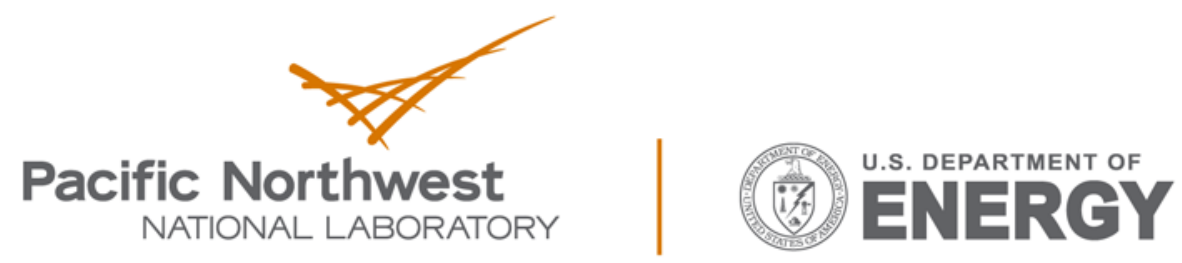

Proudly Operated by Battelle Since 1965

902 Battelle Boulevard

P.O. Box 999

Richland, WA 99352

1-888-375-PNNL (7665)

www.pnnl.gov 